This publication has been superseded by ODPं Technical Note 30 :

http://www-odp.tamu.edu/publications/tnotes/tn30/INDEX.HTM

\title{
SHIPBOARD ORGANIC GEOCHEMISTRY
}

ON

\section{JOIDES RESOLUTION}

Kay-Christian Emeis ocean Drilling Program

Texas A\&M University College Station, TX 77843-3469
Keith A. Kvenvolden

U.S. Geological Survey M/S 999 345 Middlefield Road Menlo Park, CA 94025

OCEAN DRILLING PROGRAM

TEXAS A\&M UNIVERSITY

TECHNICAL NOTE

NUMBER 7

OCTOBER 1986

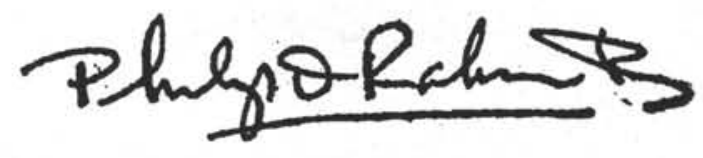

Philip D. Rabinowitz

Director
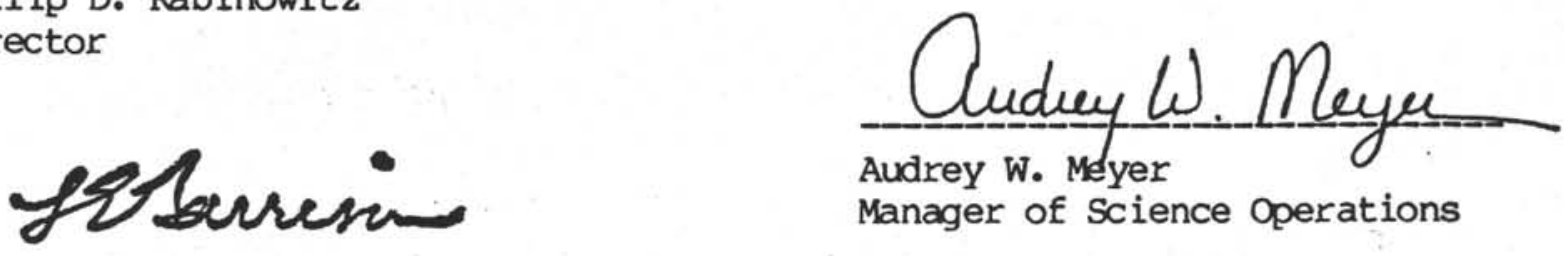

Louis E. Garrison

Deputy Director 
Material in this publication may be copied without restraint for library, abstract service, educational or personal research purposes; however, republication of any portion requires the written consent of the Director, Ocean Drilling Program, Texas A\&M University, College Station, Texas 77843-3469, as well as appropriate acknowledgement of this source.

\section{Technical Note No. 7}

First Printing 1986

\section{Distribution}

Copies of this publication may be obtained from the Director, Ocean Drilling Program, Texas A\&M University, College Station, Texas 77843-3469. In some cases, orders for copies may require a payment for postage and handling.

\section{DISCLAIMER}

This publicalion was prepared by the Ocean Drilling Program, Texas A\&M University, as an account of work performed under the international Ocean Drilıing $r_{\text {z.ogram }}$ which is managed by Joint Oceanographic Institutions, Inc., under contract with the National Science Foundation. Funding for the program is provided by the following agencies:

Department of Energy, Mines and Resources (Canada) Deutsche Forschungsgemeinschaft (Federal Republic of Germany)

Institut Francais de Recherche pour l'Exploitation de la Mer (France) Ocean Research Institute of the University of Tokyo (Japan)

National Science Foundation (United States) Natural Environment Research Council (United Kingdom)

European Science Foundation Consortium for the Ocean Drilling Program

(Belgium, Denmark, Finland, Iceland, Italy, Greece, the Netherlands, Norway, Spain, Sweden, Switzerland and Turkey)

Any opinions, findings and conclusions or recommendations expressed in this publication are those of the author(s) and do not necessarily reflect the views of the National Science Foundation, the participating agencies, Joint Oceanographic Institutions, Inc., or Texas A\&M University Research Foundation. 
"This will revolutionize geochemistry at sea," was the reaction of Dennis Graham, a chemistry technician with a long history in DSDP chemistry programs, after working--on the shakedown cruise, Leg 100 of the Ocean Drilling Program--in the Chemistry Laboratory of JOIDES Resolution. One of the main prerequisites for scientific advancement has always been the access to modern instrumentation, and the geochemical veteran cited above acknowledged the effort of ODP to provide a state-of-the-art laboratory for chemical work at the locus of interest: the drill site. Surpassing the main concern of shipboard organic geochemistry in previous phases of scientific ocean drilling, i.e. safety monitoring for hydrocarbons, geochemists onboard JOIDES Resolution are now able to analyze almost every property of sediments and rocks, ephemeral and resident, according to the modern analytical and data handling standards.

The following Technical Note is one of a series of three on geochemistry onboard JOIDES Resolution + ). The demand for a concise description of tasks and supporting infrastructure for geochemical work onboard ship was the immediate reason for writing this series. Equally important was the desire to standardize methodology and to document geochemical work performed in the previous phases of scientific ocean drilling. They are intended to provide a guideline for shipboard geochemists, in order to facilitate their various duties.

The chemistry laboratory owes its tremendous potential to the advic? and help of numerous individuals, who provided invaluable assistance in design and set-up. ODP acknowledges, in particular, the efforts of Drs. J.H. Brooks and M.C. Kennicutt II (Oceanography Department, Texas A\&M University) in the planning stage; of Bradley Julson and Dennis Graham (ODP) for their activities toward setting up the laboratory in its present great shape; of Drs. Keith Kvenvolden (U.S.G.S., Menlo Park), Joris Gieskes (Scripps Institution of Oceanography), Kay Emeis (ODP), Mr. Thomas McDonald (Oceanography Dept., TAMU), and Ms. Gail Peretsman (ODP), who were responsible for setting up the methods and procedures for the chemistry laboratories and writing these reports; and of Ms. Katie Sigler, Ms. Gail Peretsman, Ms. Tamara Frank, Mr. Matt Mefferd, Mr. Larry Bernstein, and Mr. Bradley Julson, for their roles in the maintenance and operation of the chemistry equipment at sea. Without the efforts of all of the above persons, the chemistry at sea program would not have reached its present highly successful state.

+) Gieskes, J.M., and Peretsman, G., 1986. Water Chemistry Procedures aboard JOIDES Resolution. ODP Technical Note \#5. Kvenvolden, K.A., and McDonald, T.J., 1986. Organic Geochemistry on the JOIDES Resolution -- An Assay. ODP Technical Note \#6.

Emeis, K.-C., and Kvenvolden, K.A., 1986. Shipboard Organic Geochemistry on JOIDES Resolution. ODP Technical Note \#7.

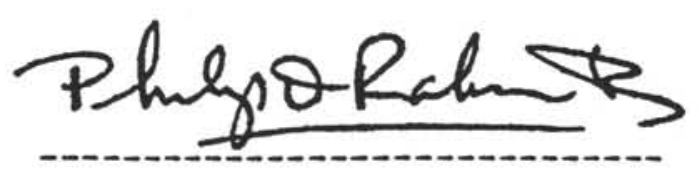

Philip D. Rabinowitz, Director 
TABLE OF CONTENTS

Page

I. Introduction $\ldots \ldots \ldots \ldots \ldots \ldots \ldots \ldots \ldots \ldots \ldots \ldots \ldots \ldots \ldots \ldots \ldots \ldots \ldots \ldots \ldots$

A. Duties of Shipboard Organic Geochemist ........... 1

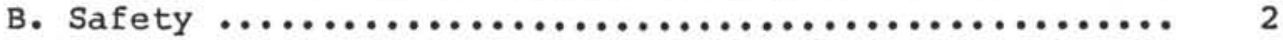

C. Resources Available to the Organic Analyst ........ 2

D. Instrumentation for Organic Geochemistry ......... 3

II. Gas and $\mathrm{Oil}$ Monitoring Procedures ................... 7

II. Sampling and Analysis ......................... 11

A. Routine Sampling Program ..................... 11

1. Geochemical Parameters from Routine Sampling .... 11

2. Sampling Scheme ....................... 12

B. Frozen Organic Geochemistry Samples ............ 12

C. Routine Analyses for Organic Geochemistry ......... 19

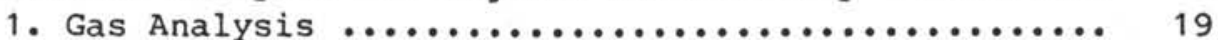

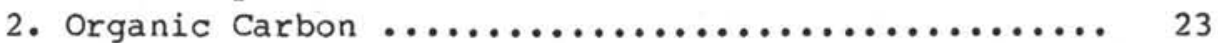

3. Pyrolysis by Rock-Eval ................... 27

4. Routine High-Molecular-Weight Hydrocarbon

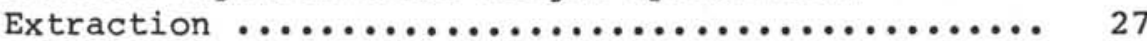

IV. Data Interpretation -- A Brief Guide ............... 31

A. Gas Geochemistry ........................... 31

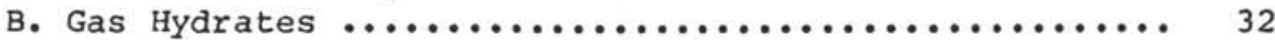

C. Bitumen Geochemistry ...................... 35

D. Organic Carbon Geochemistry ................. 36

E. Pyrolysis ................................. 41

1. Procedure ............................. 41

2. Guide for Interpretation of Rock-Eval Results .... 41

V. Acknowledgments $\ldots \ldots \ldots \ldots \ldots \ldots \ldots \ldots \ldots \ldots \ldots \ldots \ldots \ldots \ldots \ldots \ldots \ldots$

VI. $\quad$ Appendices $\ldots \ldots \ldots \ldots \ldots \ldots \ldots \ldots \ldots \ldots \ldots \ldots \ldots \ldots \ldots \ldots \ldots \ldots \ldots \ldots \ldots . \ldots \ldots$

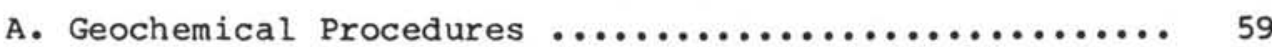

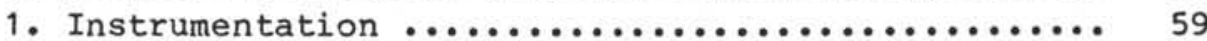

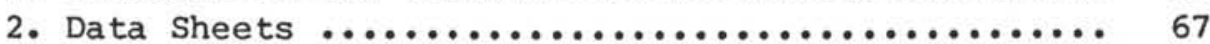

B. Bibliography ......................... 77

1. Index to Organic Geochemistry Information Published in the DSDP Initial Reports, organized by compound type. ....................... 
TABLE OF CONTENTS--Continued

Page

2. Index of DSDP legs and sites with Organic Geochemical Information. ..................... 84

3. Index of Organic Carbon Determinations in DSDP Initial Reports, organized by leg number. ....... 93

4. References Published on Organic Geochemistry in

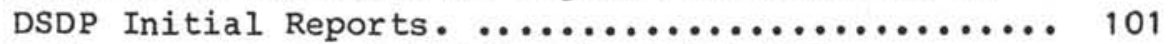

5. References to be Published in Initial Reports DSDP Vols. 88 - 96. ............................ 127

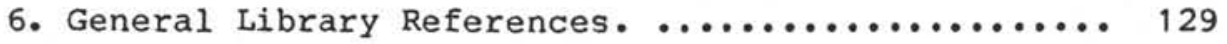

C. Methane and other Hydrocarbons in Marine Sediment

(Reprint from Ann. Rev. Earth Sci., 1983, 11:299-327)

D. Hydrates of Natural Gas: A Review of their Geologic

Occurrence (Reprint from Geological Survey Circular 825) 
1. Floor plan of the Forecastle deck and location of instruments

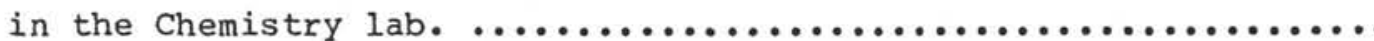

2. Generalized flow charts of analyses for hydrocarbon monitoring and of actions taken in case of hydrocarbon shows. ................ 9

3. Sampling scheme for frozen organic geochemistry samples, gas analysis (headspace) and interstitial waters. Left column: old scheme (prior to April 1986). Center column: scheme proposed by Gieskes and Peretsman (1986) for interstitial waters. Right column: revised scheme incorporating geochemistry, gas analysis, and interstitial waters. ................................. 1

4. Generalized sample flow chart for Physical Properties and

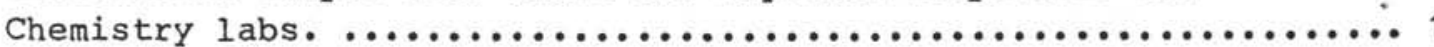

5. Variations of methane/ethane ratios in vacutainer samples from DSDP sites (Ocean Drilling Program Guidelines for Pollution Prevention and Safety. JOIDES Journal Vol.xII, Special Issue No. 5) 21

6. Comparison of results from vacutainer sampling of gas pockets (left) and headspace sampling ( $r$ ight) after heating $10-\mathrm{cm}^{3}$ of sediment in an oil bath $\left(70^{\circ} \mathrm{C}\right.$ for $\left.45 \mathrm{~min}\right)$. Samples of

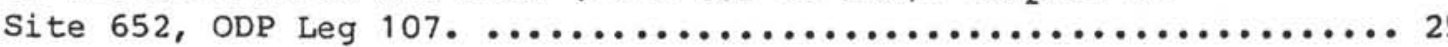

7. Simplified chart to compare various indicators of thermal maturity in sediments. ................................ 33

8. General scheme of hydrocarbon formation as a function of burial of source rocks. Actual depths vary according to particular geological situation and heat flow. (From: B.P. Tissot \& D.H. Welte, 1984: Petroleum Formation and Occurrence. Springer, Berlin,

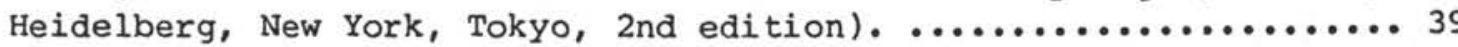

9. Schematic diagram of Rock-Eval pyrolysis device. From: Tissot \& Welte (1984). Petroleum Formation and Occurrence. Springer,

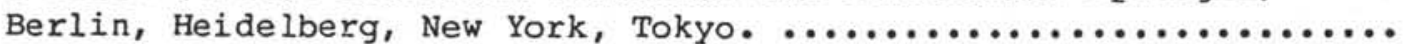

10. Example of a Rock-Eval trace. From: Tissot \& Welte (1984). Petroleum Formation and Occurrence. Springer, Berlin,

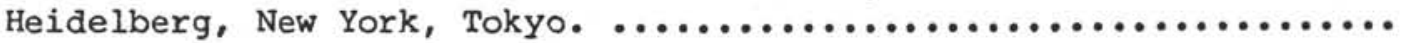

11. HI/OI plot from Rock-Eval pyrolysis data. This is an adapted version of the so-called Van Krevelen diagram, relating chemical characteristics of organic matter in sediments to origin of organic matter, maturity, and type of hydrocarbons produced. ...... 


\section{LIST OF FIGURES--Continued}

Figure

Page

12. Productivity Index (PI) derived from Rock-Eval pyrolysis. PI increases smoothly with depth when no migrated hydrocarbons are encountered in the sediments (a). Rapidly increasing PI indicates the presence of migrated hydrocarbons (b).. 55

13. Example of CPLOT output of a standard gas sample analyzed with the

Natural Gas Analyzer. ................................ 61

14. Example of CPLOT output of a standard mixture of $n$-alkanes analyzed by capillary gas chromatography. 


\section{LIST OF TABLES}

Table

Page

1. Time estimates for routine analyses in minutes. ............ 13

2. Experimental conditions for gas chromatography ............. 29

3. A sample printout of Rock-Eval parameters which are described

in the text. ..................................... 51 


\section{INTRODUCTION}

This manual was produced by the Ocean Drilling Program (ODP) to serve as a guide for the organic geochemist, and the chemistry technicians aboard JOIDES Resolution (SEDCO/BP 471). It treats aspects of the following shipboard chemistry program:

(1) sample collection and analysis for immediate safety decisions to avoid oil and gas accumulations in sediments drilled;

(2) the collection and preservation of samples for subsequent shorebased organic geochemical research; and

(3) the acquisition of organic geochemical data with the shipboard instrumentation.

This manual includes details on sampling procedures, data interpretation, and information on previous DSDP/ODP work. Routine sampling intervals, analytical procedures, and sample flow should follow these guidelines to ensure consistency from leg to leg.

\section{A. DUTIES OF SHIPBOARD ORGANIC GEOCHEMIST}

The success of the ODP organic geochemistry program depends to a large extent upon the interest and actions taken by the on-board representatives of the organic geochemical community. These scientists have five major duties:

1. to assist the Co-Chief Scientists and ODP Operations Superintendent in making proper decisions to avoid significant gas and/or oil accumulations during the drilling operations;

2. to ensure that the designated routine program for analyses of gases and organic carbon is maintained;

3. to assure collection of core samples that are frozen aboard ship, curated by ODP, and distributed to the scientific community on request;

4. to collect samples for their own research program and for the research programs of others, after such programs have been approved by the Co-Chief Scientists and ODP;

5. to provide organic geochemical reports for inclusion in the Hole Summaries and in the Proceedings of the Ocean Drilling Program volumes.

If there are questions concerning duties, procedures, or problems, contact:

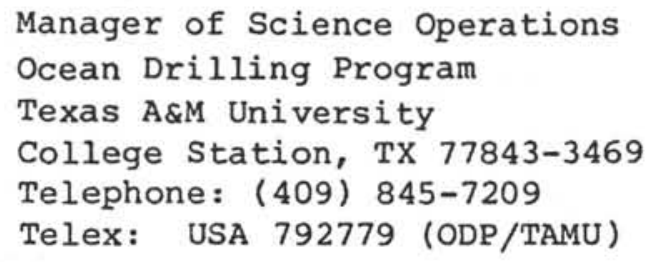




\section{B. SAFETY}

The primary responsibility of the shipboard organic geochemist is to provide, on the basis of his observations and expertise, advice concerning the probable risks of an uncontrolled release of petroleum hydrocarbons, that is, gas and/or oil. Impending risks to the ship and/or to the environment must be assessed, and the Co-Chief Scientists and ODP Operations Superintendent advised in time that drilling can be terminated and the hole plugged before penetration of a hazardous depth interval. The decision as to whether drilling is to be terminated and the hole abandoned rests with the Co-Chief Scientists and the ODP Operations Superintendent.

organic geochemical procedures which can be performed quickly and reliably on shipboard are, at best, able to indicate possible risk. Such procedures should be interpreted in conjunction with geological, paleontological, and geophysical data. Although this function is the responsibility of the Co-Chief Scientists and the ODP Operations Superintendent, the shipboard organic geochemist assists with this multidisciplinary interpretation.

Generally, the hydrocarbon monitoring program consists of three main elements: (1) visual inspection, (2) gas analysis, and (3) pyrolysis. Other factors such as shale density and drilling breaks can be taken into account in the overall assessment of the potential danger in encountering significant quantities of hydrocarbons.

\section{RESOURCES AVAILABLE TO THE ORGANIC ANALYST}

We compiled this manual as a reference guide for shipboard organic geochemists, recognizing that the tasks on board may not fall into the respective expertise of specialized scientists. It is based upon the experiences of individuals who have participated in both DSDP and ODP operations.

Some of the resources aboard JOIDES Resolution include:

1. the diverse backgrounds and scientific knowledge of the shipboard scientific party, including previous DSDP and ODP experience,

2. shipboard reports from previous DSDP and ODP legs, on file in the scientists' lounge,

3. a complete collection of DSDP Initial Reports, ODP Hole Summaries and/or Proceedings of the Ocean Drilling Program volumes.

4. sophisticated shipboard equipment for geochemical studies with detailed operating/maintenance manuals,

5. the practical experience and instrumental expertise of the shipboard technicians. The technicians are very helpful in situations new to the shipboard scientist, and usually have had several legs worth of experience dealing with analytical and scientific problems. 


\section{INSTRUMENTATION EOR ORGANIC GEOCHEMISTRY}

Modern instrumentation for organic geochemistry is available in the chemistry laboratory of JOIDES Resolution. These instruments include the following (Figure 1):

1) Hewlett-Packard 5890A Gas Chromatograph with Option 820 (Natural Gas Analyzer (NGA)], two detectors [flame ionization (FID) and thermal conductivity. (TCD)], and HP 19395A Headspace Sampler (HSS). For analyses of : gases in sediments.

2) Hewlett-Packard 5890A Gas Chromatograph with both FID and TCD which can accept either packed or capillary columns. For determination of low- and high-molecular-weight hydrocarbons in extracts.

3) Hewlett-Packard 3350 Laboratory Automation System (LAS). Receives data from the gas chromatographs through $A / D$ converters and stores ra'w and processed data. For calibration and automated instrument runs.

4) Rock-Eval II with TOC (Total Organic Carbon) Module. For determination of source, amount, and maturity of organic matter and used primarily for petroleum monitoring.

5) Coulometrics Carbon Apparatus. For the accurate determination of inorganic and organic carbon. The Total Carbon Apparatus is used for determinations of organic carbon by difference, and a liquid sample nodule is available for the determination of dissolved organic carbon and total carbon in interstitial waters.

b) Carle Series 100 Analytical Gas Chromatograph. For rapid jeterminations of $C_{1}, C_{2}$, and $C_{3+}$ in gas.

7) Perkin Elmer $240 \mathrm{C}$ Elemental Analyzer. For determinations of carbon, nitrogen, and sulfur in sediments.

3) Halliburtion UV Fluorescence Box. For the detection of heavy hydrocarbon accumulations in the unsplit or split core. This instrument is located in the entry of the core laboratory. 


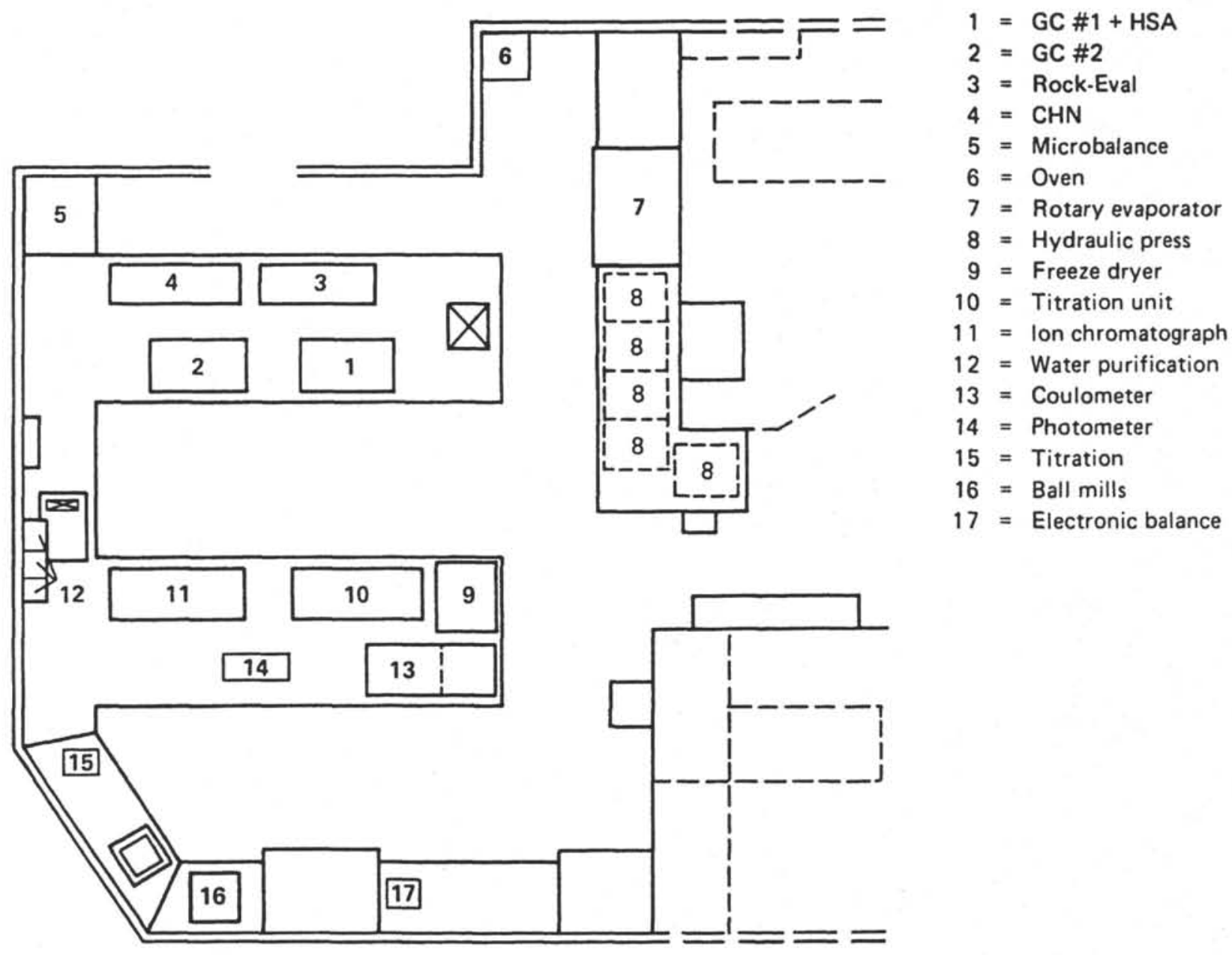

Figure 1. Floor plan of the Forecastle deck and location of instruments in the Chemistry lab. 


\section{GAS AND OIL MONITORING PROCEDURES}

As hydrocarbon generation is a natural and inevitable result of the maturation of buried organic matter, the objective from the safety standpoint is to distinguish potentially hazardous accumulations of hydrocarbons against the background of the normal increase in hydrocarbon content with depth. For this purpose it is necessary to: (1) estimate the current capacity of the organic matter to generate hydrocarbons, and (2) compare this estimate with the actual presence of hydrocarbons, taking into account factors that could promote migration and accumulation of hydrocarbons.

The degree of organic-matter maturation and its capacity to generate hydrocarbons may be estimated by an evaluation of the following properties of gas and sediments:

1) the content of $\mathrm{C}_{2}-\mathrm{C}_{5}$ hydrocarbons relative to methane: the $\mathrm{C}_{1} / \mathrm{C}_{2}$, ratio changes from more than 1,000 for immature to less than $\$ 00$ for mature organic matter;

2) Rock-Eval parameters: Rock-Eval pyrolysis yields information on TOC, presence of migrated hydrocarbons, and origin and maturity of organic matter.

Evidence for the migration and accumulation of hydrocarbons may be discerned on the basis of two main features:

1) a sharp increase in the content or a change in the composition of hydrocarbons compared with that observed in overlying strata, and

2) a discrepancy between hydrocarbon content and actual maturity of the organic matter, as well as a lack of correlation between change in hydrocarbon composition and concentrations relative to lithology, stratigraphy, total-organic-carbon content, and other parameters characterizing in situ deposits.

Employing techniques outlined in Chapter III of this manual, and following routine sampling programs in the course of drilling, the geochemist can obtain information on downhole variation of hydrocarbon content and composition and can predict "normal" distribution trends of gaseous and liquid hydrocarbons. Plots of $\log C_{1} / C_{2}$ ratios vs. depth give downhole trends, as do plots of the various Rock-Eval parameters. Deviations from these trends toward a significantly higher contribution of heavier hydrocarbons justify caution.

Figure 2 is a general flow chart of procedures and decisions to be made during real-time hydrocarbon monitoring. The decision to suspend cutting cores to wait for geochemical results may be unpopular, but in cases of "abnormal" hydrocarbon occurrences, slowing down drilling progress is much better than subjecting the ship to safety hazards and possible pollution. Details are given in the "Ocean Drilling Program Guidelines for Pollution Prevention and Safety" (JOIDES Journal Vol. XII, Special Issue No. 5, March 1986). 


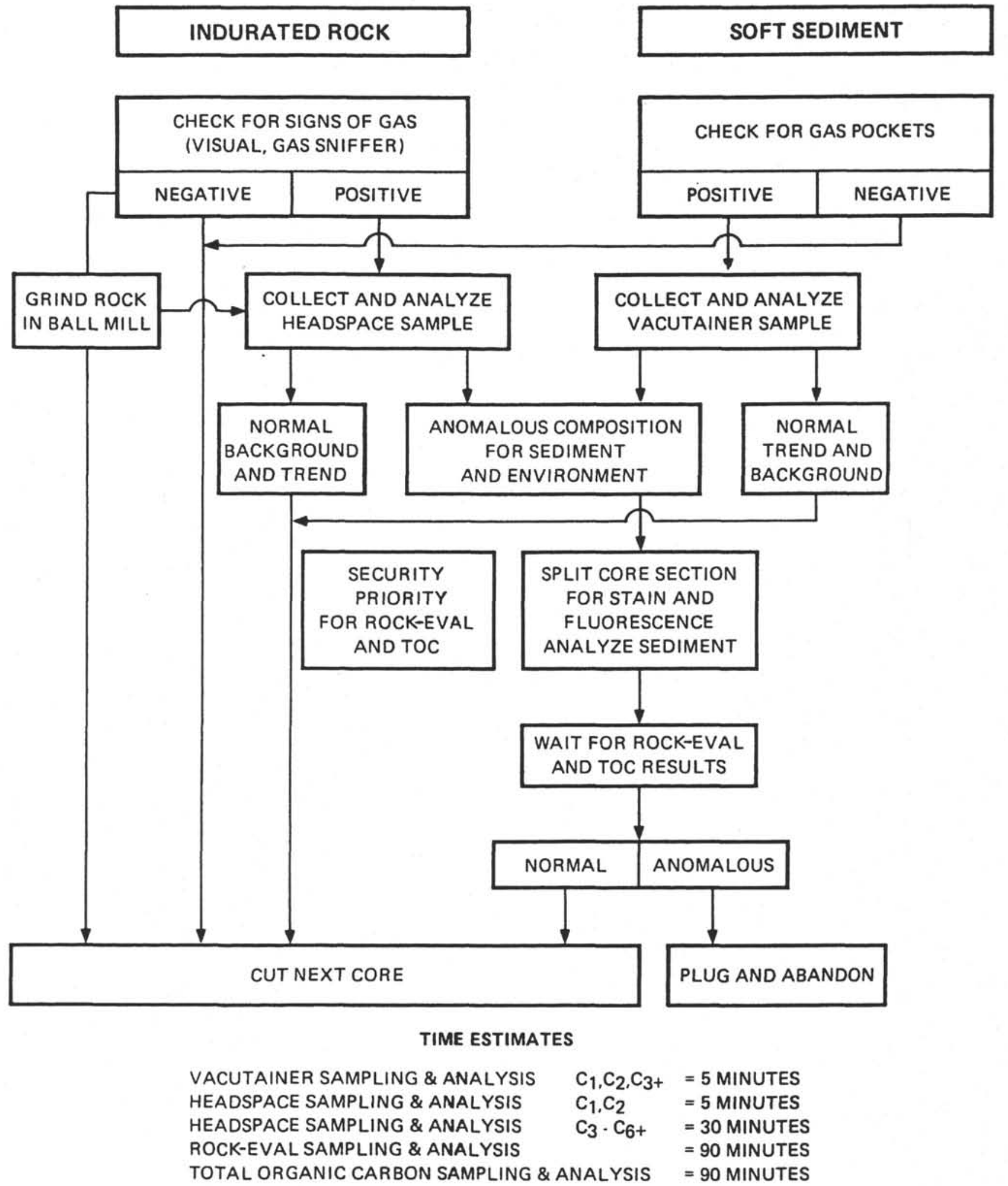

Figure 2. Generalized flow charts of analyses for hydrocarbon monitoring and of actions taken in case of hydrocarbon shows. 


\section{SAMPLING AND ANALYSIS}

\section{A. ROUTINE SAMPLING PROGRAM FOR SHIPBOARD ANALYSES}

Sampling for the shorebased organic geochemistry studies is another important function of the shipboard organic geochemist, in addition to the main responsibility of hydrocarbon monitoring. This task provides samples for detailed organic geochemical analyses that cannot be carried out on board.

Sampling must be in compliance with the ODP Sample Distribution Policy. As is the case with any sampling routine, the collection of material for shipboard use and for shorebased research/curating must be coordinated with other participating scientists. Sample requests for all non-routine shipboard and all shorebased organic geochemistry programs are submitted to ODP on the "ODP Sample Request Form" by the individual investigators at least two months prior to the start of the cruise. These requests are approved for shipboard sampling, deferred for shorebased sampling, or rejected by the leg's Co-Chief Scientists and ODP Curator.

The shipboard organic geochemist contributes to the scientific information derived from the leg by devising a program using the shipboard facilities to obtain samples and data. The research is to be completed at shorebased laboratories following the cruise, in time for contribution to the Proceedings of the Ocean Drilling Program for that leg. The research plan is discussed with the Co-Chief Scientists prior to the leg in order to seek their agreement with the shipboard part of the program. The combination of individual research programs with the routine program on board--including results from the hydrocarbon-monitoring program--should yield optimum results in terms of sample frequency and data consistency.

1. Geochemical Parameters from Routine Sampling

Ideally, geochemical parameters measured routinely aboard ship should include the following:

- Total carbon, carbonate carbon (organic carbon by difference, except for high carbonate samples), measured with the Coulometrics $\mathrm{CO}_{2}$ Coulometer;

- Amount of volatile hydrocarbons, amount of hydrocarbons released from thermal cracking of kerogen, temperature of maximum release of hydrocarbon from kerogen, and total organic carbon (TOC) by Rock-Eval pyrolysis;

- Composition of gas in gas pockets and in sediment by vacutainer and headspace sampling $\left(\mathrm{C}_{1}-\mathrm{C}_{6+}\right.$, air).

In addition, shipboard facilities allow the following optional measurements:

- Dissolved organic and inorganic carbon in pore waters measured with the Total Carbon Apparatus attached to the Coulometer;

- Amount and character of extractable high-molecular-weight hydrocarbons by gas chromatography.

Inorganic geochemical measurements include;
- Concentrations of $\mathrm{Ca}^{2+}, \mathrm{Mg}^{2+}, \mathrm{So}_{4}{ }^{+}, \mathrm{K}^{+}$in pore waters by ion chromatography. 
- Concentration of nitrate, ammonia, silica, and $\mathrm{Fe}^{2+}$ in pore waters by photometry.

- Chloride concentration, salinity, alkalinity and $\mathrm{pH}$ of pore waters.

To maximize the value of these analyses, they should be made on a single sample or series of adjacent samples. Time estimates for these analyses, including calibration and, in some cases, preparation, are listed in Table 1 .

\section{Sampling Scheme}

Because many diagenetic changes occur in the topmost $100-150 \mathrm{~m}$ of the sediment column, sampling of this interval of intense geochemical processes should be concentrated in the uppermost cores of a hole. Combining these sampling efforts and analyzing adjacent samples of gas, interstitial water, and particulate organic matter will provide an extraordinary data base for geochemical investigation and further geochemical research on shore.

Maximum information with minimum disruption of sedimentary sequences can be achieved with the following routine sampling procedure (Figure 3 ):

- $6 \mathrm{~cm}$ of whole-round sediment taken from Section 3 or 4 of Core 1 for interstitial water $(5 \mathrm{~cm})$ and shipboard headspace gas analyses $(1 \mathrm{~cm})$;

- 10-15 cm of working-half sediment taken from Core 2 for sampling of interstitial water and gas;

- $30 \mathrm{~cm}$ of whole-round sediment taken from Core 3 for shorebased organic geochemistry $(25 \mathrm{~cm})$, interstitial water $(\overline{5 \mathrm{~cm}})$ and gas analyses;

- 10-15 cm of working-half sediment taken from Cores 4 and 5 for interstitial water and gas analyses;

- $30 \mathrm{~cm}$ of whole-round taken from Cores $6,9,12,15,18$, etc. to total depth for shorebased organic geochemistry, interstitial water, and gas analyses.

Note: Interstitial water subsamples are stored for shorebased research; gas subsamples can be stored in vacutainers for shorebased research.

An outline of sample flow through the laboratory is depicted in Figure 4. XRD analyses and analyses other than carbonate determination on Physical Properties samples are limited by time available and priorities stated by scientists and Co-Chief Scientists. In detail, sampling and methods for individual analyses are discussed in the following paragraphs.

\section{B. FROZEN ORGANIC GEOCHEMISTRY SAMPLES}

Organic matter contained in marine sediment and rock cores is readily altered microbially and chemically through oxidation and by exposure to light. Furthermore, a vital portion of the organic matter is highly volatile and readily lost from the cores. Such alterations prior to study can result in faulty data and erroneous conclusions. Immediate shipboard study is therefore desirable, if time, manpower, and equipment permit.

When complete shipboard analyses are impossible, the best practical solution is to (1) cap, label, and promptly freeze portions of core and (2) seal selected smaller samples in labeled metal cans which are frozen 
Table 1: Time estimates for routine analyses in minutes.

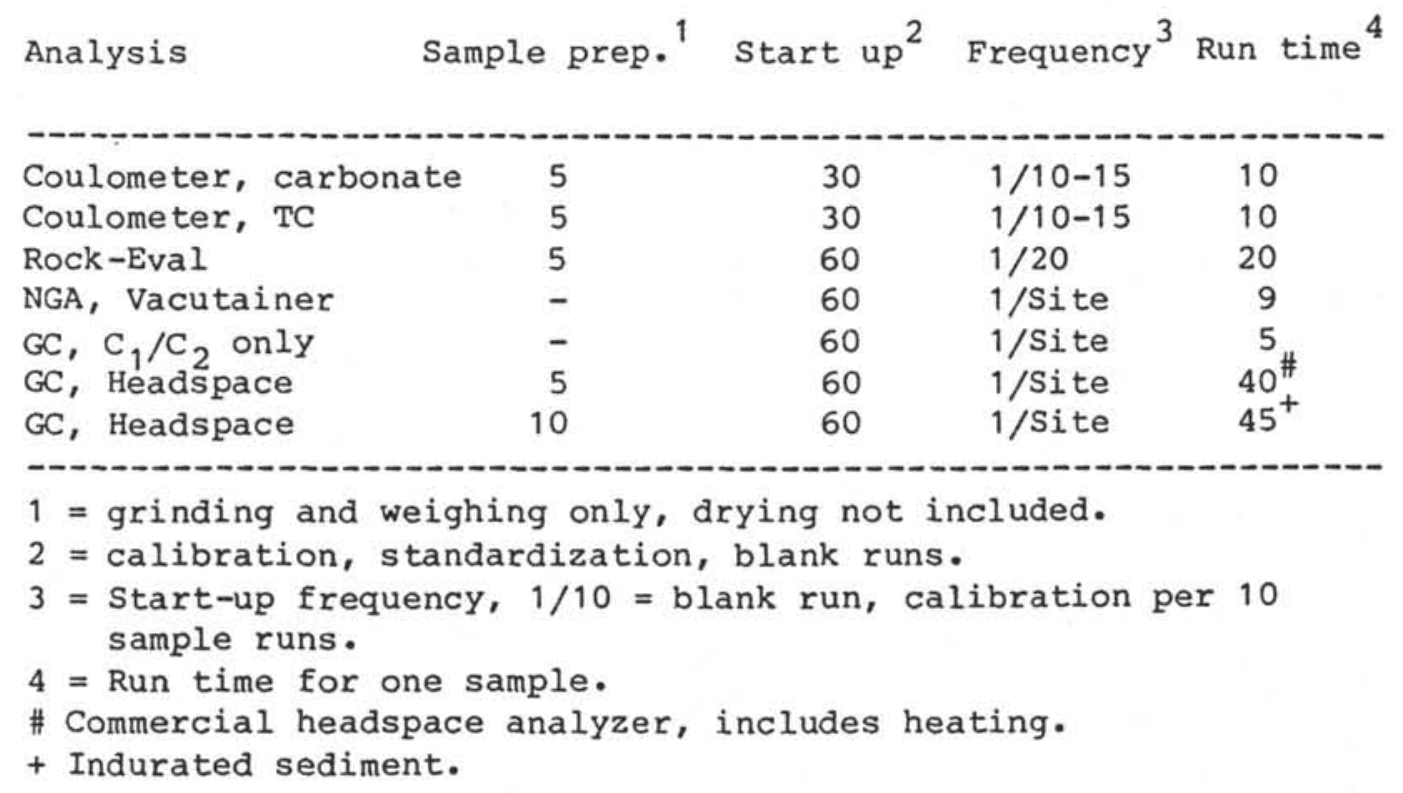




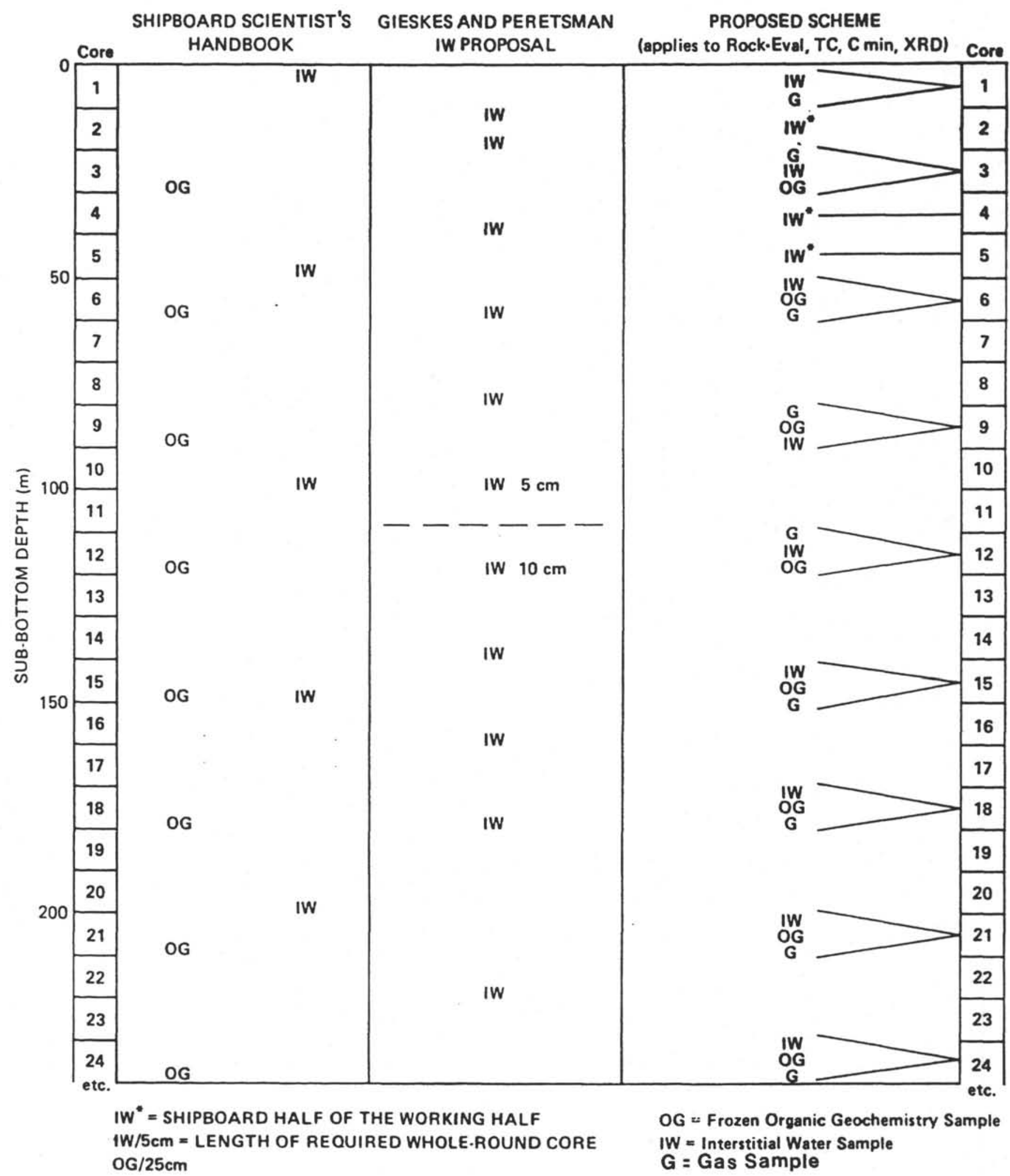

Figure 3. Sampling scheme for frozen organic geochemistry samples, gas analysis (headspace) and interstitial waters. Left column: old scheme (prior to Apri] 1986). Center column: scheme proposed by Gieskes and Peretsman (1986) for interstitial waters. Right column: revised scheme incorporating geochemistry, gas analysis, and interstitial waters. 


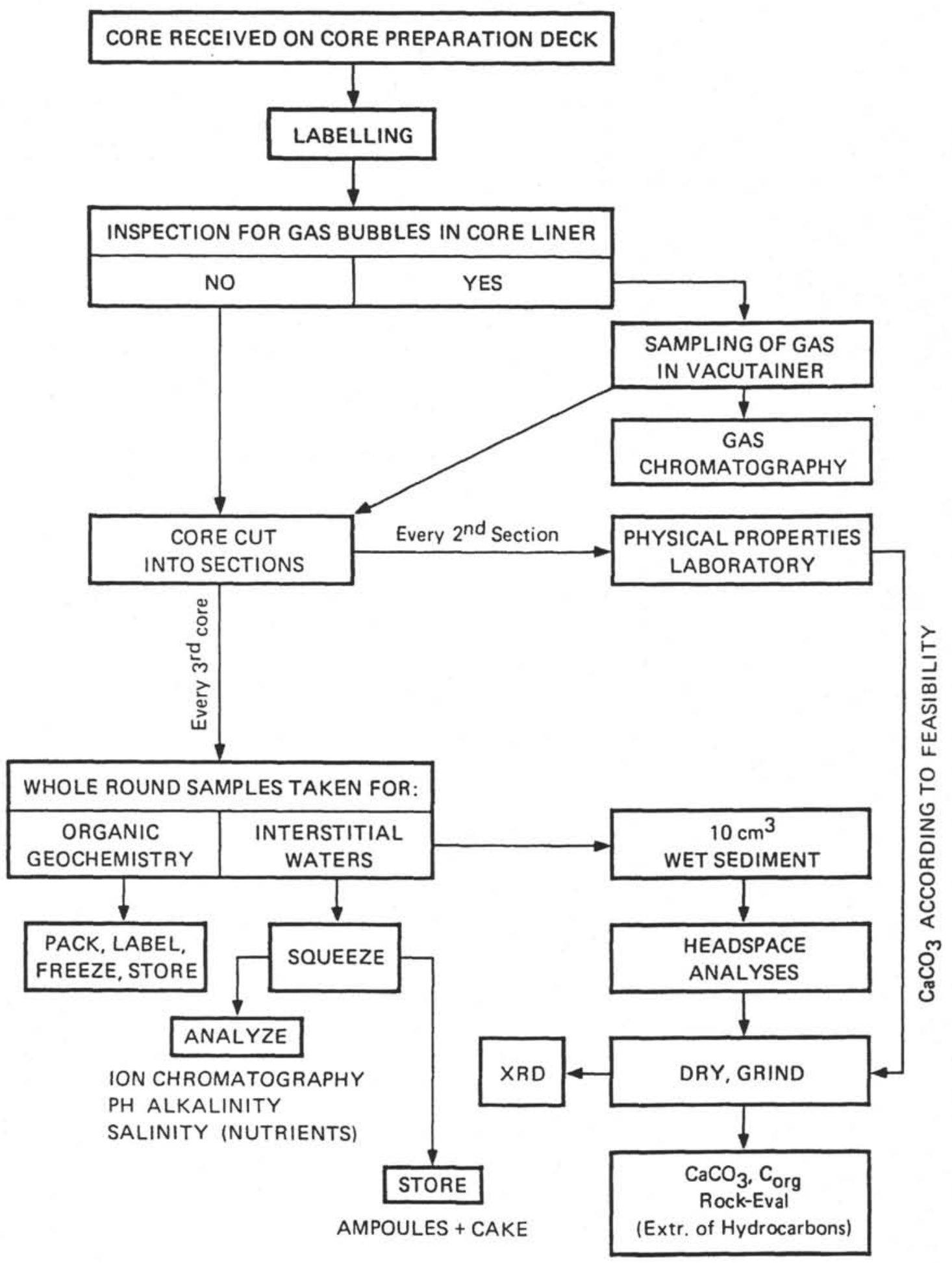

Figure 4. Generalized sample flow chart for Physical Properties and Chemistry labs. 
immediately. All such samples must be maintained frozen on board, and off-loaded only after arrangements have been made for shipment of the samples in the frozen state to the ODP frozen-sample repository or directly to the requesting investigator. ODP curatorial and logistics representatives are responsible for assuring that samples are maintained in a frozen state on board ship and during transit to their destination.

Organic geochemistry (OG) samples are usually taken at each site by the chemistry technicians, assisted by the organic geochemist. This operation involves the following: $25-\mathrm{cm}$ sections of sediment core may be removed every 30 meters, minimizing chances of contamination during handling. Sampling in material of high interest to the organic geochemistry community (e.g., black shales) may be increased to one section every two cores, if good recovery is achieved and at the discretion and approval of the Co-Chief Scientists and the ODP Curatorial Representative. The samples are immediately frozen aboard ship. Because these samples are frozen, they constitute a unique collection which will be available to future investigators. One quarter of every such core sample, split longitudinally, remains in permanent frozen archive. Although taking whole-round core samples interrupts stratigraphic control of the sedimentary sequence, vital information on the nature and age of significant boundary horizons is not permanently lost. It is necessary in any case to cooperate with sedimentologists and paleontologists during sampling, and sampling should be reasonably flexible.

\section{ROUTINE ANALYSES FOR ORGANIC GEOCHEMISTRY}

1. Gas Analysis

$\overline{B e s}$ des being crucial for real-time safety monitoring of hydrocarbons, results of the routine gas-analysis procedure are of considerable scientific value. Gaseous hydrocarbons and $\mathrm{CO}_{2}$ are, in addition to kerogen and DOC, the end-members of thermal and microbial diagenesis and catagenesis of organic matter. Interrelation of dissolved species (nutrients, alkalinity, DOC), the solid phases, and gas is complex. It is desirable to monitor all three phases downhole and, in order to maximize results, perform parallel analyses on the same sample for each of these parameters. The data base thus created is essential for further studies on the transformation of organic matter during burial.

The main objective of the shipboard gas program, however, is to assess potential safety or pollution hazards when encountering hydrocarbon accumulations during drilling.

Three methods are employed currently aboard JOIDES Resolution to sample gas and to monitor concentrations and ratios of hydrocarbon gases:

- vacutainer sampling of gas pockets in soft sediments;

- headspace techniques for gas analysis in connection with the Natural Gas Analyzer;

- rapid headspace sampling of gas in a modified ball mill for indurated sediments.

While the first and last methods are primarily intended to serve as guidelines for quick decisions concerning ship safety and pollution control, the second method produces data trends to be used (in connection 
with vacutainer results) for safety purposes.

$$
\text { a. Vacutainer Sampling }
$$

Sampling for the presence of hydrocarbon gases must be performed at all sites where there is a chance of encountering significant levels of hydrocarbons. As the core barrel is brought on deck and the core liner removed, a chemist or marine technician checks for gas pockets, bubbles, or frothing within the liner. Any evidence for abnormal hydrocarbon quantity is immediately reported to the ODP Operations Superintendent. The need to monitor for such hydrocarbons is necessary for all sediments. Generally the geochemist and technicians share the sampling and analytical work.

The organic geochemist is notified if hydrocarbons are suspected, so that samples can be analyzed immediately. Ideally, samples for gas chromatographic analysis are taken prior to cutting and capping to prevent contamination from glues and other materials used in these processes. However, the presence of gas is also marked by a bulging of the end caps of sealed core liners. As the sediments degas with the change in pressure and temperature, sections of core material are pushed apart by gas expansion. The geochemist or the chemistry technician uses a liner penetrator with syringe attachment and evacuated glass container (vacutainer) to sample these gas pockets. The sample is taken to the chemistry lab and analyzed by gas chromatography. Currently, a $5-\mathrm{mL}$ sample of gas is injected into a $0.25-\mathrm{mL}$ sample loop of the Hach gas chromatograph. Concentrations of components in the gas mixture are calculated from comparison with standards based on integrator results. Volume ratios of $C_{1} / C_{2+}$ are plotted on log scales to observe trends in gas composition with depth. Typical trends are shown in Figure 5, a compilation of vacutainer gas composition encountered in DSDP legs.

\section{b. Headspace analysis from unconsolidated sediments}

At the time of writing this manuscript (after ODP Leg 107), the following headspace procedure was used:

Hydrocarbon gases, $\mathrm{C}_{1}$ through $\mathrm{C}_{5}$, were monitored on the Hewlett-Packard (HP) $5890 \mathrm{~A}$ Gas Chromatograph plus NGA using a flame ionization detector and the HP Headspace Sampler (HSS). Methane levels were low, allowing good separation between methane and the other higher molecular-weight gases on a DC200 packed column. Run time for the analysis was 9 minutes. Methane, ethane, propane, i-butane, n-butane, i-pentane, and n-pentane are separated in order of increasing retention time and by molecular sieves. Peak areas were measured and calibrated on the HP 3392A Integrator and the HP 3350 Laboratory Automation System.

A $10-\mathrm{cm}^{3}$ sediment sample was collected upon initial sectioning of the core for headspace analysis. The sediment sample was placed in a $20 \mathrm{cc}$ glass vial and sealed immediately with a septum and crimped metal cap. The vial was then heated in a hot oil bath at $70^{\circ} \mathrm{C}$ for 30 minutes. The oil bath is part of the HSS. After equilibration, the HSS performs a preprogrammed sequence using an automated valve and loop sampling system. A sampling needle pierces the septum and helium pressurizes the headspace 


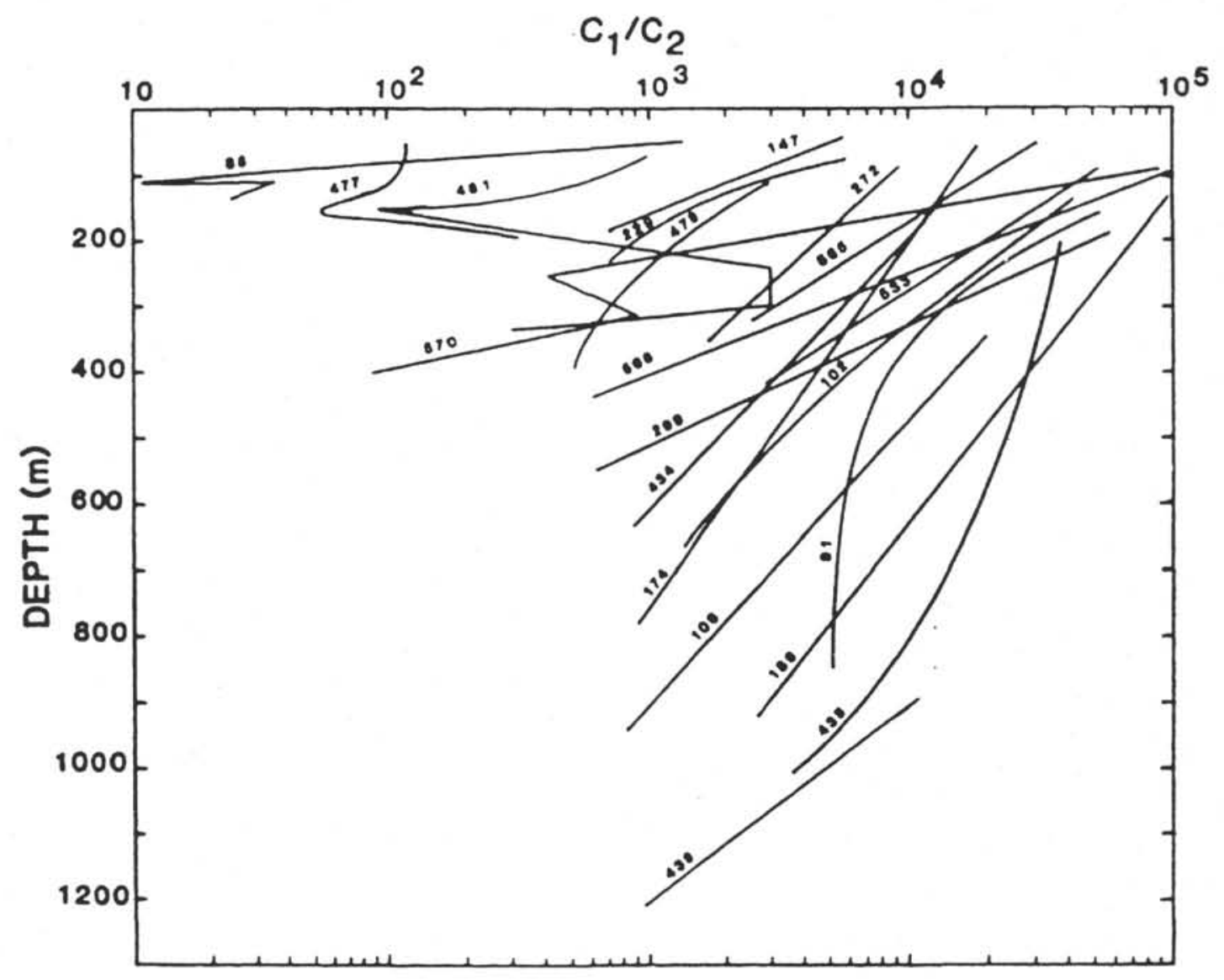

Figure 5. Variations of methane/ethane ratios in vacutainer samples from DSDP sites (Ocean Drilling Program Guidelines for Pollution Prevention and Safety. JOIDES Journal Vol. XII, Special Issue No. 5). 
vial. The headspace gas passes through a $0.25-\mathrm{mL}$ sample loop. The loop is then flushed into the helium carrier gas flow and the sample is delivered through a heated transfer line directly into the GC's injection port.

Concentrations of hydrocarbon gases were computed from standard sample detector responses and preprogrammed methods in the LAS system. Volume ratios of $C_{1} / C_{2}$ or $C_{1} / C_{2+}$ are plotted on log scale to observe trends in gas composition downhole. Figure 6 compares vacutainer results with those obtained by the headspace technique on Leg 107.

\section{c. Headspace sampling of gas from indurated sediments}

Because gas evolving in indurated sediments does not form bubbles, but rather bleeds off or hisses, a rapid headspace technique designed for indurated sediments is used in conjunction with drilling operations. An approximately $5-\mathrm{cm}^{3}$ piece of indurated sediment is ground in a modified ball mill equipped with a septum. Five $\mathrm{mL}$ of gas extracted through the septum are injected into the GC sample port. Results are recorded in the same way as for the vacutainer technique.

Because of possible future changes in equipment and in sampling policy, sample spacing and preparation/analysis techniques are subject to change. We urge the organic geochemists to perform parallel analyses with vacutainers and headspace techniques wherever possible. This serves two purposes: the results of the two methods can be compared, and a data base is created for the relatively new headspace technique. Because of the small quantity of sample needed for the HSS and the NGA, we suggest that samples for HSS be taken at a rate of 1 per 3 cores, adjacent to the OG sample. After gas analysis, the headspace sample can be used for other analyses (organic-carbon determinations, Rock-Eval pyrolysis, etc.).

\section{Organic Carbon}

The amount of organic carbon ( $\mathrm{C}_{\text {org }}$ ) in a sample is determined in two independent ways in the chemistry lab: (1) by difference from total carbon (TC) and carbonate carbon $\left(\mathrm{C}_{\min }\right)$ as measured with the Coulometer, and (2) by total-organic-carbon (TOC) determinations from Rock-Eval pyrolysis. At moderate-to-high $C_{\text {org }}$ values ( $\left.>0.5 \mathrm{wt} \%\right)$, and in low-to-moderate $(<50 \%)$ carbonate samples, values from the two methods should agree reasonably well. At low C values, TOC readings of the Rock-Eval appear to be erratic. For samples with high $\mathrm{CaCO}_{3}$ contents, the method used to compute C org by difference sometimes yields negative values. Where carbonate carbon $\left(\mathcal{C}^{\mathrm{rg}}\right)$ is very large, the sample should be acidified, washed, and $\mathrm{C}$ determined directly on the residues. A comparison of methods is currentig under way (Summer 1986), and the best method will be recommended for future use in the shipboard laboratory.

If not requested otherwise, TOC and source/maturity determinations by Rock-Eval follow the routine sample spacings listed in Figure 3 and are integrated in the routine program outlined in Figure 4. This sample spacing is the standard prescribed for every sedimentary hole. Additional measurements of $\mathrm{CaCO}_{3}$ and $\mathrm{TOC}$ can be made by request from the geochemists 

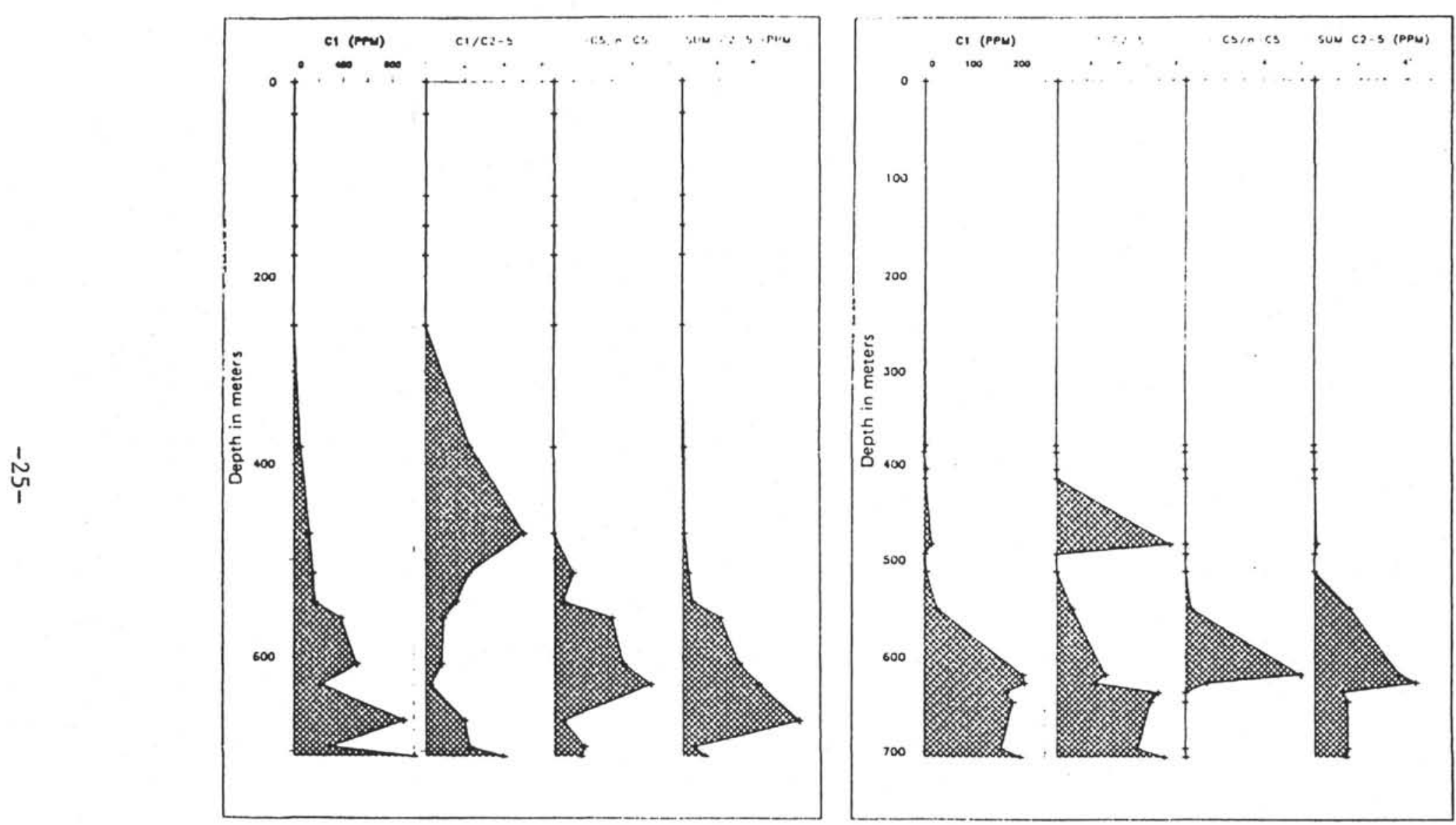

Figure 6. Comparison of results from vacutainȩr sampling of gas pockets (left) and headspace sampling ( $r i g h t$ ) after heating $10 \mathrm{~cm}$ of sediment in an oil bath (70 $\mathrm{C}$ for $45 \mathrm{~min})$. Samples of Site 652, ODP Leg 107. 
and the rest of the scientific party if time permits.

3. Pyrolysis by Rock-Eval

Rock-Eval pyrolysis is closely associated with safety hydrocarbon monitoring because it produces values for two important sediment parameters: the amount of free hydrocarbon in the sediment $\left(S_{1}\right)$ from in situ production and/or migration (oil/gas shows), and the amount of organic carbon present in the sample. Routinely, Rock-Eval pyrolysis is carried out on subsamples of sediment taken for interstitial water and/or gas analyses. Normally a Rock-Eval analysis is made on a sample from every third core downhole. Standard sample size is $100 \mathrm{mg}$ of dried and ground sediment.

This routine sampling and analytical scheme is not used when gasmonitoring results suggest accumulations of migrated hydrocarbons in the sediments. In this case Rock-Eval analyses are done more often as needed for safety monitoring, as outlined in Chapter IV.

The Rock-Eval pyrolysis instrument was developed to serve as an exploration and screening tool for the oil industry, and the accuracy of individual measurements is sometimes debatable. Results of Rock-Eval pyrolysis are usually consistent within themselves, but when used for drawing scientific conclusions, they should be interpreted with caution. Some brief notes on interpretation and pitfalls of the method are given below.

4. Routine High-Molecular-Weight-Hydrocarbon Extraction

Extraction and analysis of high-molecular-weight-hydrocarbon compounds from sediments aboard JOIDES Resolution are scientific procedures which are performed in the chemistry laboratory at the request of, or by, shipboard organic geochemists. Because methodology and the experimental setup for this kind of analysis are not standardized throughout the scientific community, it is reasonable to assume that scientists intending to perform extraction and analysis in the shipboard laboratory will have their own methods. We suggest using the procedure outlined below on board when information on the high-molecular-weight hydrocarbons is needed for safety monitoring. Although the procedure is rather simplistic, results will be comparable within the scientific framework of ODP. Elaborate characterization of extractable organic matter will still be restricted to shorebased research, because manpower, laboratory space, and instrumentation needed will commonly not be available during cruises.

On Leg 107 the following procedure was employed and yielded good results: Selected samples were subjected to solvent extraction in order to tentatively characterize origin and maturity of organic matter. About 20 grams of each sample were freeze dried, ground, weighed, and ultrasonicated for 2 hours with a mixture of methanol/toluene (3:1). After centrifuging and decanting the solution of extractable hydrocarbons, the extract was evaporated to dryness in a rotary evaporator and weighed. In most cases, the small amount of sample and of the resulting extract precluded quantification. The dried extract was redissolved in HPLC-grade n-hexane, 
and saturated hydrocarbons were separated from aromatic and NSO components by liquid chromatography on commercial CN and silica gel columns (Baker 10, provided in the laboratory). The hexane eluent from these columns was again evaporated and redissolved in $1 \mathrm{~mL}$ of hexane. Two microliters of this hexane solution were injected into the HP 5890A gas chromatograph equipped with a 25-m high-performance capillary column. Instrument setup and column characteristics are given in Table 2.

Retention times from an n-alkane standard were used to identify saturated compounds. Results were reported through the HP Laboratory Automation System and plotted with the CPLOT routine. Ratios of components were computed after manual background correction and automated integration of peaks. 
Table 2: Experimental conditions for gas chromatography.

\begin{tabular}{|c|c|}
\hline Ins trument & Hewlett Packard 5890A \\
\hline Temperature program & $\begin{array}{l}\text { Injection at } 200^{\circ} \mathrm{C} \text {, detector (FID) } 300^{\circ} \mathrm{C} \text {, } \\
\text { initial temperature }(1 \mathrm{~min}) 40^{\circ} \mathrm{C} \text {, rate } \mathrm{A} \\
50^{\circ} \mathrm{C} / \mathrm{min} \text { to } 80^{\circ} \mathrm{C} \text {, purge on after } 0.8 \mathrm{~min} \text {, } \\
1 \mathrm{~min} \text { at } 80^{\circ} \mathrm{C} \text {, rate } \mathrm{B} 10^{\circ} \mathrm{C} / \mathrm{min} \text { to } 300^{\circ} \mathrm{C} \text {, } \\
300^{\circ} \mathrm{C} \text { for } 5 \mathrm{~min} \text {. }\end{array}$ \\
\hline Column & $\begin{array}{l}25-\mathrm{m} \text { HP Ultraperformance capillary, } \\
\text { cross-linked methyl silicone, internal } \\
\text { diameter } 0.2 \mathrm{~mm} \text {, film thickness } 0.11 \\
\text { micron, splitless injection }\end{array}$ \\
\hline Run time & $30 \mathrm{~min}$ \\
\hline
\end{tabular}


IV. DATA INTERPRETATION: A BRIEF GUIDE

The responsibility for integrated interpretation of the multidisciplinary data from hydrocarbon monitoring rests with the Co-Chief Scientists in consultation with the ODP Operations Superintendent. They decide whether drilling continues or the hole is plugged and abandoned. Nevertheless, the shipboard organic geochemist should devise his own forecast and make it known to the Co-Chief Scientists and the Operations Superintendent. He should be prepared to explain the scientific rationale by which the conclusions were reached.

The following is a suggested stepwise procedure for developing a continuing forecașt with regard to the potential of encountering an accumulation of petroleum as drilling in a hole proceeds. Minimizing time for sample collection and analysis is essential. Data and conclusions must be developed immediately to be of value for safety considerations.

There are three basic types of potentially hazardous petroleum occurrences:

1) Migrated petroleum: petroleum, consisting of natural gas and/or crude oil, generated in fine-grained rocks derived from argillaceous or lime muds, which subsequently migrated into adjacent coarser grained, more permeable rocks or clastic sediments;

2) Petroleum from anomalous thermal regimes: petroleum generated in rock units which have been exposed to thermal regimes considerably higher than those near the water/sediment interface, and which has migrated to geological reservoirs; and

3) Gas hydrates: natural gas accumulated as gas hydrate at relatively shallow depth, which may be acting as a cap or seal for gas and possibly for crude oil.

\section{A. GAS GEOCHEMISTRY}

Methane is ubiquitous in all organic-rich, fine-grained sediments. Ethane and higher hydrocarbons are usually generated slowly with depth. Increasing proportions of ethane and the higher homologs relative to methane with depth are normal results of increasing thermal maturation of organic matter. For petroleum accumulations of different types, the indicators which might show an approaching hazardous situation can vary widely. Ethane and higher hydrocarbons are generated at shallow depths. Neopentane (2,2-dimethyl-propane) often is present in these hydrocarbon mixtures in larger concentrations than ordinarily occurs in older, more mature mixtures. Accordingly, a progressive decrease in the ratios of methane to ethane, methane to propane, etc., indicates either (1) advancing stages of thermal genesis, and hence an increasing potential for petroleum to accumulate in adjacent porous strata from which it could be suddenly released, or (2) an approach to an accumulation of mature petroleum which has migrated from depth. As a general guideline, values less than those indicated below for composition of gas in gas bubbles (vacutainers) justify caution:

methane/ethane methane/propane methane/n-butane
15,000 . 
The values above must not be used without qualifying considerations. For example, a significant concentration of neopentane (i.e., concentrations of more than about $10 \mathrm{ppm}$ ) suggests that petroleum genesis is in a very early stage, and an accumulation of petroleum in sufficient concentration to cause a hazardous release is unlikely. A thin underlying sedimentary section, that is, a thin interval to basement, would support the conclusion of low risk.

A rapid increase in the concentrations of the individual light hydrocarbons followed by a sharp decrease should be viewed as a possible hazardous situation, particularly if the drill is approaching an underlying interval where increased porosity (e.g., sand) is expected. In this case the rapid rise in hydrocarbon concentrations might suggest penetration of a thick, low-permeability, overpressured source rock. As the boundary of the more porous and permeable underlying unit is approached, decreased hydrocarbon concentrations in the local rock, and flushing of hydrocarbons into the adjacent unit may have occurred, with petroleum finally collecting in structural highs. On penetration of the underlying high-porosity unit by the drill, collected gas accumulations may be readily released.

Large ratios of methane to higher hydrocarbons do not necessarily indicate that drilling ahead is without hazard. For example, gas percolating upward from the leading edge of a gas-hydrate accumulation may be low in ethane plus higher hydrocarbons. The hazard does not lie in the gas-hydrate zone but in the sediments immediately below, where gas and perhaps petroleum may be pooled beneath the gas-hydrate seal.

Methane with little associated higher hydrocarbons is commonly generated from the microbial decomposition of organic material at depth. Potential sources of gas can be evaluated from microscopic kerogen characterization by the shipboard palynologist/paleontologist. If, for example, the rock (1) contains large amounts of terrestrially derived macerals (vitrinite), (2) displays high vitrinite reflectance measured in polished blocks, (3) shows dark color of organic debris (TAI: Thermal Alteration Index; Figure 7), and (4) has high thermal maturity as determined from pyrolysis parameters, we would expect increasing amounts of thermally derived methane. In such a situation, particularly on approaching a seismic reflector, utmost caution is advised and continuous gas monitoring is essential because of the potential hazard. Many parameters needed to determine diagenetic zones of organic matter (OM) maturation (Figure 7) can be analyzed on board ship. Appendix $C$ is a reprint of a summary article on gaseous hydrocarbons in marine sediments.

\section{B. GAS HYDRATES}

The presence of gas hydrate is often indicated by an anomalous seismic reflection event (BSR: Bottom Simulating Reflector) that approximately parallels the bathymetry and occurs at sediment depths predicted from the pressure-temperature stability field for gas hydrates (Appendix D). The Co-Chief Scientists and the ODP Operations Superintendent should be aware of the location of possible gas-hydrate accumulations, and, currently, approval by the JOIDES Pollution Prevention and Safety Panel is required before suspected gas hydrates can be sampled. When gas hydrates are 


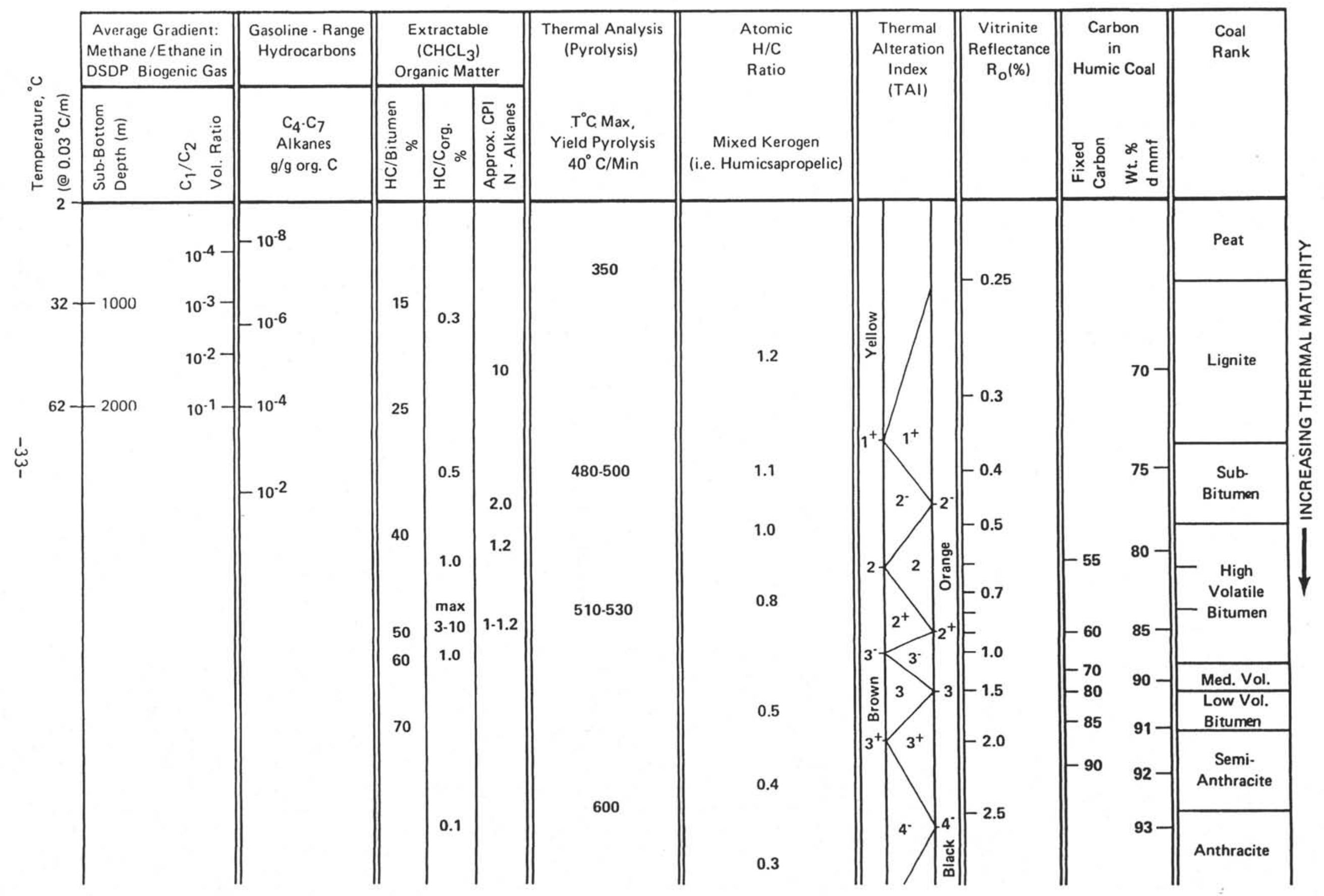

Figure 7. Simplified chart to compare various indicators of thermal maturity in sediments. 
drilled, caution and very close monitoring by the organic geochemist is required. The greatest danger lies in a gas and possible oil accumulation immediately below the gas-hydrate layer. Where gas hydrates have been recognized, previous drilling has always terminated at least 100 meters above the base of the suspected gas hydrate. If solid material is recovered that is thought to contain gas hydrates, verification can be obtained by placing a piece of recovered core material into a carbonate bomb or similar device. Gas hydrates are likely present if the volume of gas evolved exceeds that of sediment by a factor of about 3 or more.

\section{BITUMEN GEOCHEMISTRY}

Examination of cores for hydrocarbon fluorescence under ultraviolet light of ten indicates oil in small amounts, or oil of light color that might not be detected by other means. Oil-stained samples that are old may not fluoresce; thus, failure to fluoresce should not be taken as decisive evidence of absence of hydrocarbons. If hydrocarbons are suspected, cores should be split upon arrival on deck and be inspected under UV excitation in the Halliburton UV box located in the entry to the Core Laboratory. Yellow to brown fluorescence indicates bitumen accumulation. All samples suspected of containing hydrocarbons should be extracted with petroleum ether or methanol/toluene (3:1) and examined by UV fluorometry. Further examination by pyrolysis is essential, and additional investigation by gas chromatography may be warranted.

The following is a method of testing for hydrocarbons employed in commercial drilling. It is fast and can easily be performed on the ship while data are being collected from pyrolysis. To test cores, a few grams of dried sediment are placed in a white porcelain evaporating dish and covered with reagent. It is important that the sediment be dried thoroughly at low temperature, otherwise water within the sample may prevent penetration by the solvent, thus obscuring decisive results. The hydrocarbon extracted by the solvent is called a "cut." The cut is observed under normal light and should be described on the basis of the shade of the coloration, which will range from dark brown to no visible tint.

The most reliable test for hydrocarbons is the "cut fluorescence" test. In this test the effect of the solvent on the sample is observed under ultraviolet light, along with a sample of the pure solvent as control. If hydrocarbons are present, fluorescent "streamers" will be emitted from the sample, and the test is evaluated by the intensity and color of these streamers. Some shows will not give a noticeable streaming effect but will leave a fluorescent ring or residue in the dish after the reagent has evaporated. This effect is termed a "residual cut." Generally, lowgravity oils will not fluoresce but will cut a very dark brown, and their "cut fluorescence" may range from milky white to dark orange. If no fluorescence is exhibited by the core-catcher samples or their solvent extracts, it can be assumed that liquid petroleum is not present. A dull, yellow-brown fluorescence indicates an asphaltic residue and in itself does not indicate a drilling hazard. Yellow, green, and blue fluorescence indicates asphaltic oil, light oil, and naphtha or gas condensate, 
respectively. The hazard to safety increases in that order.

With sophisticated shipboard instrumentation and capabilities to perform gas chromatography on extracts, further qualitative and quantitative analyses of high-molecular-weight hydrocarbons in extracts can be performed rapidly and easily, but sometimes results suffer from contamination of samples from shipboard contaminants. Certain shipboard oils and greases such as pipe dope, cable grease, and core barrel lubricant can get into the core catcher, and even occasionally inside the core liner. A catalogue of geochemical fingerprints for possible contaminants has been prepared as ODP Technical Note \#6. This note contains gas chromatograms of solvent extractable hydrocarbons in potential organic contaminants. If contamination is suspected, a sample or samples of sediment should be obtained from a freshly cut core section. No safety alarm should be issued until contamination has been ruled out. A rapid gas-chromatographic analysis, including sample preparation, can be performed within 30 minutes.

\section{ORGANIC-CARBON GEOCHEMISTRY}

Biological synthesis of reduced (from $\mathrm{CO}_{2}$ ) carbon compounds is the source of organic carbon in sediments underlying the world oceans. Depending on light penetration and nutriept supply, annual primary production of organic carbon $\left(49 \times 10^{9} \mathrm{ta}^{-T}\right)$ varies greatly from shelf areas and areas of upwelling (about $100 \mathrm{~g} \mathrm{C} \mathrm{m}^{-2} \mathrm{a}^{-1}$ and $300 \mathrm{~g} \mathrm{C} \mathrm{m}^{-2} \mathrm{a}^{-1}$, respeftively) to open-ocean waters of low productivity (about $50 \mathrm{~g} \mathrm{C}$ $\left.m^{-2} a^{-1}\right)$.

of this organic carbon produced in the euphotic zone of the water column, only about $0.1 \%$ finally is preserved in sediments. The remaining 99.9\% is oxidized during sinking or during benthic consumption. Even in anoxic sediments of high sedimentation rates underlying oxygen-deficient water bodies (settings ideal for preservation of organic matter) the percentage of primary-produced carbon finally preserved hardly exceeds $5 \%$. Nevertheless, sedimentary rocks (of all ages) make up the largest reservoir of organic carbon on Earth, estimated to contain about $10^{22} \mathrm{~g}$ of reduced carbon. Average values for open-marine sediments are about $0.1 \%$ by weight; potential oil and gas source rocks are defined to contain more than $0.5 \%$ (detrital rocks) and $0.3 \%$ (carbonate and chemical rocks).

Observations on the interrelation of sedimentation rate, primary production, and preservation of organic carbon in sediments permit an estimate of ancient primary productivity for any given sedimentary unit. Accumulation rates of organic carbon can be computed by data obtained aboard ship:

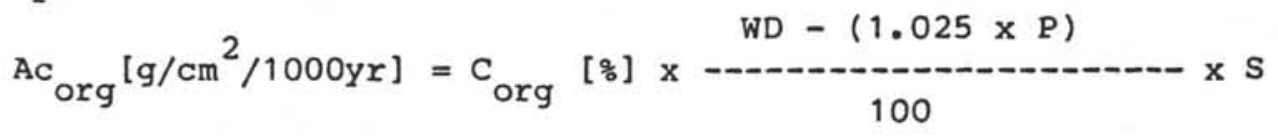

where $\quad$ WD = wet bulk density of sediment;

$1.025=$ density of pore water;

$P=$ porosity;

$S=$ sedimentation rate $[\mathrm{cm} / 1000 \mathrm{yr}]$. 
Paleo productivity can be reconstructed, employing an empiric relationship derived from various sedimentary environments:

$$
R=\frac{C \times D D(1-P)}{(0.003) s^{0.3}}
$$

where

$$
\begin{aligned}
& \mathrm{R}=\text { paleo productivity }\left[\mathrm{g} / \mathrm{m}^{2} / \mathrm{yr}\right] \text {; } \\
& C=C \text { [wt. \%]; } \\
& \mathrm{DP}=\text { dry density }=\text { wet density }-[1.025 \mathrm{x} \mathrm{P}] \text {; } \\
& \mathrm{P}=\text { porosity; } \\
& \mathrm{S}=\text { linear sedimentation rate }[\mathrm{cm} / 1000 \mathrm{yr}] \text {. }
\end{aligned}
$$

Contributions to organic matter are derived from different sources:

- Marine phytoplankton;

- Phytobenthos in shallow water with sufficient light;

- Bacteria;

- Allochthonous, land-derived organic material.

These sources can be identified by various methods, of which Rock-Eval pyrolysis, petrographic investigation of kerogen, and gas chromatography of solvent extracts can be performed aboard ship.

Factors that help preserve organic matter in quantities above the $0.1 \%$ "background" level are:

- Oxygen depletion in bottom waters or in sediment as a result of high organic input;

- Adsorption of certain compounds to mineral particles;

- Preservation of organic compounds as shell constituents;

- Changes in the rate of deposition of sediment organic matter, disrupting the steady state of input and benthic consumption;

- High input of terrigenous organic compounds which are more stable than marine organic matter;

- Dominant input of argillaceous sediments where oxygenation of pore water is restricted.

The background organic carbon in open marine sediments is partially composed of recycled, highly oxidized material of continental origin (the petrographic term is inertinite) and amorphous, uncharacterized remains (probably of bacterial origin).

Organic matter undergoes changes in composition similar to changes in mineral assemblages with increasing burial depth. The three consecutive steps in organic matter transformation are termed diagenesis, catagenesis, and metagenesis. Boundary conditions for this sequence are given mainly by temperature and burial time; pressure contributes only insignificantly. Arbitrary boundaries can be determined by vitrinite reflectance. The general scheme of evolution of the organic fraction and the hydrocarbons produced are depicted in Figure 8. 


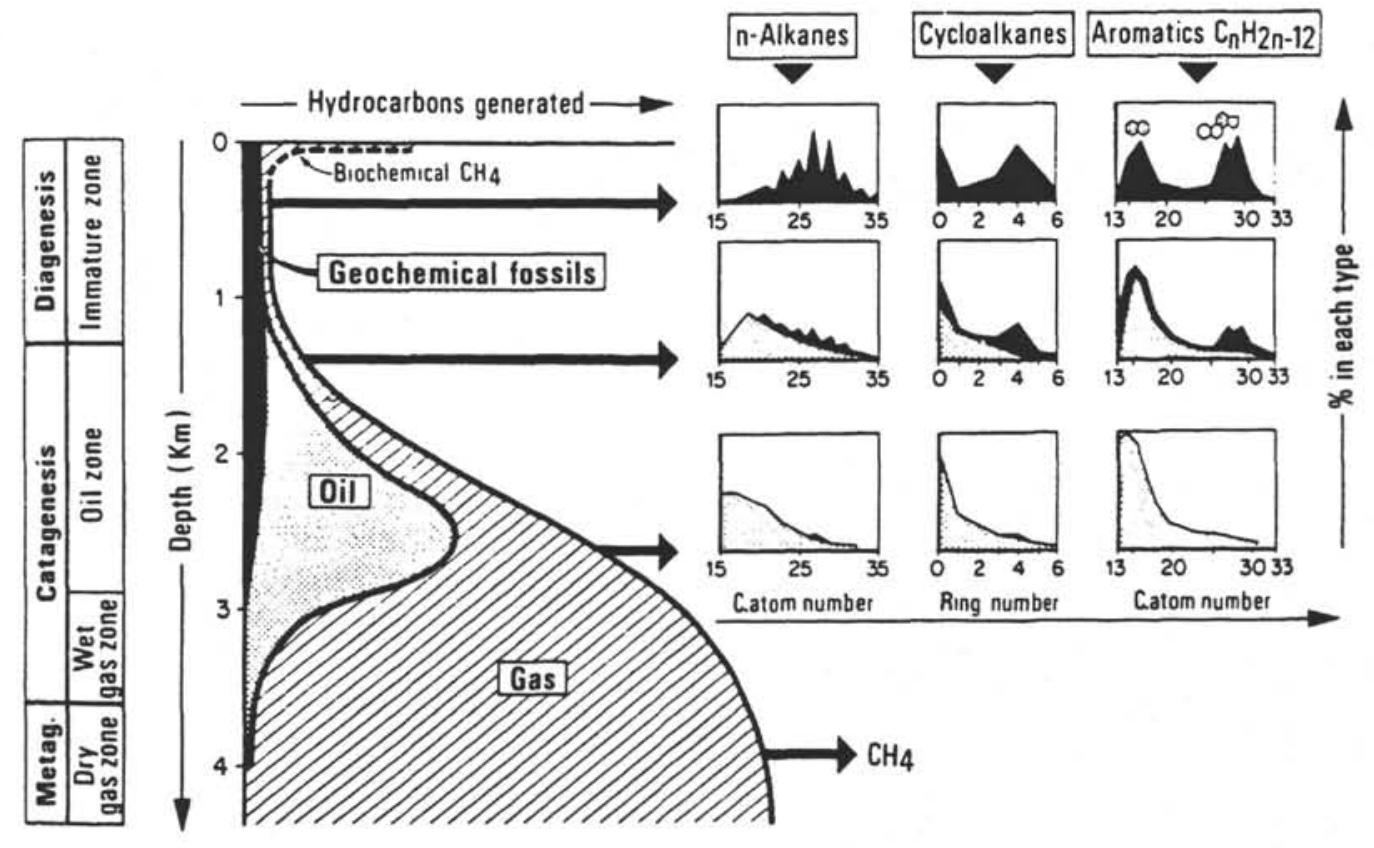

Figure 8. General scheme of hydrocarbon formation as a function of burial of source rocks. Actual depths vary according to particular geological situation and heat flow. (From: B.P. Tissot \& D.H. Welte, 1984. Petroleum Formation and Occurrence. Springer, Berlin, Heidelberg, New York, Tokyo, 2nd edition.) 
E. PYROLYSIS

The organic geochemist and chemistry technicians should operate the Rock-Eval pyrolysis instrument in close coordination with drilling to obtain significant data for evaluation of potential hazards. For example, Rock-Eval pyrolysis can provide preliminary information on the stage of petroleum genesis, petroleum potential and whether migration has taken place.

\section{Procedure}

Rock-Eval pyrolysis is used to rapidly identify the type and maturity of organic matter in whole rock samples. Samples of ground rock, about 100 $\mathrm{mg}$, are pyrolyzed in a helium atmosphere at $300^{\circ} \mathrm{C}$ for $3-4$ minutes, followed by programmed pyrolysis at $25^{\circ} \mathrm{C} / \mathrm{min}$ to $550^{\circ} \mathrm{C}$. Analysis time per sample is about 30 minutes including TOC determination and cooling. Automatic sampling allows for serial analyses of 24 samples. Figure 9 shows the flow schematic in the Rock-Eval, where helium is used as the carrier gas.

The $S_{1}$ and $S_{2}$ peaks are detected by the FID (Flame Ionization Detector), ' whereas the $\mathrm{S}_{3}$ peak from thermal cracking of kerogen is detected by a TCD (Thermal Conductivity Detector) after entrapment of $\mathrm{CO}_{2}$. The $\mathrm{S}_{1}$, $\mathrm{S}_{2}$, and $\mathrm{S}_{3}$ peaks are determined while the sample is in the first oven (the oven on the left). The sample is heated in a temperature program to release free hydrocarbons and subsequently liberates hydrocarbons from cracking of kerogen. In the second oven the sample is oxidized in an oxygen atmosphere to give a reading for Total Organic Carbon (TOC). All of the inorganic carbon has burned off below $600^{\circ} \mathrm{C}$ in the first oven. The TOC is analyzed using the $\mathrm{CO}_{2}$ trap and the TCD in the TOC module. Figure 10 shows a typical Rock-Eval trace.

2. Guide for interpretation of Rock-Eval results

The parameters resulting from Rock-Eval pyrolysis are as follows:

$T_{\max }\left({ }^{\circ} \mathrm{C}\right):$ The temperature at which maximum release of hydrocarbons from cracking of kerogen during pyrolysis occurs (peak of $\left.\mathrm{S}_{2}\right)$.

$\mathrm{S}_{1}$ (mg hydrocarbon/g rock): The quantity of free hydrocarbons (oil and gas) present in the rock and which are volatilized below $300^{\circ} \mathrm{C}$.

$\mathrm{S}_{2}$ (mg hydrocarbon/rock): This peak gives the amount of hydrocarbon type compounds produced by the cracking of kerogen as the temperature increases to $550^{\circ} \mathrm{C}$. This also shows the quantity of hydrocarbons which could be produced in this rock should burial and maturation continue.

$\mathrm{S}_{3}$ (mg $\mathrm{CO}_{2} / \mathrm{g}$ rock): Quantity of $\mathrm{CO}_{2}$ produced from pyrolysis of the organic matter in the rock up to $390^{\circ} \mathrm{C}$. 


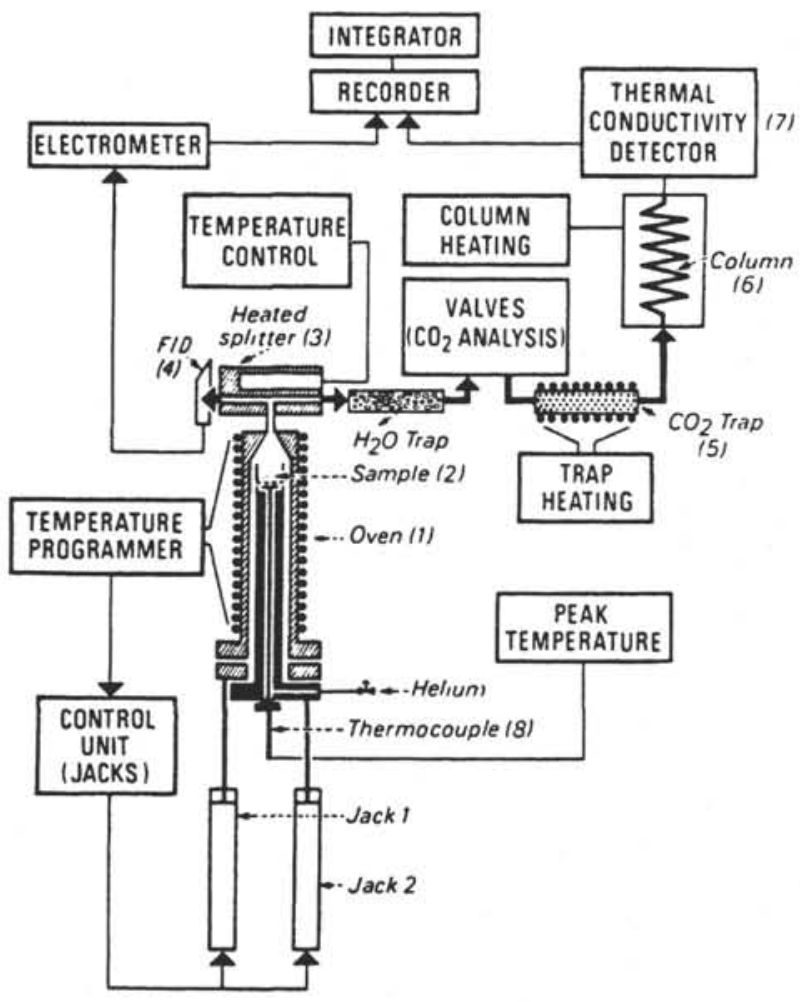

Figure 9. Schematic diagram of Rock-Eval pyrolysis device. From: Tissot \& Welte (1984). Petroleum Formation and Occurrence. Springer, Berlin, Heidelberg, New York, Tokyo, 2nd edition. 


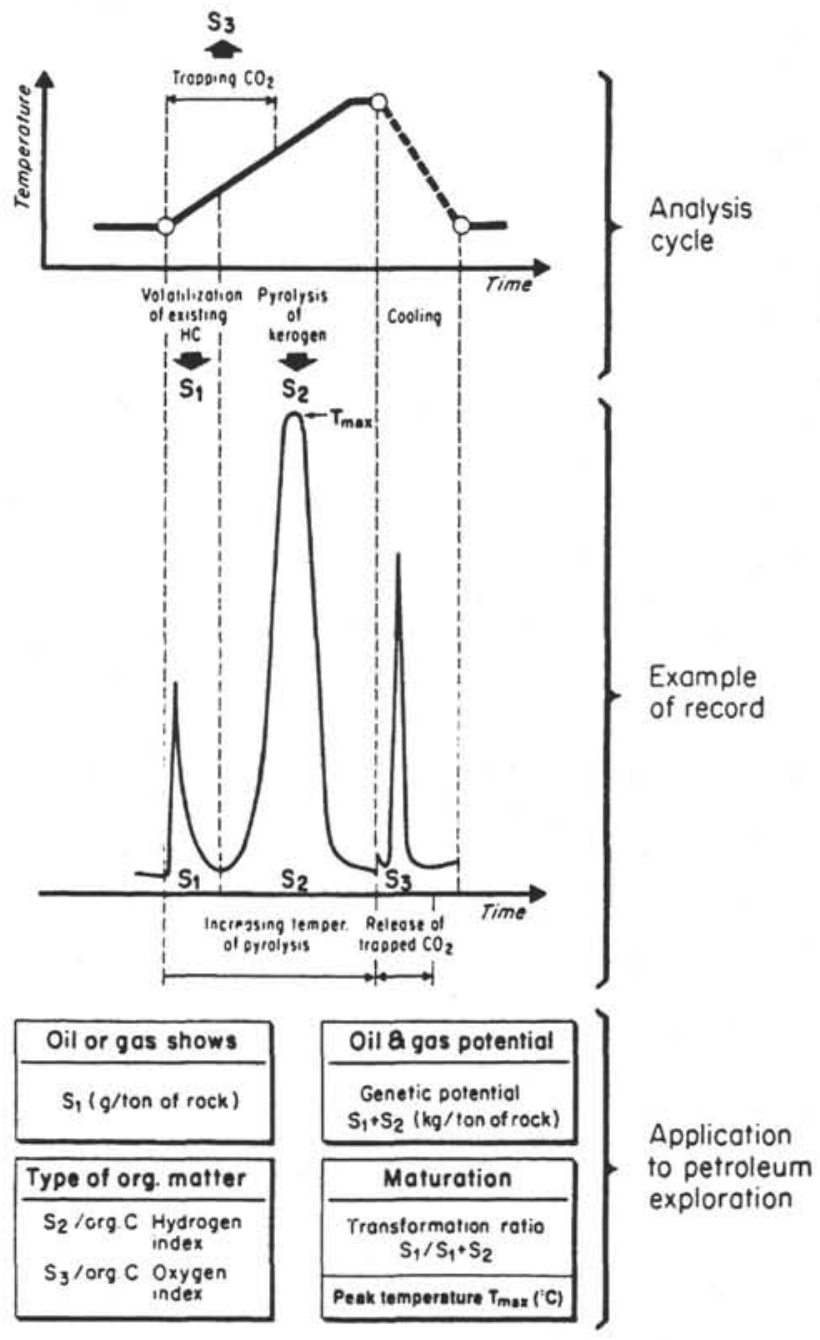

Figure 10. Example of a Rock-Eval trace. From: Tissot \& Welte (1984). Petroleum Formation and Occurrence. Springer, Berlin, Heidelberg, New York, Tokyo, 2nd edition. 
PRODUCTIVITY INDEX (PI): $=\mathrm{S}_{1} /\left(\mathrm{S}_{1}+\mathrm{S}_{2}\right)$. PI characterizes the
evolution level of the organic matter ("See Oil Shows"
below). PI typically increases with depth and can therefore
pinpoint areas with above or below average presence of
hydrocarbons. $\mathrm{S}_{2} / \mathrm{S}_{3}: \mathrm{A}$ means of determining the type of organic matter in the rock
(See "Type" below).

PETROLEUM POTENTIAL $(P C):=k\left(S_{1}+S_{2}\right)$, where $k=0.083 \mathrm{mg}$ carbon $/ \mathrm{g}$ rock. Pyrolyzed carbon ${ }^{1}(P C)^{2}$ corresponds to the maximum quantity of hydrocarbons capable of being produced from the source-rock given sufficient burial depth and time.

TOTAL ORGANIC CARBON (TOC): Weight percent of organic carbon can be determined independently and entered into the program or the TOC module can determine the TOC.
HYDROGEN INDEX $(\mathrm{HI}):=\left(\begin{array}{lll}100 & \mathrm{X} & \mathrm{S}_{2}\end{array}\right) / \mathrm{TOC}$. Is a parameter used to characterize organic matter as to its origin. Marine organisms and algae in general are composed of lipid-and protein-rich organic matter, where the ratio of $\mathrm{H}$ to $\mathrm{C}$ is higher than in the carbohydrate-rich constituents of land plants. HI typically ranges from about 100 to about 600 in geological samples.

OXYGEN INDEX $(\mathrm{OI}):=\left(100 \times \mathrm{S}_{3}\right) / \mathrm{TOC}$. Indirectly determines the ratio of $O$ to $C$, which is high for polysaccharide-rich remains of land plants and inert organic material (residual organic matter) encountered as a background of $C$ in most marine sediments. Values range from near zero forgabout 150 . The classification of different kerogen types according to their HI/OI characteristics is depicted in Figure 11.

Using the parameters shown in Table 3, one can assess the possible type, maturation and oil shows of the rock.

TYPE: Plotting HI against OI, as in Figure 11, provides a guide to three types of organic matter.

This diagram is similar to the familiar Van Krevelen Diagram, which was atomic $\mathrm{H} / \mathrm{C}$ and $\mathrm{O} / \mathrm{C}$ ratios in kerogen to distinguish between different types of organic matter.

Type I: algal, oil prone (lipid- and protein-rich)

Type II: marine, oil/gas prone (intermediate)

Type III: terrestrial, gas prone (lignin-rich)

$$
\begin{aligned}
& \mathrm{S}_{2} / \mathrm{S}_{3}: 0.0-2.5=\text { gas, Type III } \\
& 2.5-5.0=\text { oil/gas, Type III } \\
& 5.0-10.0=\text { oil, Types I and II }
\end{aligned}
$$




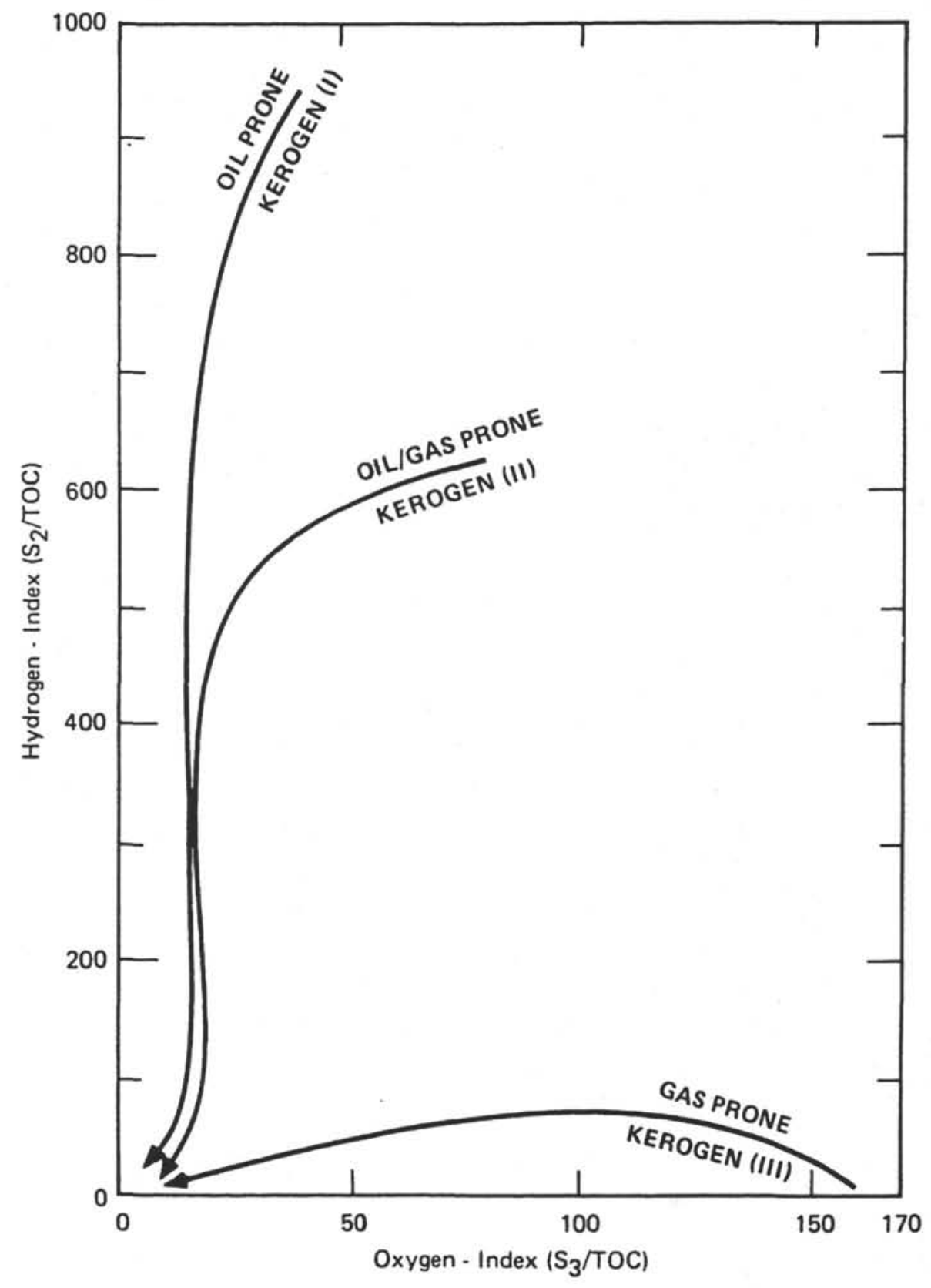

Figure 11. HI/OI plot from Rock-Eval pyrolysis data. This is an adapted version of the so-called Van Krevelen diagram, relating chemical characteristics of organic matter in sediments to origin of organic matter, maturity, and type of hydrocarbons produced. 
Table 3: A sample printout of Rock-Eval parameters which are described in the text.

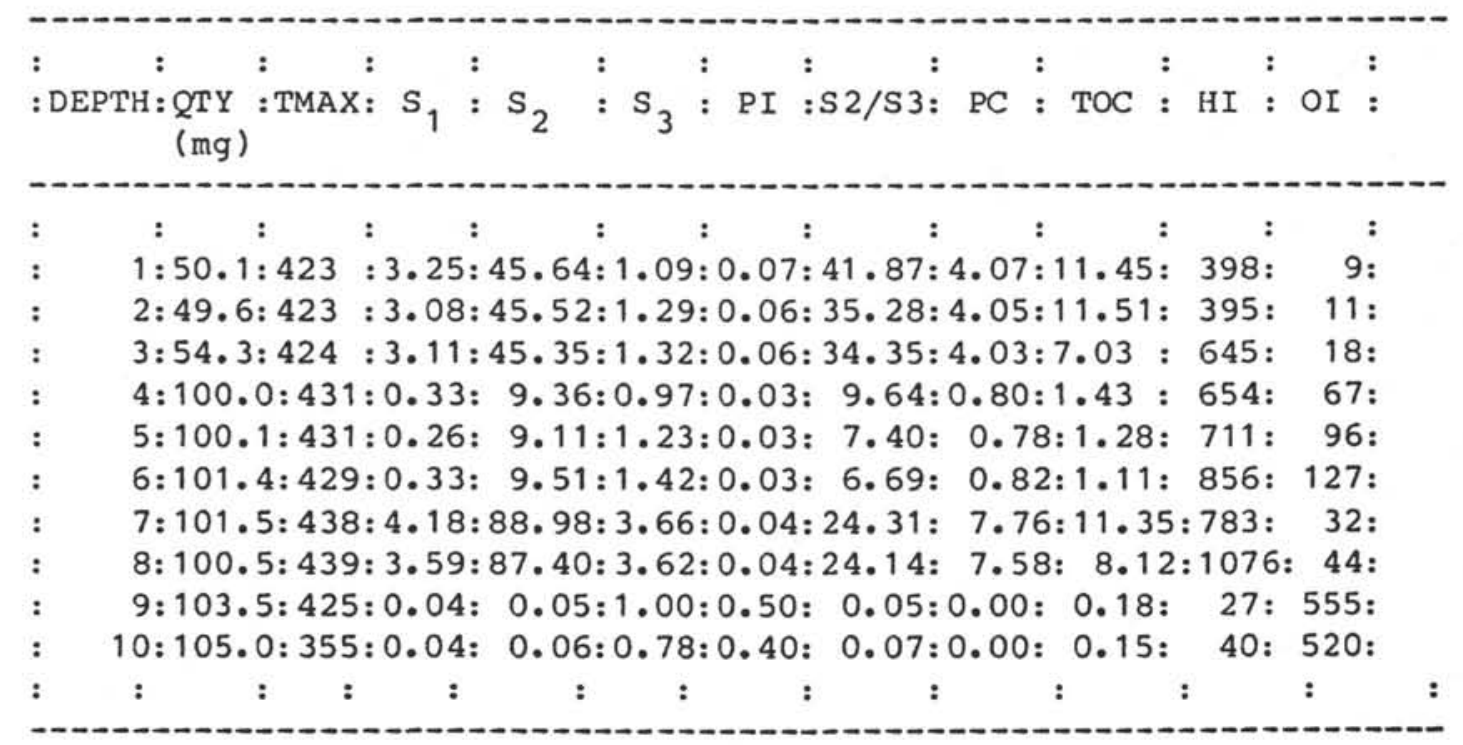


MATURATION: There are three ways to estimate maturation:

1. Location of $\mathrm{HI}$ and OI on diagram in Fig.11. The arrows point towards increasing maturation.

2. According to parameter $T$ :

$$
\begin{aligned}
& 400^{\circ} \mathrm{C}-430^{\circ} \mathrm{C}=\text { Immature } \\
& 435^{\circ} \mathrm{C}-450^{\circ} \mathrm{C}=\text { Mature or Oil Zone } \\
& 450^{\circ} \mathrm{C}-470^{\circ} \mathrm{C}=\text { Gas Zone }
\end{aligned}
$$

3. PI:

In an ideal situation with increasing burial depth, $\mathrm{S}$, should increase and $\mathrm{S}_{2}$ should decrease; thus the PI will increase with depth and maturation.

OIL SHOWS: PI will increase regularly with depth (Fig. 12a) and increase rapidly in zones of hydrocarbon accumulation (Fig. $12 \mathrm{~b})$.

Interpretation of Rock-Eval data must be done cautiously and several pitfalls of the method need to be taken into account:

Quantity of Organic Matter (TOC)

Rock-Eval II with TOC Module yields very good data in samples of relatively low maturity $(<1 \% \mathrm{R})$. Comparison with various combustion methods showed that Rock-Eval data are quite accurate (G. Claypool, pers. comm. 1985). Because of the relatively low combustion temperature, very mature organic matter may not be oxidized to $\mathrm{CO}_{2}$, and values will be too low.

Type of Organic Matter: HI versus OI

Results should be verified by independent methods (maceral microscopy, kerogen investigation etc.). Immature sediments frequently show poor correlation between $\mathrm{HI}$ and atomic $\mathrm{H} / \mathrm{C}$ and OI and atomic O/C. Very often, samples plotted on the HI/OI plot fall in between the general paths, or outside the range of the three major kerogen types. A fourth kerogen path below type III has been suggested by various authors in order to describe highly oxidized, residual organic material.

Thermal Maturity of Organic Matter

$$
\begin{aligned}
& \mathrm{T}_{\max } \text { and the production Index (PI) are rough measurements of maturity } \\
& \text { only. maxpe of OM appears to affect the values. } \\
& \text { Levels of thermal maturation are given by PI plus } \mathrm{T}_{\max } \text { as follows: } \\
& \text { Immature }
\end{aligned}
$$

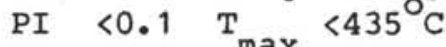

$$
\begin{aligned}
& \text { Onset of oil generation PI } 0.1 \quad \mathrm{~T}_{\max }^{\max } 435-445^{\circ} \mathrm{C} \\
& \text { Oil window } 0.4 \max 445-470^{\circ} \mathrm{C}
\end{aligned}
$$

\section{Bitumen Content}

$\mathrm{S}_{1}$ is an independent measure of the amount of bitumen in a sample although it does not necessarily correlate to solvent-extractable bitumen. 


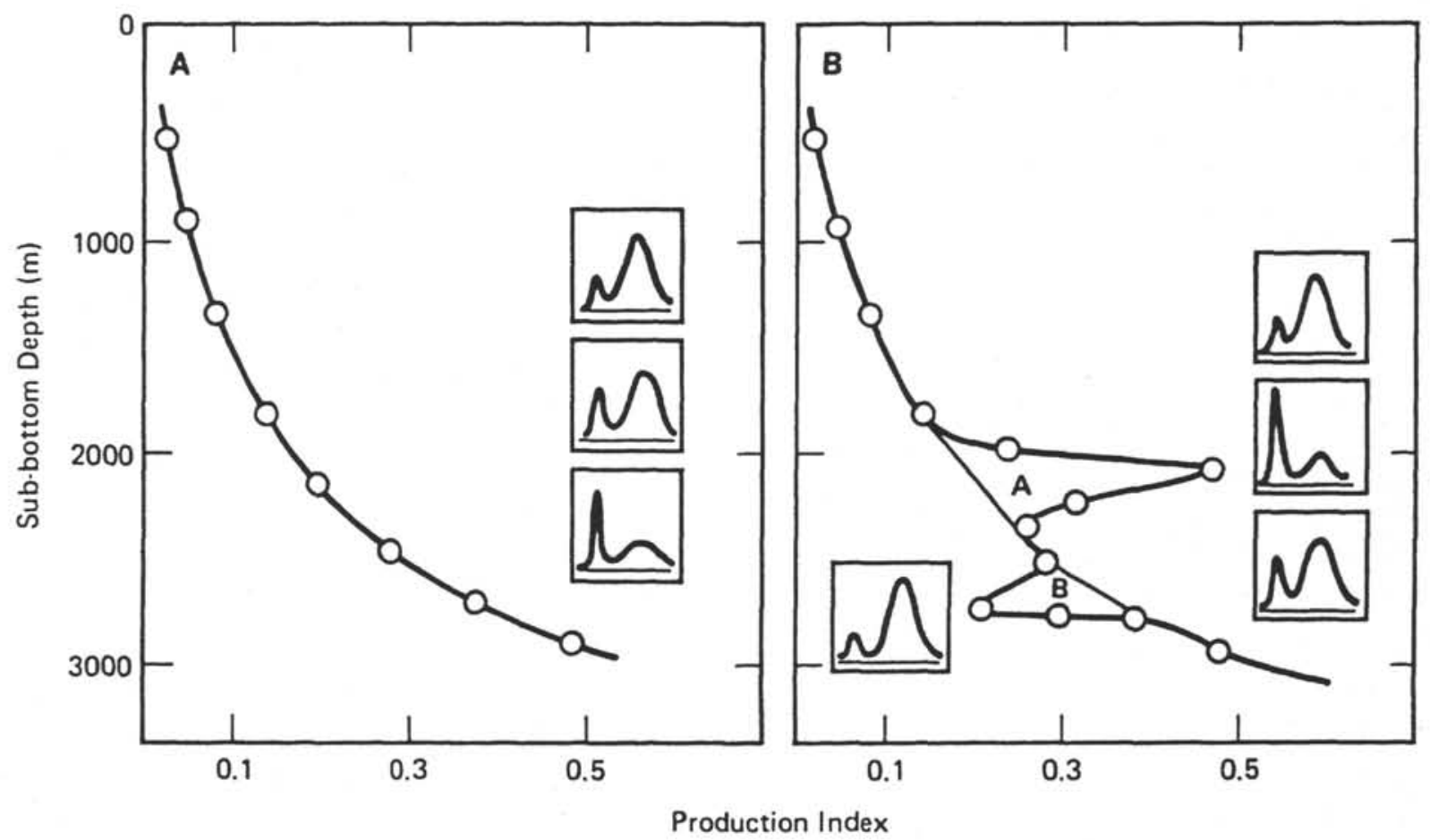

Figure 12. Productivity Index (PI) derived from Rock-Eval pyrolysis. PI increases smoothly with depth when no migrated hydrocarbons are encountered in the sediments (a). Rapidly increasing PI indicates the presence of migrated hydrocarbons (b). 
Migrated oil contributes to this peak, and heavy oil and tar may influence $\mathrm{S}_{2}$ and $\mathrm{T}_{\max } \cdot$

Interference by mineral matrix of samples low in TOC

For clay-rich rocks with less than $0 . \overline{5 \%} \overline{\mathrm{TOC}}, \overline{\mathrm{HI}}$ values are too low and $T$ too high because of absorbtion phenomena. This is especially true in illixte-rich claystones. Sample sizes should always be the same $(100 \mathrm{mg})$, but even if sample sizes are the same, derived variables $\left(\mathrm{S}_{2} / \mathrm{TOC}\right.$ and $\mathrm{S}_{3} / \mathrm{TOC}$ ) may be quite erroneous.

Further literature on Rock-Eval data interpretation can be found in the citations of Appendix C. 


\section{ACKNOWLEDGMENTS}

This manual represents an extensively revised version of the "Shipboard Organic Geochemistry Guide/Handbook" compiled in 1981 by Bernd R.T. Simoneit. Assistance in the preparation of the revision has been provided by numerous ODP Marine Technicians and staff. D. Marsee provided updates on the bibliography concerning organic geochemistry in DSDP Initial Reports. 


\section{Instrumentation}

The following paragraphs are short descriptions of main instruments available in the laboratory. For more detailed information, refer to the manuals present in the laboratory or ask the technicians onboard ship. Instrumentation is constantly being updated or added to, so these descriptions are necessarily general.

Natural Gas Analyzer (NGA)

The NGA is a special option (Option 820) for the H-P 5890A gas chromatograph. The system employs three columns and appropriate automatic valve switching to provide a complete and rapid determination of oxygen, nitrogen, methane, carbon dioxide, ethane, propane, the butanes, the pentanes, and the total hexane+ $\left(C_{6+}\right)$ hydrocarbons. The method may be

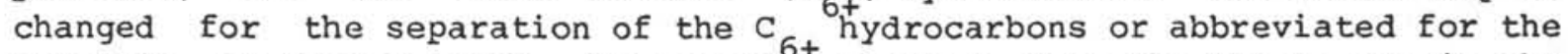
analysis of "lean" gases. We sugges $t^{+}$, however, that the NGA be run in the standard gas analysis mode and that the other H-P 5890A gas chromatograph be used for capillary gas chromatography. The NGA is controlled by the keyboard on the front right side of the GC. This keyboard controls the temperature settings of the ovens, detectors, and injection ports, along with the signal settings such as ranges and signal outputs. The manual located near the instrument gives details on programming the instrument, and a card located on the left side of the GC in the side door provides a quick reference to the control panel. Control of the three valves is accomplished by using the H-P 3392 Integrator. The NGA is interfaced through LAS to the H-P-1000 mainframe computer. This computer accepts raw data from the $G C$ and stores these data in a result file unique to that sample. This procedure permits different analyses of data from the same sample and provides the capability to plot the file on an H-P 7470A

Plotter. Example chromatograms are shown in Figure 13.

\section{Hewlett-Packard $\underline{590 \mathrm{~A}}$ Gas Chromatograph}

This instrument provides numerous choices among inlets, columns, and detectors through inlet lines and adapters. Packed or capillary columns can be used without sacrificing performance. This instrument is mainly for high-resolution gas chromatography. There are two detectors, flame ionization (FID) and thermal conductivity (TCD), and two inlet ports. Either detector can be used with packed or capillary columns. Gas chromatographic peaks are integrated on an H-P 3392 integrator and on LAS.

The high-resolution capillary capability permits real time evaluation of heavy hydrocarbons. The columns available on the ship are H-P Ultra performance capillary columns $(0.20 \mathrm{~mm}$ internal diameter) coated with a 0.11 thickness of cross linked methyl silicone. A typical injection volume is 2 microliters. An example chromatogram (FID) of a standard mixture is shown in Figure 14. 

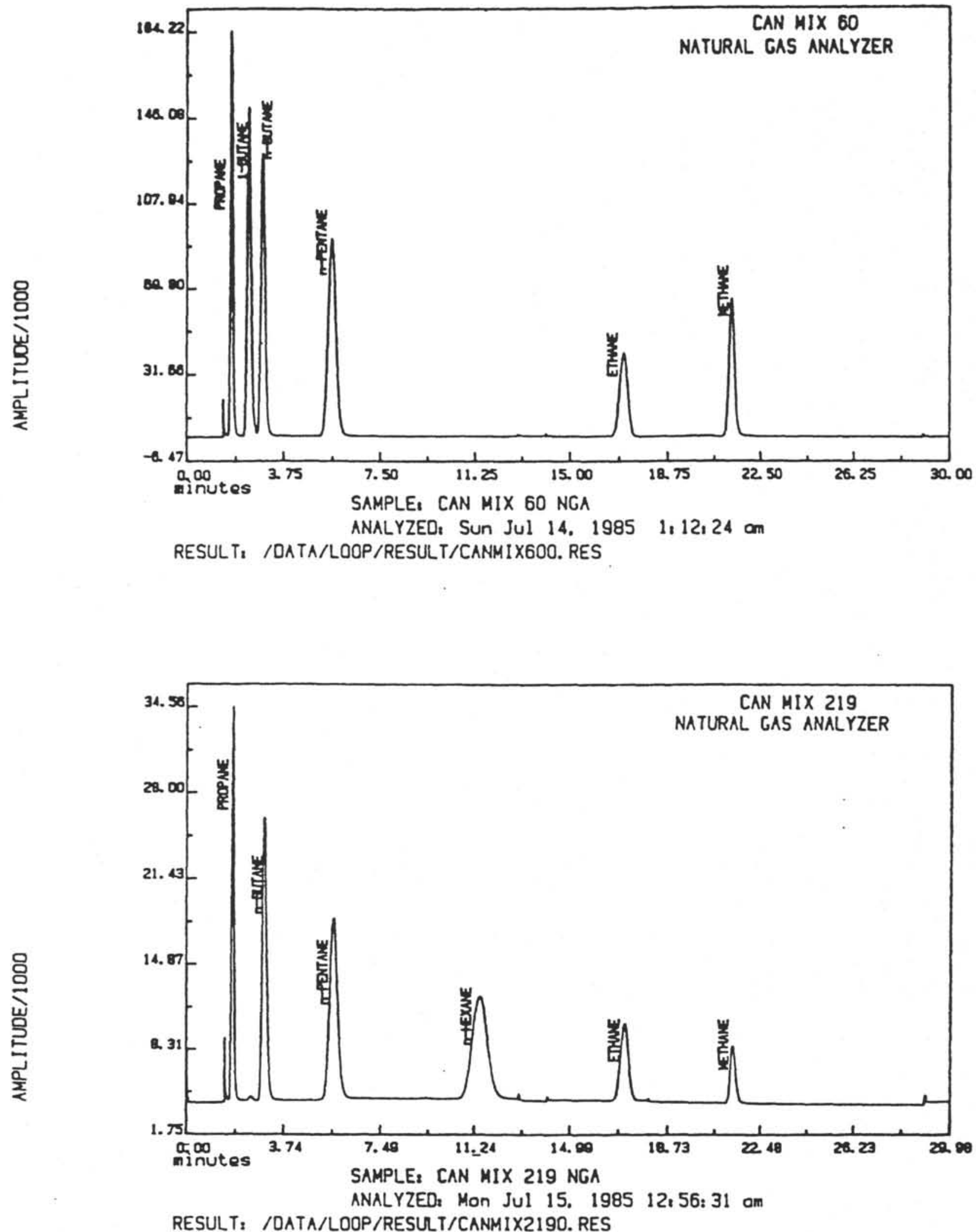

Figure 13. Example of CPLOT output of a standard gas sample analyzed with the Natural Gas Analyzer. 


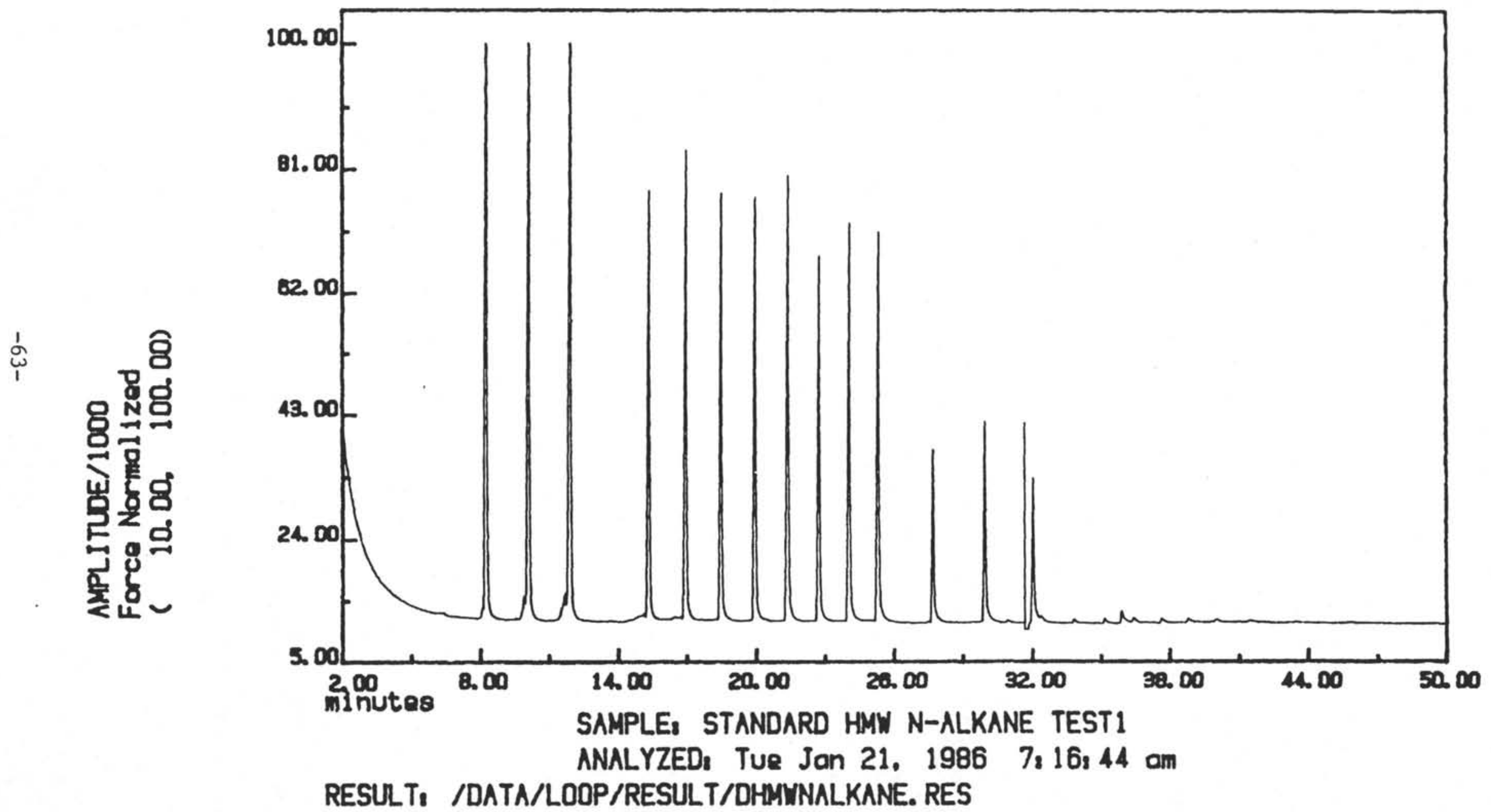

Figure 14. Example of CPLOT output of a standard mixture of n-alkanes analyzed by capillary gas chromatography. 
Chromatographic peaks are integrated as above. The GC conditions for this analysis were shown in table 2 (main text).

\section{Carle Gas Chromatograph}

This instrument is a basic gas chromatograph which produces rapid analyses of gas up to molecular weight $\mathrm{C}_{3+^{-}}$. In contrast to the more sophisticated NGA, it is intended to be the workhorse for on-line safety monitoring. The instrument is controlled and results are computed by a HP integrator. At the time of writing, the instrument underwent its first trial, and we do not have any information on performance.

\section{Laboratory Automation System (LAS)}

LAS is the software system that accepts digital data from the gas chromatographs and ion chromatographs. This system has been designed to help process the generated data into both tables and chromatographic plots. The software is used in a screen dialog mode; the user controls the program with a pointer and 8 soft keys. LAS stores the acquired digitized data from each chromatographic run in a unique result file as designated by the operator. Methods are set up to analyze the raw data; these methods are used to name peaks, to determine concentrations based on areas of individual peaks, to calculate total sample concentration, and to store this information in a processed file which can be used in CPLOT.

\section{Chromatographic Plotting Program (CPLOT)}

CPLOT is a comprehensive chromatogram plotting program for use with the LAS system. CPLOT allows the manipulation of the collected data to enhance or suppress the signal, to analyze a chosen time window, and to calculate area. CPLOT is controlled through 8 soft keys, 3 main menus, and 10 specialty menus. Only LAS result files and method files may be used in CPLOT. With this system raw data are never lost, and they can be plotted in numerous ways. Figures 13 and 14 were generated utilizing CPLOT.

Rock-Eval II with TOC

Rock-Eval is a whole rock or sediment pyrolysis system used to ascertain the type and maturity of organic matter and to estimate petroleum potential. The pyrolysis technique involves a microprocessor controlled temperature program that causes the release of the light-end hydrocarbons (oil/gas shows), recorded as a peak called $s_{1}$, and the release of hydrocarbon by thermal cracking of the kerogen matrix producing peak $\mathrm{S}_{2}$. During the pyrolysis of the sediment $\mathrm{CO}_{2}$ produced from pyrolysis of kerogen is indicated as peak $\mathrm{S}_{3}$, and is trapped only between the initial starting temperature and $390^{\circ} \mathrm{C} ;{ }^{3}$ this trapping avoids other sources of $\mathrm{CO}_{2}$ such as carbonate, especially siderite which is the most labile carbonate. $\mathrm{A}$ fourth parameter is $T_{\max }$ which is the pyrolysis temperature at which the $S_{2}$ peak 
reaches a maximum. In a second oven, the total organic carbon (TOC) is measured by combustion in an oxygen atmosphere. Rock-Eval automatically prints the results on a pyrogram (text, Fig. 9), in a data table (text, Table 3), and in a bar graph.

A series of standards with a wide range of maturity and organic carbon concentrations is available in the laboratory. The standard sample size is $100 \mathrm{mg}$. If the samples are very rich in organic matter, a smaller sample size may be used or samples are diluted with quartz sand.

Coulometrics 5030 Carbonate Carbon Apparatus, 5020 TC Apparatus and components for liquid samples

The Coulometrics carbon analyzer rapidly and accurately determines $\mathrm{CO}$ from a variety of sources. The Coulometrics Model $5010 \mathrm{CO}_{2}$ Coulometer, which is the detector for the Carbonate Carbon Apparatus, is filled with ethanolamine and an indicator. When gas is passed through the solution, $\mathrm{CO}_{2}$ is quantitatively absorbed and is converted to a strong acid by the ethanolamine. The coulometer electrically generates a base to return the indicator color to the starting color. Results for carbonate carbon are given in micrograms of carbon and percent $\mathrm{CaCO}_{3} \cdot \mathrm{CO}_{2}$ is generated by treatment of the sediment with $\mathrm{HCl}$ and gentle heating; the evolved $\mathrm{CO}_{2}$ is transferred to the coulometer by a purified air stream. Analysis time is 3 to 7 minutes. For TC measurements, the sample is combusted at $950^{\circ} \mathrm{C}-1000^{\circ} \mathrm{C}$, converting mineral and organic carbon to $\mathrm{CO}_{2}$. Interfering gases $\left(\mathrm{SO}_{2}, \mathrm{SO}_{3}\right.$ ' NO etc.) are removed by a series of chemical scrubbers. Both total carbon (by combustion at $950^{\circ} \mathrm{C}$ after direct injection) and inorganic carbon (by acidification to $\mathrm{pH} 2$ ) can be determined in liquid samples (pore waters). organic carbon content for solid and liquid samples is computed by difference.

Perkin Elmer CHN $=\underline{\text { ELEMENTAL }}$ ANALYZER

The model 240C Elemental Analyzer determines carbon, sulfur, and nitrogen in sediment samples, as well as $\mathrm{H}, \mathrm{C}$, and $\mathrm{N}$ concentrations in kerogen extracts prepared by $\mathrm{HF}$ digestion of sediments or organic substances. Samples are combusted at approximately $950^{\circ} \mathrm{C}$ in pure oxygen; the combustion products are then trapped and successively quantified in a thermal conductivity detector. Quantitative results are obtained by calibration with appropriate standards. The analysis of $\mathrm{H}$ in sediments is not possible, because hydrated clay mineral interlayers release $\mathrm{H}_{2} \mathrm{O}$ during combustion which is recorded as $\mathrm{H}$. 


\section{Data Sheets}

Results of geochemical mexsurements are recorded onboard ship on data sheets. These are used after the cruise to enter results into the computer by shorebased personnel, thereby establishing a data base accessible to the entire scientific community. Recording of results and methods usually is performed by the Chemical Technicians at the termination of analyses for one hole. The following are samples of these data sheets for $\mathrm{CaCO}_{3}, \mathrm{CHN}$ analyses, Rock-Eval pyrolysis, and gas chromatography. 


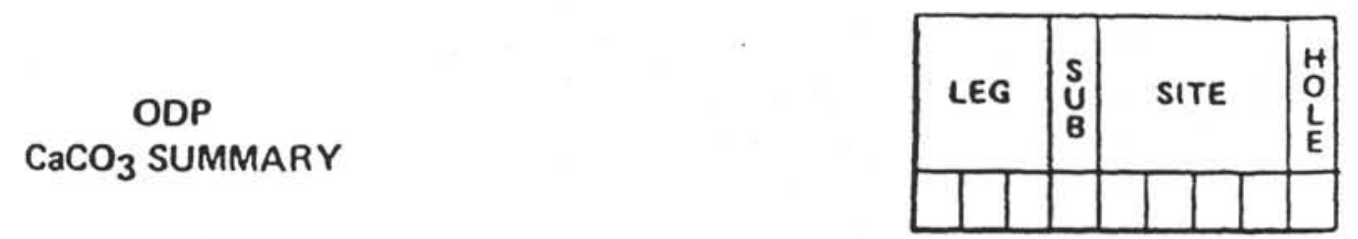

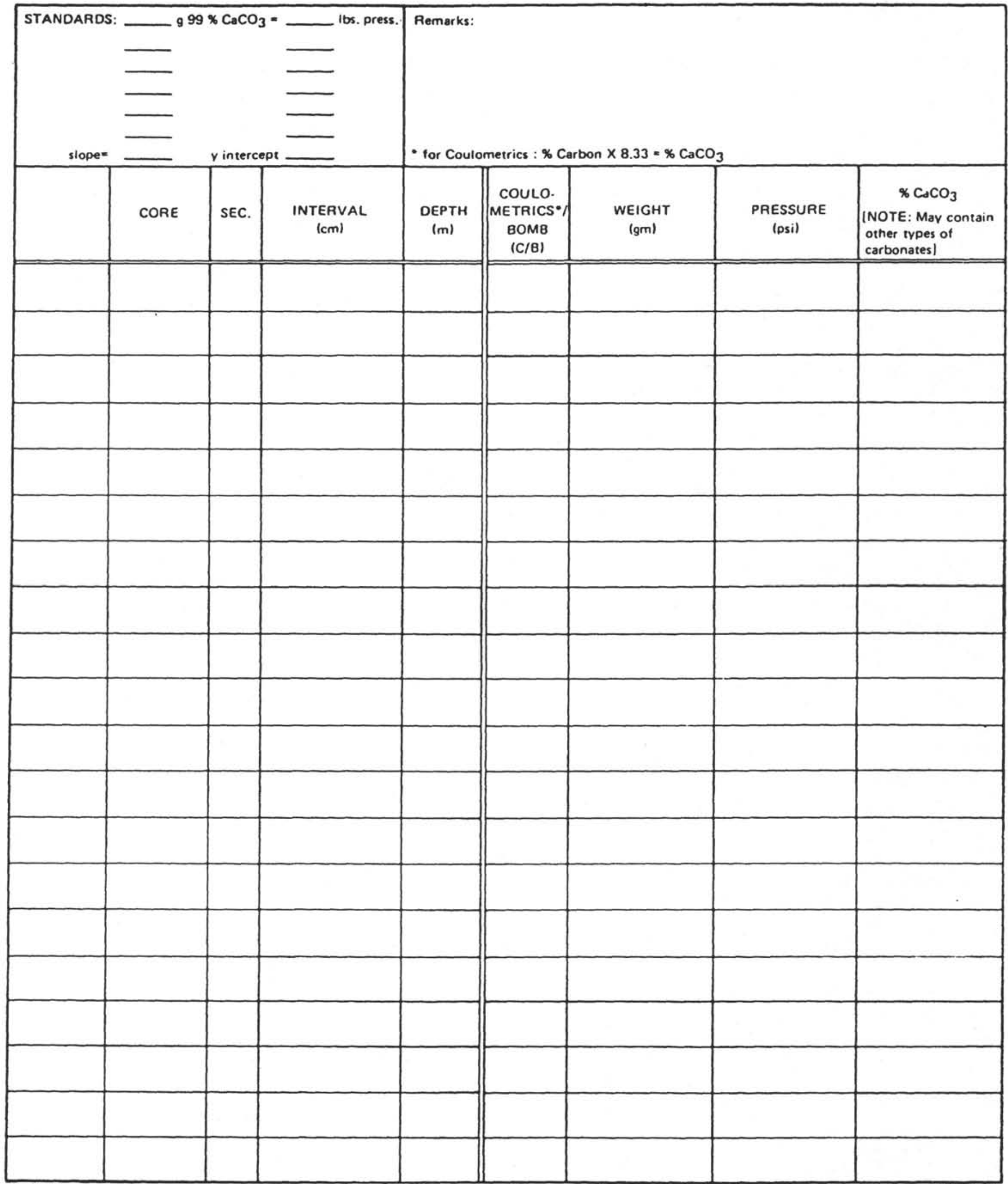

These data will be processed into a computerized data bose along with existing standardized data from other legs and will be accessible to the scientific community at large. AECORD MEASUREMENTS CAREFULLY. COMPLETELY. AND LEGIBLY. 
ODP

CHN SUMMARY

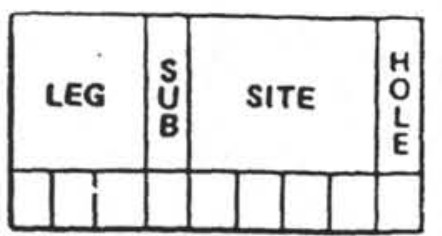

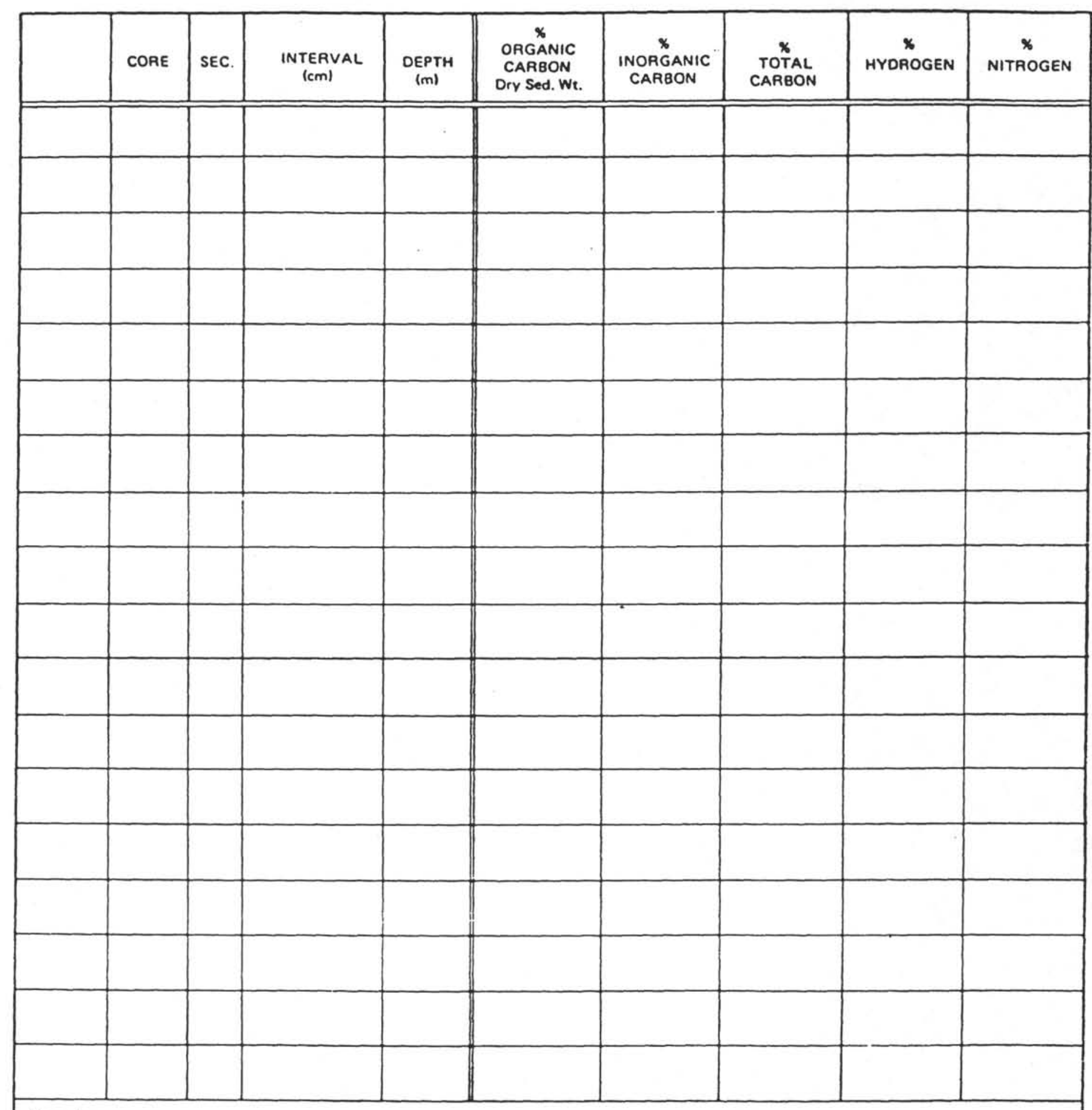

Remarks

\%Orgenic Carbon, Dry Sed. wt. $-[100-\% \mathrm{CaCO} 3 \times \%$ Orgenic Cerbon (Carbonate free, from $\mathrm{CHN})] / 100$

XInorgenic carbon - Total Corbon (from CHN) - *Orgenic Carbon (from CHN)

Xinorganic Carbon $\times 8.33$ - \%Calcium Carbonate

These dats are to be processed into a computerized dalo bese along with existing standardized data from other legs and will be accessible to the scientitic community ot large. RECORO ALL MEASUREMENTS CAREFULLY. COMPLETELY. ANO LEGIBLY. 
ROCK EVALUATION SUMMARY

\begin{tabular}{|c|c|c|}
\hline LEG & $\begin{array}{l}\mathbf{S} \\
\mathbf{U} \\
\mathbf{B}\end{array}$ & SITE \\
\hline & & \\
\hline
\end{tabular}

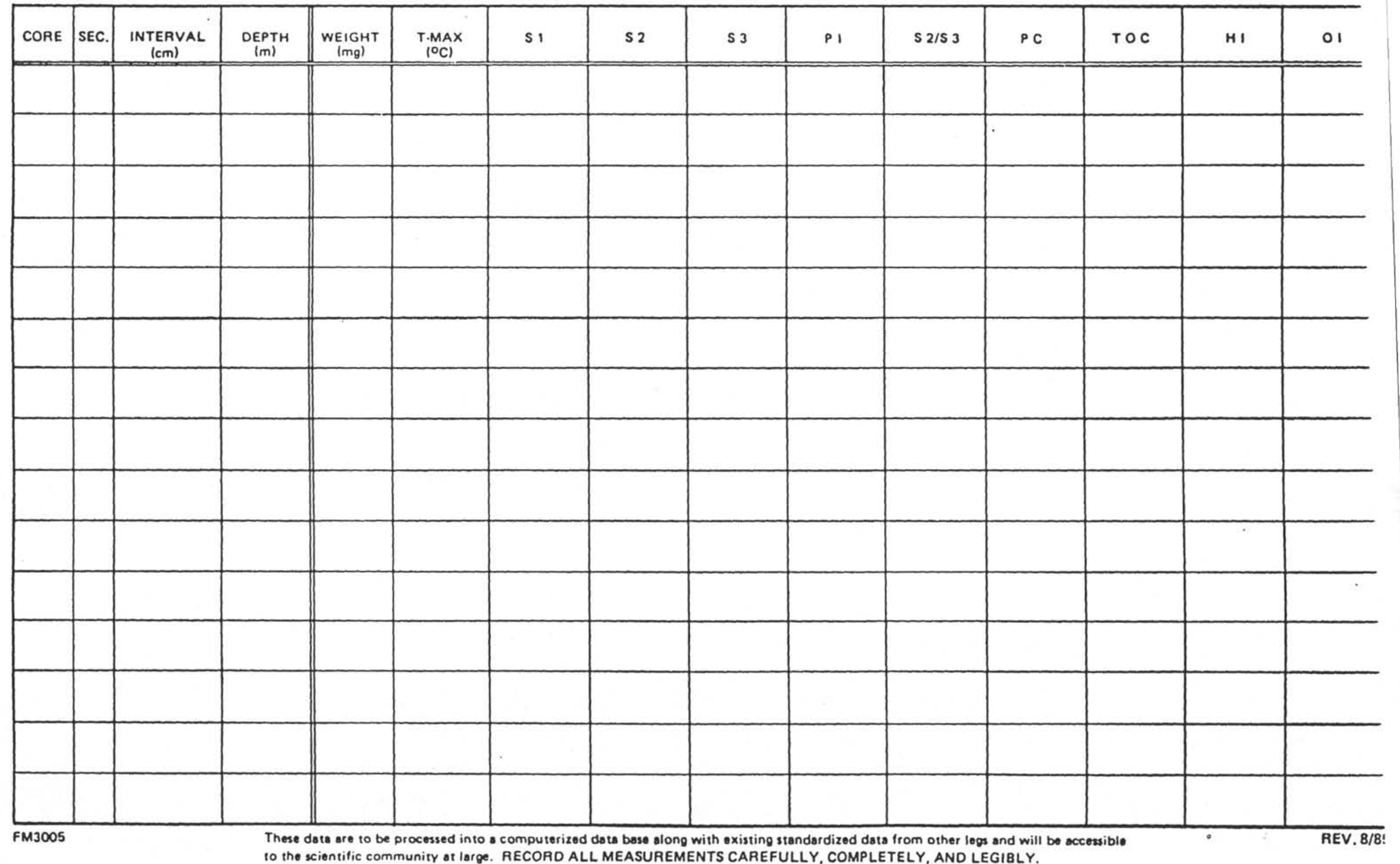


GAS CHROMATOGRAPHY

\begin{tabular}{|c|c|c||l|l|}
\hline & \multicolumn{2}{|c||}{$F I D$} & \multicolumn{2}{c|}{ TCD } \\
\hline & AREA COUNTS & PPM & AREA COUNTS & PPM \\
\hline \hline $\mathrm{C}_{1}$ & & & & \\
\hline $\mathrm{C}_{2}$ & & & & \\
\hline $\mathrm{C}_{3}$ & & & & \\
\hline $\mathrm{NC}_{4}$ & & & & \\
\hline $\mathrm{IC}_{4}$ & & & & \\
\hline $\mathrm{NC}_{5}$ & & & & \\
\hline $\mathrm{IC}_{5}$ & & & & \\
\hline $\mathrm{NC}_{6}$ & & & & \\
\hline $\mathrm{IC}_{6}$ & & & & \\
\hline $\mathrm{H}_{2} \mathrm{~S}$ & & & & \\
\hline $\mathrm{CO}_{2}$ & & & & \\
\hline $\mathrm{O}_{2}$ & & & & \\
\hline $\mathrm{N}_{2}$ & & & & \\
\hline $\mathrm{C}_{1} / \mathrm{C}_{2}$ & & & & \\
\hline & & & & \\
\hline & & & & \\
\hline
\end{tabular}

\begin{tabular}{|c|c|c|c|c|c|c|c|c|}
\hline \multirow{2}{*}{ LEG } & \multirow{2}{*}{$\begin{array}{c}\mathrm{S} \\
\mathrm{U} \\
\mathrm{B}\end{array}$} & \multirow{2}{*}{ SITE } & \multirow{2}{*}{\begin{tabular}{|l|l} 
\\
0 \\
$L$ \\
$E$ \\
$E$
\end{tabular}} & \multirow{2}{*}{ CORE } & \multirow{2}{*}{\begin{tabular}{l|l}
$T$ \\
$Y$ \\
$P$ \\
$E$ \\
\end{tabular}} & \multirow{2}{*}{ SEC } & \multicolumn{2}{|c|}{ INTERVAL } \\
\hline & & & & & & & TOP & $\overline{\text { BOTTI }}$ \\
\hline & & & & & & & & \\
\hline
\end{tabular}

\begin{tabular}{ll}
\hline \multicolumn{1}{l}{ CONDITIONS } \\
Helium Pressure & Range \\
Hydrogen Pressure & Detector Temp. TCD \\
Air Pressure & Detector Temp. FID \\
Initial Temperature & Sample Amount \\
Final Temperature & Loop Size \\
Column Pressure & Date \\
Injection Temp. TCD & Time \\
Injection Temp. FID & \\
\hline
\end{tabular}

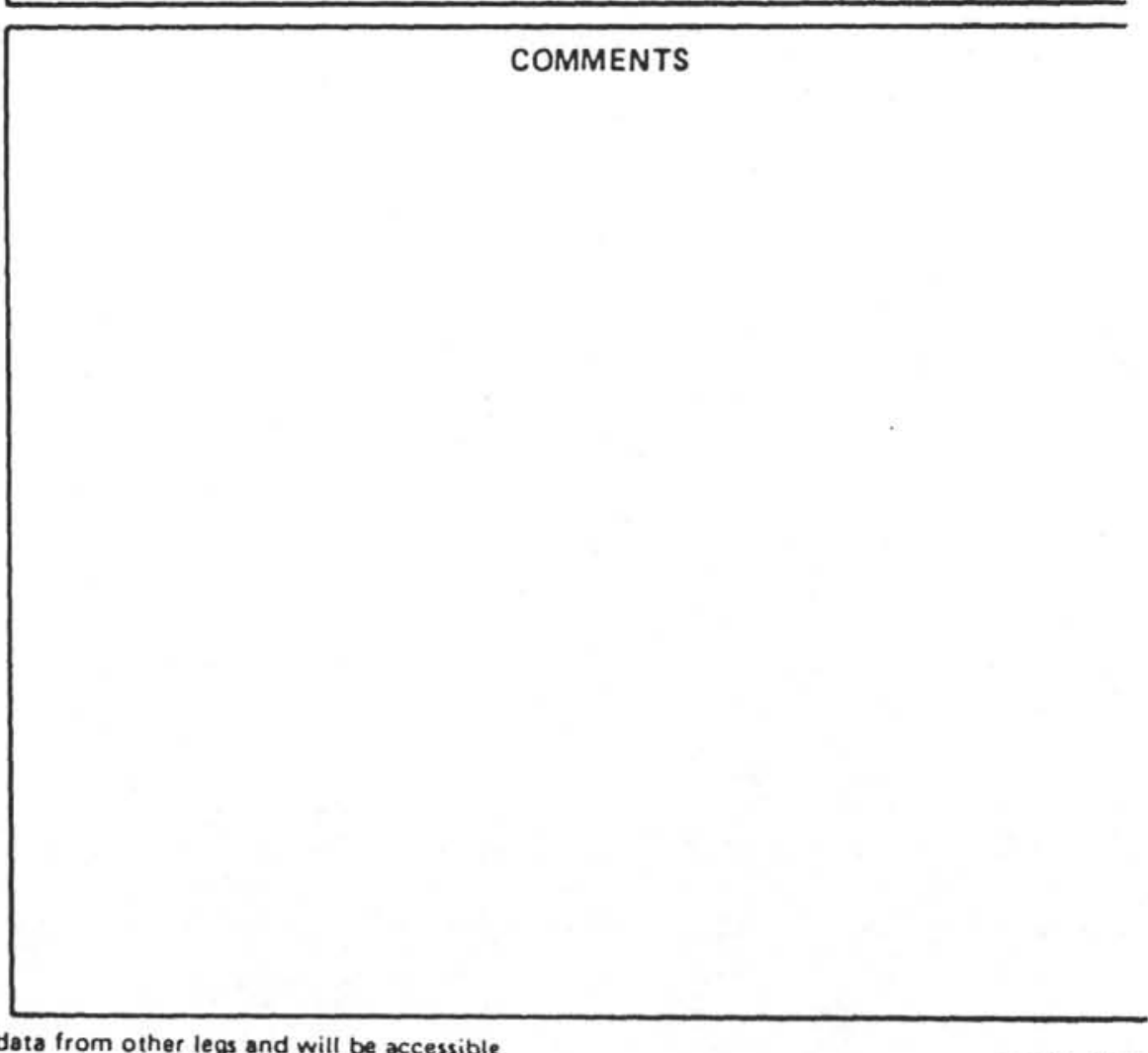


Section 1. Index of Organic Geochenistry Information Published in the DSDP Initial Reports, organized by compound type.

Compound References ${ }^{1}$

\section{ACIDS:}

Carboxylic acids

Hydroxy acids

Branched isoprenoid acids

Naphthenic acids

Normal saturated fatty acids

Cyclic terpenoid acids

Unsaturated acids

\section{ALCOHOLS :}

Normal fatty alcohols

Branched/cyclic
$20,114,144,160,174,194,220$, 229,265

$18,20,144,160,174,229$

$18,20,101,103,105,144,160$, $174,184,194,229$

25,26

$18,51,101,103-109,111-114,125$, $134,138,158,160,174,188,194$, $195,200,201,216,218,220,221$, $229,245,248,264,271,302$

$20,99,101-105,116,125,138,144$, $158,160,188,201,221,229,302$

$18,20,114,144,160,229$

18, 51, 194, 197, 220, 229, 245, 264,271

$106,108,111,174,194,197,220$, $229,231,264$

AMINO COMPOUNDS:

Amino acids

$3-5,50,91,118,119,223,236$

Amino sugars

$50,69,91,226$

Amines

50

$21,27-29,31,32,36,39,40,48$,

ASPHALTENES, ASPHALITICS, NSO: 
$55-57,70,73,76,77,80,89,90$, $92,123,127-130,132,142,151$, $152,157,170,171,181,184,187$, $191,201,211,212,214,218,227$, $233,235,238,239,241,242,246$, $253,255,262,266,273,275,280$, $288,290,293$

ETHERS:

HYDROCARBONS :

Alkanes (saturated)
174

$$
\begin{aligned}
& 1,2,8,18,20,21,23,24,26-33, \\
& 36,38-40,44,46-48,55-61,66,70, \\
& 74-92,94,99-104,106-116,118, \\
& 120,122,123,124,125,127,129, \\
& 130,132,133,134,136,138,139, \\
& 140,142,143,144,145,151,152, \\
& 154,155,156,157,158,160,163, \\
& 165,166,168,169,170,171,172, \\
& 173,174,180,181,184,185,187, \\
& 188,191,194,195,196,197,198, \\
& 200,201,204,206,207,208,210, \\
& 211,212,214,215,216,218,220, \\
& 221,222,227,228,229,232,233, \\
& 237-239,240,241,244,245,246, \\
& 247,248,249,250,251,252, \\
& 253-255,262-264,265,266,269, \\
& 270,271,272,273-275,276,277, \\
& 279,280,287,288,289,290,291, \\
& 292,293,294,296,297,298,299, \\
& 300,301,302,308,310
\end{aligned}
$$

$2,8,18,20,21,23,24,26-33,36$, $36,38-40,44,46-48,55-62,70$, 74-92, 94, 100-114, 116, 118, 120, $123,124,125,129,130,132,133$, $134,136,138,139,140,142,144$, $145,151,152,154,155,156,157$, $158,160,163,166,168,169,170$, $171,172,173,174,180,181,184$, 185, 187, 188, 191, 194, 195, 196, 197, 198, 200, 201, 204, 206, 207, 208 , 210, 211, 212, 214, 216, 218, $220,221,227,228,229,232,233$, 238,239 , 240, 241, 244, 245, 246, $248,249,252,253,255,262,263$, $264,265,266,269,270,271,272$, $273,275,276,277,280,288,289$, $290,291,293,294,296,297,299$, 
$300,301,302,308,310$

$$
\begin{aligned}
& C_{1}-C_{8} \\
& C_{4}-c_{10} \\
& C_{10+} \text { or } C_{15+}
\end{aligned}
$$

Alkenes (unsaturated)

Arcmatic hydrocarbons
$8,23,30,33,46,47,55,60-62$, $78,79,81,83,84,85,86,87,88$, $89,90,92,94,120,124,133,139$, $143,154,155,168,170,172,173$, $196,198,204,206,207,208,210$, $213,228,232,240,246,247$, $249-251,250-252 ， 263 ， 269 ， 279$, 289 , 296, 298, 299, 301, 303, 308, 310

33 , 55, 57-59, 70, 73, 77, 78, 82, $90,124,151,250$

$2,18,20,21,24,27-29,31,32$, $36,38,40,47,48,55-57,70,73$, $74,76-78,80,83,85,89-92$, $100-114,116,118,122,123,125$, $127,129,130,132,134,136,138$, $140,142,144,145,151,152,156$, $157,158,160,163,166,169,170$, $171,174,180,181,184,185,187$, $188,191,194,195,197,200,201$, $211,212,214,216,218,220,221$, $229,233,238,239,241,244-246$, $248,255,262,264,265,270-273$, $275-277,280 ， 290 ， 291,293,294$, 300,302

$2,20,29,101,104,105,11,123$, $127,136,138,142,144,157,160$, $163,173,174,194,197,207,218$, $228,229,238,239,240,255,263$, $265,269,270,272,276,288,289$, 303

$18,21,27-29,31,32,36,39,44$, $48,55-57,61,70,74,77,78,83$, $85,89,92,101,103-105,116,123$, $124,127,129,133,134,138,139$, $142,144,151,152,155,157,158$, $160,163,165,166,170,173,174$, $184,185,187,194,195,198,199$, $200,201,207,209,211,212,214$, $221,227,229,233,238,239,240$, $241,246,250,253,255,262,263$, $265,266,269,270,273,275,277$, $288,290,293,294,299,302$ 
Branched hydrocarbons (Pristane, Phytane, etc.)

Steranes/terpanes

(cyclic)

HUMIC COMPOUNDS:

ISOTOPES:

Carbon

Sulfur

Nitrogen

Hydrogen

Oxygen

KEROGEN:

(includes optical studies)
$2,18,21,29,48,55-57,89,90$, $100-101,103-105,109,111,113$, $116,118,122,123,125,134,138$, $144,145,151,157,158,160,166$, $169,171,174,180,181,184,187$, $188,191,194,195,197,200,201$, $211,212,214,216,218,220,221$, $229,238,239,241,245,248,262$, 264 , 265, 270, 271, 275, 276, 277, $288,290,291,294,300,302$

$2,20,29,99-101,100,103$, $104-106,105,107,108,109,111$, $113,122,134,138,144,145,158$, $160,166,174,182,185,188,194$, 195, 197, 200, 201, 212, 214, 216, $218,220,221,229,239,265,270$, $272,276,290,294,302$

27-29, 53, 105, 116, 118, 123, 127 , 129, 131, 136, 151, 157, 167, 174, $192,213,238,239,241,286,287$

$8,19,23,26,30,33,35-43,46$, $47,49,61,70,77,88,89,92,96$, 97, 101, 103-105, 116, 120, 124, $132,140,145,151,154,156,158$, $168,169,172,181,184,187,191$, $201,208,210,211,216,219,221$, 242, 249-252, 268, 272, 276, 279, $283,296,297-301,310$

$26,34,251,279$

201

$201,210,297,299,310$

$242,279,297,299,310$

$1,2,8,20-22,24,27-29,31,32$, $35-43,47,49,52,53,55,63-68$, $83,85,88,89,95,121,122,123$, $127-131,132,136,140-143,145$, $149,150,151,153,157,158,163$, 
$166,167,169,170,180,192,193$, $196,200,201,205,212,213,214$, 215 , 216, 218, 219, 221, 222, 225, $227,230,233,234,238,239,241$, $244,246,253,254,262,266,267$, $270,272-275,277,280,286,287$, $290,291,293,294,311$

KETONES:

Isoprenoid

Hydroxy

Methyl

Cyclic terpenones

Cyclic sterones

LIPIDS:

PIGMENTS:

Carotenoids

Tetrapyrroles:

Chlorins

Porphyrins

SUGARS:
98, 104, 105, 109, 174, 194, 195, 197,291

229

$104,105,125,134,138,158,174$, 194, 197, 229, 265

$99,104,174,194,216,265$

$108,113,229$

$20,35-43,47,91,92,101-105,116$, 122 , 125, 132, 134, 140, 144, 156, $158,160,169,174,182,185,188$, $194,195,197,201,216,218,220$, $221,229,230,245,264,265,271$, 291,302

20, 174, 175, 176, 199, 209

7 , 9-16, 93, 115, 126, 135, 137, $151,175,176,183,197,199,209$, 211

$6,7,9-13,15,16,26,93,103$, $115,126,135,137,151,159,160$, $176,183,186,194,197,199,209$, 211

$91,117,217,223,226,312$ 
ELEMENTAL ANALYSES:

Sulfur (organic)

Carbon (organic)

Nitrogen

Oxygen

Hydrogen

Furans

Hydrates

Gases

Sumaries

Rock-Eval - Pyrolysis:
$26,34,63,123,127,136,163,192$, $213,215,230,238,251,262,275$, 288

$$
\begin{aligned}
& 122,123,124,125-127,129-135, \\
& 136,140-142,143,145-147,149, \\
& 151-153,155-164,166-171,173-181, \\
& 183-193,196,197,198-202,206, \\
& 207,209,211-216,218,219,221, \\
& 222,223,225,227,229-231,233, \\
& 235,237-248,249,250,253-256, \\
& 258,260-264,266-296,300,305, \\
& 306,307,311,312
\end{aligned}
$$

$$
\begin{aligned}
& 123,127,132,136,140,156,163, \\
& 167,2169,179,181,184,187,192, \\
& 206,213,215,216,218,219,221, \\
& 230,238,239,245,248,250,251, \\
& 253,261,262,263,266,271,273, \\
& 275,279,282,288,291,292,295, \\
& 306,312
\end{aligned}
$$

$123,127,136,143,156,157,163$, $167,192,213,215,230,239,253$, $262,266,273,275,288$

$123,136,143,156,157,158,163$, $167,192,213,215,216,219,221$, $230,238,253,262,266,273,275$, 288,303

173

$228,232,249,250,296-299,301$, 310

170, 196, 208, 228, 232, 249, 250, $252,279,296,297,303$

$54,71-73,121,148,187,192,194$, 203, 224, 257-259, 309

$123,127,136,143,149,150,152$, 157, 163, 191, 193, 200, 212, 213, $215,218,222,225,237,238,239$, 240 , 247, 253, 254, 255, 259, 262, $263,266,270,272,273,274,275$, 
$277,287,288,290,291,292,293$, 294,311

Contaminants

$157,182,265$

${ }^{1}$ See Section 4 of this appendix for full reference citations. 
Section 2. Index of DSDP legs and sites with Organic Geochenical Information.

\begin{tabular}{|c|c|c|c|}
\hline Leg & Sites & Samples & Reference \\
\hline 1 & 2 & 18 & 26 \\
\hline 4 & $\begin{array}{l}26,27,30 \\
30\end{array}$ & $\begin{array}{l}3 \\
1\end{array}$ & $\begin{array}{r}7 \\
74\end{array}$ \\
\hline 5 & $\begin{array}{l}\begin{array}{l}34, \\
32,35 \\
32,34,35,36,37,38,40,42 \\
36,42\end{array}\end{array}$ & $\begin{array}{r}2 \\
16 \\
2\end{array}$ & $\begin{array}{r}74 \\
107 \\
119\end{array}$ \\
\hline 6 & $\begin{array}{l}47,49,50 \\
47,49,50,51,52,53,55,56,58 \\
47\end{array}$ & $\begin{array}{r}3 \\
13 \\
1\end{array}$ & $\begin{array}{r}74 \\
107 \\
119\end{array}$ \\
\hline 7 & $\begin{array}{l}62,64,65,66 \\
62,64\end{array}$ & $\begin{array}{l}8 \\
2\end{array}$ & $\begin{array}{l}107 \\
119\end{array}$ \\
\hline 8 & $\begin{array}{l}73,74,75 \\
72,73,74,75\end{array}$ & $\begin{array}{l}4 \\
6\end{array}$ & $\begin{array}{r}75 \\
106\end{array}$ \\
\hline 9 & $\begin{array}{l}78,80,82,83,84 \\
77,78,79,80,82,83,84 \\
82\end{array}$ & $\begin{array}{r}6 \\
10 \\
1\end{array}$ & $\begin{array}{r}76 \\
108 \\
119\end{array}$ \\
\hline 10 & $\begin{array}{l}90,92 \\
88,90,91 \\
90,92 \\
92\end{array}$ & $\begin{array}{r}2 \\
14 \\
2 \\
1\end{array}$ & $\begin{array}{r}112 \\
23 \\
98 \\
99\end{array}$ \\
\hline 11 & $\begin{array}{l}102,103,104,106 \mathrm{~B} \\
98,105 \\
102,104,106 \\
105 \\
105\end{array}$ & $\begin{array}{r}19 \\
2 \\
8 \\
1 \\
1\end{array}$ & $\begin{array}{r}94 \\
114 \\
23 \\
98 \\
99\end{array}$ \\
\hline 12 & $\begin{array}{l}111,112,116,118,119 \\
112,114 \\
112,114\end{array}$ & $\begin{array}{r}153 \\
2 \\
2\end{array}$ & $\begin{array}{r}96 \\
109 \\
98\end{array}$ \\
\hline 13 & $\begin{array}{l}134 \\
128,130,134 \\
128 \\
128,130 \\
125\end{array}$ & $\begin{array}{l}1 \\
4 \\
3 \\
3 \\
1\end{array}$ & $\begin{array}{r}78 \\
109 \\
23 \\
98 \\
67\end{array}$ \\
\hline
\end{tabular}




\begin{tabular}{|c|c|c|c|}
\hline 14 & $\begin{array}{l}138,144 \\
144 \\
138,144 \\
144\end{array}$ & $\begin{array}{l}6 \\
2 \\
5 \\
2\end{array}$ & $\begin{array}{r}113 \\
23 \\
98 \\
16\end{array}$ \\
\hline 15 & $\begin{array}{ll}147, & 154 \\
147 & \\
147 & \\
147 & \\
147 & \\
148 & \\
147 \\
147\end{array}$ & $\begin{array}{r}12 \\
3 \\
1 \\
3 \\
7 \\
12 \\
8 \\
4\end{array}$ & $\begin{array}{r}34 \\
111 \\
51 \\
50 \\
14 \\
3 \\
77 \\
98\end{array}$ \\
\hline 18 & $\begin{array}{l}174,176,180 \\
174,176 \\
174,176,180\end{array}$ & $\begin{array}{r}29 \\
9 \\
29\end{array}$ & $\begin{array}{l}79 \\
23 \\
86\end{array}$ \\
\hline 19 & $\begin{array}{l}185,186,189,191 \\
185,186,189,191 \\
185,186,189,191\end{array}$ & $\begin{array}{r}19 \\
4 \\
19\end{array}$ & $\begin{array}{l}80 \\
23 \\
86\end{array}$ \\
\hline 20 & 198 & 1 & 16 \\
\hline 21 & $\begin{array}{l}204,210 \\
204,210\end{array}$ & $\begin{array}{l}4 \\
4\end{array}$ & $\begin{array}{l}81 \\
86\end{array}$ \\
\hline 22 & $\begin{array}{l}217,218 \\
217,218 \\
217,218 \\
217 \\
217,218\end{array}$ & $\begin{array}{r}10 \\
4 \\
10 \\
4 \\
8\end{array}$ & $\begin{array}{r}82 \\
55 \\
115 \\
110 \\
41\end{array}$ \\
\hline 23 & $\begin{array}{l}222,229 \\
229 \\
222,229\end{array}$ & $\begin{array}{l}6 \\
1 \\
6\end{array}$ & $\begin{array}{l}85 \\
56 \\
86\end{array}$ \\
\hline 24 & $\begin{array}{ll}231 \\
231, & 232 \\
232, & 233 \\
233 & \\
231, & 232\end{array}$ & $\begin{array}{l}3 \\
9 \\
5 \\
4 \\
9\end{array}$ & $\begin{array}{l}21 \\
83 \\
56 \\
41 \\
86\end{array}$ \\
\hline 26 & $\begin{array}{l}250,254,257 \\
252,253,254,256,257,258 \\
250\end{array}$ & $\begin{array}{r}3 \\
72 \\
1\end{array}$ & $\begin{array}{l}41 \\
19 \\
16\end{array}$ \\
\hline 27 & $\begin{array}{l}259,263 \\
262 \\
262\end{array}$ & $\begin{array}{r}2 \\
11 \\
11\end{array}$ & $\begin{array}{l}41 \\
84 \\
86\end{array}$ \\
\hline
\end{tabular}


28

267

$271,272,273$

265

$1 \quad 41$

$21 \quad 86$

$1 \quad 57$

$29 \quad 278$

$12 \quad 87$

$280,281,282$

280,281

15

57

$280,281,282$

16

$31 \quad 297,298$

42

21

1

200,302

11

15

11

43

36

$327 \mathrm{~A}, 330$

330

10

24

$327 \mathrm{~A}, 330,511$

$327,330,356,357,361,363,511,530 \mathrm{~A}$

277

158

238

$332 \mathrm{~A}, 333$

6

5

38

$336,338,341,343,344,345,346$

36

13

$338,339,341,344,346,348,349$

42

$338,341,342,343,344,346,348,350$

339,345

$336,338,345,348$

341

336

39

35

52

100

13

58

34

27

92

17

39

354

356

356

10

$356,357,327,330,361,511,530 \mathrm{~A}, 363$

1

277

102

47

$360,361,362,362 \mathrm{~A}, 363,364,3365$

136

267

40

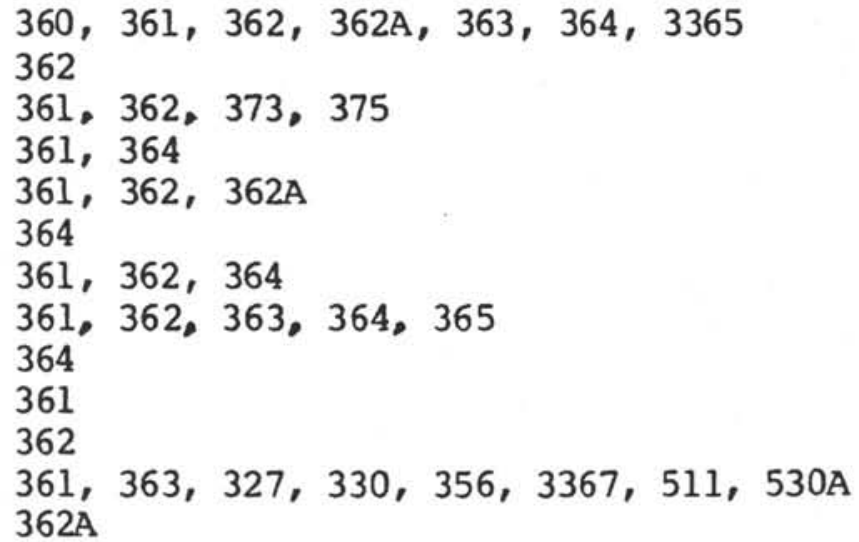

105

156

156

267

277

156 
41

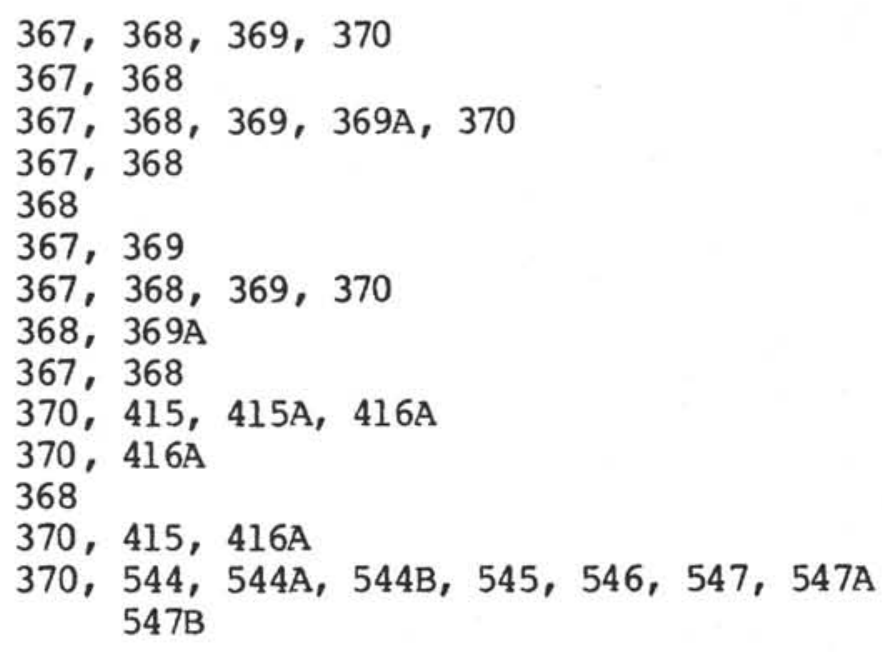

$\begin{array}{rr}6 & 64 \\ 6 & 31 \\ 28 & 10 \\ 30 & 8 \\ 11 & 36 \\ 3 & 101 \\ 6 & 60 \\ 22 & 30 \\ 7 & 29 \\ 178 & 149 \\ 24 & 150 \\ 11 & 156 \\ 10 & 159 \\ & \\ & 288\end{array}$

$42 \mathrm{~A} \quad 374,375,377,378$

32

374

372,376

376

376,378

23

3

4

4

42B 379A, 380/380A, 3381

$379 \mathrm{~A}, 379 \mathrm{~B}, 380 \mathrm{~A}, 380 \mathrm{~B}, 381$

$379,380 / 380 A, 381$

$379 \mathrm{~A}, 380 \mathrm{~A}$

$379,379 A$

$379 A, 380 A, 381$

$379 \mathrm{~A}, 379 \mathrm{~B}, 380,380 \mathrm{~A}, 381$

380

$379 A, 381$

$379,380,381$

$379 \mathrm{~A}, 379 \mathrm{~B}, 380 \mathrm{~A}$

$379 \mathrm{~A}, 379 \mathrm{~B}, 380$

300

44

38

9

23

25

25

10

6

21

63

10

27

49

4

38

67

386,387

386,387

386

$382,386,387$

386,387

24

24
4

7

16

13

61

46

120

88

48

91

11

38

118

67

53

69

$44391 \mathrm{~A}, 391 \mathrm{~B}, 391 \mathrm{C}$

391A, 391C

391,392

388A, 390, 390A, 391, 391A, 391C

63

105

50

93

391A, 391C

391A, 391C

$391 \mathrm{C}$

391A, 391B, 391C

68

388A, 391A, 391C

$\begin{array}{rr}8 & 116 \\ 8 & 28 \\ 15 & 66 \\ 37 & 39 \\ 18 & 20 \\ 15 & 32 \\ 4 & 22 \\ 12 & 12 \\ 18 & 89\end{array}$


388A, 391C

390, 391A, 391B, 391C, 392

391C, 534A

534A, 391C

(39), 392

45

$395,396,295 A$

395, 395A, 396

4

397

$\begin{array}{ll}47 \mathrm{~A} & 397 \\ & 397\end{array}$

$397,397 \mathrm{~A}, 398 \mathrm{~B}$

397 A

$397,397 A$

397, 397A, 398D

397, 397A

$397,397 A, 398 A, 398 D$

$397,397 \mathrm{~A}$

397, 397A, 398D

$397,397 A, 398 D$

45

99

147

$397 \AA$

$\begin{array}{rl}44 & 121 \\ 9 & 122 \\ 18 & 123 \\ 23 & 124 \\ 3 & 129 \\ 86 & 125 \\ 9 & 130 \\ 18 & 126 \\ 58 & 131 \\ 2 & 132 \\ & 280\end{array}$

47B 398D

398

$65 \quad 127$

398D, 397, 397A

398A, 398D, 397, 397A

398D, 397, 397A

398D, 397, 397A

398D

398D

398D

$398 D$

128

129

130

131

132

133

134

135

13

286

$48 \quad 400 \mathrm{~A}, 402 \mathrm{~A}$

$402 \mathrm{~A}$

$402 \mathrm{~A}, 404$

$402 \mathrm{~A}, 403,404$

$402 \mathrm{~A}, 403,404$

$402 A, 403,404$

$402 A$

$400 A, 402,402 A$ 399, 400, 401, 403, 404, 405,406

$401,402 A$

$399,400 A, 401,402,402 A, 403,404,405$,

$83 \quad 136$

$8 \quad 137$

$4 \quad 138$

$6 \quad 139$

$12 \quad 140$

$11 \quad 141$

$8 \quad 142$

406

$402 \mathrm{~A}$

403

404

143

144

$402 \mathrm{~A}, 416 \mathrm{~A}$

145

156

156

$\begin{array}{rr}37 & 145 \\ 8 & 156 \\ 2 & 156 \\ 2 & 156\end{array}$

$407,408,409,410,410 \mathrm{~A}, 411,412$

578

160

49

$$
-88-
$$




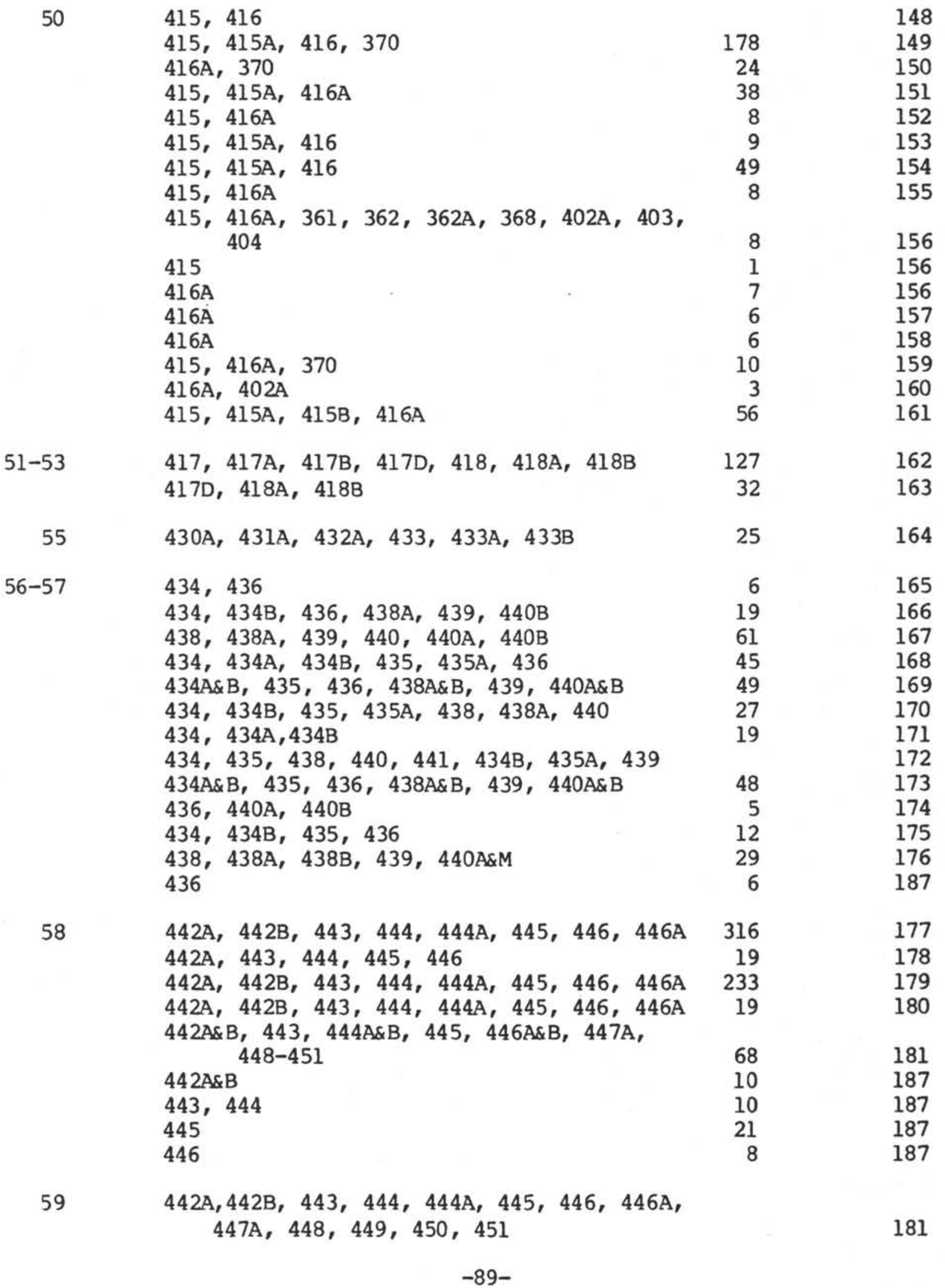


61

\section{2}

\section{2}

$462,452,453,454 \mathrm{~A}, 455,459 \mathrm{~B}, 460,436$, $442 \mathrm{~A} \& \mathrm{~B}, 443,444,445,446,447 \mathrm{~A}$, $448,449,450,451$

\section{2}

$4562,462 \mathrm{~A}$

185

6

186

62

$463,464,465,466,465 \mathrm{~A}$

$463,465 A, 466$

$463,465,465 \mathrm{~A}, 466$

463

$465 \mathrm{~A}$

466

467,468 A\&B, 469, 470, 471, 473

\section{7}

467,468 A\& B, 469, 471

196

467,471

197

467,471

198

199

200

$4667,468,469$

467,468 A\&B $, 469,470,471,472,473$

201

202

64

$474 \mathrm{~A} \& \mathrm{~B}, 475,476,477 \mathrm{~A} \& \mathrm{~B}, 478,479,480$, 481A\&B

203

$474,477,478,479,481,475,476,480,474 \mathrm{~A}$, $481 \mathrm{~A}$

$474 A \& B, 475,476,477 A \& B, 478$

204

$475,476,477 A \times B, 478$

$477 \mathrm{~B}$

$474,476,477,4789,479,481$ A\&B

206

$474 \mathrm{~A} \& \mathrm{~B}, 477,478,479,480,481 \mathrm{~A}$

207

$474 A \& B, 477,479,481 A \& B$

208

$479,481 A \& B$

474A\&B, 477, 478, 479, 481A

474A\&B, 478, 479, 481A\&B

209

$474 A \& B, 475,476,478,479,481 A \& B$

$474 \mathrm{~A} \& \mathrm{~B}, 475,476,477,478,479,480$, 481A\&B

474A\&B, 476

$\begin{array}{rr}41 & 214 \\ 5 & 216\end{array}$


$484 A \& B, 476$

477A\&B, 478, 479, 481A\&B

$474,477 A \& B, 478,479,481 A \& B$

481

479,480

479,480

474A\&B, 479

480

474A\&B， 4775A\&B，476， 477A\&B，478, 479

$482 \mathrm{~A}, \mathrm{~B}, \& \mathrm{D}, 483 \mathrm{~A}, \mathrm{~B}, \& \mathrm{C}, 484 \mathrm{~A}, 485 \mathrm{~A} \& \mathrm{~B}$

$482 A \& B, 483 B, 485 A$

66

67

68

69

71

72

73

74

75

487, 488, 489A\&B, 490, 491, 492, 493

$490,491,492$

487,491

$487,488,490$

$496,497,500$

$497,498 \mathrm{~A}$

494A, 4959, 496, 497, 499A\&B, 500

$496,499,500$

$502 A, B, \& C$

502,503

504,505

$511,327 \mathrm{~A}, 330$

511

511

$511,512,513 A \& B, 514$

511

$511,512,513$ A\&B, 514

515B, 516F

$515 A \& B, 516 A, 517$

515B, 516F

520

525A, 528A\&B

530A\&B， 532A\&B
10

$511,327,330,356,357,361,363,530 \mathrm{~A}$

$530 \mathrm{~A}$

$530 \mathrm{~A}$

532

53A\&B， 532A\&B

$530 A$
33

27

1

6

57

33

580

326

125

10

35

217

218

219

220

221

222

223

281

282

225

226

227

228

229

230

231

232

233

234

235

235

237

206

238

239

240

241

242

243

267

277

244

245

246

41

247

6

248

257

258

259

585

334

260

261

194 


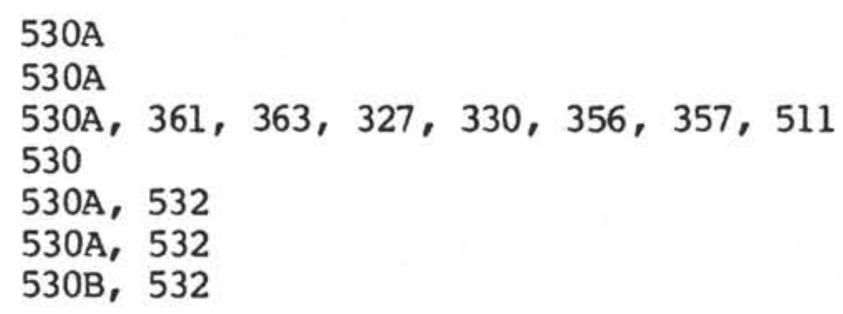

${ }_{\text {See Section } 4}$ of this Appendix for complete reference citation. 
Section 3. Index of Organic Carbon Determinations in DSDP Initial Reports, organized by leg number.

\begin{tabular}{|c|c|c|c|c|}
\hline Leg & Authors & Volume & Pages & $\begin{array}{c}\text { No. of Samples } \\
\text { Analyzed }\end{array}$ \\
\hline 1 & DSDP & 1 & $340-347$ & 127 \\
\hline 2 & DSDP & 2 & $319-321$ & 37 \\
\hline 3 & Pimm & 3 & $495-507$ & 404 \\
\hline 4 & Pimm & 4 & $307-314$ & 225 \\
\hline 5 & Vallier & 5 & $431-440$ & 286 \\
\hline 6 & Pirm & 6 & $739-752$ & 422 \\
\hline 7 & Gealy & 7 Pt 2 & $845-862$ & 513 \\
\hline 8 & DSDP & 8 & $1017-1036$ & 688 \\
\hline 9 & $\begin{array}{l}\text { Boyce, } \\
\text { Bode }\end{array}$ & 9 & $797-816$ & 645 \\
\hline 10 & Boyce & 10 & $641-642$ & 93 \\
\hline 11 & Boyce & 11 & $1059-1071$ & 466 \\
\hline 15 & Bode & 15 & $1129-1137$ & 934 \\
\hline 16 & $\begin{array}{l}\text { Bode, } \\
\text { Cronan }\end{array}$ & 16 & $521-528$ & 732 \\
\hline 17 & Bode & 17 & $927-930$ & 376 \\
\hline 18 & Bode & 18 & $1069-1076$ & 788 \\
\hline 19 & Bode & 19 & $663-665$ & 217 \\
\hline 20 & Bode & 20 & $741-742$ & 80 \\
\hline 23 & Bode & 23 & $1131-1135$ & 320 \\
\hline 24 & Bode & 24 & $1155-1156$ & 78 \\
\hline 25 & Girdley & 25 & $841^{\mathrm{a}}$ & 196 \\
\hline 27 & Bode & 27 & $499-502$ & 329 \\
\hline 30 & Cameron & 30 & $687-688$ & 124 \\
\hline 32 & Bode & 32 & $561-562$ & 123 \\
\hline 33 & Cameron & 33 & $959-963$ & 471 \\
\hline 34 & Cameron & 34 & $601-602$ & 135 \\
\hline 35 & Cameron & 35 & $755-756$ & 38 \\
\hline 36 & Cameron & 36 & $1047-1050$ & 144 \\
\hline 37 & Bode & 37 & $637-639$ & 93 \\
\hline 38 & Thampson & $\begin{array}{l}38 \\
\text { Suppl. }\end{array}$ & $433-436$ & 309 \\
\hline 39 & Scott & 39 & $501-504$ & 182 \\
\hline 41,50 & Boute feu & 50 & $555-566$ & 178 \\
\hline $42 \mathrm{~A}$ & Kidd & 42 Pt 1 & $1151-1156$ & 321 \\
\hline $42 \mathrm{~A}$ & Sigl & 42 Pt 1 & $1221-1224$ & 392 \\
\hline 43 & Cameron & 43 & $1043-1047$ & 233 \\
\hline 44 & Myers & 44 & $983-986$ & 360 \\
\hline 44,76 & Katz & 76 & $463-468$ & 53 \\
\hline 45 & Bode & 45 & $379-380$ & 45 \\
\hline 47 & $\begin{array}{l}\text { Kendrick, } \\
\text { Hood, }\end{array}$ & $47 \mathrm{Pt} 2$ & $547-551$ & 18 \\
\hline & & & $-93-$ & \\
\hline
\end{tabular}




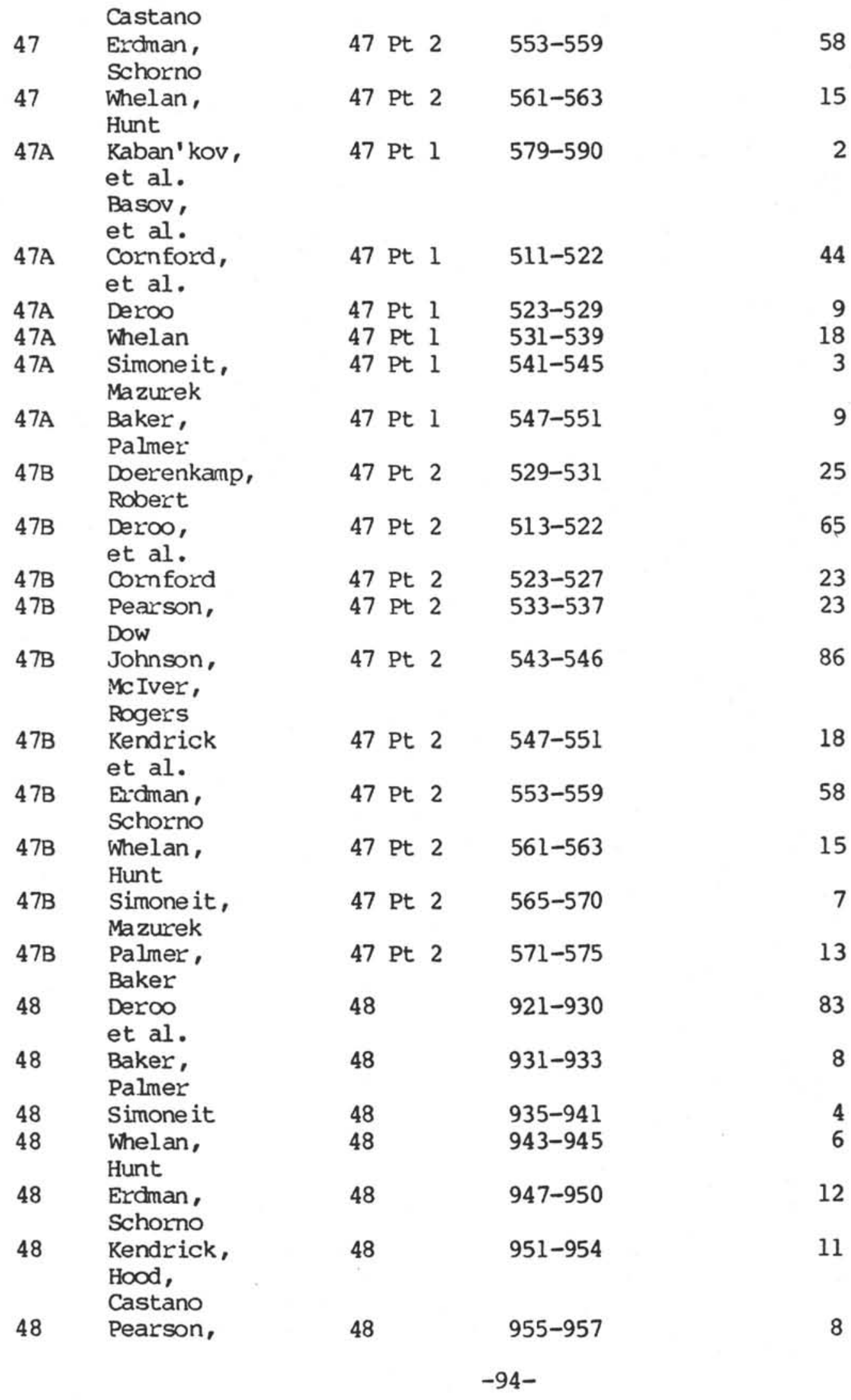




\begin{tabular}{|c|c|c|c|c|}
\hline & DOW & & & \\
\hline 48 & $\begin{array}{l}\text { Barnes } \\
\text { et al. }\end{array}$ & 48 & $965-975$ & 4 \\
\hline 48 & $\begin{array}{l}\text { Doran, } \\
\text { Johnson, } \\
\text { et al. }\end{array}$ & 48 & $977-992$ & 37 \\
\hline 49 & $\begin{array}{l}\text { White, } \\
\text { Bode }\end{array}$ & 49 & $873-882$ & 578 \\
\hline 50,41 & Boutefeu & 50 & $555-566$ & 178 \\
\hline 48 & $\begin{array}{l}\text { Boutefeu } \\
\text { et al. }\end{array}$ & 48 & $567-573$ & 24 \\
\hline 50 & $\begin{array}{l}\text { Galimov, } \\
\text { Kodina, } \\
\text { et al. }\end{array}$ & 50 & $575-600$ & 38 \\
\hline 50 & $\begin{array}{l}\text { Claypool, } \\
\text { Baysinger }\end{array}$ & 50 & $605-608$ & 8 \\
\hline 50 & Cornford & 50 & $609-514$ & 9 \\
\hline 48 & $\begin{array}{l}\text { Galimov } \\
\text { et al. }\end{array}$ & 48 & $615-622$ & 49 \\
\hline 50 & $\begin{array}{l}\text { Whelan, } \\
\text { Hunt }\end{array}$ & 50 & $623-624$ & 8 \\
\hline 50 & $\begin{array}{l}\text { Schorno, } \\
\text { Erdnan }\end{array}$ & 50 & $625-627$ & 8 \\
\hline 50 & $\begin{array}{l}\text { Deroo, } \\
\text { Herbin, } \\
\text { et al. }\end{array}$ & 50 & $629-635$ & 6 \\
\hline 50 & Simoneit & 50 & $637-641$ & 6 \\
\hline 50 & $\begin{array}{l}\text { Palmer, } \\
\text { Baker }\end{array}$ & 50 & $643-645$ & 10 \\
\hline 50 & $\begin{array}{l}\text { Brassell, } \\
\text { Conet, } \\
\text { et al. }\end{array}$ & 50 & $647-664$ & 3 \\
\hline 50 & Bode & 50 & 835 & 56 \\
\hline $51-53$ & White & $51-53$ Pt 1 & $715-718$ & 127 \\
\hline $51-53$ & $\begin{array}{l}\text { Deroo, } \\
\text { Herbin, } \\
\text { et al. }\end{array}$ & $51-53$ Pt 2 & $737-745$ & 32 \\
\hline 55 & $\begin{array}{l}\text { Jackson, } \\
\text { Koisumi, } \\
\text { et al. }\end{array}$ & 55 & $861-862$ & 25 \\
\hline 56,57 & $\begin{array}{l}\text { Rullkoetter, } \\
\text { Cornford, } \\
\text { et al. }\end{array}$ & $56-57$ Pt 2 & $1291-1304$ & 19 \\
\hline 56,57 & Sato & $56-57$ Pt 2 & $1305-1312$ & 6 \\
\hline 56,57 & $\begin{array}{l}\text { Ramankevich, } \\
\text { Nesterova, } \\
\text { et al. }\end{array}$ & $56-57$ Pt 2 & $1313-1317$ & 45 \\
\hline $\begin{array}{ll}56, & 57 \\
56, & 57\end{array}$ & $\begin{array}{l}\text { Schorno } \\
\text { Gilbert, } \\
\text { Surmerhayes, }\end{array}$ & $\begin{array}{lll}56-57 & \text { Pt } & 2 \\
56-57 & \text { Pt } & 2\end{array}$ & $\begin{array}{l}1319-1325 \\
1327-1330\end{array}$ & $\begin{array}{l}49 \\
27\end{array}$ \\
\hline
\end{tabular}




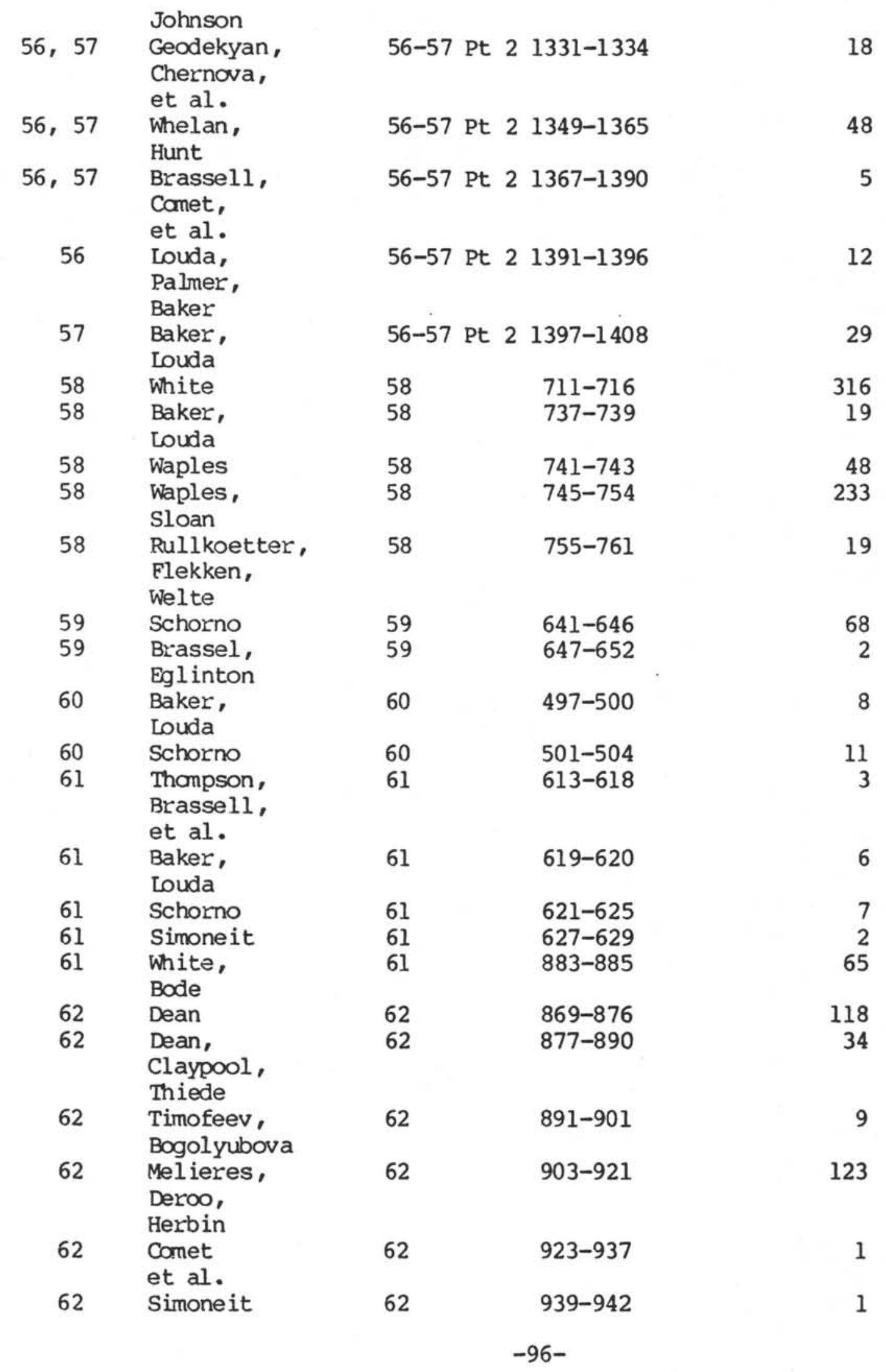




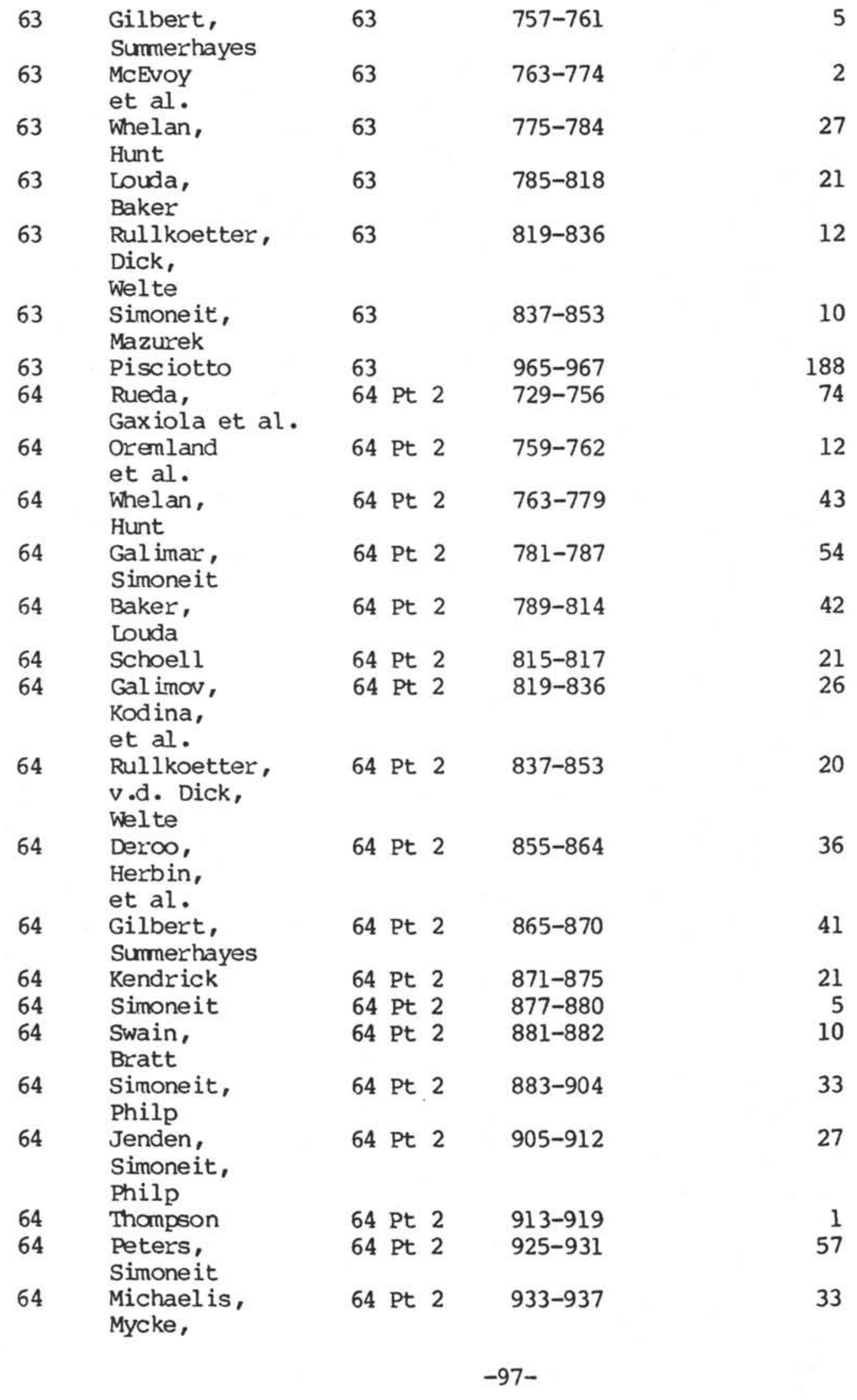




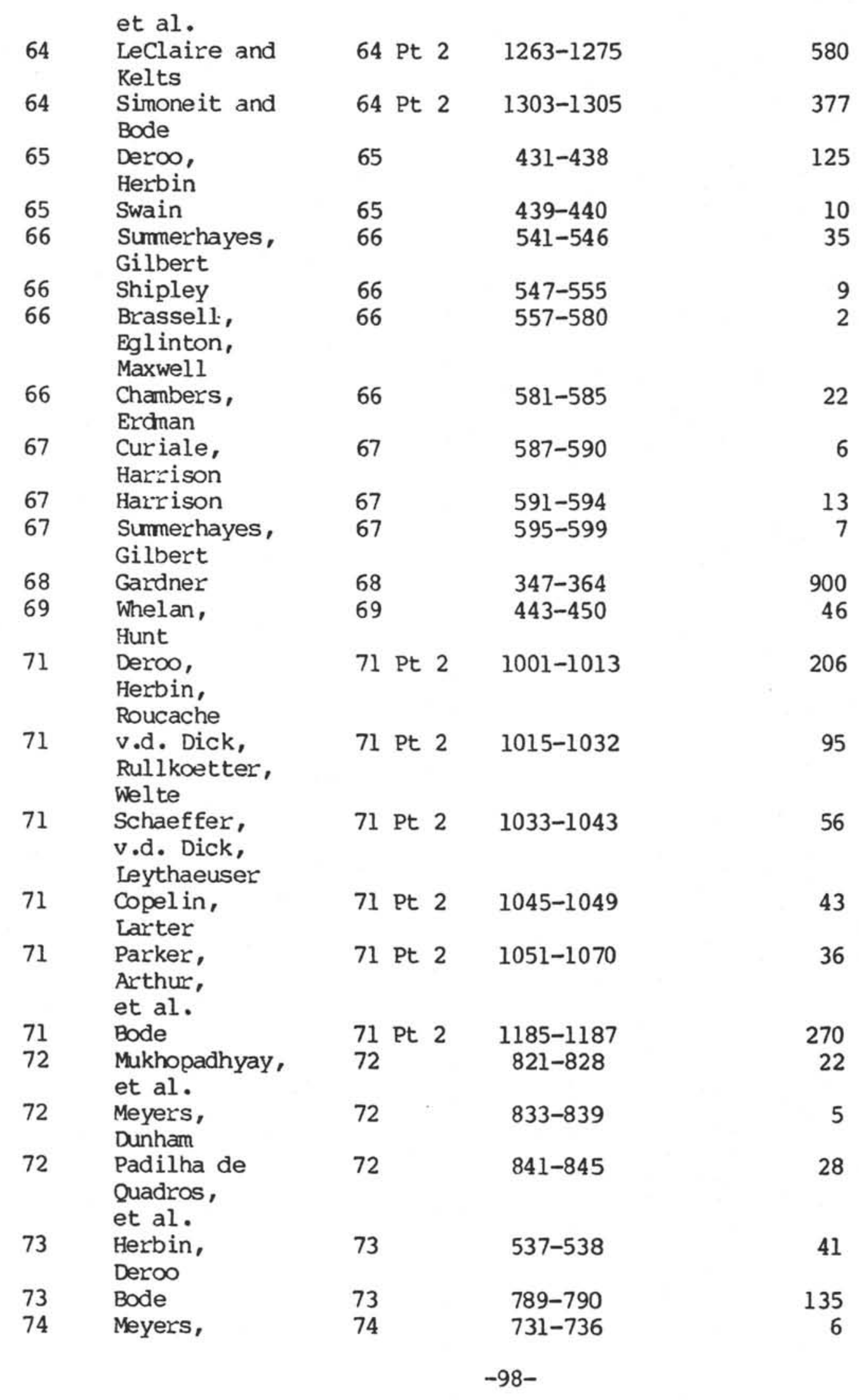


Keswani

75

75 Dean, Arthur, Stow

75 Gardner, Dean, Wilson

75 Meyers, Brassell, Huc

75 Deroo, Herbin, Huc

75 Jasper, Whelan, Hunt

75 Meyers, Trull, Kawka

75 Katz

75 Gilbert

75 Nohara, Ishizuka, Gieskes

75 Schaefer, Leythaeuser

75 Rullkoetter, et al.

75 Meyers,

Dunham

76 Brooks, Barnard, et al.

76 Claypool

76 Galinov

76 Kagami, Ishizuki and Aoki

$76 \quad$ Chamley, $\quad 76$ Debrabant et al.

76,44

76

76

$$
\text { Katz }
$$

Sumerhayes, Masran

Herbin, Deroo, Roucache

76 Robertson

76 DSDP

77 Patton,

76

76

76

77
75 Pt 2 809-817

75 Pt 2 819-844

75 Pt 2 905-921

75 Pt 2 967-981

75 Pt 2 983-999

75 Pt 2 1001-1008

75 Pt 2 1009-1018

75 Pt 2 1031-1034

75 Pt 2 1035-1049

75 Pt 2 1051-1054

75 Pt 2 1055-1067

75 Pt 2 1069-1087

75 pt 2 1089-1095

377-389

76

76

76

$391-402$

403-407

429-436

$437-451$

463-468

469-480

481-493

$763-780$

945-947

417-443
21

6

58

23

24

15

47

37

Averages of cores

50

585

334

194

13

277

47

4

2

53

22

33

11

286

40 
Choquette et al.

\begin{tabular}{|c|c|c|c|c|}
\hline 77 & Katz & 77 & $445-450$ & 85 \\
\hline 77 & $\begin{array}{l}\text { Summerhayes and } \\
\text { Masran }\end{array}$ & 77 & $451-457$ & 31 \\
\hline 77 & $\begin{array}{l}\text { Herbin, Deroo } \\
\text { and Roucache }\end{array}$ & 77 & $459-475$ & 126 \\
\hline 77 & $\begin{array}{l}\text { Palacas, King } \\
\text { et al. }\end{array}$ & 77 & $477-488$ & 6 \\
\hline 77 & $\begin{array}{l}\text { Rullkoetter } \\
\text { et al. }\end{array}$ & 77 & $489-493$ & 3 \\
\hline 77 & Bode & 77 & $739-741$ & 161 \\
\hline $78 \mathrm{~A}$ & Claypool & $78 \mathrm{~A}$ & $385-391$ & 105 \\
\hline 79 & $\begin{array}{l}\text { Mukhopadhyay } \\
\text { et al. }\end{array}$ & 79 & $493-495$ & 3 \\
\hline 79 & $\begin{array}{l}\text { Deroo, Herbin } \\
\text { and Roucache }\end{array}$ & 79 & $721-741$ & 300 \\
\hline 79 & Schaeffer et al. & 79 & $743-773$ & 54 \\
\hline 79 & $\begin{array}{l}\text { Rullkoetter } \\
\text { et al. }\end{array}$ & 79 & $775-806$ & 31 \\
\hline 79 & Simoneit et al. & 79 & $807-824$ & 15 \\
\hline 80 & $\begin{array}{l}\text { Waples and } \\
\text { Cunningham }\end{array}$ & 80 Pt 2 & $949-968$ & 500 \\
\hline 80 & $\begin{array}{l}\text { Cunningham and } \\
\text { Gilbert }\end{array}$ & 80 Pt 2 & $969-981$ & 71 \\
\hline 80 & Hartung et al. & 80 Pt 2 & 983-991 & 6 \\
\hline 80 & Waples & 80 Pt 2 & $993-997$ & 26 \\
\hline 84 & $\begin{array}{l}\text { Kvenvolden and } \\
\text { McDonald }\end{array}$ & 84 & $667-682$ & 10 \\
\hline 84 & $\begin{array}{l}\text { Kennicutt, } \\
\text { Brooks et al. }\end{array}$ & 84 & $705-717$ & 67 \\
\hline 84 & $\begin{array}{l}\text { Gilbert and } \\
\text { Cunningham }\end{array}$ & 84 & $739-742$ & 24 \\
\hline 90 & Mycke et al. & 90 & $1265-1269$ & 46 \\
\hline
\end{tabular}




\section{Section 4: References Published on Organic Geochernistry in DSDP Initial}

\section{Reports.}

(Numbers refer to references cited in Sections 1 \& 2 of this appendix)

1. Ames, R.L., and Littlejohn, R., 1975. Diagenesis of organic matter and estimated temperature history from carbonization measurements, Shikoku Basin. I.R. DSDP, 31: 621-627.

2. Anders, D.F., Claypool, G.E., Lubeck, C.M., and Patterson, J.M., 1978. Prelininary results, organic geochemical investigation of Black Sea sediments: Deep Sea Drilling Project, Leg $42 \mathrm{~B}$. I.R. DSDP, 42B: 755-763.

3. Bada, J.L., and Man, E.H., 1973. Racemization of isoleucine in cores fram Leg 15, Site 145. I.R. DSDP, 20: 947-951.

4. Bada, J.L., Man, E.H., Katz, B.J., and Hsu, K.J., 1978. Racenization of isoleucine in foraminifer tests from Leg 42A, Sites 372 and 376. I.R. DSDP, 42A: 489-491.

5. Bada, J.L., Man, E.H., and Walker, A.C., 1977. Racemization of isoleucine in Leg 37, Site 332 and 333 cores. I.R. DSDP, 37: 633-636.

6. Baker, E.W., 1969. Porphyrins. I.R. DSDP, 1: 498-499.

7. '1970. Tetrapyrrole pigments. I.R. DSDP, 4: 431-438.

8. Baker, E.W., Huang, W.Y., Rankin, J.G., Castano, J.R., Guinn, J.R., and Feux, A.N., 1977. Electron paramagnetic resonance study of themal alteration of kerogen in deep-sea sediments by basaltic sill intrusion. I.R. DSDP, 41: 839-847.

9. Baker, E.W., Palmer, S.E., and Huang, W.Y., 1978. Chlorin and porphyrin geochenistry of DSDP Leg 40 sediments. I.R. DSDP, 10: 639-647.

10. 1977. Intemediate and late diagenetic tetrapyrrole pigments, Leg 41: Cape Verde Rise and Basin. I.R. DSDP, 41: 825-837.

11. 1978. Early and intermediate diagenesis of Black Sea sediments: Sites 379, 380, 381. I.R. DSDP, 42B: 707-715.

12 . , 1978. Miocene and Cretaceous tetrapyrrole pigments from Leg 44, Site 391. I.R. DSDP, 44: 639-643.

13. Baker, E.W., Palmer, S.E., and Parrish, K.L., 1976. Tetrapyrrole pigments in DSDP Leg 38 sediments. I.R. DSDP, 38: 785-789. 
14. Baker, E.W., and Smith, G.D., 1973. Chlorophyll derivates in sediments, Site 147. I.R. DSDP, 20: 943-946.

15. 1975 . Chlorophyll derivatives in DSDP Leg 31 sediments. I.R. DSDP, 31: 629-632.

16. 1975. Chlorophyll derivatives in DSDP Leg 14, 20, 26, 27, and 29 sediments. I.R. DSDP, 31: 905-909.

17. Bogolyubova, L.J., and Timofeev, P.P., 1976. Plant organic matter in sediments from Hole 336, DSDP Leg 38. I.R. DSDP, 38: 815-821.

18. Boon, J.J., van der Meer, F.W., Schuyl, P.J.W., de Leeuw, J.W., Schenck, P.A., and Burlingame, A.L., 1978. Organic geochemical analyses of core samples from Site 362, Walvis Ridge, DSDP Leg 40. I.R. DSDP, 40:627-637.

19. Calder, J.A., Horvath, G.J., Shultz, D.J., and Newman, J.W., 1974. Geochenistry of the stable carbon isotopes in some Indian Ocean sediments. I.R. DSDP, 26: 613-617.

20. Cardoso, J.N., Wardicoper, A.M.K., Watts, C.D., Barnes, P.J., Maxwell, J.R., Eglinton, G., Mound, D.G., and Speers, G.C., 1978. Preliminary organic geochemical analyses: Site 391, Leg 44 of Deep Sea Drilling Project. I.R. DSDP, 44: 617-623.

21. Cernockm P.J., 1974. Geochernical analyses of potential petroleum source beds. I.R. DSDP, 24: 791-797.

22. Claypool, G.E., and Baysinger, J.P., 1978. Themal analysis/pyrolysis of Cretaceous saprope1s: DSDP Leg 44: Hole 391C, Blake-Bahama Basin. I.R. DSDP, 44: 635-637.

23. Claypool, G.E., Presley, B.J., and Kaplan, I.R.,, 1973. Gas analyses in sediment samples from Legs $10,11,13,14,14,18$, and 19. I.R. DSDP, 19: 879-884.

24. Comer, J.B., and Littlejohn, R., 1977. Content, composition, and thermal history of organic matter in Mesozoic sediments, Falkland Plateau. I.R. DSDP, 36: 941-944.

25. Davis, J.B., 1969. Petroleum acids. I.R. DSDP, 1: 489.

26. Davis, J.B., and Bray, E.E., 1968. Analyses of oil and cap rock from Challenger (Sigsbee) Knoll. I.R. DSDP, 1: 415-500. 
27. Deroo, G., Herbin, I.P., and Roucache', J., 1978. Organic geochenistry of some Neogene cores from Sites 374, 375, 377, and 378: Leg 42A, eastern Mediterranean Sea. I.R. DSDP, 42A: $465-472$.

28. Deroo, G., Herbin, J.P., Roucache', J.R., Tissot, B., Albrecht, P., and Dastillung, M., 1978. Organic geochenistry of same Cretaceous claystones from Site 391, Leg 44, western North Atlantic. I.R. DSDP, 44: 593-598.

29. Deroo, G., Herbin, J.P., Roucache', J., Tissot, B., Albrecht, P., and Schaeffle, J., 1977. Organic geochemistry of some Cretaceous black shales from Sites 367 and 368, Leg 41, Eastern North Atlantic. I.R. DSDP, 41: 865-873.

30. Doose, P.R., Sandstrom, M.W., Jodele, R.Z., and Kaplan, I.R., 1977. Interstitial gas analysis of sediment samples from Site 368 and Hole 369A. I.R. DSDP, 41: 861-863.

31. Dow, W.G., 1977. Contact metamorphism of kerogen in sediments from Leg 41: Cape Verde Rise and Basin. I.R. DSDP, 4l: 821-824.

32 . - 1978. Geochenical analyses of samples from Holes 391A and 391C, Leg 44: Blake-Bahama Basin. I.R. DSDP, 44: 625-633.

33. Erdman, J.G., Borst, R.L., and Scalan, R.S., 1969. Composition of gas sample 1 by components. I.R. DSDP, 1: 461-467.

34. 1969. Studies performed on samples from Challenger Knoll. I.R. DSDP, 1: 456-460.

35. Erdman, J.G., and Schorno, K.S., 1976. Geochemistry of carbon, DSDP Leg 38. I.R. DSDP, 38: 791-799.

36. 1977. Geochemistry of carbon: Deep Sea Drilling Project, Leg 41. I.R. DSDP, 41: 849-853.

37. 1978. Geochemistry of carbon: Deep sea Drilling Project, Leg 40. I.R. DSDP, 40: 651-658.

38. 1978. Geochemistry of carbon: Deep sea Drilling Project, Leg 42A. I.R. DSDP, 42B: 717-721.

39. 1978. Geochemistry of carbon: Deep sea Drilling Project, Leg 44. I.R. DSDP, 44: 605-615.

40. 1979. Geochemistry of carbon: Deep Sea Drilling Project, Leg 43. I.R. DSDP, 43: 651-655. 
41. Exdman, J.G., Schorno, K.S., and Scalan, R.S., 1974. Geochemistry of carbon: DSDP Legs 22, 24, 26, 27, and 28. I.R. DSDP, 24: 1169-1176.

42. , 1975. Geochemistry of carbon and sul fur: DSDP Leg 29. I.R. DSDP, 31: 911-916.

43. 1975. Geochemistry of carbon: DSDP Leg 31. I.R. DSDP, 31: $633-638$.

44. Evans, E.D., Bray, E.E., Bendoraitis, J.G., and Middleton, H.R., 1969. Hydrocarbon group type analysis. I.R. DSDP, 1: 492-497.

45. Evans, E.D., and Orr, W.L., 1969. Extraction of Core 5-1. I.R. DSDP, 1: 426-427.

46. Faber, E., Schnitt, M., and Stahl, W., 1978. Carbon isotope analyses of head space methane from samples of Leg $42 \mathrm{~B}$, Sites 379, 380, and 381. I.R. DSDP, 42: 667-672.

47. Foresman, J.B., 1978. Organic geochenistry: DSDP Leg 40, Continental Rise of Southwest Africa. I.R. DSDP, 40: 557-567.

48. Geodekyan, A.A., Ulmishek, G.F., Tcherova, T.G., Avilov, V.I., Bokovoy, A.P., Verkhovskaya, Z.I., and Fedorova, M.S., 1978. Bituminological studies of the samples from Site 379 and laboratory simulation of dispersed organic matter transformation. I.R. DSDP, 42B: 683-696.

49. Hahn-Weinheimer, P., Fabricices, F., Muller, J., and Sigl, W., 1978. Stable isotopes of oxygen and carbon in carbonates and organic material from pleistocene to upper Miocene sediments at Site 374 (DSDP Leg 42A). I.R. DSDP, 42A: 483-488.

50. Hare, P.E., 1973. Amino acids, amino sugars, and ammonia in sediments from the Cariaco Trench. I.R. DSDP, 20: 941-942.

51. Hoering, T.C., 1973. Characterization of the organic matter in a Site 147 core from the Cariaco Trench. I.R. DSDP, 20: 937-939.

52. Hood, A., Castano, J.R., and Kendrick, J.W., 1976. petroleum-generating potential and themal history of DSDP Leg 38 sediments. I.R. DSDP, 38: 801-803.

53. Huc, A.Y., Durand, B., and Monin, J.C., 1978. Humic compounds and kerogens in cores from Black Sea sediments, Leg 42B -- Holes 379A, B, and 380A. I.R. DSDP, 42B: 737-748. 
54. Hunt, J.M., 1973. Organic geochemical studies: Introduction and Sumary. I.R. DSDP, 20: 905.

55. 1974. Hydrocarbon and kerogen studies. I.R. DSDP, 22: 673-675.

56. 1974. Hydrocarbon and kerogen studies on Red Sea and Gul' $f$ of Aden cores. I.R. DSDP, 24: 1165-1167

57. , 1975. Hydrocarbon studies. I.R. DSDP, 31: 901-903.

58. , 1976. $\mathrm{C}_{4}-\mathrm{C}_{7}$ alkane yield. I.R. DSDP, 38: 807-808.

59. , 1978. Light hydrocarbons in Holes 361 and 364, Leg 40. I.R. DSDP, 40: 649-650.

60. Hunt, J.M., and Whelan, J.K., 1977. Light hydrocarbons at Sites 367-370, Leg 41. I.R. DSDP, 41: 859.

61. 1978. Dissolved gases in Black Sea sediments. I.R. DSDP, 42B: 661-665.

62. 1978. Light hydrocarbons, in sediments of DSDP Leg 44 holes. I.R. DSDP, 44: 651-652.

63. Kendrick, J.W., 1979. Geochemical studies of black clays from Leg 43, Deep sea Drilling Project. I.R. DSDP, 43: 633-642.

64. Kendrick, J.W., Hood, A., and Castano, J.R., 1977. petroleum-generating potential of sediments from Leg 41, Deep Sea Drilling Project. I.R. DSDP, 41: 817-819.

65. , 1978. Petroleum-generating potential of sedinents from Leg 40, Deep Sea Drilling Project. I.R. DSDP, 40: 671-676.

66. 1978. Petroleum-generating potential of sedinents fram Leg 44, Deep Sea Drilling Project. I.R. DSDP, 44: 599-603.

67. 1978. Petroleum-generating potential of sediments from the eastern Mediterranean and Black Seas. I.R. DSDP, 42B: 729-735.

68. 1979. Petroleum-generating potential of Cretaceous sediments from Leg 43, Deep Sea Drilling Project. I.R. DSDP, 43: $663-668$.

69. King, J.D., and White, D.C., 1978. Muramic acid as a measure of microbial bicmass in Black sea sediments. I.R. DSDP, 42B: 765-770. 
70. Koons, B., and Monaghan, P.H., 1969. Data and discussion of analyses by Esso Production Research Company, including $\mathrm{C}^{12} / \mathrm{C}^{13}$ ratios. I.R. DSDP, 1: $478-489$. .

71. Kvenvolden, K.A., 1976. Organic geochemistry, Leg 38: Introduction to Studies. I.R. DSDP, 38: 783-784.

72. 1977. Organic geochemistry Leg 41: Introduction and summary. I.R. DSDP, $41: 815$.

73. 1978. Introduction to organic geochemistry studies, DSDP Leg 44. I.R. DSDP, 44: 585 .

74. McIver, R.D., 1971. JOIDES cores-evidence of migration of hydrocarbons in Pleistocene sediments of the Shatsky Plateau, western Pacific Ocean. I.R. DSDP, 6: 1327-1329.

75. 1971. Organic geochemical analyses of frozen samples from DSDP Leg 8 cores. I.R. DSDP, 8: 871-872.

76. 1972. Bitumens and organic carbon in samples from DSDP Leg 9 cores. I.R. DSDP, 9: 857-858.

77. , 1973. Cyclical geochemical properties of organic matter in Cariaco Basin cores -- Leg 15, Site 147. I.R. DSDP, 20: 935-936.

78.

Geochemical significance of gas and gasoline-range hydrocarbons and organic matter in Miocene samples from Site 134 - Balearic Abyssal Plain. I.R. DSDP, 13: $813-816$.

79.

, 1973. Hydrocarbon gases from canned core samples -Sites 174A, 176, and 180. I.R. DSDP 18: 1013-1014.

80.

1973. Hydrocarbons in canned muds from Sites 185, 186, 189, 191 -- Leg 19. I.R. DSDP, 19: 875-877.

81. , 1973. Low residual gas contents of four Leg 21 canned-sediment samples. I.R. DSDP, 21: 721.

82. ' 1974. Analysis of ten Leg 22 cores for organic carbon and gasoline-range hydrocartons. I.R. DSDP, 22: 671 .

83. , 1974. Gaseous and heavy hydrocarbons in canned core samples from Leg 24, DSDP. I.R. DSDP, 24: 1157-1158.

84.

1974. Methane in canned core samples from Site 262, Timor Trough. I.R. DSDP, 27: 453-454. 
85. , 1974. Residual gas contents of organic-rich canned sediment samples from Leg 23. I.R. DSDP, 23: 971-973.

86. , 1975. Hydrocarbon gases in canned core samples from Leg 28, Sites 271, 272, and 273, Ross Sea. I.R. DSDP, 28: 815-817.

87. , 1975. Organic-matter lean sediments of Site 278, Leg 29, DSDP. I.R. DSDP, 31: 899-900.

88 . 1978. Residual hydrocarbon gases in canned cre material from Holes $379 \mathrm{~A}$ and 380A, Leg 42B. I.R. DSDP, 42B: 679-681.

89. McIver, R.D., and Rogers, M.A., 1978. Insoluble organic matter and bitumens in Leg 44 samples. I.R. DSDP, 44: 645-649.

90. Mormessin, P.R., Hood, A., Ellington, W.E., and Mannel, A.F., 1969. Analyses of organic matter in Core 5, Leg 1, Site 2. I.R. DSDP, 1: 468-477.

91. Mopper, K., Michaelis, W., Garrasi, C., and Degens, E.T., 1978. Sugars, amino acids, and hydrocarbons in Black sea sediment from DSDP Leg 42B cores. I.R. DSDP, 42B: 697-705.

92. Morris, D.A., 1976. Organic diagenesis of Miocene sedinents fram Site 341, Voring Plateau, Norway. I.R. DSDP, 38: 809-814.

93. Palmer, S.E., Huang, W.Y., and Baker, E.W., 1979. Tetrapyrrole pigments from Bermuda Rise: DSDP Leg 43. I.R. DSDP, 43: 657-661.

94. Paulus, F.J., 1972. Leg 11 measurements of physical properties in sediments of the western North Atlantic and their relationship to sediment consolidation. I.R. DSDP, 11: 667-722.

95. Raymaud, J.F., and Robert, P., 1978. Microscopical survey of organic matter fram DSDP Sites 361, 362, and 364. I.R. DSDP, 40 : $663-669$.

96. Rogers, M.A., Yąn Hinte, J.E., and Sugden, J.G. 1972. Organic carbon $C^{13}$ values from Cretaceous, Tertiary, and Quaternary marine sequences in the North Atlantic. I.R. DSDP, 12: 1115-1121.

97. Silverman, S.R., 1969. References to $\mathrm{C}^{13} / \mathrm{C}^{12}$ ratio of Challenger Knoll oil. I.R. DSDP, 1: 500 . 
98. Simoneit, B.R.T., 1973. Identification of isoprenoidal ketones in Deep Sea Drilling Project core samples and their geochemical significance. I.R. DSDP, 21: 909-923.

99.

1974. Complex triterpanoidal acids and hydrocarbons in DSDP core samples and their geochemical significance. I.R. DSDP, 24: 1159-1163.

100. , 1976. Sources of the solvent-soluble organic matter in the glacial sequence of DSDP samples from the Norwegian-Greenland Sea, Leg 38. I.R. DSDP, 38: 805-806.

101.

1977. Leg 41 sediment lipids - search for eolian organic matter in recent samples and examination of a black shale. I.R. DSDP, 41: 855-858.

102. 1977. Search for terrigenous lipids in carbonate-rich samples fron Site 39-354. I.R. DSDP, 39: 497-500.

103. , 1978. Lipid analyses of sediments from Site 364 in the Angola Basin, DSDP Leg 40. I.R. DSDP, 40: 659-662.

104. , 1978. Organic geochemistry of terrigenous muds and various shales from the Black Sea, DSDP Leg 42B. I.R. DSDP, 42B: 749-753.

105. , 1979. Organic geochemistry of the shales from the northwestern proto-Atlantic, DSDP Leg 43. I.R. DSDP, 43: 643-649.

106. Simoneit, B.R., and Burlingame, A.L., 1971. Further preliminary results on the higher molecular weight hydrocarbons and fatty acids in the DSDP cores, Legs 5-8. I.R. DSDP, 8: 873-900.

107. , 1971. Some preliminary results on the higher molecular weight hydrocarbons and fatty acids in the Deep Sea Drilling Project cores, Legs 5-7. I.R. DSDP, 7: 889-912.

108. , 1972. Further preliminary results on the higher molecular weight hydrocarbons and fatty acids in the DSDP cores, Leg 9. I.R. DSDP, 9: 859-901.

109. , 1973. Preliminary organic analyses of DSDP cores, Legs 12 and 13. I.R. DSDP, 17: 561-590.

110. , 1974. Prel iminary organic geochemical analyses of the Site 217 core samples in the Bengal Basin, DSDP Leg 22. I.R. DSDP, 22: $681-692$. 
111. Simoneit, B.R., Howells, W.G., and Burlingame, A.L., 1973. Preliminary organic geochemical analyses of the Cariaco Trench Site 147 Deep Sea Drilling Project, Leg 15. I.R. DSDP, 20: 907-933

112. Simoneit, B.R., Scott, E.S., and Burlingame, A.L., 1973. Preliminary organic analyses of the Deep sea Drilling Project cores, Leg 10. I.R. DSDP, 10: 625-636.

113. 1973. Preliminary organic analyses of DSDP cores, Leg 14, Atlantic Ocean. I.R. DSDP, 16: 575-600.

114. Simoneit, B.R., Scott, E.S., Howells, W.G., and Burlingame, A.L., 1972. Preliminary organic analyses of the Deep Sea Drilling Project cores, Leg 11. I.R. DSDP, 11: 1013-1045.

115. Snith, G.D., and Baker, E.W., 1974. Chlorophyll derivatives in DSDP Leg 22 sediments. I.R. DSDP, 22: 677-679.

116. Stuermer, D.H., and Simoneit, B.R.T., 1978. Varying sources for the lipids and hunic substances at Site 391, Blake-Bahama Basin, DSDP Leg 44. I.R. DSDP, $44: 587-591$.

117. Swain, F.M., and Bratt, J.M., 1978. Carbohydrate residues in Leg 44 core samples. I.R. DSDP, 44: 653-654.

118. Vuchev, V.T., Ivanov, C.P., St. Kabakchieva, M., Petrov, L.L., Stojanova, R.zh., Stephanov, D.D., Djakova, D.N., and Petrova, L.K., 1978. Preliminary organic geochemical studies of DSDP cores, Leg 42B, Black Sea. I.R. DSDP, 42B: 723-728.

119. Wehmiller, J.F., and Hare, P.E., 1972. Amin acid content of some samples fryom the Deep sea Drilling Program. I.R. DSDP, 9: 903-905.

120. Whelan, J.K., and Hunt, J.M., 1978. $C_{1}-C_{7}$ hydrocarbons in toles $378 \mathrm{~A}, 380 / 380 \mathrm{~A}$, and 381. I.R. DSDP, 42B: 673-677.

121. Cornford, C., 1979. Organic deposition at a continental rise: organic geochenical interpretation and synthesis at DSDP Site 397, Eastern North Atlantic. I.R. DSDP, 47 Part 1: 503-510.

122. Cornford, C., Rullkotter, J., and Welte, D., 1979. Organic chemistry of Leg 47A, Site 397, Eastern North Atlantic: organic petrography and extractable hydrocarbons. I.R. DSDP, 47 Part 1: 511-522. 
123. Deroo, G., Herbin, J.P., Roucache, J., and Tissot, B., 1979. Organic geochenistry of some organic-rich shales fram DSDP Site 397, Leg 47A, Eastern North Atlantic. I.R. DSDP, 47 Part 1: 523-529.

124. Whelan, J.K., 1979. Cl to C7 hydrocarbons from IPOD Holes 397 and 397A. I.R. DSDP, 47 Part 1: 531-539.

125. Simoneit, B.R.T., and Mazurek, M.A., 1979. Search for eolian lipids in the Pleistocene off Cape Bojador and lipid geochemistry of a Cretaceous mudstone, DSDP/IPOD Leg 47A. I.R. DSDP, 47 Part 1: 541-545.

126. Baker, E.W., and Palmer, S.E., 1979. Chlorophyll diagenesis in IPOD Leg 47A, Site 397 core samples. I.R. DSDP, 47 Part 1: $547-551$.

127. Deroo, G., Herbin, J.P., Boucache, J., and Tissot, B., 1979. Organic geochenistry of Cretaceous shales from DSDP Site 398, Leg 47B, Eastern North Atlantic. I.R. DSDP, 47 Part 2: 513-522.

128. Cornford, C., 1979. Organic petrography of Lower Cretaceous shales at DSDP Leg 47B Site 398, Vigo Seamount, Eastern North Atlantic. I.R. DSDP, 47 Part 2: 523-527.

129. Pearson, D.B., and Dow, W.G., 1979. Geochenical analysis of samples from Sites 397 and 398. I.R. DSDP, 47 part 2: 533-537.

130. Johnson, D.L., McIver, R.D., and Rogers, M.A., 1979. Insoluble organic matter bitumens in Leg 47 samples. I.R. DSDP, 47 Part 2: 543-546.

131. Kendrick, J.W., Hood, A., and Castano, J.R., 1979. Petroleum-generating potential of sediments from Leg 47, Deep Sea Drilling Project. I.R. DSDP, 47 Part 2: 547-551.

132. Erdman, J.G., and Schorno, K.S., 1979. Geochemistry of carbon: Deep Sea Drilling Project, Legs 47A and B. I.R. DSDP, 47 Part 2: 553-559.

133. Whelan, J.K., and Hunt, J.M., 1979. C2 to C7 hydrocarbons from IPOD Hole 398D. I.R. DSDP, 47 Part 2: 561-563.

134. Simoneit, B.R.T., and Mazurek, M.A., 1979. Lipid geochemistry of Cretaceous sediments fram the Vigo seamount, DSDP/IPOD Leg 47B. I.R. DSDP, 47 Part 2: 565-570.

135. Palmer, S.E., and Baker, E.W., 1979. Tetrapyrrole pigments from IPOD Leg 47B, Hole 398D. I.R. DSDP, 47 Part 2: 571-575. 
136. Deroo, G., Herbin, J.P., Roucache, J. and Tissot, B., 1979. Organic geochenistry of Cretaceous mudstones and marly limestones from DSDP Sites 400 and 402, Leg 48, Eastern North Atlantic. I.R. DSDP, 48: 921-930.

137. Baker, E.W., and Palmer, S.E., 1979. Tetrapyrrole pigments in Cretaceous sediments from the Bay of Biscay, IPOD Leg 48, Hole 402A. I.R. DSDP, 48: 931-933.

138. Simoneit, B.R.T., 1979. Lipid geochenistry of Cretaceous black shales from the Bay of Biscay, Site 402, and of Eocene mudstone from the Rockall Plateau, Site 404. I.R. DSDP, 48: 935-941.

139. Whelan, J.K., and Hunt, J.M., 1979. Sediment Cl-C7 hydrocarbons from IPOD Leg 48 - Bay of Biscay. I.R. DSDP, 48: 943-945.

140. Erdman, J.G., and Schorno, K.S., 1979. Geochemistry of carbon: Deep Sea Drilling Project Leg 48. I.R. DSDP, 48: 947-950.

141. Kendrick, J.W., Hood, A., and Castano, J.R., 1979. Petroleum-generating potential of sediments from Leg 48, Deep Sea Drilling Project. I.R. DSDP, 48: 951-954.

142. Pearson, D.B., and Dow, W.G., 1979. Geochemical analysis of samples from Leg 48, Hole 402A Bay of Biscay. I.R. DSDP, 48: 955-957.

143. Harrison, W.E., and Laporte, J.L., 1979. Shipboard organic chenistry. I.R. DSDP, 48: 959-964.

144. Barnes, P.J., Brassell, S.C., Comet, P., Eglinton, G., McEvoy, J., Maxwell, J.R., Wardroper, A.M.K., and Volkman, J.K., 1979. Preliminary lipid analyses of core sections 18,24 and 30 from Hole 402A. I.R. DSDP, 48: 965-975.

145. Doran, T., Johnson, P.G., Park, P.J.D., Speers, G.C., and Williams, J., 1979. Basic organic geochemical data of Leg 48 material. I.R. DSDP, 48: 977-992.

146. White, S.M., and Bode, G.W., 1978. Grain-size and carbon/carbonate analyses, Leg 49. I.R. DSDP, 49: 873-882.

147. Bode, G.W., 1978. Grain-size and carbon/carbonate analyses, Leg 45. I.R. DSDP, 45: 379-380.

148. Kvenvolden, K.A., 1980. Organic geochemistry, Deep Sea Drilling Project Sites 415 and 416: introduction and sumary. I.R. DSDP, 50: 553-554. 
149. Boutefeu, A., 1980. Pyrolysis study of organic matter from Deep Sea Drilling Project Site 370 (Leg 41), 415, and 416 (Leg 50). I.R. DSDP, 50: 555-566.

150. Boutefeu, A., Leplat, P., and Somers, Y., 1980. Prel iminary results of petrographic and electron-spin-resonance studies of organic matter from Deep Sea Drilling Project Sites 370 and 416. I.R. DSDP, 50: 567-573.

151. Galimov, E.M., Kodina, L.A., Shirinsky, V.G., Drozdova, T.V., Generalova, V.N., Bogachova, M.P., Chinyonov, V.A., and Vernadsky, L.A., 1980. A study of organic matter from deep oceanic bore holes, Deep Sea Drilling Project Sites 415 and 416 , in the Moroccan Basin. I.R. DSDP, 50: 575-600.

152. Claypool, G.E., and Baysinger, J.P., 1980. Analysis of organic matter in sediment cores from the Moroccan Basin, Deep Sea Drilling Project Sites 415 and 416. I.R. DSDP, 50: 605-608.

153. Cornford, C. 1980. Petrology of organic matter, Deep sea Drilling Project Site 415 and 416, Moroccan Basin, Eastern North Atlantic. I.R. DSDP, 50: 609-614.

154. Galimov, E.M., Chinyonov, V.A., and Ivanov, Y.N., 1980. Isotopic composition of methane carbon and the relative content of gaseous hydrocarbons in the deposits of the Moroccan Basin of the Atlantic Ocean (Deep Sea Drilling Project Site 415 and 416). I.R. DSDP, 50: 615-622.

155. Whelan, J.K., and Hunt, J.M., 1980. Sediment $\mathrm{Cl}$ to $\mathrm{C7}$ hydrocarbons from Deep sea Drilling Project Sites 415 and 416 (Moroccan Basin). I.R. DSDP, 50: 623-624.

156. Schorno, K.S., and Erdman, J.G., 1980. Geochemistry of carbon: Deep Sea Drilling Project Sites 415 and 416. I.R. DSDP, 50: 625-627.

157. Deroo, G., Herbin, J.P., Roucache, J., and Tissot, B., 1980. Organic geochenistry of sane lower Cretaceous shales from Deep Sea Drilling Project Site 416, Eastern North Atlantic. I.R. DSDP, 50: 629-635.

158. Simoneit, B.R.T., 1980. Organic geochemistry of Mesozoic sediments from Deep sea Drilling Project Site 330, Falkland Plateau. I.R. DSDP, 50: 637-641.

159. Palmer, S.E., and Baker, E.W., 1980. Nickel porphyrins Erom Deep Sea Drilling Project Sites 415 and 416. I.R. DSDP, 50: 643-645. 
160. Brassell, S.C., Comet, P.A., Eglinton, G., McEvoy, J., Maxwell, J.R., Quirke, J.M.E., and Volknan, J.K., 1980. Prel iminary lipid analyses of cores 14, 18, and 28 from Deep Sea Drilling Project Hole 416A. I.R. DSDP, 50: 647-664.

161. Bode, G.W., 1980. Carbon and carbonate analyses, Deep Sea Drilling Project Leg 50. I.R. DSDP, 50: 835.

162. White, S.M., 1979. Grain-size and carbon/carbonate analyses, Holes 417,418 , Legs 51, 52, 53. I.R. DSDP, 51, 52, 53, Part 1: 715-718.

163. Deroo, G., Herbin, J.P., Roucache, J., and Tissot, B., 1979. Organic geochenistry of Cretaceous sediments at DSDP Holes 417D (Leg 51), 418A (Leg 52), and 418B (Leg 53) in the Western North Atlantic. I.R. DSDP, 51, 52, 53, Part 2: 737-745.

164. Jackson, E.D., Koisumi, I., et al., 1980. Leg 55 sediment grain size and carbon/carbonate data. I.R. DSDP, 55: 861-862.

165. Thompson, P.R., and Whelan, J.K., 1980. Fecal pellets at Deep Sea Drilling Project Site 436. I.R. DSDP, 56, 57, Part 2: 921-935.

166. Rullkotter, J., Cornford, C., Flekken, P., and welte, D.H., 1980. Organic geochenistry of sediments cored during Deep Sea Drilling Project Legs 56 and 57, Japan Trench: organic petrography and extractable hydrocarbons. I.R. DSDP, 56, 57, part 2: 1291-1304.

167. Sato, S., 1980. Diagenetic alteration of organic matter in Leg 57 sediments, Deep sea Drilling Project. I.R. DSDP, 56, 57, Part 2: 1305-1312.

168. Romankevich, E.A., Nesterova, M.P., Shirshov, P.P., Shadsky, I.P., and Grinchenko, J.I., 1980. Carbon and its isotopic composition in Pacific Ocean bottom sediments, Leg 56, Deep Sea Drilling Project. I.R. DSDP, 56, 57, Part 2: 1313-1317.

169. Schorno, K.S., 1980. Geochemistry of carbon: Legs 56 and 57, Deep Sea Drilling Project. I.R. DSDP, 56, 57, Part 2: 1319-1325.

170. Gilbert, D., Summerhayes, C.P., and Johnson, D.L., 1980. Nature, origin, and petroleum source potential or organic matter from Deep Sea Drilling Project Sites 434, 435, 438, and 440 in the Japan Trench. I.R. DSDP, 56, 57, Part 2: 1327-1330. 
171. Geodekyan, A.A., Chernova, T.G., Trotsyuk, V.Y., Verkhovskaya, Z.I., and Bokovoi, A.P., 1980. Chenical and bitumenological studies from Holes 434, 434A, and 434B, Deep Sea Drilling Project. I.R. DSDP, 56, 57, Part 2: 1331-1334.

172. Whelan, J.K., and Sato, S., 1980. Cl-C5 hydrocarbons from core gas pockets, Deep sea Drilling Project Legs 56 and 57, Japan Trench Transect. I.R. DSDP, 56, 57, Part 2: 1335-1347.

173. Whelan, J.K., and Hunt, J.M., 1980. Cl-C7 volatile organic anpounds in sediments from Deep Sea Drilling Project Legs 56 and 57, Japan Trench. I.R. DSDP, 56, 57, Part 2: 1349-1365.

174. Brassell, S.C., Comet, P.A., Eglinton, G., Isaacson, P.J., McEvoy, J., Maxwell, J.R., Thanson, I.D., Tibbetts, P.J.C., and Volkman, J.K., 1980. Prel ininary lipid analyses of sections 440A-7-6, 440B-3-5, 440B-8-4, 440B-68-2 and 436-11-4: Legs 56 and 57, Deep Sea Drilling Project. I.R. DSDP, 56, 57, Part 2: $1367-1390$.

175. Louda, J.W., Palmer, S.E., and Baker, E.W., 1980. Early products of chlorophyll diagenesis in Japan Trench sediments of Deep Sea Drilling Project Sites 434, 435, and 436. I.R. DSDP, 56, 57, Part 2: 1391-1396.

176. Baker, E.W., and Louda, J.W., 1980. Products of chlorophyll diagenesis in Japan Trench sediments, Deep Sea Drilling Project Sites 438, 439, and 440. I.R. DSDP, 56, 57, Part 2: 1397-1408.

177. White, S.M., 1980. Grain-size and carbon-carbonate analyses, Leg 58. I.R. DSDP, 58: 711-716.

178. Baker, E.W. and Louda, J.W., 1980. Geochemistry of tetrapyrrole pignents in sediments of the North Philippine Sea, Deep Sea Drilling Project Leg 58. I.R. DSDP, 58: 737-739.

179. Waples, D.W., and Sloan, J.R., 1980. Carbon and nitrogen profiles in deep-sea sediments: new evidence for bacterial diagenesis at great depths of burial. I.R. DSDP, 58: 745-754.

180. Rullkotter, J., Flekken, P., and Welte, D.H., 1980. Organic petrography and extractable hydrocarbons of sediments from the Northern Philippine Sea, Deep Sea Drilling Project Leg 58. I.R. DSDP, 58: 755-761.

181. Schorno, K.S., 1980. Geochemistry of carbon: Deep Sea Drilling Project Legs 58 and 59. I.R. DSDP, 59: 641-646. 
182. Brassell, S.C., and Eglinton, G., 1980. Organic geochemical studies of two samples from Holes $447 \mathrm{~A}$ and 448 from Deep' Sea Drilling Project Leg 59. I.R. DSDP, 59: 647-652.

183. Baker, E.W., and Louda , J.W., 1981. Chlocophyll derivatives in sediments of the South Philippine Sea, Deep Sea Drilling Project Leg 60. I.R. DSDP, 60: 497-500.

184. Schorno, K.S., 1981. Geochenistry of carbon: International Phase of Ocean Drilling Project Leg 60. I.R. DSDP, 60: 501-504.

185. Thomson, I.D., Brassell, S.C., Comet, P.A., Eglinton, G., Isaacson, P.J., McEvoy, J., and Maxwell, J.R., 1981. Prel ininary lipid analyses of cores 49, 54, and 59 from Hole 462. I.R. DSDP, 61: 613-618.

186. Baker, E.W., and Louda, J.W., 1981. Geochemistry of chlorophyll derivatives: Deep Sea Drilling Project Leg 61, Site 462, Northern Nauru Basin. I.R. DSDP, 61: 619-620.

187. Schorno, K.S., 1981. Geochenistry of carbon: Deep Sea Drilling Project Leg 61, Nauru Basin, North Pacific. I.R. DSDP, 6l: $621-625$.

188. Simoneit, B.R.T., 1981. Lipid geochemistry of sediments from Site 462 in the Nauru Basin. I.R. DSDP, 61: 627-629.

139. White, S., and Bode, G.W., 1981. Appendix II. Grain-size and carbon/carbonate analyses, Leg 61. I.R. DSDP, 61: 883-885.

190. Dean, W.E., 1981. Calcium carbonate and organic carbon in samples from Deep Sea Drilling Project Sites 463, 464, 465, and 466 . I.R. DSDP, 62: 869-876.

191. Dean, W.E., Claypool, G.E., and Thiede, J., 1981. Origin of organic-carbon-rich mid-Cretaceous limestones, mid-Pacific Mountains and Southern Hess Rise. I.R. DSDP, 62: 877-890.

192. Timofeev, P.P., and Bogolyubova, L.I., 1981. Cretaceous sapropel ic deposits of Deep Sea Drilling Project Sites 463, 465 and 466. I.R. DSDP, 62: 891-901.

193. Melieres, F., Deroo, G., and Herbin, J., 1981. Organic-matter-rich and hypersiliceous Aptian sediments from western mid-Pacific mountains, Deep Sea Drilling Project Leg 62. I.R. DSDP, 62: 903-921. 
194. Comet, P.A., McEvoy, J., Brassell, S.C., Eglinton, G., Maxwell, J.R., and Thamson, I.D., 1981. Lipids of an Upper Albian limestone, Deep sea Drilling Project Site 465, Section 465A-38-3. I.R. DSDP, 62: 923-937.

195. Simoneit, B.R.T., 1981. Organic geochemistry of Albian sediment from Hess Rise, Deep Sea Drilling Project Hole 466. I.R. DSDP, 62: 939-942.

196. Gilbert, D., and Summerhayes, C.P., 1981. Distribution of organic matter in sediments along the California continental margin. I.R: DSDP, 63: 757-761.

197. McEvoy, J., Eglinton, G., and Maxwell, J.R., 1981. Prelininary lipid analyses of sedinents from sections $467-3-3$ and 467-97-2. I.R. DSDP, 63: 763-774.

198. Whelan, J.K., and Hunt, J.M., 1981. Cl-C8 hydrocarbons in IPOD Leg 63 sediments from ater California and Baja California Borderlands. I.R. DSDP, 63: 775-784.

199. Louda, J.W., and Baker, E.W., 1981. Geochemistry of tetrapyrrole, carotenoid, and perylene pignents in sediments from the San Miguel Gap (Site 467) and Baja California Borderland (Site 471), Deep Sea Drilling Project Leg 63. I.R. DSDP, 63: $785-818$.

200. Rullkotter, J., von der Dick, H., and Welte, D.H., 1981. Organic petrography and extractable hydrocarbons of sediments from the Eastern North Pacific Ocean, Deep sea Drilling Project Leg 63. I.R. DSDP, 63: 819-836.

201. Simoneit, B.R.T., and Mazurek, M.A., 1981. Organic geochemistry of sediments from the Southern California Borderland, Deep sea Drilling Project Leg 63. I.R. DSDP, 63: 837-853.

202. Pisciotto, K.A., 1981. Appendix. Grain-size and carbon/carbonate analyses, Leg 63. I.R. DSDP, 63: 965-967.

203. Simoneit, B.R.T., 1982. Organic geochemistry, Leg 64: introduction and summary. I.R. DSDP, 64 Part 2: 717-721.

204. Simoneit, B.R.T., 1982. Shipboard organic chenistry and safety monitoring, Leg 64, Gulf of California. I.R. DSDP, 64 Part 2: $723-727$. 
205. Rueda-Gaxiola, J., Morales, J., and Duenas, M.A., 1982. Optical analysis of the organic and inorganic constituents of the palynological residue in sediments from the mouth of the Gulf of California and Guaymas Basin, Deep Sea Drilling Project Leg 64: Sedimentological and diagenetic implications. I.R. DSDP, 64, Part 2: 729-756.

206. Oremland, R.S., Culbertson, C., and Simoneit, B.R.T., 1982. Methanogenic activity in sedinent from Leg 64 , Gulf of California. I.R. DSDP, 64 Part 2: 759-762.

207. Whelan, J.K., and Hunt, J.M., 1982. Cl-C8 hydrocarbons in Leg 64 sediments, Gulf of California. I.R. DSDP, 64 Part 2: 763-779.

208. Galimov, E.M., and Simoneit, B.R.T., 1982. Geochemistry of interstitial gases in sedimentary deposits of the Gulf of California, Deep Sea Drilling Project Leg 64. I.R. DSDP, 64 Part 2: 781-787.

209. Baker, E.W., and Louda, J.W., 1982. Geochemistry of tetrapyrrole, tetraterpenoid, and perylene pignents in sediments fram the Gulf of California: Deep Sea Drilling Project Leg 64, Sites 474, 477, 479, and 481, and Scripps Institution of Oceanography Guaymas Basin Survey Cruise Leg 3, Sites 10 G and 18G. I.R. DSDP, 64 Part 2: 789-814.

210. Schoell, M., 1982. Stable isotopic analyses of interstitial gases in quaternary sediments from the Gulf of California. I.R. DSDP, 64 Part 2: 815-817.

211. Galimov, E.M., Kodina, L.A., Bogacheva, M.P., and Shririnsky, V.G., 1982. Organic geochemical studies of samples from Deep sea Drilling Project Leg 64, Gulf of California: Sites 474, 477, 478,479 , and 481. I.R. DSDP, 64 Part 2: 819-836.

212. Rullkotter, J., von der Dick, H., and Welte, D.H., 1982. Organic petrography and extractable hydrocarbons of sediment from the Gulf of California, Deep Sea Drilling Project Leg 64 . I.R. DSDP, 64 Part 2: 837-853.

213. Deroo, G., Herbin, J.P., Roucache, J., Boudou, J.P., Robert, P., Jardine, S., and Marestang, P., 1982. Geochemical and optical study of organic matter in some Pleistocene and Pliocene sediment from the Gulf of California: Leg 64, Holes 474 to 481A. I.R. DSDP, 64 Part 2: 855-864.

214. Gilbert, D. and Sumerhayes, C.P., 1982. Organic facies and hydrocarton potential in the Gulf of California. I.R. DSDP, 64 Part 2: 865-870. 
215. Kendrick, J.W., 1982. Petroleum-generating potential of sediment in the Gulf of California. I.R. DSDP, 64 Part 2: 871-875.

216. Simoneit, B.R.T., 1982. Organic geochemistry of sediments from the mouth of the Gulf of California, Leg 64, Sites 474 and 476. I.R. DSDP, 64 Part 2: 877-880.

217. Swain, F.M., and Bratt, J.M., 1982. Carbohydrate residues in Leg 64 core samples. I.R. DSDP, 64 Part 2: 881-882.

218. Simoneit, B.R.T. and Philp, R.P., 1982. Organic geochemistry of lipids and kerogen and the effects of basalt intrusions on unconsolidated oceanic sediments: Sites 477, 478, and 481, Guaymas Basin, Gulf of California. I.R. DSDP, 64 Part 2: 883-904.

219. Jenden, P.D., Simoneit, B.R.T., and Philp, R.P., 1982. Hydrothermal effects on protokerogen of unconsolidated sediments from Guaymas Basin, Gulf of California: Elemental compositions, stable carbon isotope ratios, and electron spin resonance spectra. I.R. DSDP, 64 Part 2: 905-912.

220. Thamson, I.D., Brassell, S.C., Eglinton, G., and Maxwell, J.R., 1982. Preliminary lipid analysis of section 481-2-2. I.R. DSDP, 64 Part 2: 913-919.

221. Simoneit, B.R.T., 1982. Preliminary organic geochemistry of laninated versus nonlaminated sediments from Holes 479 and 480, Deep Sea Drilling Project Leg 64. I.R. DSDP, 64 Part 2: 921-924.

222. Peters, K.E., and Simoneit, B.R.T., 1982. Rock-Eval pyrolysis of Quaternary Sediments from Leg 64, Sites 479 and 480, Gulf of California. I.R. DSDP, 64 Part 2: 925-931.

223. Michaelis, W., Mycke, B., Vogt, J., Scuetze, G., and Degens, E., 1982. Organic geochemistry of interstitial waters. Sites 474 and 479, Leg 64. I.R. DSDP, 64 Part 2: 933-937.

224. Simoneit, B.R.T., and Meyers, P.A., 1982. Sources, preservation, and maturation of organic matter in Pliocene and Quaternary sediments of the Gulf of California: A synthesis of organic geochemical studies from Deep Sea Drilling Project Leg 64 . I.R. DSDP, 64 Part 2: 939-951.

225. Deroo, G., and Herbin, J.P., 1983. The nature, origin, and distribution of organic material at Deep sea Drilling Sites 482 through 485 , Leg 65 , in the Gulf of California. I.R. DSDP, 65: 431-438. 
226. Swain, F.M., and Bratt, J.M., 1983. Carbohydrate residues in core samples from the mouth of the Gulf of California. I.R. DSDP, 65: 439-440.

227. Summerhayes, C.P., and Gilbert, D., 1982. Distribution, origin, and hydrocarbon potential of organic matter in sediments from the Pacific margin of Southern Mexico. I.R. DSDP, 66: 541-546.

228. Shipley, T.H., and Didyk, B.M., 1982. Occurrence of methane hydrates offshore Southern Mexico. I.R. DSDP, 66: 547-555.

229. Brassell, S.C., Eglinton, G., and Maxwell, J.R., 1982. Preliminary lipid analyses of two Quaternary sediments from the Middle America Trench, Southern Mexico transect, Deep Sea Drilling Project Leg 66. I.R. DSDP, 66: 557-580.

230. Chambers, R.L., and Erdman, J.G., 1982. Elemental composition and petroleum-generating potential of the methylene chloride extracts from Leg 66 samples. I.R. DSDP, 66: 581-585.

231. Curiale, J.A, and Harrison, W.E., 1982. Beta-sitosterol and stigmasterol in slope sediments. I.R. DSDP, 67: 587-590.

232. Harrison, W.E., and Curiale, J.A., 1982. Gas hydrates in sediments of Holes 497 and 498A, Deep Sea Drilling Project Leg 67. I.R. DSDP, 67: 591-594.

233. Summerhayes, C.P., and Gilbert, D., 1982. Distribution, origin, and hydrocarbon potential of organic matter in sediments from the Pacific margin of Guatemala. I.R. DSDP, 67: 595-599.

234. Wolf, M., 1982. Coal petrological studies of sediments from Sites 496, 499, and 500, Deep sea Drilling Project Leg 671 Middle America Trench and slope off Guatemala. I.R. DSDP, 67: 601-602.

235. Gardner, J.V., 1982. High-resolution carbonate and organic-carbon stratigraphies for the Late Neogene and Quaternary from the western Caribbean and eastern equatorial Pacific. I.R. DSDP, 68: 347-364. (Plus microfiche in back pocket).

236. Kvenvolden, K.A., and Blunt, D.J., 1982. Amino acids in sediments from Leg 68 Site 502. I.R. DSDP, 68: 475-480.

237. Whelan, J.K., and Hunt, J.M., 1983. Organic matter in Deep Sea Drilling Project Site 504 and 505 sediments studied by a thermal analysis-gas chromatography technique. I.R. DSDP, 69: 443-450. 
238. Deroo, G., Herbin, J.P., and Poucache, J., 1983. Organic geochemistry of Upper Jurassic-Cretaceous sediments fran Site 511, Leg 71, Western South Atlantic. I.R. DSDP, 71 Part 2: 1001-1013.

239. von der Dick, H., Rullkotter, J., and Welte, D.H., 1983. Content, type, and thermal evolution of organic matter in sediments from the eastern Falkland Plateau, Deep Sea Drilling Project, Leg 71. I.R. DSDP, 71 Part 2: 1015-1032.

240. Schaefer, R.G., von der Dick, H., and Leythaeuser, D., 1983. C2-C8 hydrocarbons in sediments from Deep sea Drilling Project Leg 71, Site 511, Falkland Plateau, South Atlantic. I.R. DSDP, 71 Part 2: 1033-1043.

241. Copelin, E.C. and Larter, S.R., 1983. Chemical characterization of aromatic hydrocarbons, kerogen, and humic acids in Deep sea Drilling Project Leg 71 cores. I.R. DSDP, 71 Part 2: 1045-1049.

242. Parker, M.E., Arthur, M.A., Wise, S.W., and Wenkam, C.R., 1983. Carbonate and organic carbon cycles in Aptian-Albian black shales at Deep sea Drilling Project Site 511, Falkland Palteau. I.R. DSDP, 71 Part 2: 1051-1070.

243. Bode, G.W., 1983. Appendix II: Carbon and carbonate analyses. I.R. DSDP, 71 Part 2: 1185-1187.

244. Mukhopadhyay, P.K., Rullkotter, J., and welte, D.H., 1983. Facies and diagenesis of organic matter in sediments from the Brazil Basin and the Rio Grande Rise, Deep Sea Drilling Project Leg 72. I.R. DSDP, 72: 821-828.

245. Meyers, P.A., and Dunham, K.W., organic geochemistry of Quaternary sediments from Deep Sea Drilling Project Leg 72, South Atlantic Ocean. I.R. DSDP, 72: 833-839.

246. Padilha de Quadros, L., Soldan, A.L., and de Melo, U., 1983. Geochemical analyses of samples from Hole 515B, Vema Channel, and Hole 516F, Rio Grande Rise. I.R. DSDP, 72: 841-845.

247. Herbin, J.P., and Deroo, G., 1984. Organic geochemistry of Miocene-Pliocene laminated diatomites on the east flank of the Mid-Atlantic Ridge (Site 520, Leg 73) . I.R. DSDP, 73: 537-538.

248. Meyers, P.A., and Keswani, S.R., 1984. Organic geochemistry of Neogene sediments from the Walvis Ridge, Deep Sea Driling Project Leg 74. I.R. DSDP, 74: 731-736. 
249. Kvenvolden, Keith A., and Barnard, L.A., 1983. Gas hydrates of the Blake Outer Ridge, Site 533, Deep Sea Drilling Project Leg 76. I.R. DSDP, 76: 353-365.

250. Brooks, J.M., Barnard, L.A., Weisenberg, D.A., Kennicutt, M.C. II, and Kvenvolden, K.A., 1983. Molecular and isotopic compositions of hydrocarbons at Site 533, Deep Sea Drilling Project Leg 76. I.R. DSDP, 76: 377-389.

251. Claypool, G.E., and Threlkeld, C.N., 1983. Anoxic diagenesis and methane generation in sediments of the Blake outer Ridge, Deep Sea Drilling Project Site 533, Leg 76. I.R. DSDP, 76: $391-402$.

252. Galimov, E.M., and Kvenvolden, K.A., 1983. Concentrations and carbon isotopic compositions of $\mathrm{CH}_{4}$ anc $\mathrm{CO}_{2}$ in gas from sediments of the Blake Outer Ridge, Deep Sea Drilling Project Leg 76. I.R. DSDP, 76: 403-407.

253. Katz, B.J., 1983. Organic geochemical character of some Deep Sea Drilling Project Cores from Legs 76 and 44. I.R. DSDP, 76: 463-468.

254. Sumerhayes, C.P., and Masran, T.C., 1983. Organic facies of Cretaceous and Jurassic sediments from Deep Sea Drilling Project Site 534 in the Blake-Bahama Basin, western North Atlantic. I.R. DSDP, 76: 469-480.

255. Herbin, J.P., Deroo, G., and Roucache, J., 1983. Organic geochemistry in the Mesozoic and Cenozoic formations of Site 534, Leg 76, Blake-Bahama Basin, and comparison with Site 391, Leg 44. I.R. DSDP, 76: 481-493.

256. The Deep Sea Drilling Project, La Jolla, California, 1983. Appendix I. Carbon and Carbonate analysis, Leg 76. I.R. DSDP, 76: 945-947.

257. Meyers, P.A. 1984. Organic geochemistry of sediments from the Angola Basin and the Walvis Ridge: A synthesis of studies from Deep Sea Drilling Project Leg 75. I.R. DSDP, 75 Part 1: 459-467.

258. Stow, D.A.V., and Dean, W.E., 1984. Middle Cretaceous black shales at Site 530 in the southeastern Angola Basin. I.R. DSDP, 75 Part 2: 809-817. 
259. Dean, W.E., Arthur, M.A., and Stow, D.A.V., 1984. Origin and geochemistry of Cretaceous deep-sea black shales and multicolored claystones, with emphasis on Deep Sea Drilling Project Site 530, southern Angola Basin. I.R. DSDP, 75 Part 2: 819-844.

260. Gardner, J.V., Dean, W.E., and Wilson, C.R., 1984. Carbonate and organic-carbon cycles and the history of upwelling at Deep Sea Drilling Project Site 532, Walvis Ridge, South Atlantic Ocean. I.R. DSDP, 75 Part 2: 905-921.

261. Meyers, P.A., Brassell, S.C., and Huc, A.Y., 1984. Geochemistry of organic carbon in South Atlantic sediments from Deep Sea Drilling Project Leg 75. I.R. DSDP, 75 Part 2: 967-981.

262. Deroo, G., Herbin, J.P., and Huc, A.Y., 1984. Organic geochemistry of Cretaceous black shales from Deep sea Drilling Project Site 530, Leg 75, eastern South Atlantic. I.R. DSDP, 75 Part 2: 983-999.

263. Jasper, J.P., Whelan, J.K., and Hunt, J.M., 1984. Migration of Cl to C8 volatile organic compounds in sediments from the Deep Sea Drilling Project, Leg 75, Hole 530A. I.R. DSDP, 75 Part 2: 1001-1008.

264. Meyers, P.A., Trull, T.W., and Kawka, O.E., 1984. Organic geochemical comparison of Cretaceous green and black claystones from Hole 530A in the Angola Basin. I.R. DSDP, 75 Part 2: 1009-1018.

265. Brassell, S.C., 1984. Al iphatic hydrocarbons of a cretaceous black shale and its adjacent green claystone from the southern Angola Basin, Deep Sea Drilling Project Leg 75. I.R. DSDP, 75 Part 2: 1019-1030.

266. Katz, B.J., 1984. Organic geochemical character of selected cores, Deep Sea Drilling Project Hole 530A. I.R. DSDP, 75 Part 2: 1031-1034.

267. Gilbert, D., 1984. Organic facies variations in the Mesozoic South Atlantic. I.R. DSDP, 75 Part 2: 1035-1049.

268. Nohara, M., Ishizuka, T., and Gieskes, J.M., 1984. Organic carbon isotopic composition in Cretaceous sediments, Angola Basin, Southeastern Atlantic, Deep Sea Drilling Project Site 530. I.R. DSDP, 75 Part 2: 1051-1054.

269. Schaefer, R.G. and Leythaeuser, D., 1984. C2-C8 hydrocarbons in sediments from Deep Sea Drilling Project Leg 75, Holes 530A, Angola Basin, and 532, Walvis Ridge. I.R. DSDP, 75 Part 2: 1055-1067. 
270. Rullkotter, J., Mukhopadhyay, P.K., and Welte, D.H., 1984. Geochenistry and petrography of organic matter in sediments from Hole 530A, Angola Basin, and Hole 532, Walvis Ridge, Deep Sea Drilling Project. I.R. DSDP, 75 Part 2: 1069-1087.

271. Meyers, P.A., and Dunham, K.W., 1984. Geolipid camparison of biogenic sediments from Deep Sea Drilling Project Holes 530B, Angola Basin, and 532, Walvis Ridge. I.R. DSDP, 75 Part 2: 1089-1095.

272. Patton, J.W., Choquette, P.W., Guennel, G.K., Kaltenback, A.J., and Moore, A., 1984. Organic geochemistry and sedimentology of Lower to Mid-Cretaceous Deep Sea Carbonates, Sites 535 and 540, Leg 77. I.R. DSDP, 77: 417-443.

273. Katz, B.J., 1984. Source quality and richness of Deep Sea Drilling Project Site 535 sediments, southeastern Gulf of Mexico. I.R. DSDP, 77: 445-450.

274. Summerhayes, C.P., and Masran, T.C., 1984. Organic facies of Cretaceous sediments from Deep Sea Drilling Project Sites 535 and 540, eastern Gulf of Mexico. I.R. DSDP, 77: 451-457.

275. Herbin, J.P., Deroo, G., and Roucache, J., 1984. Organic geochemistry of Lower Cretaceous sediments from Site 535, Leg 77, Florida Straits. I.R. DSDP, 77: 459-475.

276. Palacas, J.G., King, J.D., Claypool, G.E., and Magoon, L.B., 1984. Origin of asphalt and adjacent oil stains in Lower Cretaceous fractured limestones, Deep Sea Drilling Project Leg 77 . I.R. DSDP, 77: 477-488.

277. Rullkotter, J., Mukhopadhyay, P.K., Hartung, B., and welte, D.H., 1984. Geochenistry and petrography of organic matter in Cretaceous sediments from the southeastern Gulf of Mexico, Deep Sea Drilling Project Hole 535 - Preliminary results. I.R. DSDP, 77: 489-493.

278. Bode, G.W., 1984. Appendix I. Grain-size and carbon/carbonate analyses, Leg 77. I.R. DSDP, 77: 739-741.

279. Claypool, G.E., 1984. Diagenesis of organic matter, isotopic composition of calcite veins in basement basalt and pore water in sediment - Barbados Ridge complex, Deep Sea Drilling Project Leg 78A. I.R. DSDP, 78A: 385-391.

280. Basov, V.A. et al., 1979. Lower Cretaceous lithostratigraphy of the Continental Rise off the western Sahara. I.R. DSDP, 47 Part 1: 579-590. 
281. LeClaire, J.P., and Kelts, K.R., 1982. Calcium carbonate and organic carbon stratigraphy of Late Quaternary laminated and hamogeneous diatam oozes from the Guaymas Slope, HPC Site 480, Gulf of California. I.R. DSDP, 64 Part 2: 1263-1275.

282. Simoneit, B.R.T., and Bode, G.W., 1982. Appendix II. Carbon/carbonate and nitrogen analyses, Leg 64, Gulf of California. I.R. DSDP, 64 Part 2: 1303-1305.

283. Kagami, H., Ishizuka, T., and Aoki, S., 1983. Geochenistry and mineralogy of selected carbonaceous claystones in the Lower Cretaceous from the Blake-Bahama Basin, North Atlantic. I.R. DSDP, 76: 429-436.

284. Chamley, H., Debrabant, P., Candillier, A.M., and Foulon, J., 1983. Clay mineralogical and inorganic geochenical stratigraphy of Blake-Bahama Basin since the Callovian, Site 534, Deep Sea Drilling Project Leg 76. I.R. DSDP, 76: 437-451.

285. Robertson, A.H.F., 1983. Latest Cretaceous and Eocene paleoenviroments in the Blake-Bahama Basin, western North Atlantic. I.R. DSDP, 76: 763-780.

286. Dorenkamp, A. and Robert, P., 1979. Optical study of organic matter from some samples of Cretaceous age, Leg 47B, Hole 398D. I.R. DSDP, 47 Part 2: 529-531.

287. Mukhopadhyay, P.K., spiro, B., and Rullkotter, J., 1984. An inertinite-rich coal lenticle in Triassic sediment of sample 547B-35, CC, Deep Sea Drilling Project Leg 79. I.R. DSDP, 79: $493-495$.

288. Deroo, G., Herbin, J.P., and Roucache, J., 1984. Organic geochemistry of Cenozoic and Mesozoic sediments fram Deep Sea Drilling Sites 544 to 547, Leg 79, eastern North Atlantic. I.R. DSDP, 79: 721-741.

289. Schaefer, R.G., Leythaeser, D., and Gormly, J., 1984. Generation and migration of low-molecular-weight hydrocarbons in sediments of Deep Sea Drilling Project Leg 79, Sites 544, 545, and 547, offshore Morocco. I.R. DSDP, 79: 743-773.

290. Rullkotter, J., Mukhopadhyay, P.K., Schaefer, R.G., and Welte, D.H., 1984. Geochemistry and petrography of organic matter in sediments from Deep Sea Drilling Project Sites 545 and 547, Mazagan Escarpment. I.R. DSDP, 79: 775-806. 
291. Simoneit, B.R.T., Vuchev, V.T., and Grimalt, J.D., 1984. Organic matter along the sedimentary sequences of the Moroccan continental margin, Leg 79, Sites 545 and 547 . I.R. DSDP, 79: $807-824$.

292. Waples, D.W., and Cunningham, R., 1985. Leg 80 shipboard organic geochemistry. I.R. DSDP, 80 Part 2: 949-968.

293. Cunningham, R., and Gilbert, D., 1985. Organic facies of Cenozoic and Cretaceous sediments from Deep Sea Drilling Project Sites 548 to 551, northern North Atlantic. I.R. DSDP, 80 Part 2: 969-981.

294. Hartung, B., Mukhopadhyay, P.K., Rullkotter, J., Schaefer, R.G., and Welte, D.H., 1985. Petrography and geochemistry of organic matter in Cretaceous sediments from the Goban Spur, Deep Sea Drilling Project Leg 80. I.R. DSDP, 80 Part 2: 983-991.

295. Waples, D.W., 1985. Organic and inorganic nitrogen in sediments from Leg 80, Deep Sea Drilling Project. I.R. DSDP, 80 Part 2: $993-997$.

296. Kvenvolden, K.A., and McDonald, T.J., 1985. Gas hydrates of the Middle America Trench - Deep Sea Drilling Project Leg 84. I.R. DSDP, 84: 667-682.

297. Claypool, G.E., Threlkeld, C.N., Mankiewicz, P.N., Arthur, M.A., and Anderson, T.F., 1985. Isotopic composition of interstitial fluids and origin of methane in slope sediment of the Middle America Trench, Deep Sea Drilling Project Leg 84. I.R. DSDP, 84: 683-691.

298. Galimov, E.M., and Shabaeva, I.J., 1985. Carbon isotope composition of $\mathrm{CH} 4$ and $\mathrm{CO} 2$ in sediments of the Middle America Trench. I.R. DSDP, 84: 693-694.

299. Brooks, J.M., Jeffrey, A.W.A., McDonald, T.J., Pflaum, R.C., and Kvenvolden, K.A., 1985. Geochemistry of hydrate gas and water from Site 570, Deep Sea Drilling Project Leg 84 . I.R. DSDP, 84: 699-703.

300. Kennicutt, M.C., Brooks, J.M., McDonald, T.J., and Pflaum, R.C., 1985. Nonvolatile organic matter at Sites 565-570, Deep Sea Drilling Project Leg 84. I.R. DSDP, 84: 705-717.

301. Jeffrey, A.W.A., Pflaum, R.C., McDonald, T.J., Brooks, J.M., and Kvenvolden, K.A., 1985. Isotopic analysis of core gases at Sites 565-570, Deep Sea Drilling Project Leg 84. I.R. DSDP 84: $719-726$. 
302. Simoneit, B.R.T., and Beller, H.R., 1985. Lipid geochemistry of the Cretaceous/Tertiary boundary sediments, Hole 577, Deep Sea Drilling Project Leg 86. I.R. DSDP, 86: 671-674.

303. Zolotarev, B.P., Voitov, G.I., Sarkisyan, I.S., Cherevichnaya, L.F., 1978. Distribution of gases and bitumens in basalts from Holes 395 and 396, Leg 45. I.R. DSDP, 45: 647-65l.

304. Doerenkamp, A., Robert, P., 1979. Optical study of organic matter from same samples of Cretaceous age, Leg 47B, Hole 398D. I.R. DSDP, 47B: 529-531.

305. Waples, D.W., 1980. Age of a basalt intrusion estimated by organic geochemistry. I.R. DSDP, 58: 741-743.

306. Simoneit, B.R.T., Bode, G.W., 1982.

307. Bode, G.W., 1984. Carbon and carbonate analyses. I.R. DSDP, 78: 789-790.

308. Kvenvolden, K.A., Barnard, L.A., Cameron, D.H., 1983. Pressure Core Barrel: Application to the study of gas hydrates, DSDP Site 533, Leg 76. I.R. DSDP, 76: 367-375.

309. Waples, D.W., 1985. A reappraisal of anoxia and richness of organic material, with emphasis on the Cretaceous North Atlantic. I.R. DSDP, 80/2: 999-1016.

310. Shoan, E.D., 1985. Shore-based laboratory experimental measurements on a gas-hydrate sample recovered at Site 570. I.R. DSDP 84: 695-698.

311. Gilbert, D., Cunningham, R., 1985. Organic facies variations from Leg 84, Guatemala. I.R. DSDP 84: 739-742.

312. Mycke, B., Eneis, K.C., Degens, E.T., 1985. Diagenesis of carbon compounds in Hole 593, Leg 90 (Tasman Sea) I.R. DSDP, 90: 1265-1269. 
Section 5: References to be published in Initial Reports DSDP Vols. 88 - 96

Meyers, P.A., Powaser, J.M. \& Dunham,, K.W.: Geolipids of late Cenozoic sediments from the western flank of the East Pacific Rise, DSDP Leg 92. I.R. DSDP, 92.

Arthur, M.A., Hagety, , S., Dean, W.E., Claypool, G., Davies, T.A., \& McManaman, D.: A geochemical note: comparison of techniques for obtaining $\mathrm{CaCO}_{3}$, organic carbon and total nitrogen in limestones and shales. I.R. DSDP Leg 93.

Dean, W.E. \& Arthur, M.A.: Inorganic and organic geochemistry of rocks and sediments recovered from the lower continental rise, North American Basin, Site 603, DSDP Leg 93. I.R. DSDP Leg 93.

Dunhan, K.W., Meyers, P.A. \& Dunham, P.L.: Organic geochemical comparison of Cretaceous black shales and adjacent strata from DSDP Site 603, outer Hatteras Rise. I.R. DSDP Leg 93.

Eneis, K.-C., Mycke, B.,Richnow, H.-H., Spitzy, A., \& Degens, E.T.: Organic carbon and nitrogen, sediment composition, and clay mineralogy of DSDP Site 603, western Atlantic Ocean. I.R. DSDP Leg 93.

Herbin, J.P., Masure, E. \& Roucache, J.: Organic Geochemistry and Dinoflagellate cysts of Cretaceous formations from Site 603, Leg 93, lower continental rise of Cape Hatteras. Comparison of the Cenomanian/Turonian Boundary Event (CTBE) with Site 105, Leg 11. I.R. DSDP Leg 93.

Joyce, R.M. \& Van Vleet, E.S.: Geochemical studies on organic-rich sediments from DSDP Site 603B. I.R. DSDP Leg 93.

Katz, B.J.: Organic geochemical character and hydrocarbon source potential of selected black shales, DSDP Hole 603B. I.R. DSDP Leg 93.

Meyers, P.A.: Organic carbon in sediments and rocks from Site 603, 604 , and 605, western margin of the North Atlantic. I.R. DSDP Leg 93.

Meyers, P.A.: Organic geochemical synthesis Site 605. I.R. DSDP Leg 93.

Meyers, P.A.: Organic carbon and calcium carbonate analyses, DSDP Leg 93, North American continental rise and slope. I.R. DSDP Leg 93. 
Schaefer, R.G. \& Leythaeuser, D.: Low molecular weight hydrocarbons in sediments of DSDP Leg 93, Hole 603B, off North Carolina. I.R. DSDP Leg 93.

Simoneit, B.R.T. \& Beller, H.R.: Lipid geochemistry of Cr taceous/Tertiary boundary sediments, Hole 605, DSDP Leg 93 and Stevns Klint, Denmark. I.R. DSDP Leg 93.

Whelan, J.K. \& Burton, $C_{0}: C_{1}$ to $C_{8}$ hydrocarbons in Site 603 sediments. I.R. DSDP Leg 93.

Tarafa, M.E., Whelan, J.K., Oremland, R.S., \& Smith, R.L.: Methanogenesis at Site 612, 613, 618, and 619. I.R. DSDP Leg 95.

Whiticar, M.J. \& Faber, E.: Carbon and isotopes on gas samples from Leg 95, Sites 603D and 613. I.R. DSDP Leg 95.

Burke, R.A., Sackett, W.M. \& Brooks, J.M.: Hydrogen and carbon isotope compositions of methane from DSDP Site 618, Orca Basin. I.R. DSDP Leg 96.

Ishizuka, T., Ittekkot, V., Degens, E.T. \& Kawahata, H.: Preliminary data on dissolved organic carbon and sugar in interstitial water from the Mississippi Fan and Orca and Pigmy Basins, DSDP Leg 96. I.R. DSDP Leg 96.

Kennicutt, M.C., De Freitas, D.A., Joyce, J.E. \& Brooks, J.M.: Nonvolatile organic matter in sediments from Sites 614 to 623, DSDP Leg 96. I.R. DSDP Leg 96.

Pflaum, R.C., Brooks, J.M., Cox, H.B., Kennicutt, M.C., \& Sheu, D.-D.: Molecular and isotopic analysis of core gases and gas hydrates, DSDP Leg 96. I.R. DSDP Leg 96.

Requejo, A.G., Whelan, J.K. \& Boehn, P.D.: Hydrocarbon geochemistry and biological markers in Orca and Pigmy Basin sediments (Sites 618 and 619). I.R. DSDP Leg 96.

Whelan, J.K.: Geochemistry summary - Leg 96 - the Mississippi Fan. I.R. DSDP Leg 96.

Whelan, J.K., Oremland, R., Tarafa, M., Smith, R., Howarth, R. \& , Lee, C.: Evidence for sulfate reducing and methane producing microorganisms in sediments from Sites 618, 619, and 622 . I.R. DSDP Leg 96. 


\section{Section 6: General Library References}

1) Barker, Colin. Organic Geochenistry in Petroleum Exploration.

2) Bouma, Arnold H., George T. Moore, and James M. Coleman, Eds.. Framework, Facies, and Oil-Trapping Characteristics of the Upper Continental Margin.

3) Chapman, R.E. Petroleum Geology •

4) Cormission of the European Communities, Teminology Bureau, Luxembourg. Onshore/Offshore Oil and Gas Multilingual Glossary.

5) Demaison, Gerard and Roelef J. Murris. Petroleum Geochemistry and Basin Evaluation.

6) Dickinson, William R. and Hunter Yarborough. Plate Tectonics and Hydrocarbon Accumulation.

7) Durand, Bernard, Ed. Kerogen: Insoluble Organic Matter from Sedimentary rocks.

8) Duursma, E.K. and Dawson, R. Eds. Marine Organic Geochemistry.

9) Eglington, G. and M. Murphy, Eds. Organic Geochenistry: Methods and Results.

10) Hobson, G.D. Developnents in Petroleum Geology, 2 Vols.

11) Hunt, John Meachan. Petroleum Geochenistry and Geology •

12) Ioffe, Boris V. and Vitenberg, A.G., trans. by Ilya A. Mamantov. Head-Space Analysis and Related Methods in Gas Chromatography.

13) Kaplan, Isaac R., Ed. and U.S. Office of Naval Res, Ocean Sci and Tech Div. Natural Gases in Marine Sediments.

14) Krauskopf, Konrad Bates. Introduction to Geochemistry.

15) Kvenvolden, Keith A., Ed. Geochenistry of Organic Mblecules.

16) Makagon, I.U.F., trans by W.J. Cielslewicz. Hydrates of Natural Gas.

17) Schlanger, Seymour Oscar and Maria Bianca Cita. Nature and Origin of Cretaceous Carbon-Rich Facies.

18) Schlee, John S., Ed., Interregional Unconformities and Hydrocarbon Accumulation. 
19) Scholle, Peter A. Deposition, Diagenesis, and Hydrocarbon Potential of "Deeper-Water" Limestones.

20) Siegel, Fredric R. Applied Geochemistry.

21) Tissot, B. and D. Welte. Petroleum Formation and occurence.

22) Waples, Douglas. Organic Geochemistry for Exploration Geologists.

23) Wedepohl, Karl, Ed. Handbook of Geochemistry, Vol 1 and Vol 2 Pts 1-5.

24) Zlatkis, Albert and Victor Pretorius, Eds. Preparative Gas Chromatography. 


\section{METHANE AND OTHER HYDROCARBON GASES IN MARINE SEDIMENT ${ }^{1}$}

George E. Claypool

US Geological Survey, Denver, Colorado 80225

Keith A. Kvenvolden

US Geological Survey, Menlo Park, California 94025

\section{INTRODUCTION}

Hydrocarbon gases are common in marine sediment accumulating in present-day oceans. Such gases originate from the decomposition of organic matter by biochemical and chemical processes. We consider seven hydrocarbon gases that occur in marine sediment (Table 1). In addition, inorganic gases such as nitrogen $\left(\mathrm{N}_{2}\right)$, argon $(\mathrm{Ar})$, carbon dioxide $\left(\mathrm{CO}_{2}\right)$, and helium (He) are present, but usually as minor or trace components in natural gas. These will not be discussed here.

Methane $\left(\mathrm{C}_{1}\right)$ is almost always the dominant component of the natural gas mixtures. Usually accompanying $C_{1}$ are other hydrocarbon gases, including ethane $\left(\mathrm{C}_{2}\right)$, propane $\left(\mathrm{C}_{3}\right)$, isobutane $\left(\mathrm{i}-\mathrm{C}_{4}\right)$, and normal butane ( $n$ $\mathrm{C}_{4}$ ), that are present in variable amounts from traces to $30-40$ percent collectively. Marine sediments also contain volatile hydrocarbons of higher molecular weight, e.g. $C_{5}$ through at least $C_{7}$ (Hunt 1975), but our discussion is confined to permanent gas hydrocarbons $C_{1}$ through $C_{4}$. In addition to gaseous alkanes, the alkenes, ethene $\left(C_{2}\right)$ and propene $\left(C_{3}\right)$, are found also, but mainly in sediment near the seafloor and in the overlying water column.

There are three main stages of natural gas formation during the burial history of sediment. The earliest stage is biological $C_{1}$ formation, which

\footnotetext{
'The US Government has the right to retain a nonexclusive royalty-free license in and to any copyright covering this paper.
}

Reproduced, with permission, from the Annual Review of Earth and Planetary Sciences, Vol 11, (C) 1983 by Annual Reviews Inc. 
Table 1 Hydrocarbon gases in marine sediment

\begin{tabular}{lccc}
\hline Name & Symbol & Molecular formula & Molecular weight \\
\hline Methane & $\mathrm{C}_{1}$ & $\mathrm{CH}_{4}$ & 16 \\
Ethene & $\mathrm{C}_{2}-$ & $\mathrm{C}_{2} \mathrm{H}_{4}$ & 28 \\
Ethane & $\mathrm{C}_{2}$ & $\mathrm{C}_{2} \mathrm{H}_{6}$ & 30 \\
Propene & $\mathrm{C}_{3}-$ & $\mathrm{C}_{3} \mathrm{H}_{6}$ & 42 \\
Propane & $\mathrm{C}_{3}$ & $\mathrm{C}_{3} \mathrm{H}_{6}$ & 44 \\
Isobutane & $\mathrm{i}-\mathrm{C}_{4}$ & $\mathrm{C}_{4} \mathrm{H}_{10}$ & 58 \\
n-Butane & $n-\mathrm{C}_{4}$ & $\mathrm{C}_{4} \mathrm{H}_{10}$ & 58 \\
\hline
\end{tabular}

occurs at low temperatures $\left(<50^{\circ} \mathrm{C}\right)$ under certain environmental conditions. The next stage is early thermogenic (nonbiological) gas formation, in which the whole series of gaseous and liquid hydrocarbons are formed at rates that become geologically significant when burial temperatures are in the range of $80-120^{\circ} \mathrm{C}$. Late thermogenic $C_{1}$-rich gas is produced during the last stage of gas formation, at temperatures higher than about $150^{\circ} \mathrm{C}$ at which previously formed heavier hydrocarbons are converted to $C_{1}$. Natural gas formed during each of these stages has a characteristic chemical and isotopic composition.

Cold bottom water $\left(\simeq 2^{\circ} \mathrm{C}\right)$ and thin sediment cover $(<1 \mathrm{~km})$ over most of the deep ocean basins prevent attainment in the sediment of the temperatures required for significant nonbiological gas formation, except in unusual circumstances. Only at continental margins or at active ocean ridges are sediment temperatures achieved that permit significant nonbiological gas generation from high-temperature $\left(80-150^{\circ} \mathrm{C}\right)$ decomposition of organic matter. As a consequence, the low-temperature biological decomposition of organic matter is the most important $\mathrm{C}_{1}$-generating process operating in marine sediments accumulating in present-day oceans.

$C_{1}$ generation in nonmarine environments, e.g. "marsh gas," is an obvious consequence of organic decay under anaerobic conditions. However, prior to the advent of deep coring of the seafloor by the Deep Sea Drilling Project (DSDP), the extent of $C_{1}$ occurrence in the marine environment was not widely appreciated or understood (Atkinson \& Richards 1967). Gassy marine sediments occasionally have been reported in coring operations in which penetration was limited to the upper $5 \mathrm{~m}$ of surface sediment (Revelle 1950, Emery \& Hoggan 1958, Reeburgh 1969. 1976, 1980, Nissenbaum et al 1972, Rashid et al 1975, Martens \& Berner 1977), but gassy sediments are more commonly found in DSDP rotary coring, at depths previously unattainable by conventional gravity or piston coring. 


\section{$C_{1}$ GENERATION AND CONSUMPTION PROCESSES}

Sedimentary $C_{1}$ is formed by both biological and nonbiological decomposition of buried organic matter. Anaerobic microorganisms produce relatively pure $C_{1}$ enriched in the light isotope ${ }^{12} \mathrm{C}$. $C_{1}$, as well as other alkane hydrocarbons, is produced by nonbiological, spontaneous decomposition of organic matter at rates that increase in an exponential fashion with increasing temperatures. At average Earth-surface temperatures $\left(10-25^{\circ} \mathrm{C}\right)$, the rate of nonbiological hydrocarbon formation is extremely slow, and these hydrocarbons probably do not make a volumetrically significant contribution to economic gas occurrence, even when the process has continued over geological time periods. Only when organic matter is heated to temperatures of about $100^{\circ} \mathrm{C}$ (Frank et al 1974) does nonbiological gas formation occur at rates that are significant on the time-scale of the development period of sedimentary basins $\left(10^{8} \mathrm{yr}\right)$.

Hydrocarbons $\left(C_{1}\right.$ in particular $)$ are subject to rapid biological oxidation in aqueous systems that contain dissolved $\mathrm{O}_{2}$ (Rudd et al 1974, Patt et al 1974, Rudd \& Hamilton 1975, 1978, Jannasch 1975, Rudd 1980). In addition, there is evidence that $C_{1}$ can be anaerobically oxidized in conjunction with active sulfate reduction (Reeburgh 1976, 1980, Reeburgh \& Heggie 1977, Barnes \& Goldberg 1976, Kosiur \& Warford 1979). The processes of aerobic oxidation of hydrocarbons are well understood (McKenna \& Kallio 1965), but the mechanisms for anaerobic degradation are still a matter of debate. In general, $C_{1}$ content in aerobic and sulfatecontaining sediment is low $\left(<10^{-4}\right.$ standard volumes of gas per volume of sediment, $v / v)$ and is most properly viewed as a result of the balance between $C_{1}$ production or influx, and $C_{1}$ consumption. In anoxic, sulfatefree, or low-sulfate sediment beneath a water column of sufficient depth to inhibit bubble formation, $C_{1}$ content can be high $(0.05-2 \mathrm{v} / \mathrm{v})$ and $C_{1}$ loss is by upward diffusion.

\section{Biological Processes}

The breakdown of organic matter in anoxic environments involves a complex sequence of processes symbolized in Figure 1, which is modified and expanded after Mah et al (1977). Dead organic tissue is dissaggregated and hydrolytically decomposed to yield the constituent biopolymerscellulose, alginate, proteins, and lipids. The more labile of these biopolymers are hydrolyzed to yield the biomonomers (sugars, uronic acids, amino acids, fatty acids), which in turn are decomposed by fermentation and anaerobic oxidation reactions to give 2-, 3-, and 4-carbon organic 
compounds (acids, alcohols, aldehydes, etc). These short-chain organic compounds are further oxidized to $\mathrm{CO}_{2}$, with consequent production of electrons or hydrogen. Continued metabolic activity depends on the removal of electrons by the biologically mediated reduction of certain inorganic compounds known as electron acceptors. A variety of multivalent elements (including $\mathrm{O}, \mathrm{Fe}, \mathrm{Mn}, \mathrm{N}, \mathrm{S}, \mathrm{C}$ ) can act as electron acceptors. In the interstitial waters of anoxic marine sediments, dissolved $\mathrm{SO}_{4}^{2-}$ and $\mathrm{CO}_{2}$ are the most important electron acceptor compounds.

$C_{1}$ in low-temperature marine environments probably is produced from a limited range of substrates: $\mathrm{H}_{2}+\mathrm{CO}_{2}$, acetate, and formate (Mah et al 1977). Other compounds (methanol, trimethylamine, methionine, methyl mercaptan, and dimethyl sulfide) apparently can provide alternative carbon substrates for methanogenesis under unusual environmental conditions (Zinder \& Brock 1978, Oremland et al 1982a). Of the more common substrates, formate is believed to be more readily converted to $\mathrm{H}_{2}+\mathrm{CO}_{2}$ than fermented to $C_{1}$ (Hungate et al 1970). With respect to the relative importance of acetate vs $\mathrm{H}_{2}+\mathrm{CO}_{2}$ as substrates for methanogenesis.

ORGANIC TISSUES

(phytoplankton, bacterial bodies, plant debris)

$\mid$ disaggregation, hydrolysis

BIOPOLYMERS

(carbohydrates, proteins, lipids)

$\downarrow$ hydrolysis

BIOMONOMERS

(sugars, amino acids, fatty acids)

$\downarrow$ fermentation, anaerobic oxidation

2,3,4-CARBON, ACIDS, ALCOHOLS, ALDEHYDES

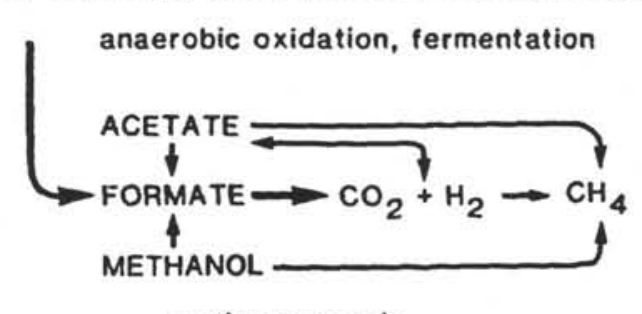

methanogenesis

Fiyure I Sequence of organic matter degradation reactions in marine sediments. 
environmental conditions also are important (Mah et al 1977, Mountfort \& Asher 1978). Evidence for the importance of acetate fermentation in shallow-water, coastal lagoons is conflicting (Sørensen et al 1981, Sansone \& Martens 1981). In deeper-water marine sediments, the evidence favors $\mathrm{CO}_{2}$ reduction as the dominant methanogenic process; acetate fermentation is an energetically less favorable process (Zeikus 1977). Radiolabeling experiments have shown that acetate is anaerobically oxidized to $\mathrm{CO}_{2}$ prior to $\mathrm{C}_{1}$-generation in Santa Barbara Basin sediments (Warford et al 1979), and that 55-9.9\% of $C_{1}$ in Baltic Sea sediments was formed via $\mathrm{CO}_{2}$ reduction (Lein et al 1981).

Sulfate-reducing bacteria are believed to compete so favorably with $\mathrm{CO}_{2}$-reducing microorganisms for available electron donors or hydrogen that $\mathrm{C}_{1}$ production can be inhibited in the presence of dissolved $\mathrm{SO}_{4}^{2-}$ (Claypool \& Kaplan 1974, Martens \& Berner 1974, Winfrey \& Zeikus 1977. Abram \& Nedwell 1978, Sansone \& Martens 1981). Apparently, biological $\mathrm{C}_{1}$ production does not occur at optimum rates in most marine sediments until more than $80 \%$ of the dissolved $\mathrm{SO}_{4}^{2-}$ is depleted (Nikaido 1977). The depth of $\mathrm{SO}_{4}^{2-}$ depletion depends on the relative rates of biological processes and replenishment of $\mathrm{SO}_{4}^{2-}$ from overlying sea water, and varies from as little as a few centimeters to as much as $200 \mathrm{~m}$. In marine environments, sediment immediately beneath the effective depth of $\mathrm{SO}_{4}^{2-}$ depletion invariably contains abundant $C_{1}$, and displays other geochemical changes indicating that rapid $\mathrm{C}_{\mathbf{1}}$ generation is taking place (Claypool \& Kaplan 1974). Thus, a separation exists between sediment zones where $C_{1}$ production and $\mathrm{SO}_{4}^{2-}$ reduction are the dominant terminal processes. The two processes are not, however, mutually exclusive in the strictest sense (Oremland \& Taylor 1978, Mountfort et al 1980, Oremland et al 1982b).

The apparent inhibition of methanogenesis by $\mathrm{SO}_{4}^{2-}$ is usually rationalized in terms of a competitive advantage conferred by greater relative freeenergy yield for $\mathrm{SO}_{4}^{2-}$ reduction (Claypool \& Kaplan 1974. Berner 1980). However, a more direct, mechanistic explanation involves the observed, more favorable kinetic parameters for $\mathrm{H}_{2}$ utilization possessed by $\mathrm{SO}_{4}^{2-}$ reducing bacteria compared with methanogens (Kristjansson et al 1982). In this manner, $\mathrm{SO}_{4}^{2-}$ concentration determines the dominant anaerobic respiration process, whereas the actual rates of either process are affected by other factors controlling substrate availability (Winfrey et al 1981).

\section{Concentration And Isotopic Depth Profiles}

One of the main lines of evidence for sequential $\mathrm{SO}_{4}^{2}$-reducing and $\mathrm{C}_{1}$ producing anoxic diagenetic processes related to the most energetically efficient a vailable electron acceptor comes from studies of interstitial waters from marine sediments (Berner 1980). In particular, the depth distribution 
of dissolved sulfur and carbon species and their stable isotope ratios clearly indicate distinct zones of diagenesis. An idealized depth plot of the concentration and $\delta$-values ${ }^{2}$ for some of the dissolved carbon and sulfur species in the porewater of typical anoxic marine sediments is shown as Figure 2. The depth scale of Figure 2 is arbitrary in the sense that the units of depth can vary from $10^{-1}$ to $10^{2} \mathrm{~m}$, depending on several factors, the most important of which is the rate of sediment accumulation. Figure 2 is a generalized composite of porewater data from several deep-water depositional environments, but draws most heavily on data from the Astoria Fan (Claypool 1974) and the Blake Outer Ridge (Claypool \& Threlkeld 1983).

The depth profile of dissolved sulfate shows a regular decrease from seawater concentrations near the seafloor to zero at an arbitrary depth of 2 units. Over this same depth interval, the $\delta^{34} \mathrm{~S}$ of residual sulfate increases from $+20 \%$ to about $+50 \%$. Dissolved $\mathrm{CO}_{2}$ concentration increases as sulfate concentration decreases, and may reach values that are twice the original sulfate concentration in seawater ( 56 millimolar). Because the increased $\Sigma \mathrm{CO}_{2}$ is derived from oxidation of organic matter, the $\delta^{13} \mathrm{C}$ of $\Sigma \mathrm{CO}_{2}$ decreases rapidly with sediment depth from seawater values of $0 \%$ 。 near the seafloor to the $\delta^{13} \mathrm{C}$ range of organic carbon $(-25 \pm 2 \%)$ and remains at this value down to a depth of about 2 units.

At depths greater than 2 units in Figure 2, the $\delta^{13} \mathrm{C}$ of $\Sigma \mathrm{CO}_{2}$ shifts abruptly to heavier values as a consequence of the preferential removal of ${ }^{12} \mathrm{C}$-enriched $\mathrm{CO}_{2}$ to form $\mathrm{C}_{1}$. At the depth at which sulfate goes to zero the concentration of $\Sigma \mathrm{CO}_{2}$ also decreases, reflecting the onset of rapid $\mathrm{C}_{1}$ generation. In addition, this depth ( 2 units) is usually the shallowest depth of readily observable $C_{1}$, as marked by the appearance of gas pockets in DSDP cores, or as reflected by greatly increased $C_{1}$ concentrations in the few studies of deep marine sediments in which quantitative measurements were permitted by the sampling methods (Emery \& Hoggan 1958). The $C_{1}$ with the most negative $\delta^{13} \mathrm{C}(-100$ to $-90 \%)$ also occurs at the depth of the transition from $\mathrm{SO}_{4}^{2-}$ reduction to $\mathrm{CO}_{2}$ reduction, or at a depth of 2 units in Figure 2. Isotopically heavier $\mathrm{C}_{1}$ (more positive $\delta^{13} \mathrm{C}$ ) occurs at greater depths because of progressive depletion of ${ }^{12} \mathrm{C}$ in the $\mathrm{\Sigma CO}_{2}$ reservoir from which the $C_{1}$ is formed. At depths shallower than 2 units in Figure 2, the small amounts of $C_{1}$ present have more positive $\delta^{13} C$ values, indicating partial oxidation in the zone of sulfate reduction (Doose \& Kaplan 1981. Brooks et al 1983). This oxidation process selectively removes

\footnotetext{
${ }^{2}$ Stable isotope ratios for carbon and sulfur are reported in the standard $\delta$-notation, where if : $\quad=\left[\left(R_{\text {comple }} R_{\text {sanderd }}\right)-1\right] \times 10^{3}, R={ }^{13} \mathrm{C} /{ }^{12} \mathrm{C}$ and ${ }^{14} \mathrm{~S} / /^{32} \mathrm{~S}$; and the standards are PDB marine carbonate and $C$ anon Diablo meteoritic troilite. respectively.
} 


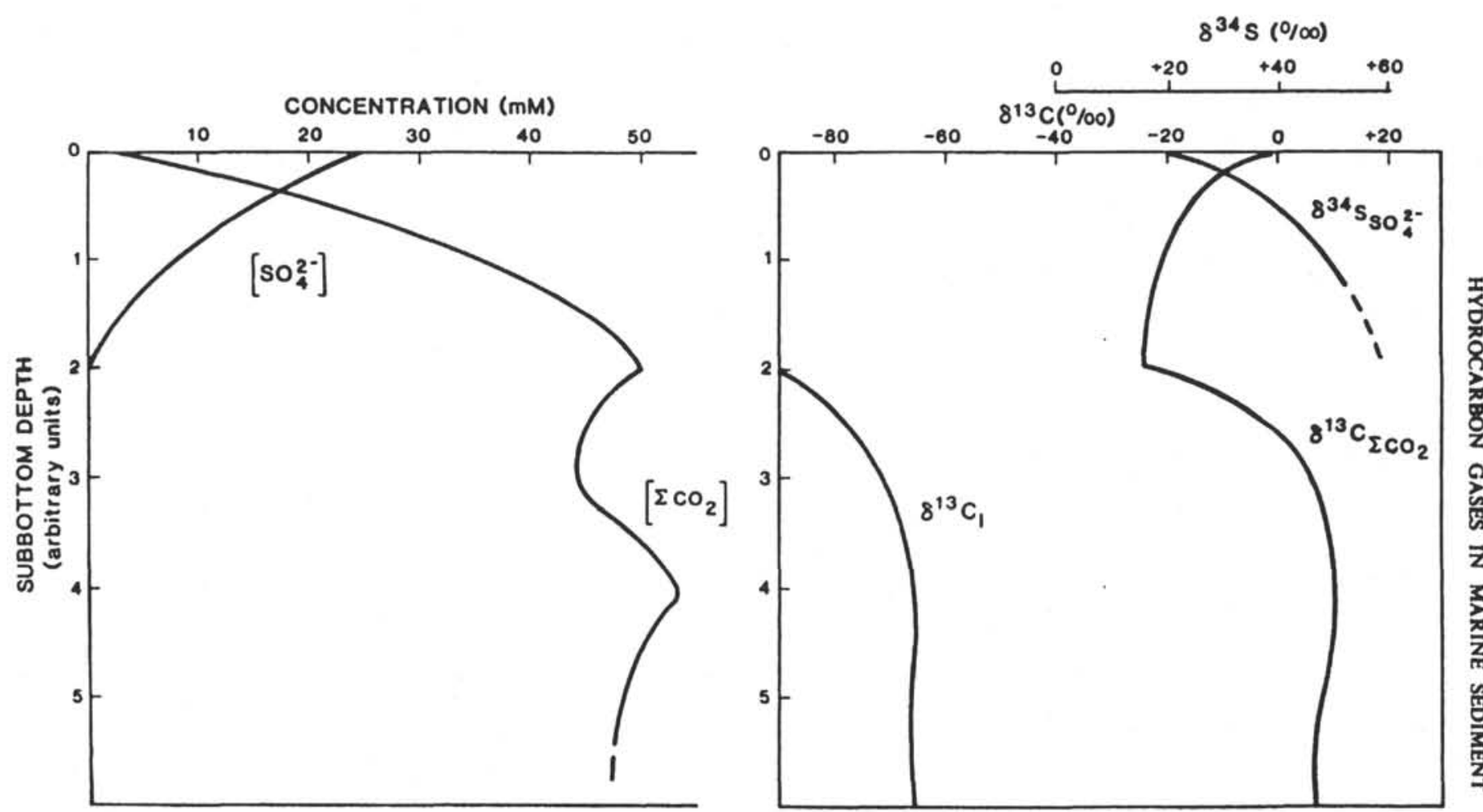

Figure 2 Generalized profiles of concentration and stable isotope ratio changes for dissolved sulfur and carbon species in anoxic marine sediments Depth scale is arbitrary with depth units ranging from $10^{-1}$ to $10^{2} \mathrm{~m}$. 
${ }^{12} \mathrm{C}$ and leaves the residual $C_{1}$ relatively enriched $\left(\delta^{13} \mathrm{C}\right.$ of -50 to $-40 \%$ or heavier). A similar isotope effect has been documented for aerobic $C_{1}$ oxidation (Silverman \& Oyama 1968, Coleman et al 1981, Barker \& Fritz 1981).

The curve in Figure 2 representing $\mathrm{SCO}_{2}$ concentration shows a second deeper maximum at a depth of 4 units, after the cessation of sulfate reduction and the onset of rapid $C_{1}$ generation. Because the porewater $\Sigma \mathrm{CO}_{2}$ concentration at any depth is a consequence of the balance between processes adding and removing $\mathrm{CO}_{2}$, this increased $\Sigma \mathrm{CO}_{2}$ can be due either to a relative increase in the rate of $\mathrm{CO}_{2}$ production or to a decrease in the rate of $\mathrm{C}_{1}$ generation. The second maximum in $\mathrm{\Sigma} \mathrm{CO}_{2}$ concentration is due to continued or increased generation of $\mathrm{CO}_{2}$ from decomposition of organic matter, as shown by the tendency of the $\delta^{13} \mathrm{C}$ of $\sum \mathrm{CO}_{2}$ to become lighter (more negative) at these depths (below 4 in Figure 2). Addition of isotopically light $\mathrm{CO}_{2}\left(\delta^{13} \mathrm{C}=-25 \%\right)$ at depth is sometimes also reflected in a tendency for the cumulative $C_{1}$ to become slightly lighter at these depths.

The depth-related changes described above are typical of anoxic marine sediments. These changes are the main evidence for the recognition of depositional and diagenetic sedimentary environments responsible for $C_{1}$ generation. Wherever the conditions discussed above do not exist, $C_{1}$ is absent or present only at background levels $\left(10^{-8}-10^{-5} \mathrm{v} / \mathrm{v}\right)$.

\section{Nonbiological Processes}

Although microbiological processes appear to be by far the most important source of $C_{1}$ in sediments of ocean basins, nonbiological processes also contribute some $C_{1}$. Three types of nonbiological $C_{1}$-generating processes are considered: first, the nonbiological decomposition of sedimentary organic matter at low temperatures $\left(<75^{\circ} \mathrm{C}\right)$; second, the high-temperature $\left(>75^{\circ} \mathrm{C}\right)$ degradation of organic matter; and third, the outgassing of primordial $\mathrm{C}_{1}$ from the mantle.

LOW-TEMPERATURE NONBIOLOGICAL $c_{1}$ The nonbiological decomposition of sedimentary organic matter forms the whole series of permanent gaseous alkane hydrocarbons $\left(C_{1}, C_{2}, C_{3}, C_{4}\right.$, etc $)$ in relative amounts that diminish regularly with increasing molecular size. The exact proportion of the various hydrocarbon gas components produced depends to some extent on the chemical composition of the organic matter being degraded. In general, $C_{1}$ is 5-20 times as abundant as $C_{2}$ in gases originating from nonbiological decomposition of organic matter.

$\mathrm{C}_{1}$ of possible nonbiological origin is observable at levels of $10^{-8}-10^{-5}$ $v / v$ in pelagic marine sediments with low organic matter content $\left(C_{\text {ors }}\right.$ 
$<0.2 \%$ ) beneath the zone of surface biological activity (Claypool 1983). Microbiological $C_{1}$ is absent from such sediments because of the lack of metabolizable organic matter and the presence of alternative electron acceptors. $C_{1}$ of microbiological origin typically is present in marine sediments of continental slopes and rises, with organic carbon contents in the range of $0.5-1 \%$. Higher contents of nonbiological hydrocarbons also are present in methanogenic sediments, but the low-temperature nonbiological $C_{1}$ is completely masked by biological $C_{1}$. However, because most $\mathrm{C}_{2}+$ hydrocarbons are not a direct product of the microbiological decomposition of organic matter, the approximate content of nonbiological $C_{1}$ in gas of predominantly biological origin is about ten times the level of $\mathrm{C}_{2}$.

$C_{1}$ OF HIGH-TEMPERATURE ORIGIN Most sediments accumulating in present-day ocean basins have not been exposed to high temperatures. Therefore, the limited occurrence in marine sediments of $C_{1}$ originating from the apparent high-temperature decomposition of organic matter (i.e. $\delta^{13} \mathrm{C}_{1}$ of -50 to $-30 \%$ ) can be explained in one of two ways: either the gas was generated at a more distant high-temperature location and migrated into cooler marine sediments, or instead the gas was generated in sediments subjected to high temperatures sometime during their burial history.

Large parts of the ocean basins are underlain by sediment thicknesses in excess of $3 \mathrm{~km}$, especially near continental margins. Organic matter in such deeply buried sediments could have generated hydrocarbons that then migrated into the sediments within $1 \mathrm{~km}$ of the seafloor. DSDP holes drilled above salt domes in the deep Gulf of Mexico on Legs 1 and 10 found gas of apparent thermogenic origin, which probably migrated up from greater depths along with the salt diapir (Erdman et al 1969, Claypool et al 1973). Other DSDP holes have been drilled in regions with anomalously high thermal gradients (e.g. Gulf of California), and $\mathrm{C}_{1}$ of high-temperature thermogenic origin was found at relatively shallow depths of burial (Galimov \& Simoneit 1982). The chemical and isotopic composition of gases sampled in the DSDP cores is briefly reviewed in a following section.

PRIMORDIAL $C_{1}$ Interest in $C_{1}$ gas of primordial origin has increased recently as a result of the observation that primordial gases $\left({ }^{3} \mathrm{He}, \mathrm{C}_{1}, \mathrm{H}_{2}\right)$ are being injected into the deep oceans from hydrothermal systems operating at active mid-ocean ridges (Welhan \& Craig 1979, Lupton \& Craig 1981). This has led to speculation that gas from similar sources may have natural resource implications (Gold 1979, Gold \& Soter 1980). The occurrence of primordial $C_{1}$ in marine sediments has not been documented, but is probably minor. Gas with composition indicative of likely mantle 
origin $\left(\mathrm{C}_{1} /{ }^{3} \mathrm{He}=3-10 \times 10^{6}, \delta^{13} \mathrm{C}_{1}=-19 \%\right)$ has been most clearly identified in solution in water $\left(C_{1}=10^{-3} \mathrm{v} / \mathrm{v}\right)$ issuing from fresh basalt at $21^{\circ} \mathrm{N}$ on the East Pacific Rise (Welhan 1980). At spreading centers where hydrothermal systems are operating through appreciable thicknesses of organic-matter-rich sediment, as in Guaymas Basin in the Gulf of California, the hydrocarbon gases in the sediment and those being injected into the water column have a composition indicating origin from organic matter decomposition (Simoneit \& Lonsdale 1982).

In general, the flux of $C_{1}$ into marine sediments from low-temperature, nonbiological organic-matter decomposition and from outgassing of the Earth is so slow that only a highly efficient concentrating and trapping mechanism could bring about a recognizable accumulation of such gas. In addition, the fact that such gas would be dispersed at low concentrations in marine sediment makes it extremely difficult to study. Gas of hightemperature origin is relatively rare in sediments of present-day ocean basins, but is probably much more important than $C_{1}$ gas from the other two nonbiological processes mentioned.

\section{OCCURRENCE OF $C_{1}$ AND ORIGIN AND OCCURRENCE OF OTHER HYDROCARBON GASES}

Trace or minor amounts of the other hydrocarbon gases $\left(C_{2}, C_{3}\right.$, and $\left.C_{4}\right)$ commonly are found associated with $C_{1}$ where sensitive detection techniques have been used in gas analyses. Emery \& Hoggan (1958) showed that near-surface marine sediment $(<4 \mathrm{~m}$ subbottom) from Santa Barbara Basin off southern California contains mainly $C_{1}$, but also small amounts $\left(10^{-7}-10^{-4} \mathrm{v} / \mathrm{v}\right)$ of $C_{2}, C_{2}=, C_{3}, i-C_{4}$, and $n-C_{4}$, as well as volatile hydrocarbons to $\mathrm{C}_{7}$. Their sampling procedures involved collection of large-volume samples and transfer of the sediment from the seafloor to the laboratory without exposing the core to air. This sampling technique compensated for the small amounts of $C_{2}$ through $C_{4}$ hydrocarbons and the relatively insensitive detection techniques, which discouraged any immediate follow-up of these kinds of measurements.

\section{Gases in Near-Surface Sediment}

Published research on the occurrence of $C_{2}$ through $C_{4}$ hydrocarbons in near-surface marine sediments languished for almost twenty years until Bernard et al (1978) described the distribution of $C_{1}, C_{2}, C_{2}=, C_{3}$, and $C_{3}=$ in shelf and slope sediment ( $<2 \mathrm{~m}$ subbottom) of the Gulf of Mexico. Using similar headspace analysis techniques, Kvenvolden \& Redden (1980) studied the occurrence and distribution of $C_{1}, C_{2}, C_{2}=, C_{3}, C_{3}=, i-C_{4}$, and $n-C_{4}$ in surface and near-surface sediment $(<2.5 \mathrm{~m}$ subbottom) of the outer 
shelf, slope, and basin of the Bering Sea. For headspace analyses, sediment samples are obtained using standard gravity or piston-coring techniques. Recovered cores typically are less than $5 \mathrm{~m}$ long, and extracted gas is analyzed by gas chromatography. The methods of headspace analysis provide a rapid quantitative measure of a portion of the gases originally in the sediment.

Headspace analyses of samples from the Gulf of Mexico (Bernard et al 1978 ) and the Bering Sea (Kvenvolden \& Redden 1980) provide a measure of concentrations of hydrocarbon gases in near-surface, partially oxic sediments of open-marine environments of the shelf, slope, and basin. For example, typical background concentrations of $\mathrm{C}_{1}$ in these sediments range from about $10^{-6}$ to $10^{-4}$ standard volumes of gas per volume of interstitial water $(\mathrm{v} / \mathrm{v})$. These concentrations are as much as three to five orders of magnitude lower than the concentrations of $C_{1}$ found at shallow $(<5 \mathrm{~m})$ depths in some anoxic and low-sulfate sediments of restricted marine environments (Reeburgh 1969, 1976, 1980, Barnes \& Goldberg 1976, Martens \& Berner 1977, Kosiur \& Warford 1979).

Generalizations also can be made about the occurrences of $\mathrm{C}_{2}$ through $\mathrm{C}_{4}$ hydrocarbons in sediments at shallow depth in open-marine environments. In the Gulf of Mexico and the Bering Sea, concentrations of $C_{2}$ are typically less than about $10^{-7} \mathrm{v} / \mathrm{v}$, concentrations of $\mathrm{C}_{3}$ are less than about $5 \times 10^{-8} \mathrm{v} / \mathrm{v}$, and concentrations of the sum of $\mathrm{i}-\mathrm{C}_{4}$ and $n-\mathrm{C}_{4}$ are less than about $2.5 \times 10^{-8} \mathrm{v} / \mathrm{v} . \mathrm{C}_{2}=$ and $\mathrm{C}_{3}=$ concentrations are about the same order of magnitude as the concentrations of $\mathrm{C}_{2}$ and $\mathrm{C}_{3}$, with some variation depending on the environmental setting. Concentrations of $\mathrm{C}_{2}$ through $\mathrm{C}_{4}$ hydrocarbons do not appear to increase significantly with sediment depth within the uppermost $2 \mathrm{~m}$; however, on a regional basis the average concentrations of $\mathrm{C}_{2}$ through $\mathrm{C}_{4}$ hydrocarbons do decrease with increasing depth of water from shelf to slope to basin.

Concentrations of $\mathrm{C}_{2}$ through $\mathrm{C}_{4}$ hydrocarbons may be much higher in sediments of restricted marine environments than in sediments of openmarine environments. For example, in sediments of Norton Sound, Alaska, concentrations of $\mathrm{C}_{2}+\mathrm{C}_{3}$ reach about $2 \times 10^{-6} \mathrm{v} / \mathrm{v}$ and of $\mathrm{i}-\mathrm{C}_{4}+n-\mathrm{C}_{4}$ about $2 \times 10^{-7} \mathrm{v} / \mathrm{v}$. However, $C_{1}$ in Norton Sound sediments reaches concentrations in excess of $2 \times 10^{-2}$ standard volumes per volume of interstitial water at sediment depths of less than $3 \mathrm{~m}$ (Kvenvolden et al 1981a), so the concentration of $C_{2}$ hydrocarbons relative to $C_{1}$ actually can be less in restricted marine sediments, compared with open-marine sediments.

In considering the possible origin of hydrocarbons in near-surface, openmarine sediments, a comparison with hydrocarbons in seawater is instructive. Results of extensive studies of hydrocarbon gases in seawater have been 
summarized by Swinnerton \& Lamontagne (1974). Table 2 shows that the hydrocarbon concentrations of near-surface marine sediment greatly exceed the average hydrocarbon concentration of open-ocean water. Thus, a water-column source for hydrocarbon gas in near-surface marine sediment is improbable.

Another possible explanation is that the hydrocarbon gases in the nearsurface sediment of open-marine environments diffused or migrated upward from more deeply buried sediment. Although some movement from depth is certainly possible, the distribution of hydrocarbon gases in near-surface marine sediment, in general, does not provide compelling evidence for this source. Bernard (1979) concluded that upward diffusion from large accumulations of $C_{1}$ deeper than about $10 \mathrm{~m}$ would not be detectable in near-surface sediment. Profiles of concentrations of $\mathrm{C}_{2}$ through $\mathrm{C}_{4}$ hydrocarbons show little or no change with depth in nearsurface sediments (Bernard et al 1978. Kvenvolden \& Redden 1980). This kind of profile implies that the source of these hydrocarbons is probably not deeper in the sediment.

If the overlying water column and the underlying sediments are discounted as major sources of the hydrocarbons found in near-surface marine sediments, then these hydrocarbons must be generated in place. Microbial production (possibly in anoxic microenvironments) and consumption provide a reasonable explanation for the observed $C_{1}$ distributions in near-surface marine sediments of open-marine environments.

$C_{2}, C_{2}=C_{3}$, and $C_{3}=$ hydrocarbons are known to be generated in connection with microbial processes (Davis \& Squires 1954, Primrose \& Dilworth 1976). Marine organisms produce both $C_{2}=$ and $C_{3}=$ (Hunt 1974). and studies of anoxic estuarine sediments indicate that small quantities of $\mathrm{C}_{2}$ can be formed by certain methanogenic bacteria

Table 2 Concentrations of hydrocarbon gases in open-ocean water (Swinnerton \& Lamontagne 1974) and near-surface sediment of open-marine environments (Bernard et al 1978, Kvenvolden \& Redden 1980)

\begin{tabular}{|c|c|c|}
\hline Gas & Open-ocean" & Near-surface sediment ${ }^{2}$ \\
\hline$c_{1}$ & 50 & $1000-100,000$ \\
\hline$c:$ & 0.5 & $20-100$ \\
\hline$c_{2:}$ & 5 & $10-200$ \\
\hline$C_{1}$ & 0.3 & $10-50$ \\
\hline (i) & 1.4 & $5-100$ \\
\hline $\mathrm{C}_{4}\left(\mathrm{i} \cdot \mathrm{C}_{4}+n-\mathrm{C}_{4}\right)$ & 0.05 & 025 \\
\hline
\end{tabular}


(Oremland 1981). Prolonged incubation of these estuarine sediments also produce $C_{2}=, C_{3}, C_{3=}, i-C_{4}$, and $n-C_{4}$ (Vogel et al 1982). This kind of circumstantial evidence, combined with the common observation of small quantities of $\mathrm{C}_{2}$ through $\mathrm{C}_{4}$ hydrocarbons in recent marine sediments, has led some authors to suggest microbial processes as a reasonable source for these hydrocarbon gases (Emery \& Hoggan 1958, Bernard et al 1978, Whelan et al 1980, K venvolden \& Redden 1980).

\section{Gases in Deeper Oceanic Sediment}

Results obtained through the Deep Sea Drilling Project (DSDP) have provided an extensive record of hydrocarbon gases in deeper oceanic sediments, covering all of the oceans except the Arctic, and from sediment depths of a few meters to about $1500 \mathrm{~m}$.

$C_{1}$ is the dominant hydrocarbon gas found in DSDP samples. Starting in about 1970 with DSDP Leg 10 in the Gulf of Mexico, gas samples have been collected routinely in evacuated containers (Gealy \& Dubois 1971) or recovered from the headspace of sealed cans (Mclver 1973) and analyzed by gas chromatography. Claypool et al (1973) summarize gas analyses of gas pockets in sediments collected on seven legs $(10,11,13,14,15,18$ and 19) in the following areas: Gulf of Mexico, western Atlantic Ocean, Mediterranean Sea, Caribbean Sea, eastern and northern Pacific Ocean. and the Bering Sea. For all drilling sites except one, $C_{1}$ constituted more than 99.9 percent of the hydrocarbon gases detected. Utilizing gases in canned sediment samples, Mclver (1975) showed that $C_{1}$ is virtually the only hydrocarbon gas present in 125 samples from 22 sites on eight DSDP legs $(18,19,21,23,24,27,28$, and 29) in the western and northern Pacific Ocean, Bering Sea, eastern Pacific Ocean, Arabian Sea, Red Sea, Gulf of Aden. Timor Sea, and the Antarctic Ocean. Thus the predominance of $C_{1}$ in marine sediments of the world's oceans is well established.

Although concentrations of $C_{2}$ are usually less than 0.1 percent of the hydrocarbon gases present in oceanic sediment, the ratio of $C_{2}$ to $C_{1}$ generally increases exponentially with depth in the sediment. This increasing ratio results mainly from increasing amounts of $C_{2}$ with depth, rather than from changes in the amounts of $C_{1}$. In Figure 3 , the ratio of $C_{2}$ to $C_{1}$ is plotted as a function of depth of burial for a variety of depositional settings in the world's oceans, and the exponential increase in $C_{2}$ content with increasing depth is evident. At any given locality, the amount of $C_{2}$ appears to be proportional to the temperature and age of sediment (Rice \& Claypool 1981).

Hydrocarbon gases larger than $C_{2}$, i.e. $C_{3}, i-C_{4}$, and $n-C_{4}$, also have been found in samples from DSDP drilling. $C_{2}=$ and $C_{3}=$ have not been reported. Routine detection and analysis of hydrocarbon gases larger than 
$\mathrm{C}_{2}$ required the application of a concentration technique to isolate the small amounts of the compounds usually present with $C_{1}$ from ocean sediment (Whelan 1979). Hunt \& Whelan (1978) noted that $C_{1}$ was the dominant hydrocarbon gas in Black Sea sediment (Leg 42B), but that the gas mixture contained small amounts $\left(10^{-6}-10^{-3} \mathrm{v} / \mathrm{v}\right)$ of $\mathrm{C}_{2}$ through $\mathrm{C}_{4}$ hydrocarbons. The concentrations of these hydrocarbons differed from each other by about an order of magnitude for each increasing carbon number; $C_{2}$ was most abundant. The trends of concentrations with depth for each of these hydrocarbons were similar.

Whelan (1979) observed trends of $C_{1}$ through $C_{4}$. as well as larger

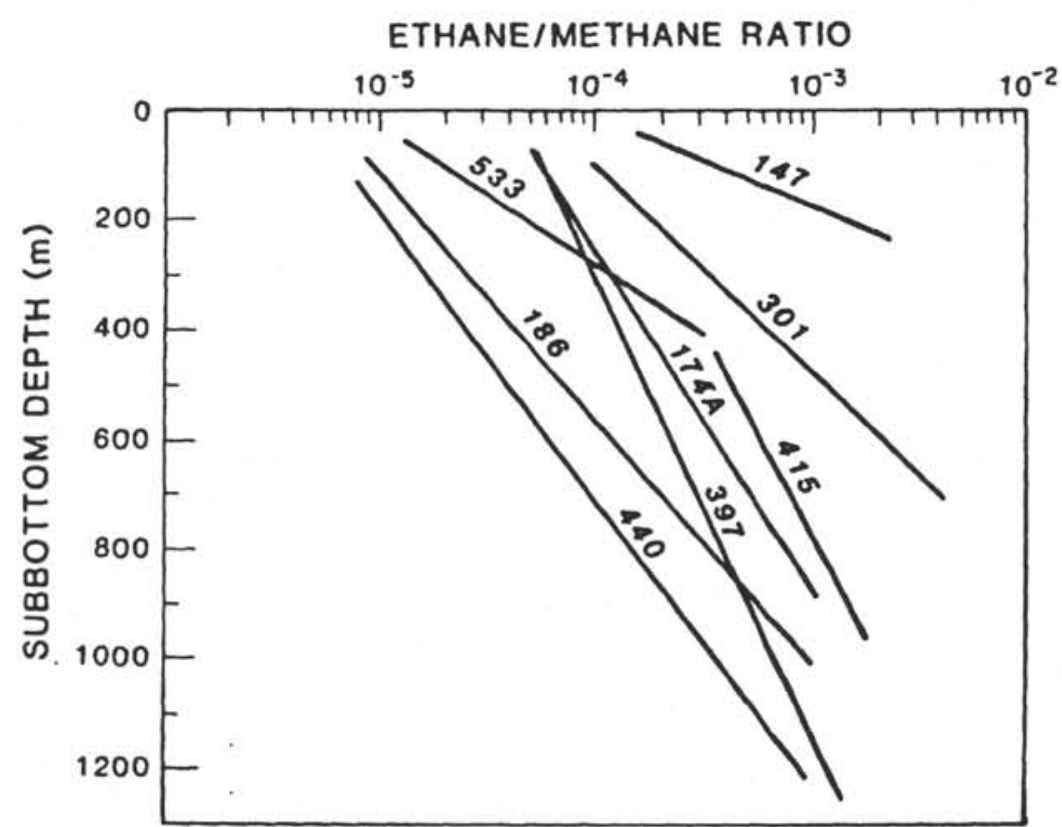

Figure 3 Ethane to methane ratios $\left(C_{2} / C_{1}\right)$ vs depth in sediment from selected sites drilled by the Deep Sea Drilling Project.

\begin{tabular}{lcll}
\hline Site & Leg & \multicolumn{1}{c}{ Location } & \multicolumn{1}{c}{ Reference } \\
\hline 147 & 15 & Cariaco Trench, Caribbean & Rice \& Claypool (1981) \\
174A & 18 & Astoria Fan, Pacific & Rice \& Claypool (1981) \\
186 & 19 & Aleutian Trench, Pacific & Rice \& Claypool (1981) \\
397 & 47 & African Margin, Atlantic & Whelan (1979) \\
415 & 50 & Morocian Basin, Atlantic & Galimov et al (1980) \\
440 & 57 & Japan Trench. Pacific & Whelan \& Sato (1980) \\
533 & 76 & Blake Ridge. Atlantic & K venvolden \& Barnard (1983a) \\
\hline
\end{tabular}


hydrocarbons, in continental margin sediments off northwest Africa that were similar to those observed for Black Sea sediments. Observations of $\mathrm{C}_{2}$ through $\mathrm{C}_{4}$ hydrocarbons in samples from DSDP drilling have now been augmented to include sediments from the Vigo Seamount (Whelan \& Hunt 1979a), the Bay of Biscay (Whelan \& Hunt 1979b), the Moroccan Basin (Galimov et al 1980, Whelan \& Hunt 1980a), the Japan Trench (Whelan \& Hunt 1980b), the California borderland (Whelan \& Hunt 1981), and the Blake Outer Ridge (Kvenvolden \& Barnard 1983a).

The $C_{2}$ through $C_{4}$ hydrocarbons accompaning $C_{1}$ in oceanic sediment probably have a complex history. They most likely represent products of a continuum of diagenetic processes, the first stages of which involve mainly microbiological processes operating near the sediment surface. These microbiological processes give way with sediment depth to processes that are thermally controlled at low temperatures. Thermal processes cause mild thermal decomposition of organic matter, resulting in the exponential increase with depth of $\mathrm{C}_{2}$. Hydrocarbon gases $\mathrm{C}_{3}, \mathrm{i}-\mathrm{C}_{4}$, and $n-\mathrm{C}_{4}$ also tend, as a general rule, to increase slightly in concentration with depth. This increased concentration also may be attributed to low-temperature $\left(<50^{\circ} \mathrm{C}\right)$ thermal reactions. At temperatures existing in sediment at depths greater than those sampled by DSDP for gas analyses (i.e. greater than about $1500 \mathrm{~m}$ in regions with average thermal gradients), the thermal processes become more intense and result in the generation of gas associated with petroleum formation.

On the basis of all these observations, the followi" , generalizations can be made: $(a) C_{1}$ is the most abundant hydrocarbn 1 gas in deeper oceanic sediments, commonly constituting more than $99 \%$, o the hydrocarbon gas mixture; (b) $\mathrm{C}_{2}$ through $\mathrm{C}_{4}$ hydrocarbons are ubiquitous but minor components of the gas mixture in oceanic sediment; (c) $\mathrm{C}_{2}$ generally increases exponentially in concentration with depth of sediment; and (d) the trends of $\mathrm{C}_{2}$ through $\mathrm{C}_{4}$ concentrations with depth are usually similar.

The isotopic composition of $\mathrm{C}_{1}$ in the hydrocarbon gas mixtures in oceanic sediments provides the best evidence of origin (Rice \& Claypool 1981). Table 3 shows the range of isotopic compositions of $C_{1}$ found in sediments drilled by DSDP. In most of the examples, the $\delta^{13} \mathrm{C}$ values fall in a range between about $-90 \%$ ond $-50 \%$. This range is characteristic of microbiologically derived $C_{1}$ from natural sources, as summarized by Fuex (1977). $C_{1}$ with carbon isotopic compositions more positive than about $-55 " / \%$ in natural gas of near-surface sediment may result from partial microbial oxidative processes, as discussed by Silverman \& Oyama (1968). Coleman et al (1981), and Barker \& Fritz (1981). Carbon isotopic compositions of $\mathrm{C}_{1}$ more positive than $-55 \%$ also may be attributed to high-temperature thermal processes giving rise to $C_{1}$ that has migrated 
Table 3 Carbon isotope composition of $C_{1}$ recovered through DSDP drilling of oceanic sediment

\begin{tabular}{lccl}
\hline \hline \multicolumn{1}{c}{ Location } & $\begin{array}{c}\text { DSDP } \\
\text { Leg }\end{array}$ & $\delta^{13} \mathrm{C}_{1}(\%)$ (ou) & \multicolumn{1}{c}{ Reference } \\
\hline Guif of Mexico & 10 & -84.0 to -48.7 & Claypool et al (1973) \\
East Mediterranean Sea & 13 & -77.8 to -72.6 & Claypool et al (1973) \\
Caribbean Sea & 15 & -81.3 to -69.1 & Claypool et al (1973) \\
Carioca Trench & 15 & -76.3 to -59.6 & Lyon (1973) \\
Astoria Fan & 18 & -88.7 to -75.9 & Claypool et al (1973) \\
East Aleutian Trench & 18 & -80.8 to -72.6 & Claypool et al (1973) \\
Bering Sea, North Pacific & 19 & -78.8 to -62.7 & Claypool et al (1973) \\
Arabian Sea & 23 & -82.8 to -61.0 & Claypool (unpublished) \\
South Red Sea & 23 & -76.8 to -60.9 & Claypool (unpublished) \\
Gulf of Aden & 24 & -76.2 to -70.2 & Claypool (unpublished) \\
Timor Trench & 27 & -77.0 to -58.6 & Claypool (unpublished) \\
Ross Sea & 28 & -78.9 to -67.5 & Claypool (unpublished) \\
Sea of Japan & 31 & -72.0 to -67.4 & Jodele \& Doose (unpublished) \\
Norwegian Sea & 38 & -87.3 to -71.2 & Morris (1976) \\
Black Sea & $42 A$ & -72.0 to -63.0 & Hunt \& Whelan (1978) \\
Continental Rise, NW Africa & 41 & -73.9 to -51.7 & Doose et al (1978) \\
Continental Rise, NW Africa & 47 & -80.0 to -60.0 & Whelan (1979) \\
Morocan Basin & 50 & -82.1 to -49.2 & Galimov et al (1980) \\
Japan Trench & 56,57 & -83.8 to -67.6 & Whelan \& Sato(1980) \\
California Borderland, Baja & 63 & -81.6 to -47.3 & Claypool (unpublished) \\
Gulf of California & 64 & -79.2 to -40.4 & Galimov \& Simoneit (1982) \\
Blake Outer Ridge & 11 & -88.4 to -70.1 & Claypool et al (1973) \\
Blake Outer Ridge & 76 & -93.8 to -65.8 & Galimov \& Kvenvolden (1983) \\
\hline & & &
\end{tabular}

from deeper sources (Fuex 1977). Measurement of the H/D ratio of $C_{1}$ can resolve these alternative interpretations based on $\delta^{13} \mathrm{C}$, because partially oxidized $C_{1}$ is even more enriched in $D$ than ${ }^{13} \mathrm{C}$ (Coleman et al 1981).

At many DSDP sites, profiles of $C_{1}$ isotopic values can be constructed with depth of burial (Claypool et al 1973, Claypool \& Kaplan 1974, Doose et al 1978, Whelan 1979, Galimov et al 1980, Whelan \& Sato 1980, Galimov \& Kvenvolden 1983). These profiles consistently show the trends seen in Figure 2, and are believed to result from a kinetic effect of biological methanogenesis (Rosenfeld \& Silverman 1959).

Except for a few instances, the molecular and isotopic compositions of hydrocarbon gases in oceanic sediments cannot be explained satisfactorily by upward migration of thermogenically derived gases. Such migration would require diffusion of gas through unconsolidated and semiconsolidated oceanic sediment. That sufficient diffusion could take place over the distance required is unlikely, even if the gas were present in large amounts at depth (Bernard 1979). 


\section{IMPLICATIONS OF HYDROCARBON GASES IN MARINE SEDIMENT}

\section{Geochemical Prospecting}

Although the hydrocarbon gases in the first $1000 \mathrm{~m}$ of oceanic sediment beneath the seafloor can, in general, be accounted for by in situ processes, situations exist where gases originating elsewhere are associated with sediment. As explained earlier, hydrocarbon gases may be generated by nonbiologic processes in more deeply buried sediment, where temperatures exceed $80^{\circ} \mathrm{C}$ and petroleum is being formed. These gases, derived from the thermal breakdown of organic matter during later diagenesis, may migrate along fractures and faults to the seafloor. There, as gas seeps, they may provide clues to the presence of their petroleum precursors in the subsurface.

Active gas seeps in the marine environment are manifest as gas bubbles venting from the seafloor and as anomalously high concentrations of gas dissolved in the water column. Anomalous concentrations of hydrocarbon gases in the water column can be identified by analyses of gases (a) recovered as bubbles (Bernard et al 1976, Reed \& Kaplan 1977), (b) extracted from discrete water samples (Brooks et al 1973, Cline \& Holmes 1977), and (c) detected by gas sniffers (Sigalove \& Pearlman 1975, Sackett 1977, Reitsema et al 1978).

Hydrocarbon gas compositions and $\delta^{13} \mathrm{C}$ values of $\mathrm{C}_{1}$, measured in bubbles from natural seeps and underwater vents from offshore production operations, provide the basis for distinguishing biogenic (microbially derived) from thermogenic (petroleum-derived) gas (Bernard et al 1976). Biogenic gas has $C_{1} /\left(C_{2}+C_{3}\right)$ ratios greater than 1000 , which means that the mixture is almost exclusively $C_{1}$. The isotopic composition of this $C_{1}$ is lighter (more negative) than $-60 \%$. Thermogenic gas has significant quantities of low-molecular-weight hydrocarbons, with $C_{1} /\left(C_{2}+C_{3}\right)$ ratios ranging from 0 to 50 . The isotopic composition of thermogenic $C_{1}$ is usually heavier (more positive) than $-50 \%$. Thus, the ratio $C_{1} /\left(C_{2}+C_{3}\right)$ and the isotopic composition of $\mathrm{C}_{1}$ can, in concert, be used as diagnostic parameters to ascertain the source of hydrocarbon gases in natural seeps. Figure 4 shows the molecular and isotopic compositions of gases in seeps and vents. Whereas vent gases clearly have a thermogenic source, only one seep (\# 5 in Figure 4) in the Gulf of Mexico has that source. Of the remaining thirteen sampled seeps in the Gulf of Mexico, eight have biogenic sources and five apparently have mixed origins (Bernard et al 1976). At Coal Oil Point and Carpinteria, offshore southern California, the composition of gas bubbling from submarine seeps indicates a thermogenic source (Reed \& Kaplan 1977). 


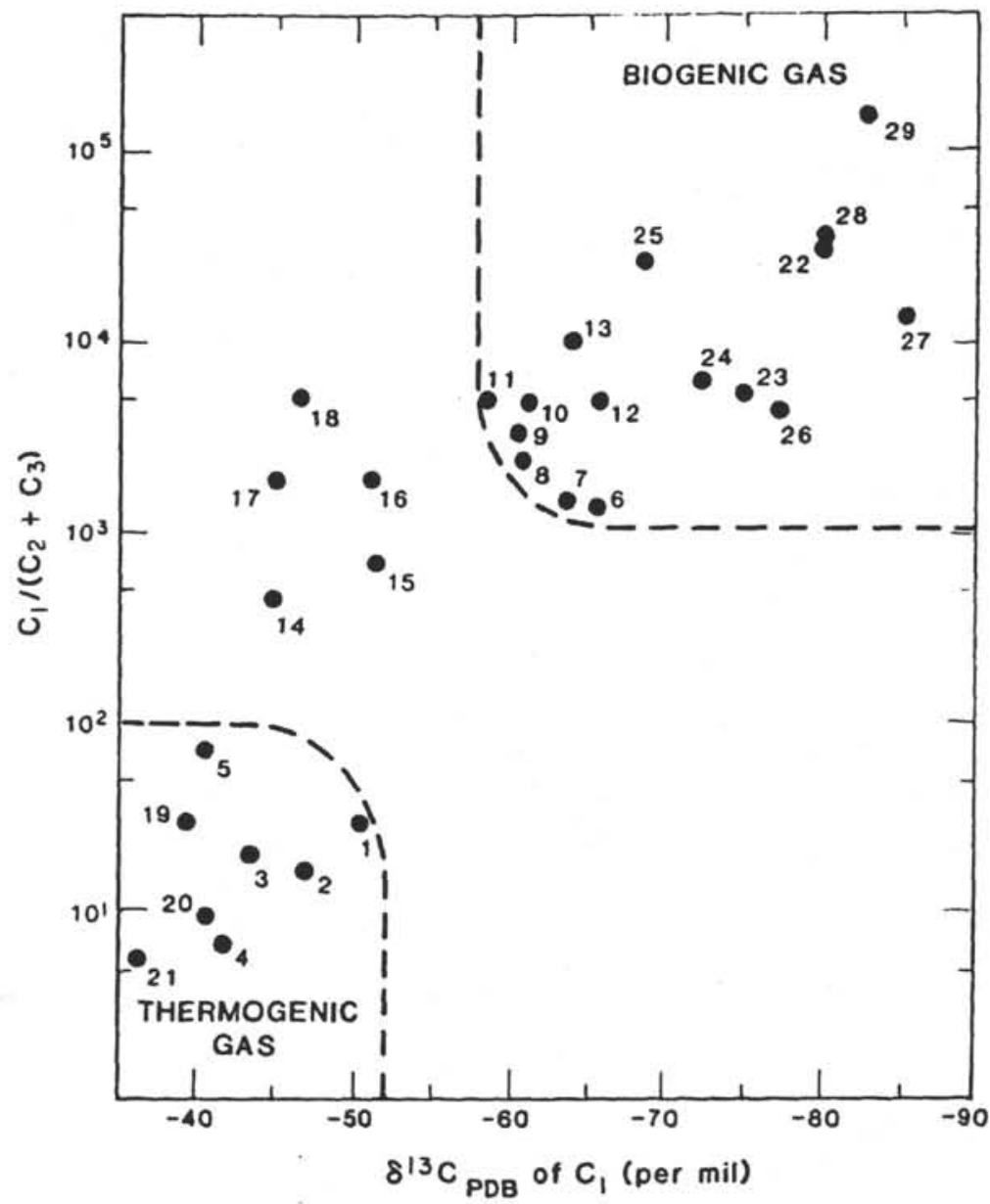

Figure 4 Relation between the logarithm of $C_{1} /\left(C_{2}+C_{3}\right)$ and the isotopic composition of $C_{1}$ for hydrocarbons in vents, seeps, and sediments.

\begin{tabular}{|c|c|c|}
\hline Location & Numbers & Reference \\
\hline \multicolumn{3}{|l|}{ Vents } \\
\hline Gulf of Mexico & $1-4$ & Bernard et al (1976) \\
\hline \multicolumn{3}{|l|}{ Seeps } \\
\hline Gulf of Mexico & $5-18$ & Bernard et al (1976) \\
\hline Offshore southern California & $19-20$ & Reed \& Kaplan (1977) \\
\hline Norton Sound, Alaska & $21-22$ & K venvolden et al (1979) \\
\hline Norton Sound, Alaska & $23-25$ & Kvenvolden et al (1981a) \\
\hline Western Gulf of Alaska & $26-29$ & Hampton \& Kvenvolden (1981) \\
\hline
\end{tabular}


Before seeping into the water column, hydrocarbon gases may pass through unconsolidated surficial sediment at the seafloor. These hydrocarbons partially dissolve in the interstitial water and likely diffuse within the sediment. Therefore, in geochemical prospecting hydrocarbon gases in near-surface marine sediment might be examined for clues to the possible occurrence of petroleum at depth. Particularly informative results should be obtained from the analysis of sediments adjacent to active seeps. Carlisle et al (1975) examined sediments near an active seep and found a distinct hydrocarbon anomaly in which the $C_{1} /\left(C_{2}+C_{3}\right)$ ratio was less than 1 , but no measurement was made of the isotopic composition of the $C_{1}$. In Norton Sound, Alaska, Kvenvolden et al (1979) measured the hydrocarbon gases in sediments associated with a $\mathrm{CO}_{2}$ seep. $\mathrm{AC}_{1} /\left(\mathrm{C}_{2}+\mathrm{C}_{3}\right)$ ratio of about 6 and a carbon isotopic composition of $\mathrm{C}_{1}$ of $-36 \%$ clearly indicate a thermogenic source of hydrocarbon gases (\#21 in Figure 4). Even where active seepage is not present but where high concentrations of $\mathrm{C}_{1}$ are present in sediment (exceeding about $10^{-3}$ standard volumes per volume of interstitial water), the molecular and isotopic gas compositions are diagnostic. For example, in Norton Sound (Kvenvolden et al 1981a) and the western Gulf of Alaska (Hampton \& Kvenvolden 1981), the gas in near-surface, gas-charged sediment is from biogenic sources (Figure 4).

Although the $C_{1} /\left(C_{2}+C_{3}\right)$ ratio appears to be useful where gas concentrations are high, as in and near seeps and in gas-charged sediment, use of the ratio as an indicator of source is not yet clearly substantiated where low concentrations of hydrocarbon gases are dispersed within nearsurface sediment (Kvenvolden \& Redden 1980). Nevertheless, this ratio along with the ratio of $C_{2} / C_{2}=$ has been used to indicate the possible presence of thermogenic gas in near-surface sediment of St. George Basin in the southern Bering Sea (Kvenvolden et al 1981b), where two sites were identified with suspected thermogenic gas. This study also showed, however, that gas in surface grab samples has anomalously low $C_{1} /\left(C_{2}\right.$ $+C_{3}$ ) ratios (less than 20). These low ratios probably do not signal the presence of thermogenic hydrocarbons, but rather indicate the preferential loss of $C_{1}$ owing to a balance between diffusion and selective microbial $C_{1}$ consumption.

Low concentrations of gas in near-surface sediment also limit the use of the isotopic composition of $C_{1}$ because the amount of $C_{1}$ collected usually is insufficient to obtain valid isotopic measurements. Where the carbon isotopic composition of $\mathrm{C}_{1}$ can be determined for near-surface sediment, the $C_{1}$ may be anomalously heavy because the bacterial oxidation of $C_{1}$ leaves as a residual product an isotopically heavy $C_{1}$ (Coleman et al 1981). Thus, the $C_{1} /\left(C_{2}+C_{3}\right)$ ratios and the carbon isotopic compositions of $C_{1}$ in gases from near-surface sediment may have values that are characteristic of 
thermogenic sources, but the gases themselves may be the product of in situ processes strongly mediated by microbial activity. Application of these parameters as source indicators to the gases found in near-surface sediments is therefore limited, especially where low gas concentrations occur. Deeper sampling (to depths greater than about $2 \mathrm{~m}$ ) may provide samples of gas that are not significantly affected by near-surface processes and thus are of potential use in geochemical prospecting for hydrocarbons.

\section{Gas Hydrates}

In general, solubilities of hydrocarbon gases in the interstitial waters of oceanic sediment increase with increasing depth of burial, but details regarding solubility have been worked out only for $C_{1}$ [see Rice \& Claypool (1981) for a discussion]. Figure 5 shows the estimated solubility of $C_{1}$ as a function of depth. $C_{1}$ solubility increases with increasing depth of burial beneath water depths less than $1000 \mathrm{~m}$. However, for deep-sea sediments at water depths greater than $1000 \mathrm{~m}$, solubility initially decreases between sediment depths of 1000 and $2000 \mathrm{~m}$ before increasing at greater burial depths. Where water is saturated with $C_{1}$ at the depths indicated on Figure 5 , the water can crystallize as a solid at temperatures above $0^{\circ} \mathrm{C}$ by the incorporation of $\mathrm{C}_{1}$ into a clathrate, or three-dimensional framework of water molecules, that is stabilized by the included $C_{1}$ molecules. This water clathrate is commonly called a gas hydrate.

In gas hydrates, water crystallizes in the isometric system, rather than in the hexagonal system of normal ice. The isometric or cubic lattice contains voids, or cages, large enough to accommodate molecules of gas. Two structures of the cubic lattice are possible. In structure I, the cages are arranged in body-centered packing and include small hydrocarbon molecules such as $\mathrm{C}_{1}$ and $\mathrm{C}_{2}$ and nonhydrocarbons such as $\mathrm{N}_{2}, \mathrm{CO}_{2}$, and $\mathrm{H}_{2} \mathrm{~S}$. In structure II, diamond packing is present ; not only can $\mathrm{C}_{1}$ and $\mathrm{C}_{2}$ be included in the cages, but $\mathrm{C}_{3}$ and $\mathrm{i}-\mathrm{C}_{4}$ also are needed to occupy some of the large cages in order to stabilize the structure. Apparently, gas molecules larger than i- $\mathrm{C}_{4}-$ for example, $n-\mathrm{C}_{4}, \mathrm{C}_{5 ' \text { 's, }}$ etc-cannot be included in either structure I or II (Hand et al 1974, Hitchon 1974).

The pressure (depth)-temperature region in which pure $\mathrm{C}_{1}$ forms a gas hydrate with pure water saturated with $C_{1}$ is shown in Figure 6. Gas extracted from oceanic sediment, however, is not pure $\mathrm{C}_{1}$; it also has small concentrations of $\mathrm{C}_{2}$ and hydrocarbon gases of higher molecular weight as well as $\mathrm{CO}_{2}$. The presence of these additional components in the gas mixture causes the phase boundary (Figure 6) to shift to the right. Porewater in normal oceanic sediment is not pure but contains salts, particularly $\mathrm{NaCl}$. The presence of salts in the water shifts the phase boundary to the left (Figure 6). For naturally occurring gases in oceanic 


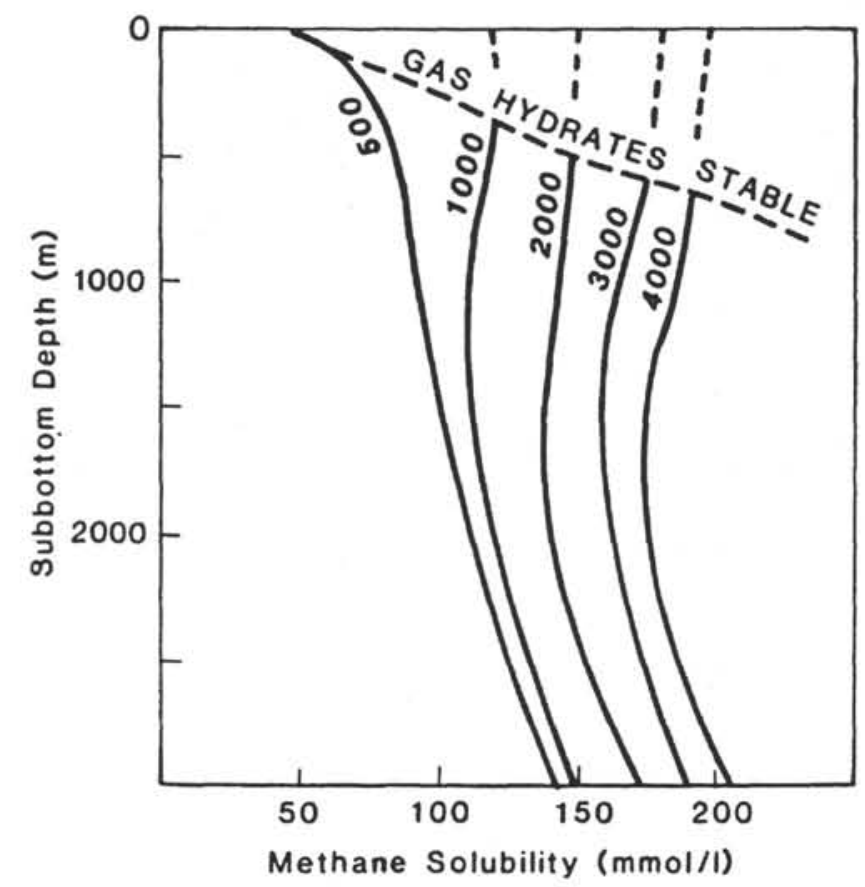

Fiyure $S$ Estumated methane $\left(C_{1}\right)$ solubility with depth of burial in oceanic sediment. The relation between $C_{1}$ solubility and the depth at which gas hydrates are stable is shown. Curves are for specific water depths (labeled in meters). The solubility data are from Culberson \& McKetta (1951) and have been reduced $80 \%$ of the observed solubility of $C_{1}$ in pure water at a given temperature and depth to adjust for effects of $3.5^{\circ}$, salinity. The series of curves indicate the changes of solubility at different pressure-temperature gradients associated with water depths from 0 to $4000 \mathrm{~m}$. The pressure gradient is assumed to be hydrostatic $\left(0.1 \mathrm{~atm} \mathrm{~m} \mathrm{~m}^{-1}\right)$ and a geothermal gradient of $35^{\circ} \mathrm{C} \mathrm{km}^{-1}$ is used. The temperature of sediment with no burial is assumed to be $20^{\circ} \mathrm{C}$ for a water depth of $0 \mathrm{~m}, 5^{\circ} \mathrm{C}$ for water depths of $500 \mathrm{~m}$, and $2^{\circ} \mathrm{C}$ for water depths of $1000 \mathrm{~m}$ and greater. Figure is redrawn from Rice \& Claypool (1981).

sediment, the shifts in the position of the phase boundary are of similar magnitude but in opposite directions. Thus, the effects approximately cancel each other, and the boundary for a pure-water and pure-methane system (Figure 6) provides a reasonable estimate of the pressuretemperature conditions under which natural gas hydrates, composed mainly of $C_{1}$, will be stable in oceanic sediment (Claypool \& Kaplan 1974).

Because pressure is largely determined by water depth, the temperature established by the geothermal gradient mainly controls the lower depth limits within oceanic sediment at which gas hydrates are no longer stable and therefore decompose. The base of the gas hydrate zone follows a pressure-temperature surface that represents the maximum depth at which 


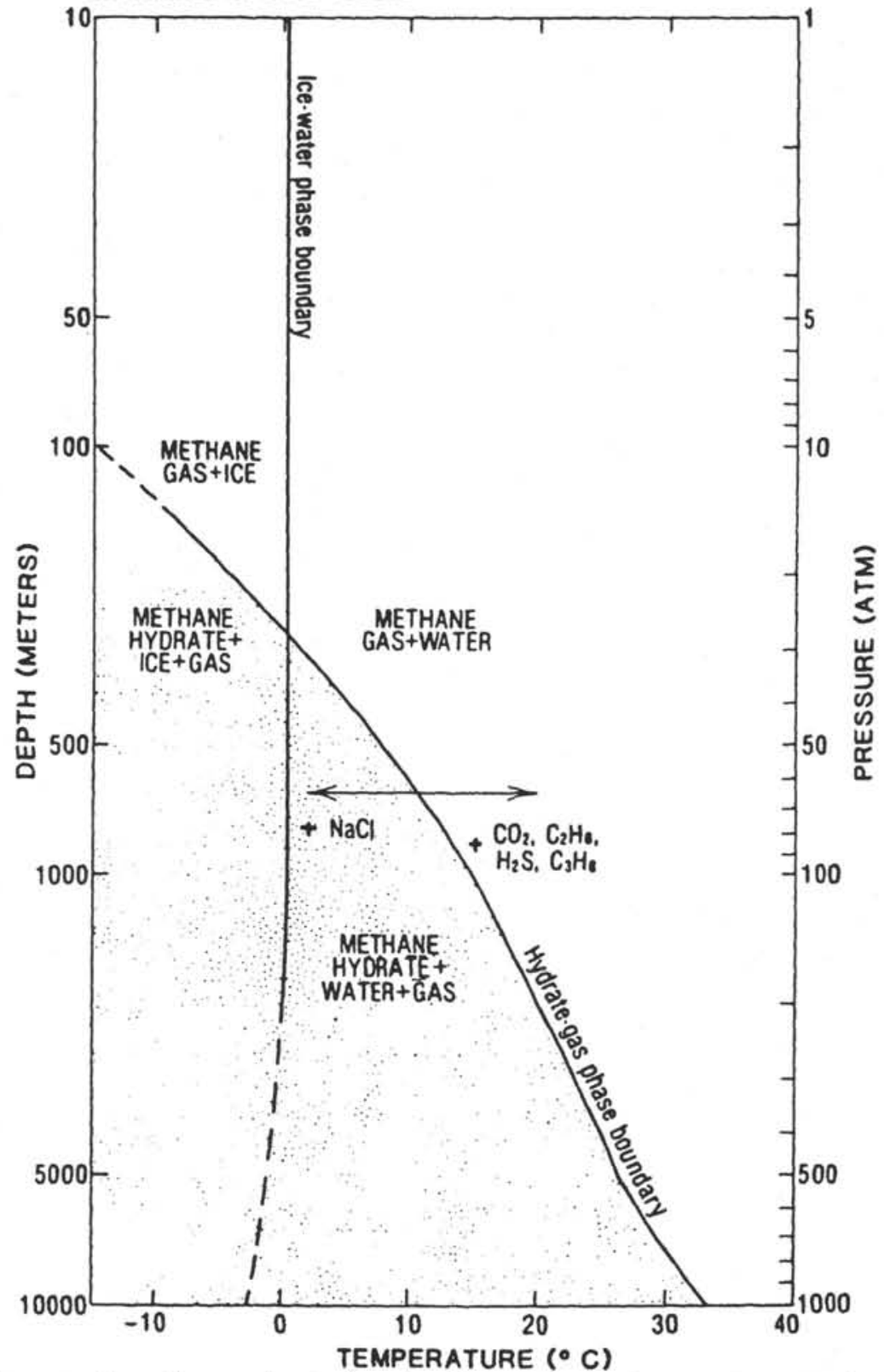

Figure 6 Phase diagram showing boundary between free methane gas (no pattern) and methane hydrate (pattern) for a pure-water and pure-methane system. Addition of $\mathrm{NaCl}$ to water shifts the curve to the left. Addition of $\mathrm{CO}_{2}, \mathrm{H}_{2} \mathrm{~S} . \mathrm{C}_{2}$, and $\mathrm{C}_{3}$ shifts the boundary to the right, thus increasing the area of the gas hydrate stability field. Depth scale assumes lithostatic and hydrostatic pressure gradients of $0.1 \mathrm{~atm} \mathrm{~m} \mathrm{~m}^{-1}$. Figure was constructed from Katz et al (1959) and redrawn from K venvolden \& McMenamin (1980). 
the gas hydrate is stable. Therefore, beneath the gas hydrate zone free gas may be present in gas-saturated sediments.

The base of the gas hydrate zone often correlates with anomalous acoustic reflectors in marine seismic data obtained from a number of areas on outer continental margins (Shipley et al 1979). The anomalous reflector approximately parallels the seafloor but deepens with increasing water depths. The depths at which this reflector occurs can be predicted based on considerations of the pressure-temperature stability field for gas hydrates and the geothermal gradient. The reflector commonly is called a bottomsimulating reflector (BSR). The BSR probably results from the velocity contrast between sediment cemented with gas hydrate and underlying sediment in which lower velocities occur because of the absence of gas hydrate and the possible presence of free gas.

K venvolden \& McMenamin (1980) and Kvenvolden \& Barnard (1983b) have summarized the geologic occurrences of natural gas hydrates and listed areas where the presence of marine gas hydrates can be inferred based on observations of BSRs on marine seismic records. Marine gas hydrates can be found in continental margin sediment of all the world's oceans. In spite of the apparent ubiquity of gas hydrates in continental margin sediment, solid samples of gas hydrate have been recovered from oceanic sediment in only three areas-the Black Sea in Russia (Yefremova \& Zhizhchenko 1975), the Blake Outer Ridge in the Atlantic Ocean offshore from southern United States (Sheridan et al 1982), and the landward flank of the Middle America Trench in the Pacific Ocean offshore from Central America (Moore et al 1979, von Huene et al 1980, Aubouin et al 1982). Gas from these samples was mainly $C_{1}$ accompanied by minor amounts of the heavier hydrocarbon gases. The carbon isotopic composition of $\mathrm{C}_{1}$ from sediments recovered from the Black Sea (Hunt \& Whelan 1978) and from the Blake Outer Ridge (Claypool et al 1973, Galimov \& Kvenvolden 1983) range from $-63 \%$ o to $-94 \%$. These values fall in the range $(-50$ to $-90 \%$ o) that is generally considered to indicate biogenic $C_{1}$. Thus, the $C_{1}$ in marine gas hydrates in these two areas likely results from the bacterial alteration of organic matter buried in the sediment.

Preliminary unpublished results of measurements of the molecular and isotopic compositions of gas from a massive gas hydrate recovered in sediments at one site from the Middle America Trench (DSDP Leg 84) indicate a possible thermogenic source for $\mathrm{C}_{1}\left(\delta^{13} \mathrm{C}=-41 \%\right)$. However, this $\mathrm{C}_{1}$ occurs with extremely ${ }^{12} \mathrm{C}$-depleted $\mathrm{\Sigma CO}_{2}(+37 \%)$ and thus alternatively could be an unusual example of isotopically heavy biogenic $C_{1}$. Electric logging showed that the massive hydrate is about $3 \mathrm{~m}$ thick at a sediment depth of $250 \mathrm{~m}$. The gas hydrate at this site apparently made room for itself during the crystal-forming process, resulting in a massive gas hydrate containing minor quantities of sediment. 
Gas hydrates may act as a seal, trapping $C_{1}$ and other hydrocarbon gases beneath them (Hedberg 1980, Dillon et al 1980). If the interface between the base of the gas hydrate and the region of free gas intercepts porous and permeable beds, situations may be created where gas hydrates trap free gas in economically producible reservoirs. However, evidence for the widespread occurrence of such reservoirs associated with marine gas hydrates has not yet been clearly documented.

\section{CONCLUSIONS}

Hydrocarbon natural gas in oceanic sediment has multiple mechanisms of origin, although the most important one is $\mathrm{C}_{1}$ generation by microbiological decomposition of organic matter. Profiles of $\delta^{13} \mathrm{C}_{1}, \delta^{13} \mathrm{C}$ of $\Sigma \mathrm{CO}_{2}$, and $\mathrm{C}_{2} / \mathrm{C}_{1}$ ratios in the intermediate subbottom depth range $(50-1000 \mathrm{~m})$ indicate that microbiological $C_{1}$ generation is widespread in anoxic, sulfate-depleted ocean sediments. $C_{1}$ of thermogenic origin (along with $C_{2}$, etc) becomes a more important component of the gas mixture with increasing depth of burial. Thermogenic gas can be a major component locally where gas of a deeper, high-temperature $\left(>100^{\circ} \mathrm{C}\right)$ origin migrates to shallower marine sediments. In oxidizing marine sediments at relatively shallow depths $(<10 \mathrm{~m})$ beneath the seafloor, the small amounts and variable composition of hydrocarbon gas are determined by both generation and consumption processes.

Attempts to locate buried petroleum accumulations in marine sediments by detecting gas seeps on the seafloor must take into account the effects on gas composition of both the mechanisms of origin and near-surface alteration. Where hydrocarbon gas occurs in concentrations sufficient to saturate the interstitial water of marine sediment, either a free gas phase will form or the gas in excess of porewater solubility will form solid gas hydrate, depending on pressure and temperature. Gas hydrates composed largely of microbiological $C_{1}$ appear to be widespread in marine sediments near continental margins, but gas of deeper origin also may contribute to gas hydrate formation in some circumstances.

\section{ACKNOWLEDGMENT}

Critical comments and constructive suggestions by $\mathbf{R}$. S. Oremland and D. D. Rice significantly improved this review. D. R. Malone expertly processed the words. 


\section{Literature Cited}

Abram, J. W., Nedwell, D. B. 1978. Inhibition of methanogenesis by sulfate-reducing bacteria competing for transferred hydrogen. Arch. Microhiol. 117:89-92

Atkinson, L. P., Richards, F. A. 1967. The occurrences and distribution of methane in the marine environment. Deep-Sea Res. 14:673-84

Aubouin, J., von Huene, R., Baltuck, M. Arnott, R., Bourgois, J., et al. 1982. Leg 84 of the Deep Sea Drilling Project, Subduction without accretion: Middle America Trench off Guatemala. Nature 297:458-60

Barker, J. F., Fritz, P. 1981. Carbon isotope fractionation during microbiol methane oxidation. Nature 293:289-91

Barnes, R. O., Goldberg. E. D. 1976. Methane production and consumption in anoxic marine sediments. Geology $4: 297$ 300

Bernard, B. B. 1979. Methane in marine sediments. Deep-Sea Res. 26A: 429-43

Bernard, B. B., Brooks, J. M. Sackett, W. M. 1976. Natural gas seepage in the Gulf of Mexico. Earth Planet. Sci. Lett. 31:4854

Bernard, B. B., Brooks, J. M. Sackett, W. M. 1978. Light hydrocarbons in recent Texas continental shelf and slope sediments. $J$. Geophys. Res. 83: 4053-6i

Berner, R. A. 1980. Early Diagensis: A Theoretical Approach. Princeton, N.J.: Princeton Univ. Press. 241 pp.

Brooks, J. M. Frederick. A. D., Sackett, W. M., Swinnerton, J. W. 1973. Baseline concentrations of light hydrocarbons in Gulf of Mexico, Environ. Sci. Technol. 7:639-42

Brooks, J. M., Barnard, L. A., Wiesenberg. D. A., Kvenvolden, K. A. 1983. Molecular and isotopic compositions of gas in sediments at Site 533. In Initial Reports of the Deep Sea Drilling Project, R. E. Sheridan, F. Gradstein, a al, Vol. 76. Washington DC: USGPO. In press

Carlisle, C.T.. Bayliss, G.S. VanDelinder, D. G. 1975. Distribution of light hydrocarbons in seafloor sediments : correlation between Beochemistry, seismic structure, and possible reservoired oil and gas. 7th Offshore Technol. Conf., OTC 2341: 65-70

Claypool, G. E. 1974. Anuxic diayenesis and hacterial methane production in deep sea sediments. PhD thesis. Univ. Calif., Los Angeles. $276 \mathrm{pp}$.

Claypool, G. E. 1983. Organic geochemistry of carbon-deficient sediments, Leg 78A, DSDP. In Initial Reports of the Deep Sea Drilling Project, J. C. Moore, B. BijuDuval, et al, Vol. 78. Washington DC: USGPO. In press
Claypool, G. E., Kaplan, I. R. 1974. The origin and distribution of methane in marine sediment. In Natural Gases in Marine Sediments, ed. I. R. Kaplan, pp. 99 139. New York: Plenum. 324 pp.

Claypool, G. E., Threlkeld, C. N. 1983. Anoxic diagenesis and methane generation in sediments of the Blake Outer Ridge, DSDP Site 533, Leg 76. In Initial Reports of the Deep Sea Drilling Project, R. E. Sheridan, F. Gradstein, et al, Vol. 76. Washington DC: USGPO. In press

Claypool, G. E., Presley, B. J., Kaplan, I. R. 1973. Gas analyses in sediment samples from Legs 10, 11, 13, 14, 15, 18 and 19. In Initial Reports of the Deep Sea Drilling Project, J.S. Creager, D. W. Scholl, et al, 19:879-84. Washington DC: USGPO $913 \mathrm{pp}$.

Cline, J. D., Holmes, M. L. 1977. Submarine seepage of natural gas in Norton Sound. Alaska. Science 198:1149-53

Coleman, D. D. Risatti, J. B., Schoell, M 1981. Fractionation of carbon and hydrogen isotopes by methane-oxidizing bacteria. Geochim. Cosmochim. Acta 45: 103337

Culberson, O. L., McKetta, J. J. Jr. 1951. The solubility of methane in water at pressures to 10,000 psia. AlME Pet. Trans. 192: 223-26

Davis, J. B., Squires, R. M. 1954. Detection of microbially produced gaseous hydrocarbons other than methane. Science 119: 381-82

Dillon, W. P. Grow, J. A., Paull, C. K. 1980. Unconventional gas hydrate seals may trap gas off southeast U.S. Oil Gas $j$. $78(1): 124-30$

Doose, P. R., Kaplan, I. R. 1981. Biogenetic control of gases in marine sediments of Santa Barbara basin, California. Am. Assoc. Pet. Geol. Bull. 65:919-20 (Abstr.) Doose, P. R. Sandstrom, M. W., Jodele, R F., Kaplan, I. R. 1978. Interstitial gas analysis of sediment samples from Site 368 and Hole 369A. In Initial Reports of the Deep Sea Drilling Project, Y. Lancelot, E. Seibold, et al, $41: 861-63$. Washington DC: USGPO. 1259 pp.

Emery, K. O. Hoggan, D. 1958. Gases in marine sediments. Bull. Am. Assoc. Pet. Geol. 42: 2174-88

Erdman, J. G., Borst, R. L., Hines, W. J. 1969. Composition of gas sample I (cure 5) by components (1.5.1). In Initial Reports of the Deep Sea Drilling Project, M. Ewing. J. L. Worzel, et al, 1:461-63. Washington DC: USGPO. $672 \mathrm{pp}$

Frank, D. J., Gormly, J. R., Sackett, W. M. 1974. Revaluation of carbon-isotope com- 
position of natural methanes. Am. Assoc. Pet. Geol. Bull. 58:2319-25

Fuex, A. N. 1977. The use of stable isotopes in hydrocarbon exploration. J. Geochem. Explor. 7:155-88

Galimov, E. M., Kvenvolden, K. A. 1983. Concentrations and carbon isotopic compositions of $\mathrm{CH}_{4}$ and $\mathrm{CO}_{2}$ in gas from sediments of the Blake Outer Ridge, DSDP Leg 76. In Initial Reports of the Deep Sea Drilling Project, R. E. Sheridan, F. Gradstein, et al, Vol. 76. Washington DC: USGPO. In press

Galimov, E. M. Simoneit, B. 1982 Geochemistry of interstitial gases in sedimentary deposits of the Gulf of California. Deep Sea Drilling Project Leg 64. In Initia. Reports of the Deep Sea Drilling Project, J. R. Curray, D. G. Moore, et al, 64:781-87. Washington DC: USGPO. 1313 pp.

Galimov, E. M., Chinyanov, V. A., Ivanov, Ye. N. 1980. Isotopic composition of methane carbon and the relative content of Baseous hydrocarbons in the deposits of the Moroccan Basin of the Atlantic Ocean (Deep Sea Drilling Project Site 415 and 416). In Initial Reports of the Deep Sea Drilling Project, Y. Lancelot, E. L. Winterer, et al, 50:615-22. Washington DC: USGPO. 868 pp.

Gealy, E. L., Dubois, R. 1971. Shipboard geochemical analysis, Leg 7. Glomar Challenger. In Initial Reports of the Deep Sea Drilling Project, E. L. Winterer, W. R. Riedel, et al, 7:863-64. Washington DC USGPO. 1757 pp.

Gold, T. 1979. Terrestrial sources of carbon and earthquake outgassing. J. Pet. Geol. 1:3-19

Gold, T., Soter, S. 1980. The deep earth gas hypothesis. Sci. Am. 242(5): 154-61

Hampton, M. A., Kvenvolden, K. A. 1981. Geology and geochemistry of gas-charged. sediment on Kodiak Shelf, Alaska. GeoMar. Lett. 1: 141-47

Hand, J. H., Katz, D. L., Verma, V. K. 1974. Review of gas hydrates with implications for ocean sediments. In Natural Gases in Marine Sediments, ed. I. R. Kaplan, pp. 179-94. New York: Plenum. 324 pp.

Hedberg. H. D. 1980 . Methane generation and petroleum migration. In Problems of Petroleum Migration, ed. W. H. Roberts III, R. J. Cordell, pp. 179-206, Tulsa, Okla : Am. Assoc. Pet. Geol. 273 pp.

Hitchon, B. 1974. Occurrence of natural gas hydrates in sedimentary basins. In Natura Gases in Marine Sediments, od. I. R. Kaplan, pp. 195-225. New York: Plenum. 324 pp.

Hungate, R. E., Smith, W., Bauchop. T., Yu, I., Rabinowitz J. C. 1970. Formate as an intermediate in the bovine rumen fermen- tation. J. Bucteriol. 102:389-97

Hunt, J. M. 1974. Hydrocarbon geuchemistry of the Black Sea. In The Black SeaGeoloyy. ( Chemistry, and Bioloyy, ed. E. T. Degens, D. A. Ross, Mem. 20:499-504. Tulsa, Okla : Am. Assoc. Pet. Geol. 633 pp.

Hunt. J. M. 1975. Origin of gasoline range alkanes in the deep sea. Nature 254:41113

Hunt, J. M., Whelan, J. K. 1978. Dissolved gases in Black Sea sediments. In Initial Reports of the Deep Sea Drilling Project, D. A. Ross, Y. P. Neprochnov, et al. 42(2): 661-65. Washington DC: USGPO. 1244 pp.

Jannasch, A. W. 1975. Methane oxidation in Lake Kivu (central Africa). Limnol. Oceanogr. 20:860-64

Katz, D. L., Cornell, D., Kobayashi, R. Poettmann, F. H.. Vary. J. A., Elenblas, J. R., Weingug. C. F. 1959. Handbook of Natural Gas Engineering. New York: McGraw-Hill. 802 pp.

Kosiur, D. R., Warford, A. L. 1979. Methane production and oxidation in Santa Barbara basin sediments. Estuarine Coastal Mar. Res. 8: 379-85

Kristjansson, J. K., Schonheit, P.. Thauer, R K. 1982. Different Ks values for hydrogen of methanogenic bacteria and sulfatereducing bacteria: An explanation for the apparent inhibition of methanogenesis by sulfate. Arch. Microbiol. 131:278-82

Kvenvolden, K. A., Barnard, L. A. 1983a. Gas hydrates of the Blake Outer Ridge Site 533. DSDP/IPOD Leg 76. In Initial Reports of the Deep Sea Drilling Project, R. E. Sheridan, F. Gradstein, et al. Vol. 76. Washington DC: USGPO. In press

Kvenvolden, K. A. Bamard L. A. 1983 b. Hydrates of natural gas in continental margins. Proc. Hedberg Conf., Am. Assoc. Pet. Geol. Mem. 34. In press

Kvenvolden, K. A. McMenamin, M. A. 1980. Hydrates of natural gas: a review of their geologic occurrence. US Geol. Surv. Circ. 825. 11 pp.

Kvenvolden, K. A. Redden, G. D. 1980 Hydrocarbon gases in sediment of the shelf, slope, and basin of the Bering Sea. Geochim Cosmochim. Acta 44:1145-s0

Kvenvolden, K. A., Weliky, K. Nelson, C. H. DesMarais, D. J. 1979. Submarine seep of carbon dioxide in Norton Sound, Alaska. Science 205: 1264-66

Kvenvolden, K. A., Redden, G. D., Thor, D. R. Nelson, C. H. 1981 a. Hydrocarbon gases in near-surface sediment of the northern Bering Sea. In The Eustern Bering Sea Shelf: Oceanography and Resources, ed. D. W. Hood, J. A. Calder. 1:411-24, Seattle: Univ. Wash. Press. $625 \mathrm{pp}$. 
K venvolden, K. A., Vogel, T. M., Gardner, J. v. 1981b. Geochemical prospecting for hydrocarbons in the outer continental shelf, southern Bering Sea, Alaska. J. Geochem. Explor. 14:209-19

Lein, A. Yu., Namsaraev, B. B., Trotsyuk, V. Ya., Ivanov, M. V. 1981. Bacterial methanogenesis in Holocene sediments of the Baltic Sea. Geomicrobiol. J. 2:299-315

Lupton, J. E., Craig. H. 1981. A major Helium-3 source at $15^{\circ} \mathrm{S}$ on the East Pacific Rise. Science 214: 13-18

Lyon, G. L. 1973. Interstitial water studies, Leg 15, chemical and isotopic composition of gases from Cariaco Trench sediments. In Initial Reports of the Deep Sea Drilling Project, B. C. Heezen, I. D. MacGregor, et al. 20:773-74. Washington DC: USGPO. $958 \mathrm{pp}$.

Mah, R.A.,Ward, D. M., Baresi, L., Glass, T. L. 1977. Biogenesis of methane. Ann. Rev. Microbiol. 31 : 309-41

Martens, C. S., Berner, R. A. 1974. Methane production in the interstitial waters of sulfate-depleted marine sediments. Science 185: 1167-69

Martens, C. S., Berner, R. A. 1977. Interstitial water chemistry of anoxic Long Island Sound sediments. I. Dissolved gases. Limnol. Oceanogr. 22: 10-25

Mclver, R. D. 1973. Appendix III. Hydrocarbon gases from canned core samples, sites 174A, 176, and 180. In Initial Reports of the Deep Sea Drilling Project, L. D. Kulm, R. von Huene, et al, 18:1013-14. Washington DC: USGPO. 1077 pp.

Mclver, R. D. 1975. Hydrocarbon occurrences from JOIDES Deep Sea Drilling Project. Proc. World Pet. Cong., 9th, 2:269-80. London: Applied Sci. Publ. 376 $\mathrm{pp}$.

McKenna, E. J., Kallio, R. E 1965 . The biology of hydrocarbons Ann. Rev. Microbiol. 19: 183-208

Moore, J. C. Watkins, J. S., et al. 1979. Middle American Trench. Geotimes 24(9): 20-22

Morris, D. A. 1976. Organic diagenesis of Miocene sediments from Site 341, Vering Plateau, Norway. In Initial Reports of the Deep Sea Drilling Project, M. Talwani, G. Udintsev, et al, 38:809-14. Washington DC: USǴPO. $1256 \mathrm{pp}$

Mountfort, D. O., Asher, R. A. 1978. Changes in proportions of acetate and carbon dioxide used as methane precursors during the anaerobic digestion of bovine waste. Appl. Environ. Microhiol. 35:648-54

Mountfort, D. O., Asher, R. A. Mays, E. L. Tiedje, J. M. 1980. Carbon and electron flow in mud and sandflat intertidal sediments at Deleware Inlet. Nelson, New
Zealand. Appt. Einviron. Micrubiol. $39: 686-94$

Nikaido, M. 1977. On the relation between methane production and sulfate reduction in bottom muds containing sea water sulfate. Geochem. J. 11: 199-206

Nissenbaum, A., Presley, B. J., Kaplan, I. R 1972. Early diagenesis in a reducing fjord Saanich Inlet, British Columbia-I. Chemical and isotopic changes in major components of interstitial water. Geochim. Cosmochim. Acta 36: 1007-27

Oremland, R. S. 1981. Microbial formation of ethane in anoxic estuarine sediments. Applied Environ. Microbiol. 42: 122-29

Oremland, R. S., Taylor, B. F. 1978. Sulfate reduction and methanogenesis in marine sediments. Geochim. Cosmuchim. Acto 42:209-14

Oremland, R. S., Marsh, L., DesMarais, D. J. 1982a. Methanogenesis in Big Soda Lake, Nevada: an alkane, moderately hypersaline desert lake. Appl. Environ. Microbiol. 43: 462-68

Oremland, R. S., Marsh, L. M., Polcin, S. 1982b. Methane production and simultaneous sulfate reduction in anoxic, salt marsh sediments. Nature $296: 143-45$

Patt, T. E., Cole, G. C., Bland, J., Hanson, R. S. 1974. Isolation and characterization of bacteria that grow on methane and organic compounds as sole source of carbon and energy. J. Bacteriol. 120:955-64

Primrose, S. B., Dilworth, M. J. 1976. Ethylene production by bacteria. J. Gen. Microbiol. 93: 177-81

Rashid, M. A., Vilks, G., Leonard, J. D. 1975. Geological environment of a methane-rich recent sedimentary basin in the Gulf of St. Lawrence. Chem. Geol. 15: 83-96

Reeburgh, W. S. 1969. Observations of gases in Chesapeake Bay sediments. Limnol. Oceanogr. 14:368-75

Reeburgh, W. S. 1976. Methane consumption in Cariaco Trench waters and sediments. Earth Planet. Sci. Lett. $28: 337-44$

Reeburgh, W. S. 1980 . Anaerobic methane oxidation: rate depth distributions in Skan Bay sediments. Earth Planet. Sci. Lett. 47: 345-52

Reeburgh, W. S., Heggie, D. T. 1977. Microbial methane consumption reactions and their effect on methane distributions in freshwater and marine environments. Limnol. Oceanogr. 22: 1-9

Reed, W. E. Kaplan, I. R. 1977. The chemistry of marine petroleum soeps. J. Geochem. Explor. 7:255-93

Reitsema, R. H. Lindberg, F. A., Kaltenback, A. J. 1978. Light hydrocarbons in Gulf of Mexico water: sources and relation to structural highs. J. Geochem. Explor. 10: |39-5| 
Revelle. R. 19S0. Sexlimentation and weanography: survey of field observations. Geol. Soc. Am. Mem. 43, pt. 5.6 pp.

Rice. D. D., Claypuol. G. E. 1981. Generation, accumulation. and resuurce potential of biogenic gas. Am. Assoc. Pet. Geol. Bull. 65: 5-25

Rosenfeld, W. D., Silverman, S. R. 1959 Carbon isotopic fractionation in bacterial production of methane. Science 130: 165859

Rudd. J. W. M. 1980. Methane oxidation in Lake Tanganyika (East Africa). Limnol. Oceanoyr. 25: $958-63$

Rudd, J. W. M. Hamilton. R. D. 1975 Factors controlling rates of methane oxidation and the distribution of the methane oxidizers in a small stratified lake. Arch. H jdrobiol. 75: 522-38

Rudd. J. W. M., Hamilton, R. D. 1978 Methane cycling in a eutrophic shield lake and its effects on whole lake metabolism. Limnol. Oceanoyr. $23: 337-48$

Rudd. J. W. M., Hamilton. R. D., Camphell, N. E. R. 1974. Measurement of microbia oxidation of methane in lake water. Limnol. Oceanoyr. 19:519-24

Sackett. W. M. 1977. Use of hydrocarbon sniffing in offshore exploration. $J$. Geochem. Explor. 7:243-54

Sansone, F. J., Martens, C. S. 1981. Methane production from acetate and associated methane fluxes from anoxic coastal sediments. Science 211:707-9

Sheridan, R. E., Gradstein, F., et al. 1982 Early history of the Atlantic Ocean and gas hydrates in the Blake Outer Ridge: Results of the Deep Sea Drilling Project Leg 76. Geol. Soc. Am. Bull. 93: 876-85

Shipley, T. H., Houston, M. H., Buffier, R. T. Shaub, F. J. McMillan, K. J., Ladd, J. W. Worzel, J. L. 1979. Seismic evidence for widespread possible gas hydrate horizons on continental slopes and rises. Am. Assoc. Pet. Geol. Bull. 63:2204-13

Sigalove, J. J., Pearlman, M. D. 1975. Geochemical seep detection for offshure oil and gas exploration. 7th Offshore Technol. Conf., OTC 2344: 95-102

Silverman, M. P., Oyama, V. I. 1968 Automatic apparatus for sampling and preparing gases for mass spectral analysis in studies of carbon isotope fractionation during methane metabolism. Anal. Chem. 40: 1833-37

Simuneit, B., Lonsdale, P. 1982. Hydrothermal petroleum in mineralized mounds at the sea bed of Guaymas Basin, Gulf of California. Nuture 295: 198-202

Serensen, J., Christensen, D., Jergensen, B. B. 1981. Volatile falty acids and hydrogen as substrates for sulfate-reducing bacteria in anaerobic marine sediment. Appl. Environ.
Microhiul. 42:5-11

Swinnerton. J. W.. Lamontagne, R. A. 1974. Oceanic distribution of low-molecularweight hydrocarbons Baseline measurements. Environ. Sci. Technel. 8: 657-63

Vogel. T. M., Oremland, R. S., Kvenvolden. K. A. 1982. Low-temperature formation of hydrocarbon gases in San Francisco Bay sediment. Chem. Gewl. 37: 289-98

von Huene, R., Aubouin, J., Azema, J. Blackinton, G., Carter, J. A. et al. 1980. Leg 67- the Deep Sea Drilling Project Mid-America Trench Iransect of Guatemala. Geol. Soc. Am. Bull. 91:42132

Warford, A. L., Kosiur, D. R., Doose, P. R. 1979. Methane production in Santa Barbara Basin sediments. Geumicrohiol. J. $1: 117 \cdot 37$

Welhan, J. A. 1980. Gas concentrations and isotope ratios at the $21^{\circ} \mathrm{N}$ EPR hydrothermal site. EOS. Trans. Am. Geophys. Union 61: 996 (Abstr.)

Welhan. J. A., Craig, H. 1979. Methane and hydrogen in East Pacific Rise hydrothermal fluids. Geophys. Res. Lett. 6:82931

Whelan. J. K. 1979. $C_{1}-C_{\text {, hydrocarbons }}$ from IPOD Holes 397 and 397A. In Initial Reports of the Deep Sea Drilliny Project. U. von Rad, W. B. F. Ryan, et al, $47(1)$ : 531 39. Washington DC: USGPO. $835 \mathrm{pp}$

Whelan, J. K., Hunt, J. M. 1979a. C, to C, hydrocarbons from IPOD Hole 398D. In Initial Reports of the Deep Sea Drilliny Project, J.-C. Sibuet, W. B. F. Ryan, et al. 47(2): 561-63. Washington DC: USGPO. $787 \mathrm{pp}$.

Whelan, J. K., Hunt, J. M. 1979b. Sediment $C_{1}-C$, hydrucarbons from IPOD Leg 48- Bay of Biscay. In Initial Reports of the Deep Sea Drilling Project, L. Montadert, D. G. Roberts, et al, 48:943-45, Washington DC: USGPO. $1183 \mathrm{pp}$

Whelan, J. K., Hunt, J. M. 1980a. Sediment $C_{1}-C$, hydrocarbons from Deep Sea Drilling Project sites 415 and 416 (Moroccan Basin). In Initial Reports of the Deep Sea Drilling Project, Y. Lancelot, E. L. Winterer, et al, 50:623-24. Washington DC: USGPO. $868 \mathrm{pp}$.

Whelan, J. K., Hunt, J. M. 1980b. C, -C, volatile organic compounds in sediments from Deep Sea Drilling Project Legs 56 and 57. Japan Trench. In Initial Reports of the Deep Sea Drilling Project, Scientific Party. 56-57:1349-65. Washington DC: USGPO. 1417 pp.

Whelan, J. K., Hunt, J. M. 1981. C, $-C_{\text {e }}$ hydrocarbons in IPOD Leg 63 sediments from vuter California and Baja California Borderlands. In Initial Reports of the Deep Sea Drilling Project, R. S. Yeats, B. U. Haq. 
et al, 63:775 84. Washington DC: USGPO. $967 \mathrm{pp}$.

Whelan, J. K.. Sato, S. $1980 . C_{1}-$ C, hydrocurbons from core gas pockets, Deep Sea Drilling Project Legs 56 and 57, Japan Trench Transect. In Initial Reports of the Deep Sea Drilling Project, Scientific Party. 56-57: 1335-47. Washington DC: USGPO. $1417 \mathrm{pp}$

Whelan, J. K., Hunt, J. M., Berman, J. 1980. Volatile $C_{1}-C_{7}$ organic compounds in surface sediments from Walvis Bay. Geochim. Cosmochim. Acta 44:1767-85

Winfrey, M. R., Zeikus, J. G. 1977. Effect of sulfate on carbon and electron flow during microbial methanogenesis in freshwater sediments. Appl. Environ. Microbiol. $33: 275-81$
Winfrey, M. R., Danıelle, (;. M., Bianchı, A. J. M.. Ward, D. M. 1981. Vertical distribution of sulfate reduction, methane production, and bacteria in marine sediments. Geomicrohiol. J. 2:341-62

Yefremova, A. G. Zhizhchenko, B. P. 1975. Occurrence of crystal hydrates of gases in the sediments of modern marine basins. Dokl. Acad. Sci. USSR Earth Sci. Sect. 214:219-20

Zeikus, J. G. 1977. The biology of methanogenic bacteria. Bacteriol. Rev. 41:51441

Zinder, S. H., Brock, T. D. 1978. Production of methane and carbon dioxide from methane thiol and dimethyl sulfide by anaerobic lake sediments. Nature 273:226-28 
APPENDIX D

Hydrates of Natural Gas:

A Review of Their Geologic Occurrence

By Keith A. Kvenvolden and Mark A. McMenamin

GEOLOGICAL SURVEY CIRCULAR 825 
United States Department of the Interior

\section{CECIL D. ANDRUS, Secretary}

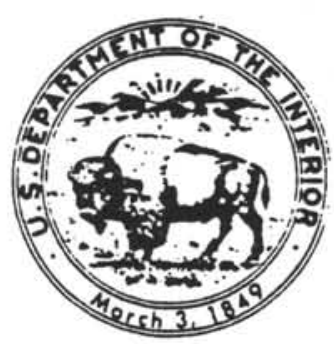

Geological Survey

H. William Menard, Director 


\section{CONTENTS}

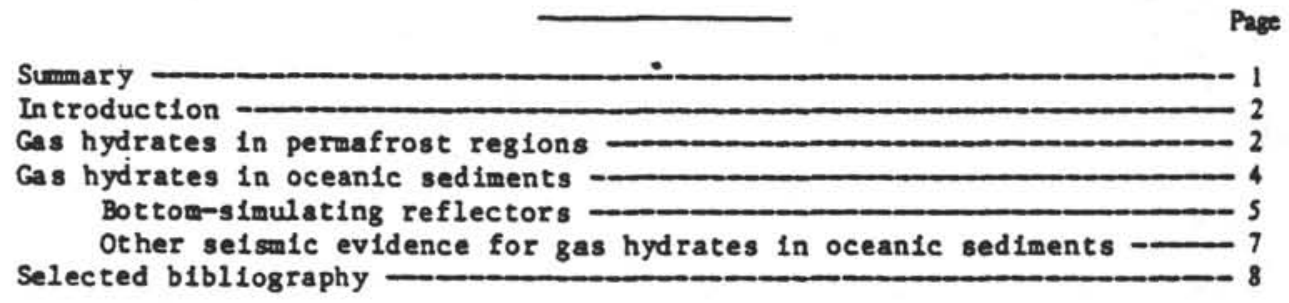

\section{IILUSTRATIONS}

Figure 1. Phase boundary diagram showing free methane gas and methane hydrate -

2. Map showing location of known and inferred occurrences of gas hydrates in permafrost reglons and in oceanic sediment - 3

3. Graph of gas hydrate zone shown as intersection of geothermal gradient with hydrate-gas phase boundary

4. Diagram showing idealized section of methane gas hydrate zone in sediments of outer continental margins

5. Diagrammatic seismic profile of Blake-Bahama Outer Ridge showing bottow-simulating reflector - 6

\section{TABLES}

Table 1. Geologic, geophysical, and geochemical evidence for gas hydrates beneath permafrost

2. Geologic, geophysical, and geochemical evidence for gas hydrates in the seafloor 


\title{
Hydrates of Natural Gas:
}

\section{A Review of Their Geologic Occurrence}

\author{
By Keith A. Kvenvolden and Mark A. McMenamin'
}

\section{SUMMARY}

Gas hydrates are a type of inclusion compound or clathrate formed as 1celike mixtures of gas and water in which gas molecules are trapped within a framework or cage of water molecules. Large quantities of natural gas (mainly methane) can be trapped in sediments in the form of gas hydrates. The pressure and temperature cond1tions for the formation of gas hydrates are found in regions of permafrost and beneath the sea in outer continental margins and ocean basins. In addition to suitable temperature and pressure conditions, sufficient concentrations of methane must be present for hydrate stability. This methane may be produced in sediments by blologIcal processes; however, the extent of this production is not fully understood. Methane could also migrate from thermochemically altered organic matter at depth.

The presence of gas hydrates in permafrost regions has been established at the Messoyakha gas field in western Siberia, in two exploratory wells in the Mackenzle Delta area of Canada, and in a wildcat well on the North Slope of Alaska. In the Alaskan well, a pressure core barrel successfully recovered gas hydrate in sediment at in situ temperature and pressure. Although gas hydrates have now been 1dentified in permafrost areas, the geographical extent of these hydrates has not yet been determined.

Geologic, geochemical, and geophysical ev1dence suggests that gas hydrates can exist in any areas beneath the seafloor. Geologic evidence consists of (1) widespread areas where pressures and temperatures are suitable for gashydrate stability and (2) recovery of deep-sea sediment cores that release gas and cool endothernically when exposed to sea-level temperature and pressure. Geochemical observations include (1) high concentrations of methane in sediment,

'Present addrexx Deperment of Geological Sciences, University of Califormin, Senta Barbera, CA 93106 usually accompanied by low concentrations of ethane, and (2) gas released from thawing cores in the volumes expected for the decomposition of gas hydrate. Geophysical evidence Includes (1) seismic anomalies that can be explained by the properties of sediments containing hydrates, (2) high acoustic velocity in sediments from suspected hydrate zones, and (3) laboratory experiments which show that the acoustic velocities of sediment increase when gas hydrate is formed in the sediment.

The main selsmic evidense for submarine gas hydrates are reflectors that simulate the topography of the seafloor. Such reflectors appear on seismic records from the east coast of North America, the North Pacific, the Bering Sea, and the Pacific and Atlantic coasts of Central Amer1ca. They l1e anywhere from 100 to 1,100 meters below the bottom. Bottow-simulating reflectors have been seen only in water deeper than $400 \mathrm{~m}$ and are generally manifest on seismic records as a reflection polarity reversal caused by an abrupt decrease in selsmic velocity. The exact relations of bottom-simulating reflectors to gas hydrate zones are uncertaln. The change in seismic Impedance may mark the bottom of the gashydrate zone where free methane gas is trapped beneath the hydrate layer. Other features on seismic records that may indlcate the presence of hydrates are bottow-paralleling bright spots, pagoda structures, and deep-water velocity amplitude features (VAMP's).

Not all bottom-simulating reflectors may be directly related to gas hydrates. For example, a bottom-simulating reflector lacking polarity reversal in sediments of the Bering Sea is currentiy thought to represent a migrating diagenetic boundary related to the dissolution of diatoms and the induration of claystone.

If large quantities of gas hydrate are widespread in permafrost reglons and in offshore marine sediments, they may be potential energy resources. The gas within the hydrate itself may 
not be recoverable, but the free gas trapped beneath it may be the important resource.

\section{INTRODUCTION}

Gas hydrates are a special kind of clathrate formed from a mixture of natural gas and water. Clathrates are inclusion compounds in which two or more chemical compounds form a stable crystalline mixture. One constituent forms the clathrate framework, a molecular lattice with an ordered geometric pattern. The other constituents of the clathrate fill the sites or cages within the framework structure. A clathrate framework, because it may contain many vacant sites, is a nonstoichiometric substance (a substance that cannot be accurately described by a single chemical formula). Water, because of its hydrogenbonding properties, is an excellent clathrate framework compound. An expanded ice lattice forms cages that can contain gas molecules such as argon, methane, propane, isobutane, sulfur dioxide, carbon dioxide, and hydrogen sulfide.

The term "gas hydrate" is used here to mean a water-methane clathrate that may or may not contain ethane, propane, and other hydrocarbons. Under suitable pressures, natural gas, which contains mainly methane, can interact with water to fort a solid 1cellke mixture, that is, a gas hydrate, at temperatures considerably above the freezing point of water (fig. 1). The amount of methane needed for hydrate formation depends on temperature and pressure. In the methane-water system, only methane present in excess of the amount soluble in water is avallable for hydrate formation. In an 1deally saturated hydrate, with all cages filled by methane molecules, the molar ratio of methane to water can be nearly 1:6. The formula for an ideal stoichiometric methane-water clathrate is $\mathrm{CH}_{4}{ }^{5} 5-3 / 4 \mathrm{H}_{2} \mathrm{O}$. One cublc meter of this ideal hydrate would contain the equivalent of about 170 cubic meters of free methane gas. Gas hydrates found in nature contain less gas than this because the lattice cages are not completely filled. Nevertheless, gas hydrates in reservo1r rocks can contain much more methane per unit volume than could be contained as free gas In the same space. This fact suggests that if gas hydrates exist in large quantities in the upper few hundred meters of the earth's crust, they would constitute a significant potential energy resource. Also, because gas hydrates are impermeable to free gas, a layer of hydrate could trap economically important quantities of free gas below $1 \mathrm{t}$.

Petroleum exploration drilling in Arctic reglons has established the occurrence of $\mathrm{gas}$ hydrate below permafrost (f1g. 2). Marine se1smic studies and Deep Sea Drilling Project cores strongly indicate the presence of gas hydrates in some seafloor sediments (f1g. 2). This paper reviews what $18 \mathrm{known}$ about these naturally occurring gas hydrates.

\section{GAS HYDRATES IN PERMAFROST REGIONS}

The fact that temperature and pressure conditions beneath permafrost regions fall within the stability field of gas hydrates ( $f 1 g .3$ ) was recognized in the 1940's. Now several deposits of gas hydrate are known (table 1). In 1970, well logging and formation tests in the Messoyakha gas field in western Siberia revealed billions of cubic meters of methane gas frozen as gas hydrate (Makogon and others, 1971, 1972; both

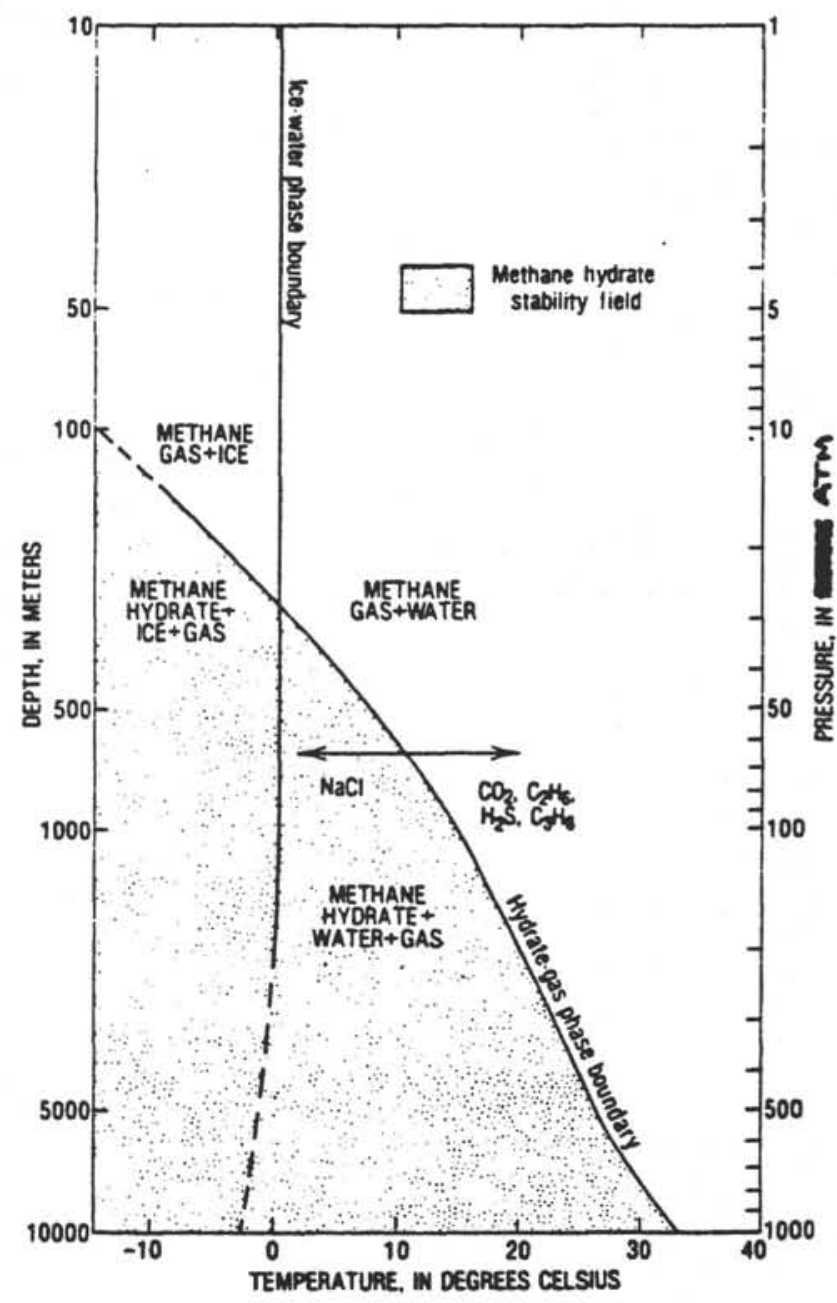

F1gure 1-Phase boundary diagram showing free methane gas and methane hydrate (pattern) for a fresh water-pure methane system. Addition of $\mathrm{NaCl}$ to water lowers temperature of hydrate formation, in effect shifting gas-hydrate curve to left. Addition of $\mathrm{CO}_{2}, \mathrm{~B}_{2} \mathrm{~S}, \mathrm{C}_{2} \mathrm{~B}_{6}$, or $\mathrm{C}_{3} \mathrm{H}_{8}$ ralses temperature of hydrate formation, in effect shifting curve to right. Therefore, 1mpurities in natural gas w1ll increase area of hydrate stability field. Depth scale is an approximation assuming that 11thostatic and hydrostatic pressure gradients are both 0.1 atmosphere per meter $(10.1 \mathrm{kPa} / \mathrm{m})$, but the true 11thostatic gradient is slightly greater. Redrawn after Katz and others (1959). 


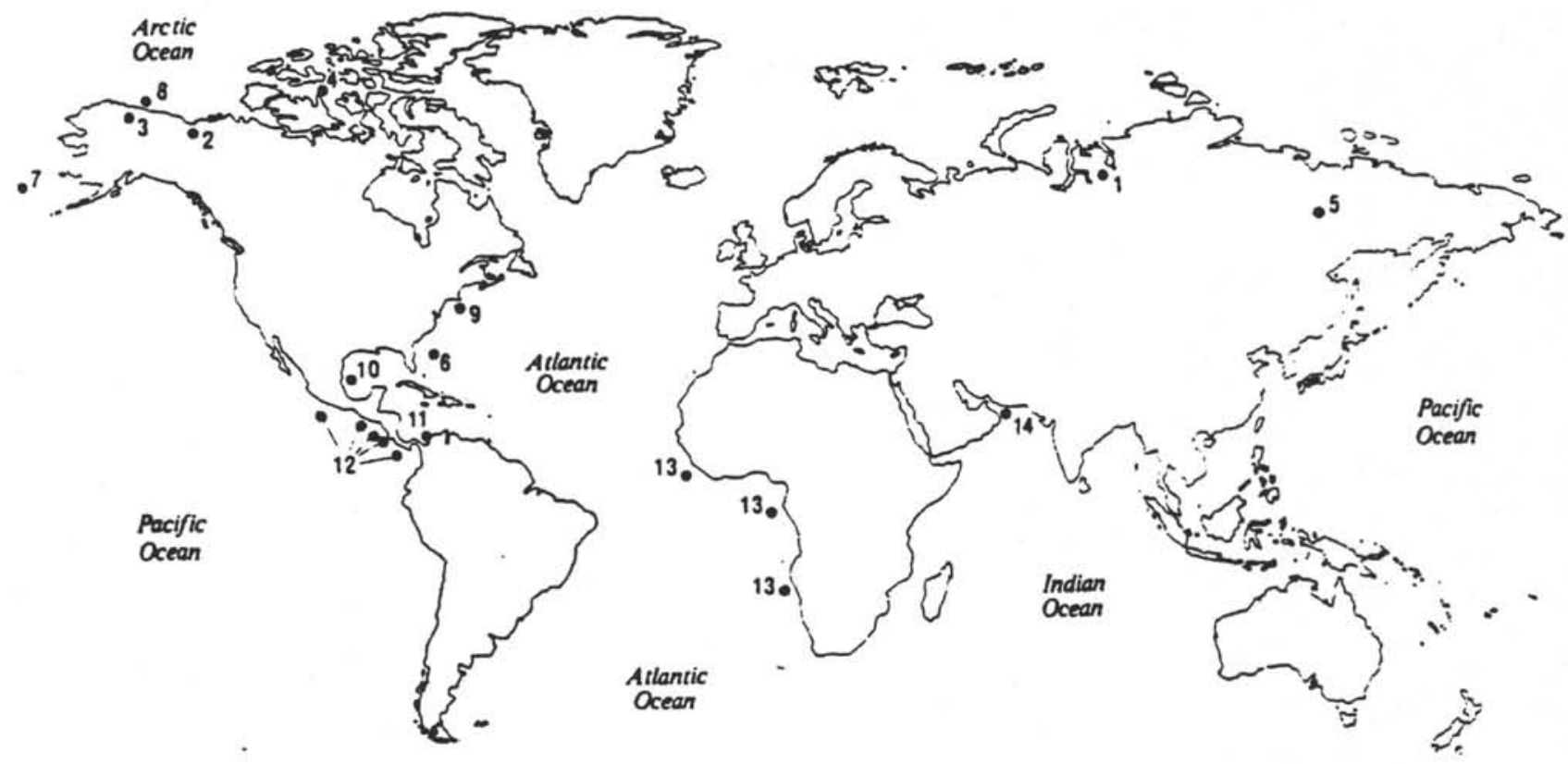

F1gure 2.- Known and Inferred accumulations of gas hydrate. Dots on land depict suspected or confirmed occurrences of gas hydrates beneath permafrost. Dots in oceans show areas where seismic or drilling evidence suggests presence of gas hydrates. See tables 1 and 2 for a 11 sting of each site, along with geologic, geophysical, and geochemical evidence for hydrate presence, research organization involved, and pertinent references.

references cited by Milton, 1976). Methane was released from the gas hydrate by injecting methanol into test wells that perforated the hydrate zone. The injections of methanol, which serves as a hydrate inhibitor, resulted in a large increase in $g$ as productivity from the test wells. The parts of the Messoyakha fleld containing gas hydrates are calculated to have 54 percent more reserves than would be expected in an equal volume of reservoir rocks filled with free gas.

Two exploratory wells drilled in permafrost of the Mackenzie Delta penetrated shallow sand reservolrs contalning gas hydrate at depths of 820 to 1,100 a (B1ly and D1ck, 1974). The amoun of formation gas in the drilling mud increased significantly during penetration of these sands. Although these sands were very porous, their permeability was extremely low. Low permeability and pronounced gas release are characteristic of hydrate-filled reservolrs. The low permeability is thought to result from the plugging of sed1ment interstices by gas hydrate, and the gas $11 \mathrm{~b}-$ erated is attributed to hydrate decomposition. other characteristics of the gas hydrate zone are visible on well logs (B1ly and Dick, 1974). The hydrace-bearing sands have a relatively high resistivity. Spontaneous potential (SP) curves show very little deflection in hydrate zones in comparison with deflections in free-gas and free-water zones. Sonic logs show

Table 1. Evidence for gat hydrates beneath pernafroest

\begin{tabular}{|c|c|c|c|c|c|c|c|}
\hline $\begin{array}{c}\text { mor } \\
\text { oner } \\
\text { on } \\
\text { tig. } \\
\end{array}$ & Lecetion & 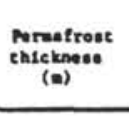 & $\begin{array}{l}\text { redicted } \\
\text { depeh range } \\
\text { of hydrace } \\
\text { (a) }\end{array}$ & $\begin{array}{l}\text { Coophyoleal } \\
\text { evidence }\end{array}$ & $\begin{array}{l}\text { Coochenical } \\
\text { ovidenco }\end{array}$ & $\begin{array}{l}\text { Rasearch } \\
\text { organal zation }\end{array}$ & Meferencen \\
\hline 1 & 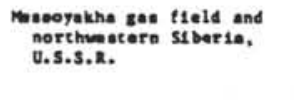 & 450 & $-250-870-$ & & 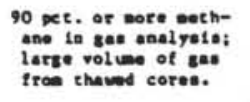 & 一 0.5.s.2. & $\begin{array}{l}\text { Mekogon and } \\
\text { others. } 1971 .\end{array}$ \\
\hline 2 & $\begin{array}{l}\text { Meckenzie Dolta, Northuest } \\
\text { Torriteories, Canoda }\end{array}$ & 610 & $-820-1100$ & 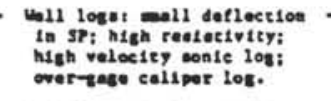 & - $0 .-$ & $\begin{array}{l}\text { teperial ofl. } \\
\text { Ld. }\end{array}$ & $\begin{array}{l}\text { s11y and rek, } \\
1974 .\end{array}$ \\
\hline 3 & 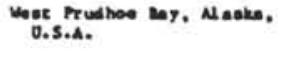 & 610 & $-210-1100$ & 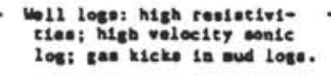 & -10. & -Exoen- & $\begin{array}{l}\text { A. D. Ne iver, } \\
\text { veitten comina., } \\
\text { !979. }\end{array}$ \\
\hline 4 & $\begin{array}{l}\text { Aret le Arehipolago, North- } \\
\text { weat Territortes, Canade }\end{array}$ & 530 & $\begin{array}{l}\text { No daca } \\
\text { is priat. }\end{array}$ & - & - Ho date to print - & $\begin{array}{l}\text { Dowe Netrolecun, } \\
\text { Led. }\end{array}$ & wetcheon, : 976. \\
\hline s & $\begin{array}{l}\text { vilyuy laeia, takutia, } \\
\text { v.s.s.2. }\end{array}$ & 2300 & - & 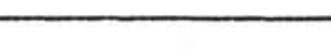 & do. & -0.3 .5 .2$. & $\begin{array}{l}\text { Nakozon and } \\
\text { others, } 1972 .\end{array}$ \\
\hline
\end{tabular}


an increase in acoustic velocity, and the callper log indicates over-gage borehole through many hydrate-bearing zones.

The first conclusive confirmation that $\mathrm{gas}$ hydrates occur in sediments under permafrost was obtained from pressure core barrel samples at the Arco-Exxon N.W. Elleen State No. 2 wildcat well on the north slope of Alaska in the West Prudhoe Bay field (R.D. McIver, written commun., 1979). Two pressurized cores were successfully recovered and were maintained in the barrel at temperatures slightly above $0^{\circ} \mathrm{C}$. At the time the cores were collected it was uncertain whether the cores had contained gas hydrate or only pressurized free methane. If the cores had contained free gas at in situ temperature and pressure, the pressure in

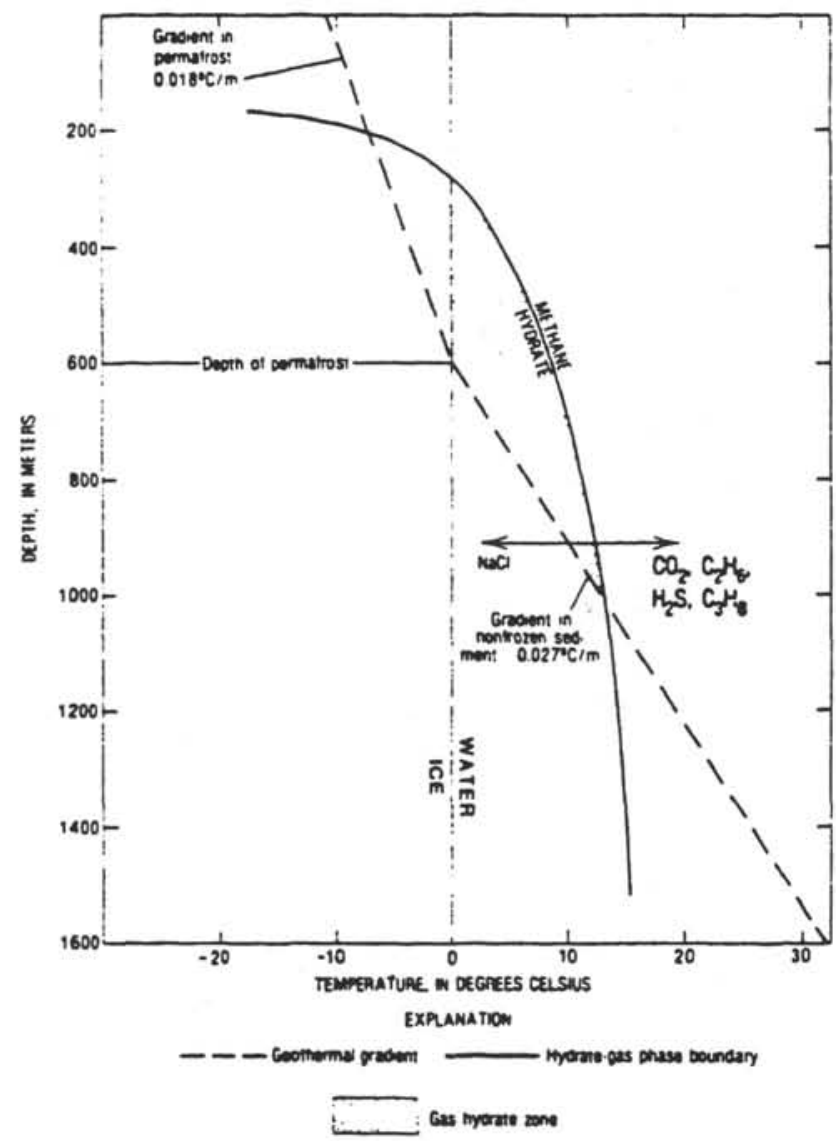

F1gure 3.--Gas hydrate zone, shown as area between intersections of geothermal gradient with hydrate-gas phase boundary curve. Within this area, pressure and temperature conditions are favorable for hydrate formation. Plot shows pure methane hydrate zone for an Arctic region in which permafrost is 600 m thick and enough methane is present to form hydrate. Pressure gradient $1 \mathrm{~s} 0.1 \mathrm{~atm} / \mathrm{m}(10.1 \mathrm{kPa} / \mathrm{m})$. Geothermal gradient changes at base of permafrost. Changes in gas composition or water salinity will shift phase boundary curve in same sense as figure 1. Redrawn after B1ly and Dick (1974). the barrel would have been expected to decrease linearly as gas was withdrawn from the barrel. However, pressure was maintained even after repeated samples were withdrawn. This result could only have been caused by the decomposition of hydrate after each increment of pressure release and gas removal. Immediately after each sample was removed and the system closed, pressure began to build toward the pressure of hydrate equilibrium. The sampled gas was 93 percent methane and 7 percent nitrogen.

Well logs in the Eileen well also indicated the hydrate zone. Whereas strong mud-gas shows suggested free gas in the formation, the high resistivities and high velocities on the sonic 108 indicated ice or icelike materials. The density log also responded as if there were ice rather than gas in the formation. In combination the resistivity, sonic, and mud logs pointed to the presence of hydrates.

In addition to the North Slope, the Mackenzie Delta, and the western Siberian basin, the Arctic Archipelago of Canada and the vilyuy basin of the U.S.S.R. show evidence of gas hydrate deposits. Gas-flow data from a well in Winter Harbor in the Arctic Archipelago suggested the presence of gas hydrates (Hitchon, 1974). Makogon and others (1972) repozted that the Central Vilyuy gas field in Yakutia, U.S.S.R., contains gas hydrates beneath permafrost.

Any sedimentary basin with extensive areas of relatively thick (several hundred meters) continuous permafrost may contain potentially commercial occurrences of gas hydrates. Antarctica may have large gas hydrate accumulations, although few data on Antarctic permafrost areas are ava1lable (Hitchon, 1974). No drilling program has been conducted on the Antarctic continent except for a few experimental holes, but the land temperature profile is such that gas hydrates could exist at depths of,more than $1,800 \mathrm{~m}$.

\section{GAS HYDRATES IN OCEANIC SEDIMENTS}

Pressure and temperature conditions in the deep sea floor are within the range of gas hydrate stability (fig. 4), and the possible presence of gas hydrates has been noted in several areas (table 2). Observation of deep-sea sediment cores that release large quantities of methane suggest that gas hydrates exist in some areas beneath the seafloor. In reviews of sediment gas data from the Deep Sea Drilling Project (DSDP), Claypool and others (1973; Legs 10-19) and McIver (1974; Legs 18-23) described instances where gas evolved from core samples after they were taken on deck. Cas evolution sometimes continued for several hours, and the pressures generated were occasionally sufficlent to extrude cores from the barrel and rupture sealed containers. The expanding, cooling gas formed ice on the exposed cores. The quantity and rate of gas evolution could indicate the decomposition of $\mathrm{gas}$ hydrate, although high concentrations of gas not in hydrated form can produce similar results. In most instances, the gas was methane with traces 
of ethane. Recent results from DSDP Legs 66 and 67 provide more evidence for the presence of gas hydrates in sediments on the slope of the M1dAmerica Trench off Central America (Geotimes, $1979 \mathrm{a}, 1979 \mathrm{~b})$. On both of these legs, gas-releasing cores were observed. Frozen sediment was recovered frow the zone of hydrate stability at Sites 490,491,492, 497, and 498. Gas expansion volumes as high as 50 to 1 ( $R$. von Huene, oral commun., 1979) suggest that gas hydrates had Indeed been sampled.

Methane in ocean sediment may be of either biochemical or thermal origin. It is uncertain, however, that enough gas to support the formation of gas hydrate can be generated by methane-producing bacterla alone. Claypool and Raplan (1974) estimated that blological generation of methane in sediment containing 0.5 percent organic carbon near sediment depths of around 1,000 m (corresponding to $30^{\circ} \mathrm{C}$ ) is $20 \mathrm{mmol}$ per kilogram of interstitial water. They also estimated the threshold methane concentration for hydrate stability as $58 \mathrm{~mol} / \mathrm{kg}$. Thermocatalytic methane is produced by alteration of organic matter at temperatures greater than $50^{\circ} \mathrm{C}$, but gas hydrates are stable only at relatively low temperatures. For gas hydrates to form from themocatalytic natural gas (methane), such gas must migrate upward from burlal depths greater than $1,500 \mathrm{~m}$ into cooler regions where it could be incorporated into a gas hydrate zone.

\section{BOTTOMSIMULATING REFLECTORS}

A bottow-simulating reflector is an anomalous seismic reflector that parallels the topography of the seafloor but lies anywhere from 100 to $1,100 \mathrm{~m}$ below the bottom. Bottom-simulating reflectors are most easily recognized on seisuic records when they cut across other reflectors and occur in water depths greater than $400 \mathrm{~m}$. They

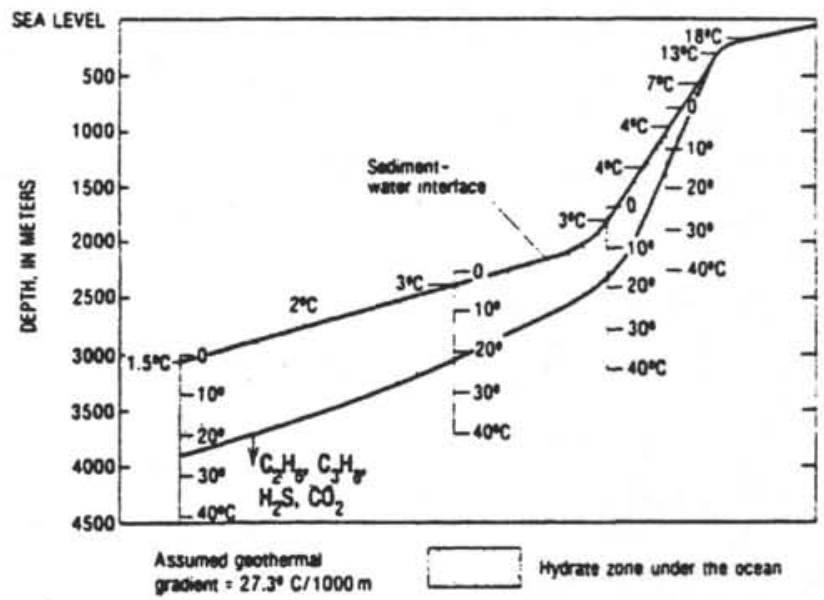

Figure 4.--Idealized section of gas hydrate zone in sediments of outer continental margins, computed for pure methane. Stippled zone is potential area of hydrate formation, where pressure and temperature conditions are correct for hydrate stability assuming an adequate supply of methane. Presence of other gases in methane would increase methane hydrate envelope downward. Increasing pressure from height of water column causes increase in subbottom depth of gas hydrate zone. Decreasing sediment temperature (down to $1^{\circ} \mathrm{C}$ in coldest, deepest bottom waters) also icreases hydrate subbottom depth. Redrawn from R.D. McIver, written commun., 1979.

Dable 2. - zoldence for tue bydraces to the seefloor

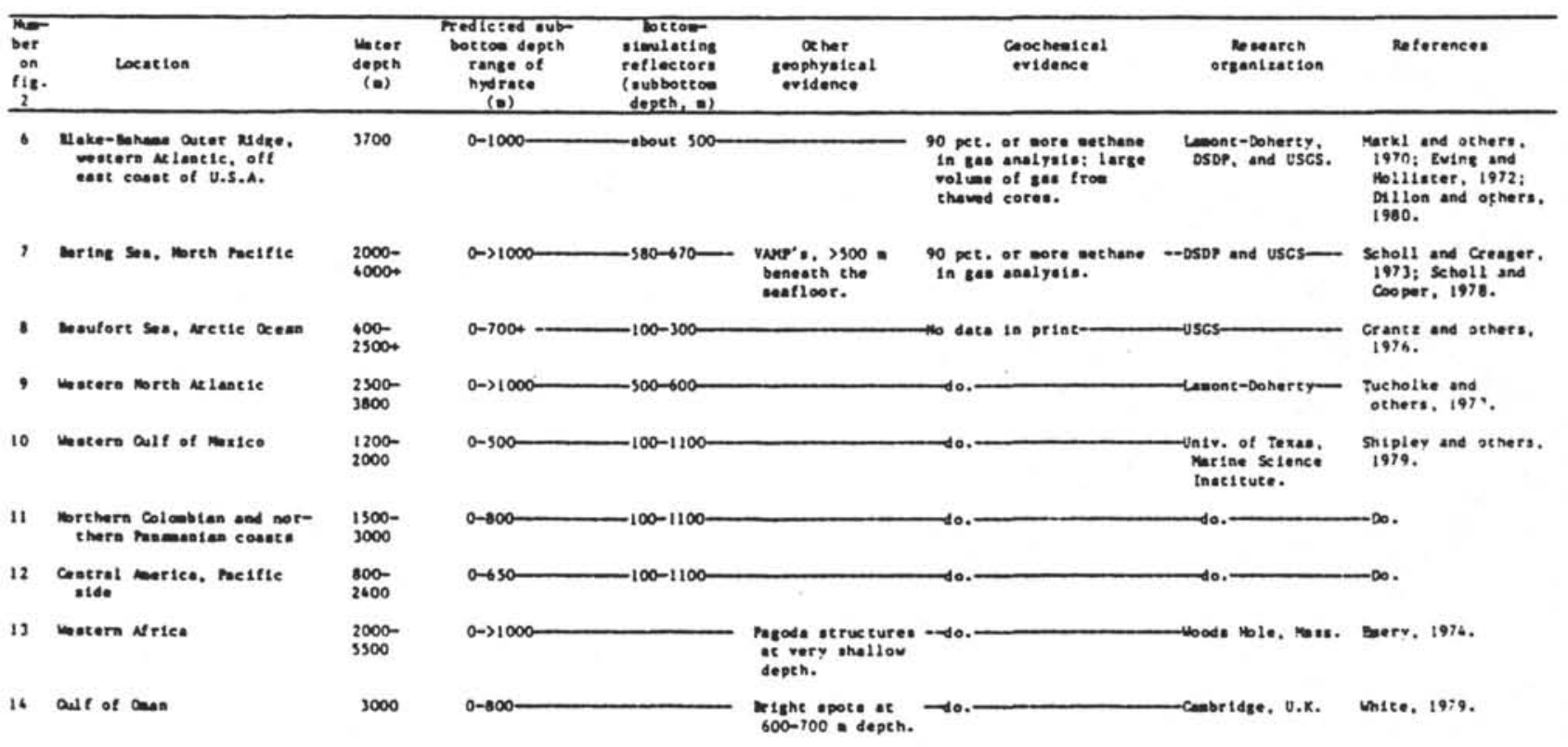


are generally characterized by reflection polarity reversals and large reflection coefficients (Sh1pley and others, 1979). Gas hydrate zones and diagenetic boundaries in sediment have been proposed as possible causes of these anomalous seismic reflectors.

Before DSDP Leg 11 in the Blake-Bahama region of the Atlantic Ocean, geophysicists of the Lamont-Doherty Geological Observatory were intrigued by bottom-simulating reflectors on their seismic records over the Blake-Bahama outer Ridge (Markl and others, 1970; Stoll and others, 1971). The observation that some of the seismic reflectors on their records intersected other reflectors and paralleled the seafloor (fig. 5) was unexplained. One of the major objectives of Leg 11 was to investigate the nature of the bottom-simulating reflectors and determine their relation, if any, to accumulations of gas hydrate beneath the seafloor. The strongest reflector on the ridge mimicked the ridge profile at a depth of more than $500 \mathrm{~m}$ below the seafloor. Samples from Sites 102, 103, and 104 of Leg 11 yielded mainly methane and traces of ethane (for quantitative gas composition data see Claypool and others, 1973). The strong bottom-simulating reflector was at that time correlated with a distinct break in the drilling rate and with a zone of nodules of siderite and ankerite (Lancelot and Ewing, 1972). Another explanation, suggested by Stoll, Ewing, and Bryan (1971), Ewing and Hollister (1972), and Dillon, Grow, and Paull (1980), is that the bottom-simulating reflector corresponds to the isotherm that separates a gas enviroment from a gas hydrate enviroment. The average thermal gradient for the ridge (about 35$40^{\circ} \mathrm{C} / \mathrm{km}$ ) permits a gas hydrate to exist at the $500 \rightarrow$ sediment depth of the strong reflector, but below that level the temperature would be high

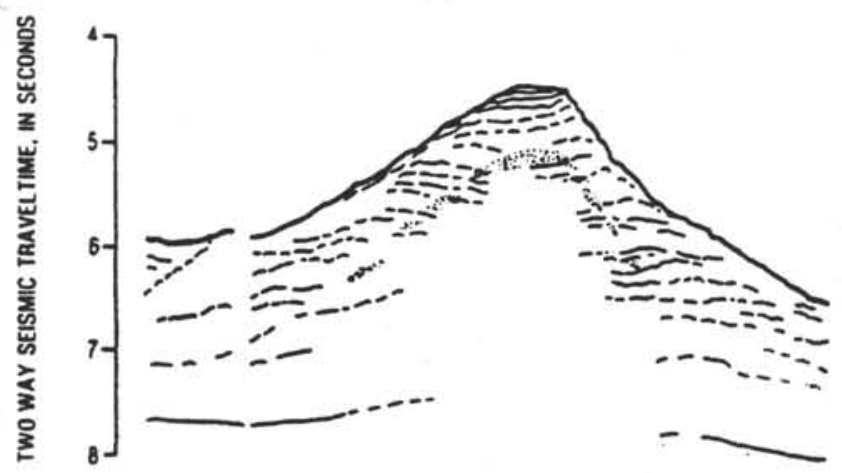

:50 100 KILOMETERS

Figure 5.--Diagramatic selemic profile of BlakeBahama Outer Ridge, showing thin, regularly spaced reflectors from strata. Bottom-simulating reflector (stippled) transects bedding and parallels seafloor and may represent hydrate-to-free-gas transition at bottom of gas hydrate zone. Redrawn from Tucholke and others (1977). enough that methane could exist only as a gas. The Interface between gas hydrate above and free gas below could provide a velocity contrast that is responsible for the bottom-simulating reflector. Furthermore, the apparent acoustic velocity through sediment overlying this reflector was determined to be about $2 \mathrm{~km} / \mathrm{s}$ (Lancelot and $E w-$ ing, 1972). This value, later confirmed by independent sonobuoy measurements (Bryan, 1974), 1s unusually high for hemipelagic sediment.

Laboratory experimental studies provide further evidence linking gas hydrates with the sediments of the Blake-Bahama Ridge. Stoll, Ewing, and Bryan (1971) demonstrated that when methane mixed with water-saturated sand was brought to the estimated temperatures and pressures of the Blake-Bahama Ridge sediment, the velocity of compressional seismic waves in the sand increased from 1.7 to $2.5 \mathrm{~km} / \mathrm{s}$. This experimental increase in seismic velocity helps explain the unusually high velocities observed in hemipelagic sediment of the ridge.

Since they were first found in the BlakeBahama Ridge (Markl and others, 1970; Ewing and Hollister, 1972), other bottom-simulating reflectors have been reported ( $f 1 g .3$ ) from the western North Atlantic Ocean (Tucholke and others, 1977), the Beaufort Sea of the Arctic Ocean (Grantz and others, 1976), and the Bering Sea and elsewhere in the North Pacific Ocean (Scholl and Creager, 1973). Shipley and others (1979) described bottom-simulating reflectors in sediments off the east coast of the United States, in the western Gulf of Mexico, off the northern coasts of colombla and Panama, and along the Pacific coast of Central America from Panama to Acapulco, Mexico. From studies of the western North Atlantic, Tucholke, Bryan, and Ewing (1977) 1dentified two high-amplitude reflecting horizons that are conformable with the seafloor and about 500 to $600 \mathrm{~m}$ beneath it. These horizons show the following characteristics: they cut across bedding-plane reflectors in the same manner as the reflector horizon observed on the Blake-Bahama Ridge; they appear to be restricted to areas where sedimentary strata dip landward; and their subbottom depth increases with the seafloor depth, a relation consistent with theoretical predictions of the configuration of a hydrate zone (fig. 4). A zone of gas hydrates may overlie the anomalous horlzons, and thus the seisalc horizons could be reflectors representing as impedance contrast caused by the downward change from gas hydrate to gas in the sediment. Grantz and others (1976) identified a strong seismic reflector that mimics the bathymetry of the seafloor, 100-300 m beneath $1 t$, on the continental slope of the Beaufort Sea north of Alaska. The bottom-simulating reflector was identified in about 60 percent of seismic profiles obtained in water deeper than 400-600 m. Not all bottom-simulating reflectors can be directly related to the presence of gas hydrates. Although gas hydrates provide one reasonable explanation for bottom-simulating reflectors, these acoust1c features may also result from temperature controlled dlagenetic effects. Dur- 
Ing DSDP Leg 19, Scholl and Creager (1973) noted seismic reflectors that tend to parallel the seafloor in some Bering Sea sediments draped on the Umnak Plateau, and they colned the acronym BSR for the bottom simulating reflector. At two sites, 184 and 185 , the reflector was penetrated. Although methane was observed in sediment from S1 te 185, no other evidence for gas hydrates was noted. Scholl and Creager (1973) attribute this reflector to a lithologic transition from hemipelagic diatom ooze to indurated claystone. Because of the time-transgressive nature of this horizon, this BSR appears to represent some sort of migratory diagenetic boundary related to the dissolution of diatoms and the formation of claystone. He in and others (1978) confirmed that opal-A is transformed to opal-CT in the temperature range corresponding to a subbottom depth of $600 \mathrm{~m}$, the depth of the BSR in Bering Sea sed1ment. Further, because the subbottom depth of the BSR on the flanks of Unnak Plateau decreases with increasing water depth, this BSR is probably not directly caused by gas hydrates (Shipley and others, 1979). Nevertheless, gas hydrates may st11l play an important role in the formation of this BSR. Claypool and Kaplan (1974) note that, in all cases of BSR's described from the Bering Sea, the lithologic change is consistent with the inferred depth of the isotherm where gas hydrate would decompose under the prevalling pressure conditions. Claypool and Kaplan (1974) suggest at least an indirect link between lithification and gas hydrate. Free carbon dioxide and methane concentrations determine the $\mathrm{pH}$ of interstitial water. The pH conditions determine the solubil1 ty of 11 thologic components such as carbonate and silica. Gas hydrate formation may influence carbon dioxide and methane activities and may therefore influence the dissolution and reprecipitation of carbonate and sil1ca cements.

Thus, some bottom-simulating reflectors are not directly related to the presence of gas hydrates, as 1llustrated above, but bottom-s1mulating reflectors may not be observed even though gas hydrates are present. For example, in areas where sedimentary stratification parallels the seafloor, the bottom-simulating reflector may not be detectable. During drilling on DSDP Leg 67 in the Mid-America Trench off Guatemala, gas hydrates apparently were encountered at S1 tes 497 and 498 , but the seismic records for these areas showed no obvious bottom-simulating reflectors (R. von Huene, oral commun., 1979).

Gas hydrate zones in the seafloor may form regionally extensive impermeable seals and may trap economically important accumulations of natural gas, provided sufficlent sources for methane are present. If gas were to migrate upward and be 1mpeded by hydrate, it would accumulate at the lower boundary of the hydrate zone as free gas and would cause a significant decrease in seismic velocity at that boundary (Bryan, 1974). Bottom-simulating reflectors are strongest in the vicinity of ridge crests and tend to fade out on the flanks (Markl and others, 1970), a configuration that suggests gas accumulation at the crest as in an anticlinal trap.

\section{OTHER SEISMIC EVIDENCE FOR GAS HYDRATES IN OCEANIC SEDIMENTS}

Seismic features other than bottom-simulating reflectors may be produced by gas hydraces. These features include bottow-parallel bright spots, pagoda structures, and deep-water velocity amplitude features (VAMP's). White (1977) suggested that seismic bright spots (amplitude anomalies) in the Gulf of Conan are caused by natural gas accumulations. These subbottom reflectors are curved, mimic the topography of the seafloor, and transgress local bedding (making these bright spots similar to bottom-simulating reflectors, but of lesser lateral extent). White (1979) 1nferred that the gas is held in place not by a stratigraphic trap but by an impermeable gas hydrate layer that follows the seafloor topography.

Emery (1974) has suggested that pagoda structures may be related to gas hydrates, although these are very shallow subbottom seismic features, and there is 11 trle consensus regarding their significance. Geophysical traverses across nearly flat mud bottom at depths between 2,000 and 5,000 m off western Africa provided extensive seismic shallow-penetration recordings at 3.5 $\mathrm{kHz}$. The recordings reveal the presence of common alternating light and dark triangular seismic features, or pagoda structures, whose internal structure and acoustic properties may, according to Enery (1974), be due to local centers of gas hydrate induration.

Velocity-amplitude features (VAMP's) are acoustic anomalles showing narrow ( 1 to $2 \mathrm{~km}$ ) subsurface columns of concave reflection horizons called pulldowns, associated with gently arched, high-amplitude horizons higher in the section (Scholl and Cooper, 1978). These kinds of acoustic anomalies, common on seismic profiles collected in the Bering Sea, are typically seen in flat-lying beds at subbottom depths greater than $500 \mathrm{~m}$ and in deep water around 4,000 m. VAMP's are essentially deep-seated "bright spots" underlain by reflection horizon pulldowns. Gas hydrates may be responsible for VAMP's by contributing to the restriction of upward-migrating gas and fluids.

It is difficult to detect gas hydrates by purely chemical and seisuic means. Support for the ddentification of gas hydrate in seafloor sediments will result when cores containing hydrates recovered at their subsea temperatures and pressures can be analyzed. A pressure core barrel capable of this task has been designed by DSDP but has never been successfully deployed in a gas hydrate horizon. From the geologic, geophysical, and geochemical evidence obtained thus far, there is little doubt that gas hydrates are an important part of the marine sedimentary record. 


\section{SELECTED BIBLIOGRAPHY}

The following is a selected bibliography containing the references cited in this paper along with other papers dealing with the physical chemistry, geology, and geophysics of gas hydrates. This bibliography does not represent an exhaustive search of the literature, but rather includes those pertinent papers readily available to us.

Baker, P.E., 1974, Experiments on hydrocarbon 8 as hydrates in unconsolidated sand, in Kaplan, I.R., ed., Natural gases in marine sediments: New York, Plenum, p. 227-234.

Barnes, R.O., and Coldberg, E.D., 1976, Me thane production and consumption in anoxic marine sediments: Geology, v. 4, p. 297-300.

Barnes, W.C., 1975, Sone structural implications of gas hydrates in deep-ocean sediments: Geological Society of America Abstracts with Programs, v. 7, p. 989-999.

Barrer, R.M., and Stuart, W.I., 1957, Non-stoichiometric clathrate compounds of water: Proceedings of the Royal Society of London, Ser. A, v. 243 , no. 1233 , p. 172-189.

Bily, C., and Dick, J.W.L., 1974, Naturally occurring gas hydrates in the Mackenzie Delta, N.h.T.: Bulletin of Canadian Petroleum Geology, v. 22, p. 320-352.

Brown, J.F., Jr., 1962, Inclusion compounds: Scientific American, v. 207, no. 1, p. 82-92.

Bryan, G.M., 1974, In situ indications of gas hydrates, in Kaplan, I.R., ed., Natural gases in marine sediments: New York, Plenum, $p$. 299-308.

Buffler, R.T., Shaub, F.J., Watkins, J.S., and Worzel, J.L., 1979, Anatomy of the Mexican ridges, southwestern Gulf of Mexico, in Watkins, J.S., Montadert, L., and Dickerson, P.W., eds., Geological and geophysical investigations of the continental margins: American As sociation of Petroleum Geologists Memoir No. 29 , p. 319-327.

Carson, D.B., and Katz, D.L., 1942, Natural gas hydrates: Petroleum Transactions of the American Institute of Mining Englneers, v. 146, p. 150-158.

Chan, J.P., and Giauque, W.F., 1964, The entropy of $\mathrm{NH}_{3} \cdot 2 \mathrm{H}_{2} \mathrm{O}$ : Heat capacity from 15 to $300^{\circ} \mathrm{K}$ : Journal of Physical Chemistry, v. 68, p. 30533057 .

Claussen, W.F., 195la, Suggested structures of water in inert gas hydrates: Journal of Chemical Physics, v.19, p. 259-260. 1951b, Erratum: Suggested structures of water in inert gas hydrate: Journal of Chemical Physics, v. 19, p. 662.

1951c, A second water structure for inert gas hydrates: Journal of Chemical Physics, v. 19 , p. 1425-1426.

Claypool, G.E., and Kaplan, I.R., 1974, The ori8 in and distribution of methane in marine sediments, in Kaplan, I.R., ed., Natural gases in marine sediments: New York, Plenum, p. 99139.

Claypool, G.E., Presley, B.J., and Kaplan, I.R., 1973, Gas analysis in sediment samples from Legs $10,11,13,14,15,18$, and 19 , in Creager, J.S., Scholl, D.W., and others, Initial reports of the Deep Sea Drilling Project, $v$. 19: U.S. Government Printing office, p. 879884 .

Cooper, A.K., Scholl, D.W., Marlow, M.S., Childs, J.R., Redden, G.D., Kvenvolden, K.A., and Stevenson, A.J., 1979, Hydrocarbon potential of the Aleutian Basin, Bering Sea: American Association of Petroleum Geologists Bulletin, v. 63, p. 2070-2087.

Creager, J.S., Scholl, D.W., and Supko, P.R., 1973, Introduction, in Creager, J.S., Scholl, D.W., and others, Initial reports of the Deep Sea Drilling Project, v. 19: U.S. Government Printing of fice, p. 3-16.

Culbertson, O.L., and MeKetta, J.J., Jr., 1951 , Phase equilibria in hydrocarbon-water systems III-the solubility of methane in water at pressures to 10,000 psia: Petroleum Transactions of the American Institute of Mining Engineers, v. 192, p. 23-226.

Davidson, D.W., 1971, The motion of guest molecules in clathrate hydrates: Canadian Journal of Chemistry, v. 42, p. 1224-1242.

1973, Clathrate hydrates, in Franks, Felix, ed., Water: A comprehensive treatise, v. 2: New York, Plenum, p. 115-234.

Davidson, D.W., El-Defrawy, M.K., Fuglem, M.0., and Judge, A.S., 1978, Natural gas hydrates in northern Canada: International Conference on Permafrost, 3d, Proceedings, v. 1, p. 937943.

Deaton, W.M., and Frost, E.M., Jr., 1948, Gas hydrates and their relation to the operation of natural-gas pipe lines: U.S. Bureau of Mines Monograph No. 8, $101 \mathrm{p}$.

D11lon, W.P., Grow, J.A., and Paull, C.K., 1980, Unconventional gas hydrate seals may trap gas off southeast U.S.: Orl and Gas Journal, v. 78 , no. 1 , p. $124-130$. 
Emery, K.0., 1974, Pagoda structures in marine sediments, in Kaplan, I.R., ed., Natural gases in marine sediments: New York, Plenum, p. 309-317.

Emery, K.0., and Hoggan, D., 1958, Gases in marine sediments: American Association of Petroleum Geologists Bulletin, v. 42, P. 2174-2188.

Enns, T., Scholander, P.F., and Bradstreet, E.D. 1965, Ef fect of hydrostatic pressure on gases dissolved in water: Journal of Physical Chemistry, v. 69, p. 389-391.

Evrenos, A.I., Heathman, J., and Ralst1n, J., 1971, Impermeation of porous media by forming hydrates in situ: Journal of Petroleum Technology, v. 23, p. 1059-1066.

Ewing, J.I., Ewing, Maurice, and Leyden, R., 1966, Se1smic-profiler survey of the Blake Plateau: merican Association of Petroleum Geologists Bulletin, v. 50, p. 1948-1971.

Ewing, J.I., and Hollister, C.H., 1972, Regional aspects of deep sea drilling in the western North Atlantic, 1n Hollister, C.H., Ewing, J.I., and others, Initial reports of the Deep Sea Drilling Project, v. 11: U.S. Government Printing of f1ce, p. 951-973.

Frost, E.M., Jr., and Deaton, W.M., 1946, Gas hydrate composition and equilibrium data: orl and Gas Journal, v. 45, no. 12, p. 170-178.

Garg, S.K., and Davidson, D.W., 1973, N.M.R. properties of clathrate 1ce, in Whalley, E., Jones, S.J., and Gold, L.W., eds., Physics and chemistry of 1ce: Ottawa, Royal Soclety of Canada, p. 56-60.

Gas Supply Committee, 1979, Gas from natural gas hydrates: Gas energy review, American Gas Association, v. 7 , no. 10 , p. 1-5.

Geotimes, 1979a, Middle American Trench: v. 24, no. 9, p. 20-22.

Geotimes, 1979b, The Caribbean connection, v. 24 , no. 12 , p. $18-19$.

Glew, D.N., 1962, Aqueous solubility and the gas-hydrates; The methane-water system: Journal of Physical Chemistry, v. 66, p. 605609.

cold, L.W., and Lachenbruch, A.H., 1973, Thermal conditions in permafrost--A review of North merican 11terature, in Permafrost--The North American contribution, 2nd International Conference: Washington, National Academy of Sciences, p. 3-23.
Cordberg, Paul, 1963, Free radicals and reactive molecules in clathrate cavities: Science, $v$. 142 , p. 378-379.

Grantz, Arthur, Boucher, G.W., and Whitney, O.T., 1976, Possible solid gas hydrate and natural gas deposits beneath the continental slope of the Beaufort Sea: U.S. Geological Survey Circular 733, p. 17.

Hagan, M.M., 1962, Clathrate inclusion compounds: New York, Van Nostrand-Reinhold, 189 p.

Hampton, Loyd, ed., 1974, Physics of sound in marine sediments: New York, Plenum, 567 p.

Hand, J.H., Katz, D.L., and Verma, V.K., 1974, Review of gas hydrates with implication for ocean sediments, 1n Kaplan, I.R., ed., Natural gases in marlne sediments: New York, Plenum, p. 179-194.

Hedberg, H.D., 1974, Relation of methane generation to undercompacted shales, shale dlapirs. and mud volcanoes: American Association of Petroleum Geologists Bullet1n, v. 58, p. 661673.

He In, J.R., Scholl, D.W., Barron, J.A., Jones, M.G., and Miller, J., 1978, Diagenesis of late Cenozoic diatomaceous deposits and formation of the bottom simulating reflector in the southern Bering Sea: Sedimentology, v. 25, p. 155-181.

Hitchon, B., 1974, Occurrence of natural gas hydrates in sedimentary basins, in Kaplan, I.R., ed., Natural gases in marine sediments: New York, Plenum, p. 195-225.

Hodgson, Bryan, 1978, Natural gas: The search goes on: National Geographic Magazine, v. 154 , P. 632-651.

Holder, G.G., Katz, D.L., and Hand, J.H., 1976, Hydrate formation in subsurface enviroments: American Association of Petroleum Geologists Bulletin, v. 60 , p. 981-984.

Holl1ster, C.D., Ewing, J.I., and others, 1972, Sites 102-103-104--Blake-Bahama Outer Ridge (northern end), In Hollister, C.D., Ewing, J.I., and others, Initial reports of the Deep Sea Drilling Project, v. 11: U.S. Government Printing office, p. 135-143.

Howitt, Frank, 1971, Permafrost geology at Prudhoe Bay: World Petroleum, v. 42, no. 8, p. 28-32 and 37-38.

kunt, J.M., 1979, Methane hydrates, in Hunt, J.M., Petroleum geochemistry and geology: San Franc1sco, W.H. Freeman, p. 156-162.

Jeffrey, G.A., 1969, Water structure in organic hydrates: Accounts of Chemical Research, v, 2, p. $344-352$. 
Jeffrey, G.A., 1972, Pentagonal dodecahedral water structure in crystalline hydrates: Material Research Bulletin, v. 7, p. 1259-1269.

Jeffrey, G.A., and McMullin, R.K., 1967, The clathrate hydrates: Progress in Inorganic Chemistry, v. 8, p. 43-108.

Thaveri, Jaysukh, and Robinson, D. B., 1965, Hydrates in the methane-nitrogen system: Canadian Journal of Chemical Engineering, v. 43, p. 75-78.

Judge, Al an, 1973, The prediction of permafrost thicknesses: Canadian Geotechnical Journal, v. $10, p \cdot 1-11$.

Kaplan, I.R., ed., 1974, Natural gases in marine sediments: New York, Plenum, 324 p.

Katz, D.L., 1945, Prediction of conditions for hydrate formation in natural gases: Petroleum Transactions of the American Institute of MinIng Engineers, v. 160, p. 140-149.

1971, Depths to which frozen gas fields (gas hydrates) may be expected: Journal of Petroleun Technology, v. 23, p. 419-423.

1972, Depths to which frozen gas fields may be expected--Footnotes: Journal of Petroleum Technology, v. 24, p. 557-558.

Katz, D.L., Cornel1, D., Kobayash1, R1k1, Poettmann, F.H., Vary, J.A., Elenblass, J.R., and Weinaug, C.F., 1959, Handbook of natural gas engineering: New York, McGraw-Hill, 802 p.

Kobayashi, Riki, and Ratz, D.L., 1949, Methane hydrate at high pressure: Petroleum Transactions of the American Institute of Mining Engineers, v. 185, p. 66-70.

Lancelot, Y., and Ewing, J.I., 1972, Correlation of natural gas zonation and carbonate diagenesis in Tertiary sediments from the north-west Atlantic, in Hollister, C.D., Ewing, J.I., and others, Intrial reports of the Deep Sea Dril11ng Project, v. 11: U.S. Government Printing office, p. 791-799.

Langseth, M.G., Jr., and von Herzen, R.P., 1970, Beat flow through the floors of the oceans, in Maxwel1, A.E., ed., The sea, v. 4: New York, w1ley-Interscience, p. 299-352.

Makogon, Yu. F., Trebin, F.A., Trofimuk, A.A., Tsarev, V.P., and Cherskiy, N.v., 1971, Cbnarvihen1ye zalezh1 prirodnogo gaza v trertom (gazogldratnom) sostoyan11 ["Detection of a pool of natural gas in a solld (hydrated gas) state"]: Doklady Akadem11 Nauk SSSR, v. 196, p. 203-206 (1n Russian); Doklady-Earth Science Section 196 (1972), p. 197-200 (in Engl1sh).
Makogon, Yu. F., Trofimuk, A.A., Tsarev, V.P. and Cherskiy, N.V., 1973, Vozmozhnosti obrazovaniya gazogidratnykh zalezhey prirodnykh gazov $v$ pridonnoy zone morey 1 okeanov ["Possible origin of natural gas hydrates at floors of seas and oceans"]: Akademiya Nauk SSSR Sibirskoye Otdeleniye Geologiya 1 Geofizika, no. 4, p. 3-6 (in Russian); International Geology Review, v. 16 (1974), p. 553-556 (in English).

Makogon, Yu. F., Tsarev, V.I., and Chersky, N.V., 1972, K voprosu formirovan1ya krupnykh mestorozhdenfy gaza $v$ zonakh pasprostraneniya ponizhennykh temperatur ["Formation of large natural gas fields in zones of permanently low temperatures"]: Doklady Akademii Nauk SSSR, v. 205, p. 700-703 (1n Russian); Doklady-Earth icience Section 205 (1973), p. 215-218 (in inglish).

Mandelcorn, Lyon, 1959, Clathrates: Chemical leviews, v. 59, p. 827-839.

Markl, R.G., Bryan, G.M., and Ewing, J.I., 1970, Structure of the Blake-Bahama Outer Ridge: Journal of Geophysical Research, v. 75, p. 4539-4555.

Marshall, D.R., Sa1to, S., and Kobayash1, Rik1, 1964, Hydrates at high pressure: I. Methane-water, argon-water, and n1trogen-water systems: American Institute of Chemical Engineers Journal, v. 10, p. 202-205.

McIver, R.D., 1973, Hydrocarbons in canned muds from sites $185,186,189$, and 191-Leg 19,1 in Creager, J.S., Scholl, D.W., and others, Initial reports of the Deep Sea Drilling Project, v. 19: U.S. Goverment Printing office, p. 875-877.

1974, Hydrocarbon gas (methane) in canned Deep Sea Drilling Project core samples, in Kaplan, I.R., ed., Natural gases in marine sediments: New York, Plenum, p. 63-69.

1977, Hydrates of natural gas--Important agent in geologic processes: Geological Soc1ety of America Abstracts with Programs, v. 9, p. 1089-1090.

Miller, S.L., 1974, The nature and occurrence of clathrate hydrates, in Kaplan, I.R., ed., Natural gases in marine sediments: New York, Plenum, P. 151-177.

Milton, D.J., 1976, Methane hydrate in the seafloor--A significant resource? In Meyer, $R$. F., ed., The future supply of nature-made petroleum and gas technical reports: New York, Pergamon, p. 927-943.

Noaker, L.J., and Katz, D.L., 1954, Gas hydrates of hydrogen sulfide-methane mixtures: Petroleum Transactions of the American Inst1tute of Mining Engineers, v. 201, p. 237-239. 
O1l and Gas Journal, 1978, Soviets mull counting gas hydrates in fuel reserves: 011 and Gas Journal, v. 76 , no. 43 , p. 63 .

Parrish, W.R., and Prausnitz, J.M., 1972, Dissoclation pressures of gas hydrates formed by gas mixtures: Industrial and Engineering Chemistry, Process Design and Development, v. 11, P. 26-35.

Pena, Jorge, and de Pena, R.G., 1970, Freezing temperatures of water droplets $n$ equilibrium with different gases: Journal of Geophysical Research, v. 75, p. 2831-2335.

PIchon, Y.L., Ewing, J.I., and Houtz, R.E., 1968, Deep-sea sediment velocity determinations made while reflection profiling: Journal of Geophysical Research, v. 73, p. 2597-2614.

Ratcliffe, E.H., 1960, The thermal conductivities of ocean sediments: Journal of Geophysical Research, v. 65, p. 1535-1541.

Robinson, D.B., and Hutton, J.M., 1967, Hydrate formation in systems contalning methane, hydrogen sulfide, and carbon dioxide: Journal of Canadian Petroleum Technology, v. 6, p. 69.

Savit, C.H., 1974, Bright spot in the energy picture: Ocean Industry, v. 9, no. 2, p. 6065.

Schol1, D.W., and Cooper, A.K., 1978, VAMPs-Possible hydrocarbon-bearing structures in Bering Sea basin: American Association of Petroleum Geologists Bulletin, v. 62, p. 24812488.

Scholl, D.W., and Creager, J.S., 1973, Geologic synthesis of Leg 19 (DSDP) results: Far north Pacific, and Aleutian Ridge, and Bering Sea, In Creager, J.S., Scholl, D.W., and others, Initial reports of the Deep Sea Drilling Project, v. 19: U.S. Government Printing Office, p. $897-913$.

Shipley, T.H., Buffler, R.T., and Warkins, J.S., 1978, Selsmic stratigraphy and geologic history of the Blake Plateau and adjacent western Atlantic continental margin: American Association Petroleum Geologists Bulletin, v. 62, p. 792-812.

Shipley, T.H., Houston, M.H., Buffler, R.T., Shaub, F.J., McM1llen, K.J., Ladd, J.W., and Worzel, J.L., 1979, Selsmic reflection evidence for the widespread occurrence of possible gas-hydrate horizons on continental slopes and rises: American Association of Petroleum Geologists Bulletin, v. 63, p. 22042213.
Sheriff, R.E., 1975, Factors affecting seismic amplitudes: Geophysical Prospecting, v. 23, p. 125-138.

Sto11, R.D., 1974a, Acoust1c waves in saturated sediments, in Hampton, Lyd, ed., Physics of sound in marine sediments: New York, Plenum, p. 19-39.

,1974b, Effects of gas hydrates in sediments, In Kaplan, I.R., ed., Natural gases in marine sediments: New York, Plenum, p. 235248.

Stoll, R.D., and Bryan, G.M., 1979, Physical properties of sediments containing gas hydrates: Journal of Geophysical Research, $v$. 84, p. 1629-1634.

Stol1, R.D., Ewing, J.I., and Bryan, G.M., 1971, Anomalous wave velocities in sediments containing gas hydrates: Journal of Geophysical Research, v. 76, p. 2090-2094.

Takenouch1, S., and Kennedy, G.C., 1965, D1ssociation pressures of the phase $\mathrm{CO}_{2}{ }^{-5} 3 / 4$ $\mathrm{H}_{2} \mathrm{O}$ : Journal of Geology, v. 73, p. $383-390$.

Tucholke, B.E., Bryan, G.M., and Ewing, J.I., 1977, Gas-hydrate horizons detected in seismic-profiler data from the western North Atlantic: American Association of Petroleum Geologists Bulletin, v. 61, p. 698-707.

Trofimuk, A.A., Cherskiy, N.V., and Tsarev, V.P., 1973, Osobennosti nakopleniya prirodnykh gosov v zonakh gidratoobrazovaniya Mil rovogo okeana ["Accumulation of natural gases in zones of hydrate-formation in the hydrosphere"]: Doklady Akadem11 Nauk SSSR, v. 212, p. 931-934 (1n Russ1an); Doklady-Earth Science Section 212 (1974), p. 87-90 (1n Engl1sh).

Unruh, C.H., and Katz, D.L., 1949, Gas hydrates of carbon dioxide-methane mixtures: Petroleum Transactions of the American Institute of MinIng Engineers, v. 186, p. 83-86.

White, R.S., 1977, Selsmic bright spots in the Gulf of Onan: Earth and Planetary Sclence Letters, v. 37, p. 29-37.

1979, Gas hydrate layers trapping free gas in the Gulf of Onan: Earth and Planetary Sc1ence Letters, v. 42, p. 114-120.

Yefremova, A.G., and Zhizhchenko, B.P., 1974, Obnaruzheniye kristall-gidradov gazov v osadkakh sovremennykh akvatoriy ["Occurrence of crystal hydrates of gases in the sediments of modern marine basins"]: Doklady Akadem11 Nauk SSSR, v. 214, p. 1179-1181 (in Russian); Doklady-Earth Sclence Section 214 (1975), p. 219220 (1n English). 